CAMILA FREITAS BATISTA

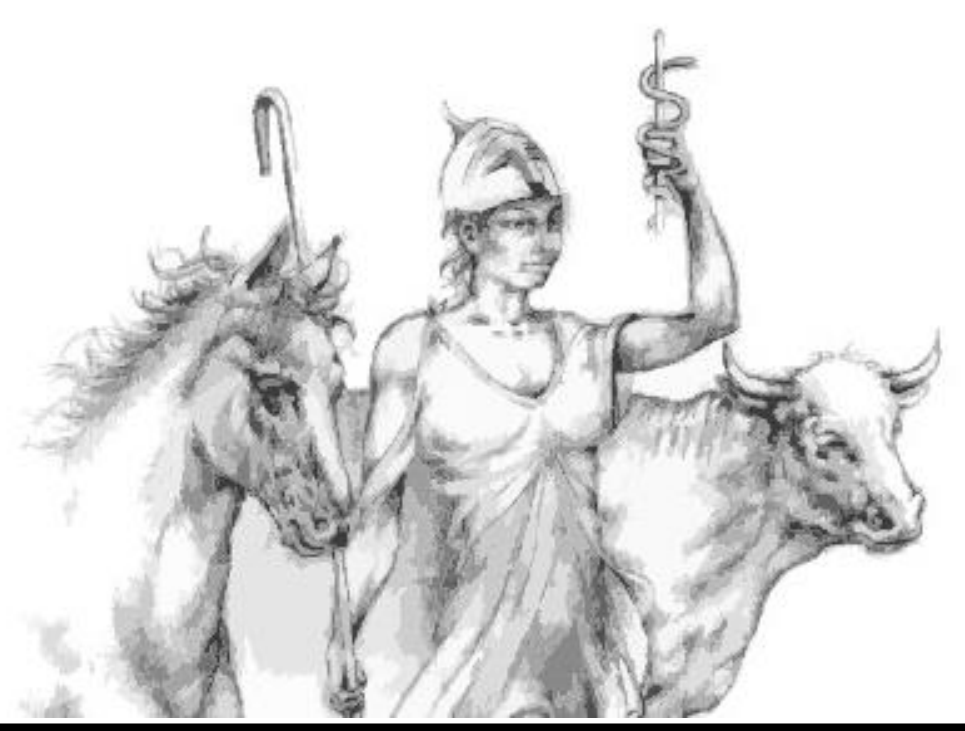

\title{
Dinâmica de fagócitos sanguíneos e alveolares em bezerros com mannheimiose
}

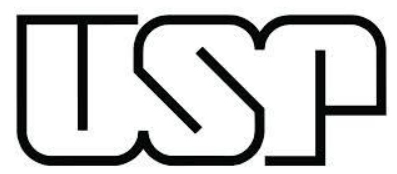

São Paulo 2015 
Dinâmica de fagócitos sanguíneos e alveolares em bezerros com mannheimiose

Tese apresentada ao Programa de PósGraduação em Clínica Veterinária da Faculdade de Medicina Veterinária e Zootecnia da Universidade de São Paulo para obtenção do título de Doutor em Ciências

\section{Departamento:}

Clínica Médica

\section{Área de Concentração:}

Clínica Veterinária

\section{Orientadora:}

Prof ${ }^{a}$ Dr $^{\mathrm{a}}$ Alice Maria Melville Paiva Della

Libera

De acordo:

$$
\text { Orientador(a) }
$$

\section{São Paulo}

2015 
Autorizo a reprodução parcial ou total desta obra, para fins acadêmicos, desde que citada a fonte.

\section{DADOS INTERNACIONAIS DE CATALOGAÇÃO-NA-PUBLICAÇÃO}

\section{(Biblioteca Virginie Buff D' Apice da Faculdade de Medicins Veterintria o Zootecain da} Univerridado de SIs Pralo)

T.3203 Bateta, Camlia Frelas

FMNZ Dinsmica de fagoclios aspulneos e alveolares em bezertos com marrheimlose ! Camila Freitas Eatista. -2015

$145 \mathrm{t}: \mathrm{I}$.

Tese (Doutorado) - Univerzidade de S\$o Faulo. Faculdade de Medicina Veteringrta e Zoctecnla. Departamento de Cirica Medica, s5o Paulo, 2015.

Frograma de Fos-Graduaçlox Cirica Veterinaria.

Area de concentraç5o: Clinica Veterinaria.

Orientador. Prof - De. Alce Maria Melvile Patra Dela Ubera.

1. Bovinos. 2 Mannheimla haemolytica. 3. Pneumonia. 4. Lavado broncoalveolar. 5. Resposta imune. L. Thulo. 


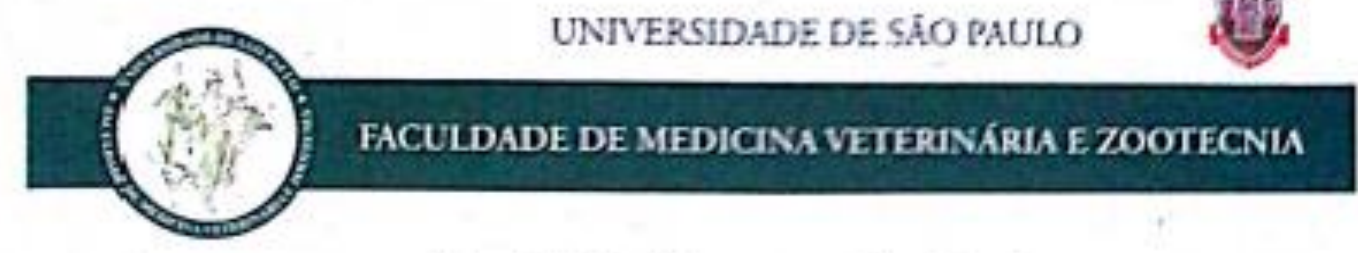

\section{Comissāo de Ética no uso de animais}

\section{CERTIFICADO}

Certificamos que o Projeto intitulado "Avaliaçăo da dinámica de fagócitos na mannheimiose em bezerros", protocolado sob o $\mathrm{n}^{\circ}$ 2436/2011, utilizando 12 (doze) bovinos, sob a responsabilidade do(a) Profa. Dra. Alice Maria Melville Paiva Della Libera, está de acordo com os principios éticos de experimentaçăo animal da "Comissióo de Ética no uso de animais" da Faculdade de Medicina Veterinária e Zootecnia da Universidade de Săo Paulo e foi aprovado em reuniăo de $26 / 10 / 2011$.

We certify that the Research "Evaluation of dynamics of the phagocytes in calves with infection for Mannheimia", protocol number 2436/2011, utilizing 12 (twelve) cattle, under the responsibility Profa. Dra. Alice Maria Melville Paiva Della Libera, agree with Ethical Principles in Animal Research adopted by "Ethic Committee in the use of animals" of the School of Veterinary Medicine and Animal Science of University of Sĩo Paulo and was approved in the meeting of day $10 / 26 / 2011$.

São Paulo, 27 de outubro de 2011.

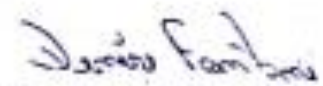

Denise Tabacchi Fantoni

Presidente 


\section{FOLHA DE AVALIAÇÃO}

Nome: Batista, Camila Freitas

Título: Dinâmica de fagócitos sanguíneos e alveolares em bezerros com mannheimiose

Tese apresentada ao Programa de Pós-Graduação em Clínica Veterinária da Faculdade de Medicina Veterinária e Zootecnia da Universidade de São Paulo para obtenção do título de Doutor em Ciências

Data:

\section{Banca Examinadora}

Prof. Dr.

Instituição:

Julgamento:

Prof. Dr.

Instituição: Julgamento:

Prof. Dr.

Instituição: Julgamento:

Prof. Dr.

Instituição: Julgamento:

Prof. Dr.

Instituição: Julgamento: 
"Aqueles que passam por nós, não vão sós, não nos deixam sós. Deixam um pouco de si, levam um pouco de nós" Antoine de Saint-Exupéry 


\section{DEDICATÓRIA}

À minha mãe Lidia, que SEMPRE me apoiou e $\mathcal{N} U \mathcal{N} C \mathcal{A}$ questionou minhas escolhas

À minha grande familia (pai, irmãos, tías e tíos, primas e primos)

Em especial a Minha Tía MMIRA (in memorian) que acompanhou meu crescimento e era minha grande torcedora e incentivadora

Vocês SEMPRE TORCERAM e ACREDITARAM.

Os meus mais sinceros e profundos agradecimentos

Sem vocês isso não sería possivel 


\section{AGRADECIMENTO ESPECIAL}

À pessoa que me fez querer seguir esse caminho Que mostrou ser possivel ser mãe, esposa, fítha, neta e uma profíssional brilhante em uma única pessoa

Minha mentora, minha orientadora

Alice María Melville Paiva Della Líbera

Orientadora, professora, amiga, confidente, terapeuta Um exemplo de dedicação, carinho, afeto e profíssionalísmo

Agradeço por ter acreditado e investido em mim

Por fazer parte da minha vida

$\mathcal{E}$ por maís essa conquista

Muito Obrigada jamais será sufíciente 


\section{AGRADECIMENTOS}

A Deus

Que sempre permaneceu ao meu lado, me deu força para vencer as dificuldades e continuar lutando.

À minha família

Obrigada pelo amor, carinho, apoio e compreensão durante essa longa jornada.

\section{À Profa $\underline{a}$ Dra Alice Maria Melville Paiva Della Libera}

Minha Orientadora, que acreditou no meu trabalho e principalmente acreditou em mim.

Obrigada por ter me incentivado, por ter me mostrado o caminho, por nunca ter desistido, obrigada por cada conversa, cada bronca, cada conselho e por cada abraço. Nunca conseguirei agradecer à altura.

À equipe Della Libera, minha família científica

Maiara Garcia Blagitz, Heloisa Godoi Bertagnon, Fernando Nogueira Souza, Renata Caminha Gomes, Kamila Reis Santos, ]éssyca Beraldi Bellinazzi, Maria Gabriela Barbosa Lima gostaria de agradecer cada um individualmente, pelo companheirismo, pela amizade, pela ajuda, pela companhia, pelas risadas, pelas lágrimas, por cada minutinho que vocês dedicaram a mim. Sem vocês esse trabalho nunca teria terminado.

Aos alunos de iniciação científica Nicholas Vespa Del Bigio, Endrew Rodolfo Morais Martins e Paula Molinari

Pela ajuda, conversas e por mostrar que também sei ensinar.

Ao Prof. Dr. Fernando José Benesi

Pelas palavras carinhosas e aconchegantes, pelas broncas, pela convivência, por transmitir seus conhecimentos, por seu acolhimento paternal. Muito obrigada. 
Aos Prof. Dr. Marcos Bryan Heinemann e Prof. Dr. Andrey Pereira Lage

Por prepararem a protagonista desse projeto, a $M$. haemolytica.

Ao Prof. Dr. Roberto Calderón Gonçalves e a amiga M.V. Ms. Mayra Martins

Por fazerem parte desse projeto

Ao M.V. Ms. Ricardo Spacagna Jordão

Por ceder as instalações do Laboratório de Produção de lmunobiológicos para o preparo do inóculo e principalmente por ter sido um grande amigo durante esses anos.

Às meninas do laboratório

Clara Satsuki Mori, Marly Elizabete Ferreira de Castro, Maria Helena da Silva Pelissari, Samantha lve Miyashiro, Carmen Silvia Ribeiro, Edina Santana dos Santos, Creide Donizete Costa, por toda ajuda durante todos esses anos.

\section{À Claudia Regina Stricagnolo}

A minha querida Claudinéia, que sempre me ajudou e me apoiou, brigou e fez muito por mim, obrigada por tudo.

Às secretárias do Departamento de Clínica Médica

Silvana Rossi Guedes, Maria Aparecida de Freitas e Carolina Aroma pelo carinho e ajuda durante esses anos.

Aos Funcionários da Clínica de Bovinos e Pequenos Ruminantes

Luis Rodrigues, Edson Diogo, Francisco de Souza, Edilson Duque pela ajuda, pelo carinho, pelo cuidado com os animais. 
Ao Dr. Ermelindo Della Libera Junior

Que acreditou no trabalho e sempre me deu palavras de incentivo, obrigada pela ajuda e pelos ensinamentos.

Aos Médicos Veterinários residentes dos anos de 2011 a 2015

Arnaldo Sotero, Maíra Bianchi Rodrigues Alves e Vanessa Grosso, Ronaldo Gomes Gargano, Juliana Bombardelli, Loraine Fernandes, Rodrigo Malzoni de Sousa, Camila Martin, Marcela Romanini Faria, Gabriela Alves Reis, Mailson Renan Dias, Joel Ferreira, Elisa Weiss, Giuliana Manchini, Adriano Debiazzi, Deisiane Murta Nobre, lzabelle Oliveira e Pedro Bernardino Müller pela ajuda durante o projeto, pelo carinho, colaboração e momentos muito agradáveis.

Ao Dr. Philip Griebel e a Dra. Patricia Cano-Gonzalez da University of Saskatchewan

Pela acolhida, pelos conhecimentos, pela simplicidade, pelo tempo dedicado a mim, sem palavras para agradecer.

À minha Amiga e lrmã Bruna Stefania Tadini

Que durante essa longa jornada dividiu muitos dias comigo, obrigada por me acompanhar, me ajudar, me ouvir, incentivar, por dar broncas, oferecer um ombro, por todas as horas de choro e de riso, alegrias e tristezas, pelos abraços e palavras de carinho, por fazer parte da minha vida. Muito, muito obrigada.

\section{À minha querida Amiga Daniela Soares Ferraz}

Que abriu sua casa para me acolher quando precisava de paz e silêncio, por ser essa grande amiga que me ajuda, incentiva, apoia, briga, chora, ri. Obrigada infinitamente.

À minha Amiga Lucila Oliveira Vilela

Que lá de longe me ofereceu ajuda, principalmente com o inglês, me ensinando uns truques da língua e traduzindo o resumo desta tese. 
Aos meus amigos do Esquadrão

Mariana Sequetin Cunha, Marina de Melo Del Grande, Marina Godoi Gimeno, Eduardo de Oliveira Pontes e Ana Letícia Gulin da Silva por estarem por perto durante essa longa caminhada, mesmo que não fosse fisicamente.

À Secretária da pós-graduação do Departamento de Clínica Médica Adelaide Fátima de Jesus Borges Por todo carinho, dedicação e ajuda durante essa fase.

Aos Professores do Departamento de Clínica Médica

Archivaldo Reche Junior, Carla Bargi Belli, Carlos Eduardo Larsson, Denise Saretta Schwartz, Enrico Lippi Ortolani, Fábio Celidônio Pogliani, Fernando José Benesi, Lilian Gregory, Marcia Gomes, Marcia Mery Kogika, Maria Helena Matiko Akao Larsson, Maria Claudia Araripe Sucupira, Mitika Kurubayashi Hagiwara, Raquel Yvonne Arantes Bacarin, Silvia Regina Ricci Lucas, Viviani Gomes e Wilson Roberto Fernandes, obrigada pelos ensinamentos e pela convivência.

Ao Colega M.V. Ms. Ronaldo Gomes Gargano

Por oferecer ajuda sempre que precisei, por virar as noites no hospital ajudando simplesmente por amar a profissão e gostar de ajudar os amigos. Você é um exemplo.

À Fundação de Amparo à Pesquisa do Estado de São Paulo (FAPESP)

Pelos financiamentos de bolsa (Processo $n^{\circ}$ 11/23936-6) e de auxílio à pesquisa (Processo $n^{\circ}$ 12/00749-9) que possibilitaram a realização desse trabalho.

Ao Prof. Dr. Marcio Garcia

Por ceder algumas cepas de $M$. haemolytica para o início do experimento 
Aos colegas de pós-graduação que foram inúmeros nesses quatro anos e fundamentais para meu desenvolvimento pessoal

Não quero por nomes para não esquecer ninguém, mas cada um tem um lugarzinho comigo. Obrigada pela convivência.

Ao Prof. Dr. José Jurandir Fagliari

Por ceder uma cepa de $M$. haemolytica e sugerir outros pesquisadores que poderiam ter a bactéria

Ao M.V. Ms. Thales Vecchiato

Por fornecer os antimicrobianos utilizados no estudo e por sempre torcer pelo trabalho 


\section{RESUMO}

BATISTA, C. F. Dinâmica de fagócitos sanguineos e alveolares em bezerros com mannheimiose. [Dynamics of blood and alveolar phagocytes in calves with mannheimiose] 2015. 145f. Tese (Doutorado em Ciências) - Faculdade de Medicina Veterinária e Zootecnia, Universidade de São Paulo, São Paulo, 2015.

A Mannheimia haemolytica é uma importante bactéria relacionada ao Complexo Doença Respiratória dos Bovinos e a essa atribui-se uma evolução para uma forma grave de pneumonia fibrinonecrótica. É considerada um habitante comensal da nasofaringe que em situações de comprometimento da resposta imune adquire um perfil oportunista. O presente estudo buscou observar por meio de modelo de infecção experimental, as possíveis alterações locais e sistêmicas causadas pela $M$. haemolytica em bezerros experimentalmente inoculados. Dessa forma seria possível de maneira longitudinal, acompanhar a dinâmica dos principais aspectos de defesa das vias aéreas posteriores durante a infecção e após o tratamento com o antimicrobiano norfloxacina associado ou não à flunexina meglumina. Avaliou-se por exame físico acrescido de broncoscopia, alterações funcionais das células de defesa e mediadores inflamatórios, tanto séricos quanto locais e a atividade in vitro da norfloxacina sobre a função dos fagócitos sanguíneos e do lavado broncoalveolar (LBA). Para tal foram utilizados 12 bezerros sadios que foram experimentalmente infectados por $M$. haemolytica dos quais foram avaliadas as alterações clínicas e, quantitativamente e funcionalmente, as populações leucocitárias no sangue e no LBA, assim como o efeito da norfloxacina sobre a atividade funcional dos fagócitos no sangue e no LBA. Os resultados do presente estudo demonstraram o sucesso da infecção experimental por $M$. haemolytica pelos achados clínicos, broncoscópicos e citológicos. Ademais, a infecção experimental por $M$. haemolytica foi associada a alterações nas subpopulações de linfócitos $\mathrm{T} \mathrm{CD}^{+}$e $\gamma \delta$, na produção intracelular de espécies reativas de oxigênio (ERO), fagocitose e viabilidade pelas células $\mathrm{CD}_{1} 4^{+}$ sanguíneas e do LBA e granulócitos do sangue e, expressão de L-selectina pelos leucócitos polimorfonucleares do sangue. Nenhuma alteração evidente foi observada na expressão de citocinas IL-1 $\beta$, IL-8 e TNF- $\alpha$ nas células sanguíneas e do LBA. O tratamento com antimicrobiano associado ou não ao anti-inflamatório foi capaz de curar a infecção e reestabelecer os parâmetros avaliados à sua condição basal. Portanto, não se observou benefícios com a utilização adicional do anti-inflamatório no reestabelecimento do quadro clínico e da resposta imune neste experimento. Contudo, apesar de algumas alterações na 
resposta sistêmica durante o quadro infeccioso, as alterações locais foram mais perceptíveis. Outro aspecto importante encontrado foi o efeito in vitro da norfloxacina na produção intracelular de ERO, fagocitose bacteriana pelas células $\mathrm{CD} 14^{+}$sanguíneas e do LBA e em leucócitos polimorfonucleares no sangue. Conclui-se que as alterações funcionais dos fagócitos apresentaram papel importante na patogenia da mannheimiose, que foram condizentes com os achados clínicos da mannheimiose e da evolução do tratamento quando realizado no início do processo nosológico.

Palavras-chave: Bovinos. Mannheimia haemolytica. Pneumonia. Lavado broncoalveolar. Resposta imune. 


\begin{abstract}
BATISTA, C. F. Dynamics of blood and alveolar phagocytes in calves with mannheimiose. [Dinâmica de fagócitos sanguíneos e alveolares em bezerros com mannheimiose] 2015. 145f. Tese (Doutorado em Ciências) - Faculdade de Medicina Veterinária e Zootecnia, Universidade de São Paulo, São Paulo, 2015.
\end{abstract}

Mannheimia haemolytica is an important bacterial pathogen associated with Bovine Respiratory Disease Complex (BRDC) and it is believed to be the predominant cause of the disease's evolution into a fibrinonecrotic pneumonia. A commensal inhabitant of the nasopharynx, $M$. haemolytica acts as an opportunist when host defenses are compromised. This study used an experimental infection model to investigate the possible local and systemic changes caused by $M$. haemolytica in inoculated calves. It sought to linearly follow the dynamics of the lower respiratory tract defense mechanisms, during the course of infection and after treatment with the antibacterial norfloxacin, which was administrated both with and without the anti-inflammatory flunixin meglumine. With clinical examination followed by bronchoscopy, this study evaluated the physiological modifications in defense cells and mediators of inflammation, and the in vitro influence of norfloxacin on phagocytes from the peripheral blood and Bronchoalveolar Lavage Fluid (BLF). Twelve (12) healthy calves were infected with $M$. haemolytica and posteriorly physically examined, and had samples of white cells from the peripheral blood and BLF analyzed for changes in count and physiology, further, the norfloxacin effect on phagocytes from the peripheral blood and BLF was also studied. The experimental infection proved itself to be successful based on clinical, bronchoscopic and cytological findings. Furthermore, the M. haemolytica experimental infection was associated with modifications in the subpopulations of lymphocytes $\mathrm{CD}^{+}$and $\gamma \delta \mathrm{T}$ cells, in intracellular production of Reactive Oxygen Species (ROS), viability and phagocytosis activity of $\mathrm{CD}_{1} 4^{+}$cells from the peripheral blood and BLF and granulocytes from the peripheral blood. No obvious change was observed in the expression of cytokines IL-1 $\beta$, IL-8 e TNF- $\alpha$ by cells from the peripheral blood or BLF. The treatment with the antibacterial agent, with or without the anti-inflammatory, was proved to be successful in curing the disease, thus, the addition of an anti-inflammatory was considered unnecessary to revert the clinical infection and in the immune response. Although there was a systemic response during the course of infection, the local response was more noticeable. Another key finding of the present study was the in vitro effect of norfloxacin on the intracellular 
production of ROS and on phagocytosis activity of $\mathrm{CD} 14^{+}$cells from the peripheral blood and BLF and granulocytes from the peripheral blood. In conclusion, the functional changes in phagocytes play an important role in the pathogenesis of pulmonary infection caused by $M$. haemolytica, as they were consistent with the clinical findings of mannheimiosis and with the treatment when it was administrated in the beginning of the infection.

Key words: Cattle. Mannheimia haemolytica. Pneumonia. Bronchoalveolar lavage. Immune response. 


\section{LISTA DE TABELAS}

Tabela 1 - Médias e erros padrão das funções vitais: temperatura retal, frequência de movimentos respiratórios e frequência de batimentos cardíacos de bezerros durante os quatro momentos da infecção experimental por $M$. haemolytica - São Paulo - 2014

Tabela 2 - Número de amostras com isolamento bacteriano por momento e por agente do lavado traqueobrônquico e do suabe nasal dos bezerros durante os quatro momentos da pesquisa - São Paulo - 2014

Tabela 3 - Médias e erros padrão dos componentes citológicos do lavado broncoalveolar de bezerros durante os quatro momentos da infecção experimental por Mannheimia haemolytica - São Paulo - 2014.

Tabela 4 - Medianas e intervalos de confiança das porcentagens de células mononucleares identificadas por citometria de fluxo no lavado broncoalveolar de bezerros durante os quatro momentos da infecção experimental por Mannheimia haemolytica - São Paulo - 2014

Tabela 5 - Medianas e intervalos de confiança das porcentagens de células $\mathrm{T}$ identificadas por citometria de fluxo no lavado broncoalveolar de bezerros durante os quatro momentos da infecção experimental por Mannheimia haemolytica - São Paulo - 2014

Tabela 6 - Valores medianos e dos intervalos de confiança das células CD14 ${ }^{+}$que produziram espécies reativas de oxigênio basal e intensidade de fluorescência em valores arbitrários no lavado broncoalveolar de bezerros durante os quatro momentos da infecção experimental por Mannheimia haemolytica - São Paulo - 2014

Tabela 7 - Valores medianos e dos intervalos de confiança das células CD14 ${ }^{+}$que produziram espécies reativas de oxigênio e intensidade de fluorescência em valores arbitrários no lavado broncoalveolar de bezerros estimulados por Mannheimia haemolytica durante os quatro momentos da infecção experimental por Mannheimia haemolytica - São Paulo - 2014

Tabela 8 - Valores medianos e dos intervalos de confiança das células CD14 ${ }^{+}$que produziram espécies reativas de oxigênio e intensidade de fluorescência em valores arbitrários no lavado broncoalveolar de bezerros estimulados por Staphylococcus aureus durante os quatro momentos da infecção experimental por Mannheimia haemolytica - São Paulo - 2014

Tabela 9 - Valores medianos e dos intervalos de das células $\mathrm{CD} 14^{+}$que produziram espécies reativas de oxigênio e intensidade de fluorescência em valores arbitrários no lavado broncoalveolar de bezerros estimulados por Escherichia coli durante os quatro momentos da infecção experimental por Mannheimia haemolytica - São Paulo - 2014.

Tabela 10 - Valores percentuais das medianas e dos intervalos de confiança da fagocitose de Mannheimia haemolytica e intensidade de fluorescência em 
valores arbitrários no lavado broncoalveolar de bezerros durante os quatro momentos da infecção experimental por Mannheimia haemolytica. São Paulo - 2014 .....

Tabela 11 - Valores percentuais das medianas e dos intervalos de confiança da fagocitose de Staphylococcus aureus e intensidade de fluorescência em valores arbitrários no LBA de bezerros durante os quatro momentos da infecção experimental por Mannheimia haemolytica - São Paulo - 2014

Tabela 12 - Valores percentuais das medianas e dos intervalos de confiança da fagocitose de Escherichia coli e intensidade de fluorescência em valores arbitrários no LBA de bezerros durante os quatro momentos da infecção experimental por Mannheimia haemolytica - São Paulo - 2014.

Tabela 13 - Valores médios e dos erros padrão das células $\mathrm{CD}_{14}{ }^{+}$em apoptose, necrose, apoptose e/ou necrose e viabilidade das mesmas no lavado broncoalveolar de bezerros durante os quatro momentos da infecção experimental por Mannheimia haemolytica - São Paulo - 2014.

Tabela 14 - Valores médios absolutos e erros padrão do leucograma de amostras de sangue de bezerros durante os quatro momentos da infecção experimental por Mannheimia haemolytica - São Paulo - 2014.

Tabela 15 - Medianas e intervalos de confiança das porcentagens de leucócitos mononucleares identificadas por citometria de fluxo no sangue de bezerros durante os quatro momentos da infecção experimental por Mannheimia haemolytica - São Paulo - 2014

Tabela 16 - Médias e erros padrão das porcentagens populacionais de granulócitos identificadas por citometria de fluxo no sangue de bezerros durante os quatro momentos da infecção experimental por Mannheimia haemolytica - São Paulo - 2014

Tabela 17 - Medianas e intervalos de confiança das porcentagens das subpopulações de linfócitos $\mathrm{T}$ identificadas por citometria de fluxo no sangue de bezerros durante os quatro momentos da infecção experimental por Mannheimia haemolytica - São Paulo - 2014

Tabela 18 - Médias e erros padrão das porcentagens de granulócitos $\mathrm{CH}_{138^{+}}$que expressaram CD62L identificadas por citometria de fluxo no sangue de bezerros durante os quatro momentos da infecção experimental por Mannheimia haemolytica - São Paulo - 2014

Tabela 19 - Valores medianos e dos intervalos de confiança da produção de espécies reativas de oxigênio basal e intensidade de fluorescência em valores arbitrários por células $\mathrm{CD}_{14}^{+}$no sangue de bezerros durante os quatro momentos da infecção experimental por Mannheimia haemolytica - São Paulo - 2014

Tabela 20 - Valores medianos e dos intervalos de confiança da produção de espécies reativas de oxigênio e intensidade de fluorescência em valores arbitrários 
por células $\mathrm{CD}_{14}^{+}$no sangue de bezerros estimulados por Mannheimia haemolytica durante os quatro momentos da infecção experimental por Mannheimia haemolytica - São Paulo - 2014

Tabela 21 - Valores medianos e dos intervalos de confiança da produção de espécies reativas de oxigênio e intensidade de fluorescência em valores arbitrários por células $\mathrm{CD}_{1}{ }^{+}$no sangue de bezerros estimulados por Staphylococcus aureus durante os quatro momentos da infecção experimental por Mannheimia haemolytica - São Paulo - 2014.

Tabela 22 - Valores percentuais das medianas e dos intervalos de confiança da produção de espécies reativas de oxigênio e intensidade de fluorescência em valores arbitrários por células $\mathrm{CD}_{14}^{+}$no sangue de bezerros estimulados por Escherichia coli durante os quatro momentos da infecção experimental por Mannheimia haemolytica - São Paulo - 2014

Tabela 23 - Valores medianos e dos intervalos de confiança da produção de espécies reativas de oxigênio basal e intensidade de fluorescência em valores arbitrários por células $\mathrm{CH}_{138^{+}}$no sangue de bezerros durante os quatro momentos da infecção experimental por Mannheimia haemolytica - São Paulo - 2014

Tabela 24 - Valores medianos e dos intervalos de confiança da produção de espécies reativas de oxigênio e intensidade de fluorescência em valores arbitrários por células granulocíticas no sangue de bezerros estimulados por Mannheimia haemolytica durante os quatro momentos da infecção experimental por Mannheimia haemolytica - São Paulo - 2014.

Tabela 25 - Valores medianos e dos intervalos de confiança da produção de espécies reativas de oxigênio e intensidade de fluorescência em valores arbitrários por células granulocíticas no sangue de bezerros estimulados por Staphylococcus aureus durante os quatro momentos da infecção experimental por Mannheimia haemolytica - São Paulo - 2014

Tabela 26 - Valores medianos e dos intervalos de confiança da produção de espécies reativas de oxigênio e intensidade de fluorescência em valores arbitrários por células granulocíticas no sangue de bezerros estimulados por Escherichia coli durante os quatro momentos da infecção experimental por Mannheimia haemolytica - São Paulo - 2014.

Tabela 27 - Valores medianos e dos intervalos de confiança das células CD14 ${ }^{+}$que fagocitaram Mannheimia haemolytica e intensidade de fluorescência em valores arbitrários no sangue de bezerros durante os quatro momentos da infecção experimental por Mannheimia haemolytica - São Paulo - 2014

Tabela 28 - Valores medianos e dos intervalos de confiança das células CD14 ${ }^{+}$que fagocitaram Staphylococcus aureus e intensidade de fluorescência em valores arbitrários no sangue de bezerros durante os quatro momentos da infecção experimental por Mannheimia haemolytica - São Paulo - 2014 
Tabela 29 - Valores medianos e dos intervalos de confiança das células CD14 ${ }^{+}$que fagocitaram Escherichia coli e intensidade de fluorescência em valores arbitrários no sangue de bezerros durante os quatro momentos da infecção experimental por Mannheimia haemolytica - São Paulo - 2014

Tabela 30 - Valores medianos e dos intervalos de confiança células $\mathrm{CH}_{138^{+}}$que fagocitaram Mannheimia haemolytica e intensidade de fluorescência em valores arbitrários no sangue de bezerros durante os quatro momentos da infecção experimental por Mannheimia haemolytica - São Paulo - 2014

Tabela 31 - Valores medianos e dos intervalos de confiança de células $\mathrm{CH} 138^{+}$que fagocitaram Staphylococcus aureus e intensidade de fluorescência em valores arbitrários no sangue de bezerros durante os quatro momentos da infecção experimental por Mannheimia haemolytica - São Paulo - 2014

Tabela 32 - Valores medianos e dos intervalos de confiança de células $\mathrm{CH} 138^{+}$que fagocitaram Escherichia coli e intensidade de fluorescência em valores arbitrários no sangue de bezerros durante os quatro momentos da infecção experimental por Mannheimia haemolytica - São Paulo - 2014

Tabela 33 - Valores percentuais das médias e dos erros padrão das células CD14 ${ }^{+} \mathrm{em}$ apoptose, necrose, apoptose e/ou necrose e viáveis no sangue de bezerros durante os quatro momentos da infecção experimental por Mannheimia haemolytica - São Paulo - 2014

Tabela 34 - Valores percentuais das médias e dos erros padrão das células $\mathrm{CH} 138^{+}$ em apoptose, necrose, apoptose e/ou necrose e viáveis no sangue de bezerros durante os quatro momentos da infecção experimental por Mannheimia haemolytica - São Paulo - 2014

Tabela 35 - Expressão das citocinas (medianas e intervalos de confiança) nas células do sangue periférico (razão entre mRNA citocinas- interleucina-1 $\beta$, interleucina- 8 e fator de necrose tumoral $\alpha$ em relação ao mRNA do gene referência - GAPDH) dos bezerros durante os quatro momentos da infecção experimental por Mannheimia haemolytica - São Paulo - 2014

Tabela 36 - Expressão das citocinas (Medianas e intervalos de confiança) das células do lavado broncoalveolar (razão entre mRNA citocinas- interleucina-1 $\beta$, interleucina- 8 e fator de necrose tumoral- $\alpha$ em relação ao mRNA do gene referência- GAPDH) dos bezerros durante os quatro momentos da infecção experimental por Mannheimia haemolytica - São Paulo - 2014

Tabela 37 - Efeito in vitro da norfloxacina sobre a porcentagem de células CD14 ${ }^{+}$ que produziram espécies reativas de oxigênio e intensidade de fluorescência (IMF) em valores arbitrários basal e estimulados por Mannheimia haemolytica, Staphylococcus aureus e Escherichia coli no lavado broncoalveolar de bezerros sadios - São Paulo - 2014 .....

Tabela 38 - Efeito in vitro da norfloxacina sobre a porcentagem de células CD14 ${ }^{+}$ que fagocitaram Mannheimia haemolytica, Staphylococcus aureus e Escherichia coli no LBA de bezerros sadios - São Paulo - 2014 
Tabela 39 - Efeito in vitro da Norfloxacina sobre a porcentagem de células CD14 ${ }^{+}$ que produziram espécies reativas de oxigênio e intensidade de fluorescência (IMF) em valores arbitrários basal e estimulados por Mannheimia haemolytica, Staphylococcus aureus e Escherichia coli no sangue de bezerros sadios - São Paulo - 2014

Tabela 40 - Efeito in vitro da norfloxacina sobre a porcentagem de células CD14 ${ }^{+}$ que fagocitaram Mannheimia haemolytica, Staphylococcus aureus e Escherichia coli no sangue de bezerros sadios - São Paulo - 2014

Tabela 41 - Efeito in vitro da norfloxacina sobre a porcentagem de células $\mathrm{CH} 138^{+}$ que produziram espécies reativas de oxigênio e intensidade de fluorescência (IMF) em valores arbitrários basal e estimulados por Mannheimia haemolytica, Staphylococcus aureus e Escherichia coli no sangue de bezerros sadios - São Paulo - 2014

Tabela 42 - Efeito in vitro da norfloxacina sobre a porcentagem de células $\mathrm{CH} 138^{+}$ que fagocitaram Mannheimia haemolytica, Staphylococcus aureus e Escherichia coli no sangue de bezerros sadios - São Paulo - 2014 


\section{LISTA DE GRÁFICOS}

Gráfico 1 - Box Plot da porcentagem de células $\mathrm{CD}_{14}{ }^{+}$que produziram espécies reativas de oxigênio intracelular dos animais do Grupo 1 entre células do lavado broncoalveolar não estimuladas e estimuladas por bactérias - São Paulo - 2014

Gráfico 2 - Box Plot da porcentagem de células $\mathrm{CD}_{14}^{+}$que produziram espécies reativas de oxigênio intracelular dos animais do Grupo 2 entre células do lavado broncoalveolar não estimuladas e estimuladas por bactérias - São Paulo - 2014

Gráfico 3 - Box Plot das médias e dos erros padrão da porcentagem de granulócitos do sangue que produziram espécies reativas de oxigênio nos animais do Grupo 1 não estimulados e estimulados por bactérias - São Paulo - 2014

Gráfico 4 - Box Plot das médias e dos erros padrão da porcentagem de granulócitos do sangue que produziram espécies reativas de oxigênio nos animais do Grupo 2 não estimulados e estimulados por bactérias - São Paulo - 2014

Gráfico 5 - Box Plot das médias e dos erros padrão da porcentagem de granulócitos do sangue que fagocitaram as distintas bactérias dos animais do Grupo 1 - São Paulo - 2014

Gráfico 6 - Box Plot das médias e dos erros padrão da porcentagem de granulócitos do sangue que fagocitaram as distintas bactérias dos animais do Grupo 2 - São Paulo - 2014 


\section{LISTA DE QUADROS}

Quadro 1 - Momentos das coletas, exames realizados e material coletado dos 12 bovinos durante o período da pesquisa.

Quadro 2 - Anticorpos monoclonais primários e secundários (por tubo) para quantificação da produção intracelular de espécies reativas de oxigênio, fagocitose e imunofenotipagem das amostras de LBA no Citômetro de fluxo (FACSCalibur ${ }^{\mathrm{TM}}$ ) - São Paulo - 2014

Quadro 3 - Anticorpos monoclonais primários e secundários (por tubo) para realização do ensaio de viabilidade celular das amostras de lavado broncoalveolar no Citômetro de fluxo (FACSCalibur ${ }^{\mathrm{TM}}$ ) - São Paulo 2014

Quadro 4 - Anticorpos monoclonais primários e secundários (por tubo) para realização da quantificação da produção intracelular de espécies reativas de oxigênio, fagocitose e imunofenotipagem das amostras de sangue no citômetro de fluxo (FACSCalibur ${ }^{\mathrm{TM}}$ ) - São Paulo - 2014

Quadro 5 - Anticorpos monoclonais primários e secundários (por tubo) para realização do ensaio de viabilidade celular das amostras de sangue no citômetro de fluxo (FACSCalibur ${ }^{\mathrm{TM}}$ ) - São Paulo - 2014

Quadro 6 - Manifestações clínicas observadas durante o estabelecimento do quadro clínico de mannheimiose após indução experimental de pneumonia por Mannheimia haemolytica - São Paulo - 2014 


\section{LISTA DE FIGURAS}

Figura 1 - Colônias de Mannheimia haemolytica em placa de ágar cérebro-coração com $5 \%$ de sangue de carneiro para a realização de contagem de unidades formadoras de colônia - São Paulo - 2013.

Figura 2 - Colônias de Mannheimia haemolytica em ágar cérebro-coração com 5 \% de sangue desfibrinado de carneiro, crescimento do material recuperado dos animais inoculados como $M$. haemolytica, após surgimento do conjunto de manifestações clínicas - São Paulo - 2014

Figura 3 - Provas de catalase (+) e Gram (cocobacilo Gram -) para identificação da bactéria recuperada dos animais inoculados como Mannheimia haemolytica, após surgimento do conjunto de manifestações clínicas São Paulo - 2014

Figura 4 - Teste API identificando a bactéria recuperada dos animais inoculados como Mannheimia haemolytica, após surgimento do conjunto de manifestações clínicas. (Foto superior pré incubação, foto inferior após 24 h à $37{ }^{\circ} \mathrm{C}$ de incubação com a bactéria recuperada de bezerro) - São Paulo - 2014

Figura 5 - Demonstração da intensidade de fluorescência da bactéria Mannheimia haemolytica não conjugada à R-Phycoeritrin (à esquerda em preto) e conjugada à $R$-Phycoeritrin (à direita em laranja) verificada pela citometria de fluxo - São Paulo - 2014 58

Figura 6 - Identificação das populações de leucócitos alveolares - São Paulo - 2014

Figura 7 - Identificação das populações de macrófagos alveolares expressando CD14 - São Paulo - 2014

Figura 8 - Macrófagos alveolares expressando CD14 que produziram espécies reativas de oxigênio intracelular - São Paulo - 2014

Figura 9 - Macrófagos alveolares expressando CD14 que produziram espécies reativas de oxigênio intracelular (FL1) e fagocitaram bactérias (AMannheimia haemolytica (FL2); B- Staphylococcus aureus; CEscherichia coli (FL4)) - São Paulo - 2014.

Figura 10 - Identificação das populações de granulócitos e mononucleares do sangue de bezerros - São Paulo - 2014 .

Figura 11 - Identificação das populações de granulócitos sanguíneos expressando CH138 - São Paulo - 2014

Figura 12 - Granulócitos sanguíneos expressando CH138 que produziram espécies reativas de oxigênio intracelular. São Paulo - 2014

Figura 13 - Granulócitos sanguíneos expressando $\mathrm{CH} 138$ que produziram espécies reativas de oxigênio intracelular (FL1) e fagocitaram bactérias (A- 
Mannheimia haemolytica (FL2); B- Staphylococcus aureus; CEscherichia coli (FL4)) - São Paulo - 2014.

Figura 14 - Identificação das populações de monócitos sanguíneos expressando CD14 - São Paulo - 2014

Figura 15 - Monócitos sanguíneos expressando CD14 que produziram espécies reativas de oxigênio intracelular - São Paulo - 2014

Figura 16-Monócitos sanguíneos expressando CD14 que produziram espécies reativas de oxigênio intracelular (FL1) e fagocitaram bactérias (AMannheimia haemolytica (FL2); B- Staphylococcus aureus; CEscherichia coli (FL4)) - São Paulo - 2014

Figura 17 - Presença de secreção seromucosa durante o quadro broncopneumônico São Paulo - 2014

Figura 18 - $Q R$ code representativo do vídeo da evolução do quadro durante os quatro momentos da infecção experimental por Mannheimia haemolytica (https://youtu.be/xqsy2bTIjs8).....

Figura 19 - Imagens videobroncoscópicas do mesmo animal sadio (M1) (esquerda) e com pneumonia (M2) (direita) induzida pela inoculação de Mannheimia haemolytica, na figura da direita a presença de secreção mucopurulenta amarelo-esverdeada na região da carina - São Paulo, 2014

Figura 20 - Imagens videobroncoscópicas obtidas durante o quadro pneumônico por Mannheimia haemolytica: à esquerda presença de secreção mucopurulenta antes da entrada do lobo cranial direito e à direita presença de coloração avermelhada e edema em região de brônquios São Paulo, 2014

Figura 21 - Representação gráfica da evolução da fagocitose de Mannheimia haemolytica do mesmo animal durante os quatro momentos da infecção experimental por Mannheimia haemolytica - São Paulo - 2014. 


\section{SUMÁRIO}

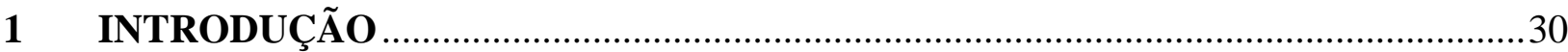

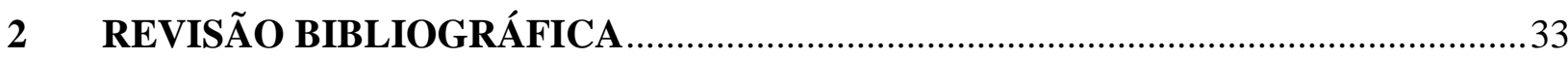

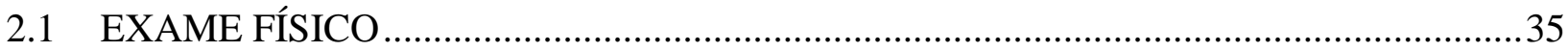

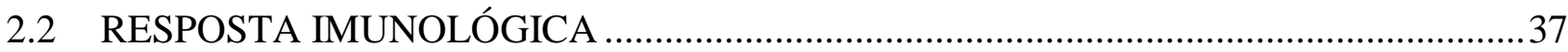

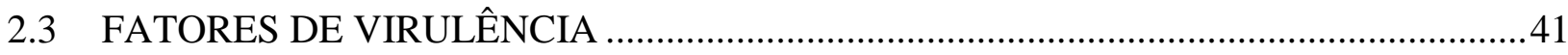

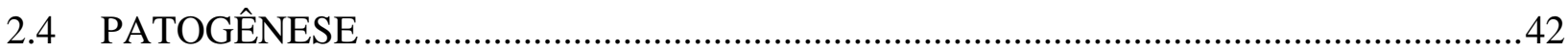

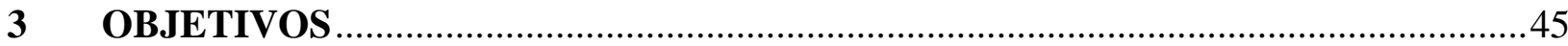

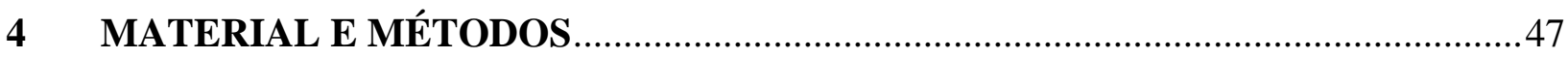

4.1 PREPARO DO INÓCULO PARA A INDUÇÃO DA DOENÇA.......................................47

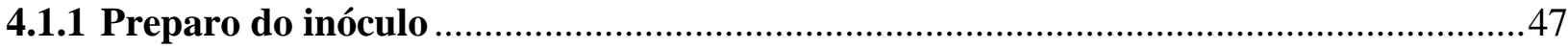

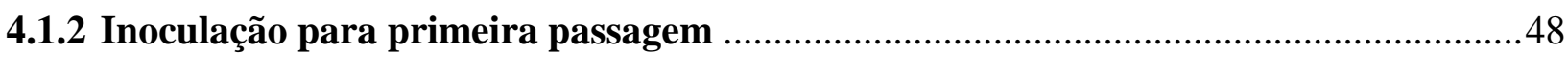

4.2 ANIMAIS UTILIZADOS E DELINEAMENTO EXPERIMENTAL ..............................51

4.2.1 Exames físico e específico do sistema respiratório ....................................................52

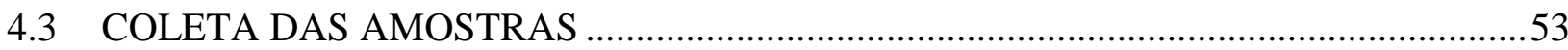

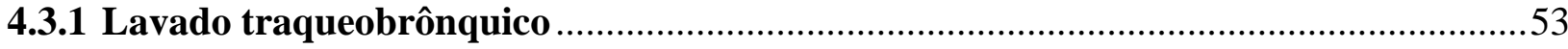

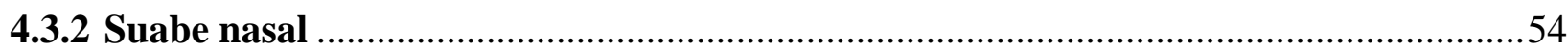

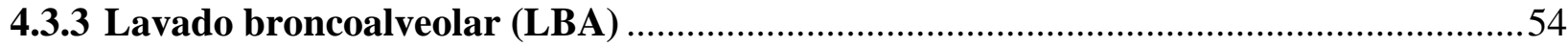

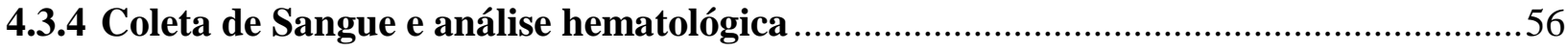

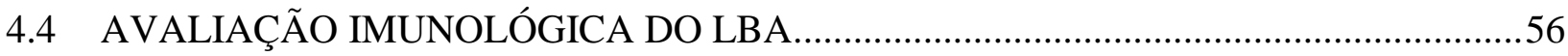

4.4.1 Conjugação da Mannheimia haemolytica à $R$-Phycoerythrin (R-PE) .........................56

4.4.2 Avaliação funcional dos fagócitos do LBA ….......................................................58

4.4.3 Quantificação e identificação de células mononucleares do LBA ...............................59

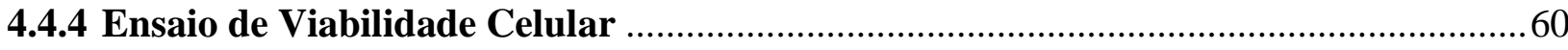

4.5 AVALIAÇÃO IMUNOLÓGICA DAS AMOSTRAS DE SANGUE ...............................61

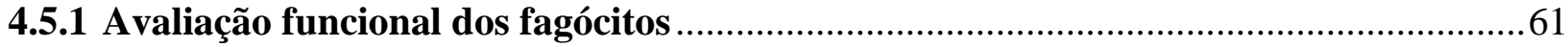

4.5.2 Quantificação e identificação dos leucócitos sanguíneos ..........................................62

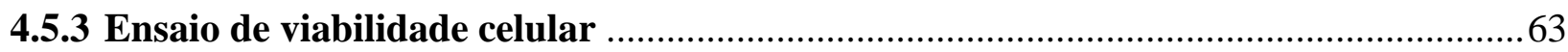

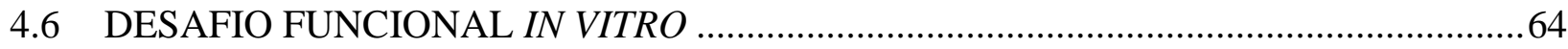


4.7 ANÁLISE DA CITOMETRIA DE FLUXO.

4.8 EXPRESSÃO DE CITOCINAS EM CÉLULAS SANGUÍNEAS E

BRONCOALVEOLARES VERIFICADAS POR PCR EM TEMPO REAL ............................70

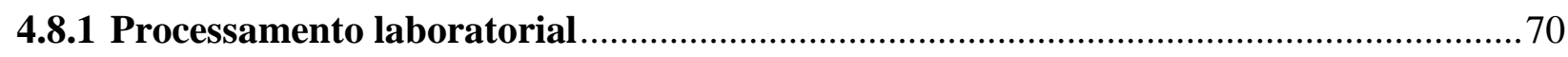

4.8.2 Extração de RNA e síntese de DNA complementar .................................................. 71

4.8.3 PCR quantitativo em tempo real por transcriptase reversa (RT- qPCR) ................. 71

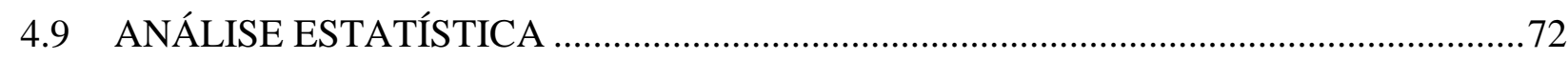

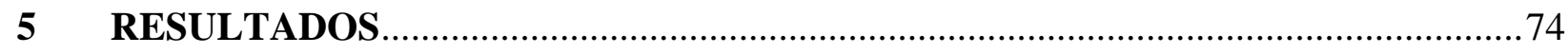

5.1 EXAMES FÍSICO GERAL E ESPECÍFICO DO SISTEMA RESPIRATÓRIO ................74

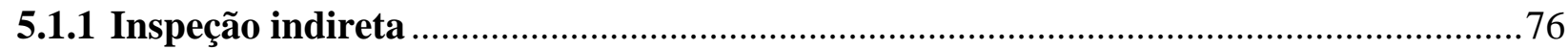

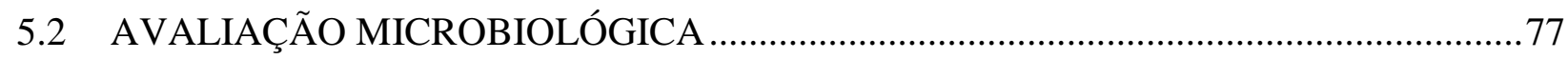

5.3 AVALIAÇÃO DO LAVADO BRONCOALVEOLAR ................................................ 78

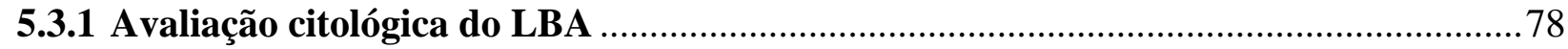

5.3.2 Fenotipagem das células mononucleares do LBA ….............................................. 79

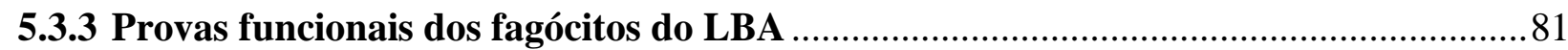

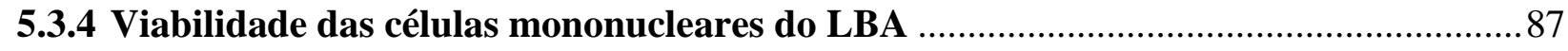

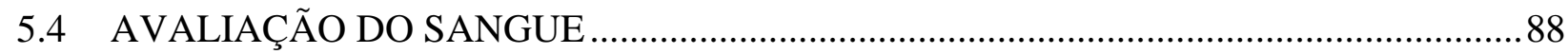

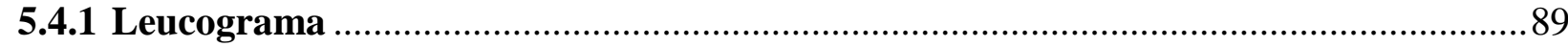

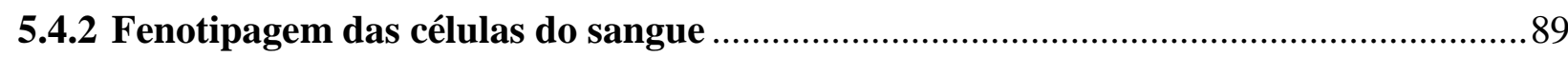

5.4.3 Provas funcionais dos fagócitos do sangue ............................................................. 92

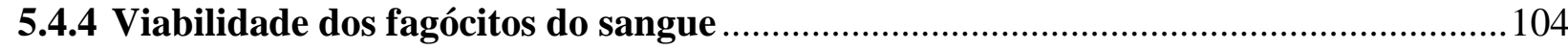

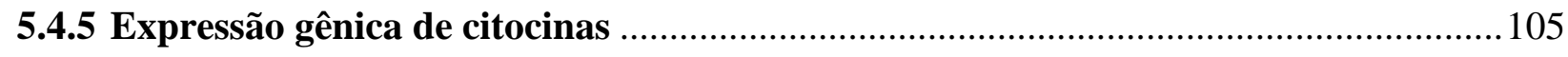

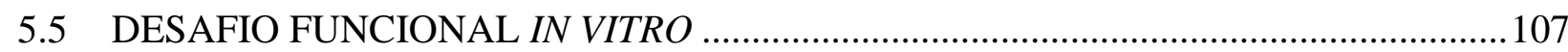

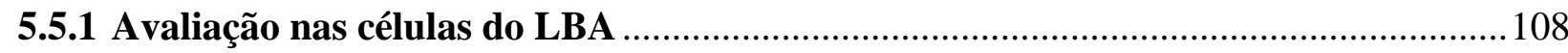

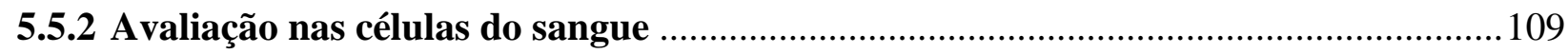

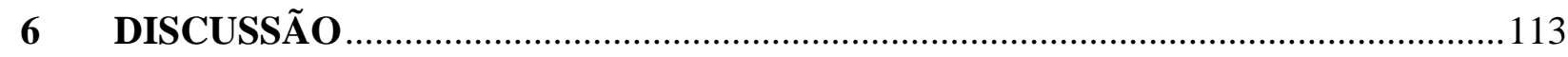

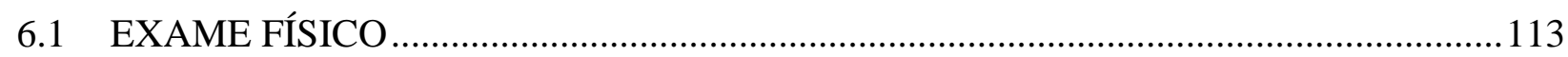

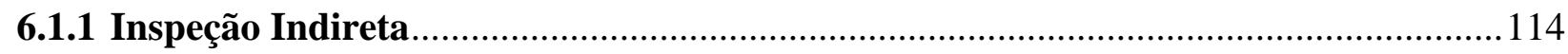

6.2 CULTURA BACTERIOLÓGICA ........................................................................... 115

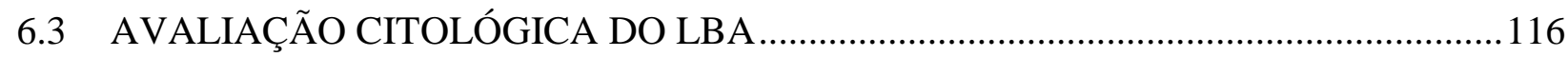


6.4.1 Fenotipagem das células mononucleares do LBA ….............................................. 117

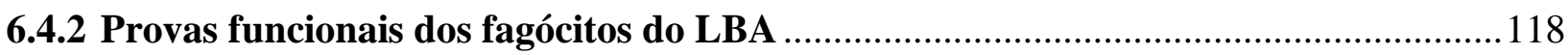

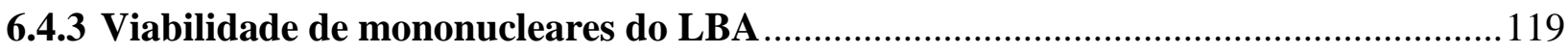

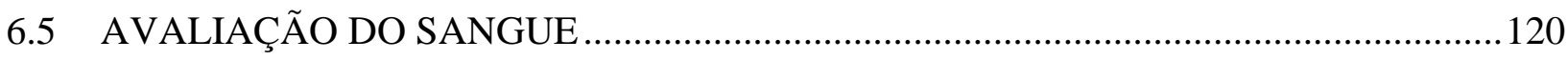

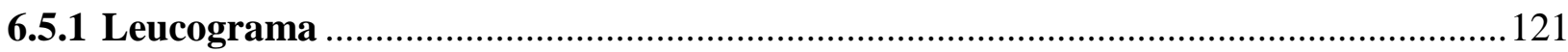

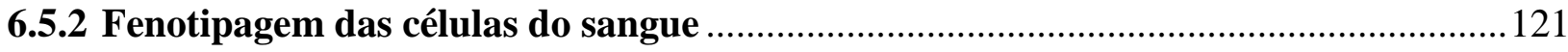

6.5.3 Provas funcionais dos fagócitos do sangue .......................................................... 122

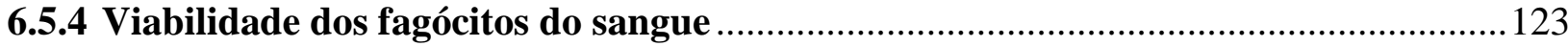

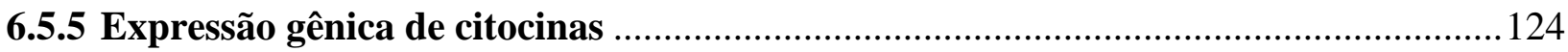

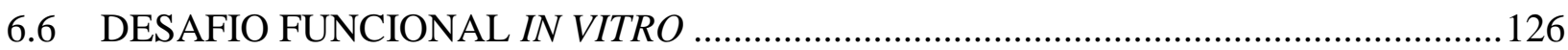

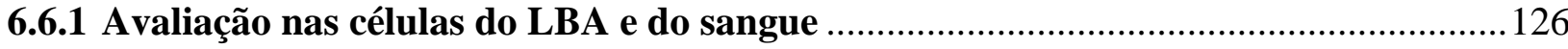

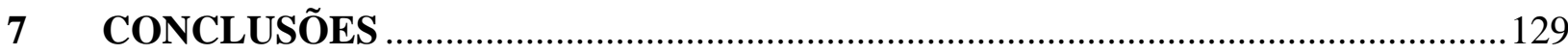

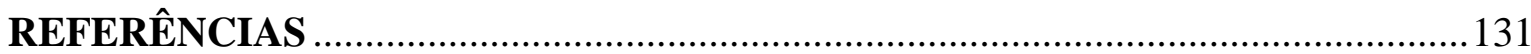


Intradusãa 


\section{INTRODUÇÃO}

O impacto econômico da bovinocultura à produção nacional é indiscutível e gerou lucro bruto de aproximadamente $\mathrm{R} \$ 67$ bilhões em 2014. Neste mesmo ano o rebanho composto por mais de 211 milhões de bovinos, permitiu o abate de 33907 milhões de cabeças e a produção de 24741 bilhões de litros de leite (IBGE. INSTITUTO BRASILEIRO DE GEOGRAFIA E ESTATÍSTICA, 2015). Neste contexto, a perda de bezerros representa prejuízo considerável, pois além da sua morte comprometer as taxas de reposição, impede o retorno do investimento na concepção e nascimento, muitas vezes expressivo. De acordo com as observações de Gonçalves et al. (1993) e Benesi (1996), as taxas de mortalidade de bezerros no Brasil podem chegar a $25 \%$, sendo causadas especialmente por diarreias e enfermidades respiratórias.

Dentre as afecções do sistema respiratório, a mais comum é o Complexo Doença Respiratória dos Bovinos (CDRB) (AMES; BAKER; WIKSE, 2006). Possui etiologia multifatorial e qualquer estímulo estressante pode afetar adversamente o sistema imune do hospedeiro, e o aumento dessa susceptibilidade pode favorecer infecções, até mesmo por microrganismos oportunistas (LEKEUX, 1994; GONÇALVES et al., 2000; ACKERMANN; DERSCHEID; ROTH, 2010; CASWELL, 2013).

Apesar da diversidade etiológica do CDRB, existem peculiaridades atribuidas a Mannheimia haemolytica (anteriormente denominada Pasteurella haemolytica) (GRIFFIN, 2010), habitante normal da nasofaringe de bovinos, que nas situações de menor efetividade dos mecanismos de defesa do trato respiratório, atinge regiões mais profundas, causando a Mannheimiose Pneumônica Bovina (MPB) (MALAZDREWICH et al., 2001; KATSUDA et al., 2008; SINGH; RITCHEY; CONFER, 2011; SATHIAMOORTHY et al., 2012). E mesmo sendo oportunista, $M$. haemolytica causa pneumonias graves, normalmente acompanhadas de exsudato fibrinonecrótico e hemorragia alveolar (AULIK; HELLENBRAND; CZUPRYNSKI, 2012; CRADDICK et al., 2012; SINGH et al., 2012).

Exemplos de mecanismos de defesa comprometidos incluem, danos às células que revestem o trato respiratório superior por vírus, tais como Vírus da Rinotraqueíte Infecciosa Bovina (IBR), Vírus da Parainfluenza (PI-3), ou Vírus Sincicial Respiratório Bovino (BRSV). Danos ao revestimento traqueal também podem ocorrer, devido às substâncias irritantes 
inaladas como amônia ou poeira. O mecanismo de defesa respiratória também pode ser deprimido devido à imunossupressão associada com Diarreia Viral Bovina (BVD) (IRSIK, 2010).

Outro importante aspecto a ser considerado é a mudança da efetividade das células imunes relacionadas à idade (YOUSSEF; CLARK; CASWELL, 2004; BATISTA, 2011; BATISTA et al., 2012). Assim, os estudos tornam-se mais relevantes quando envolvem animais acima de seis meses de idade, pois se observa o efeito do patógeno nas células imunes maduras, além de ser representativa a susceptibilidade dos animais dessa idade à doença, ou seja, bovinos em sistemas de alta tecnificação, como grandes confinamentos e lotes de animais desmamados sobre alta pressão social (REZENDE, 2010).

Os estudos clínicos com infecção experimental por Mannheimia sp. normalmente focaram na investigação das lesões macro e microscópicas (FAGLIARI, 2003; YOUSSEF; CLARK; CASWELL, 2004; HANZLICEK et al., 2010; SATHIAMOORTHY et al., 2012), e portanto a literatura carece de pesquisas que avaliem os mecanismos que levam ao desenvolvimento do quadro clínico, ou seja, a resposta do hospedeiro à infecção.

Considerando o perfil oportunista da M. haemolytica, o maior obstáculo para a minimização da ocorrência da infecção por este patógeno recai na carência de estudos sobre os principais aspectos relacionados às alterações imunológicas locais e sistêmicas decorrentes da infecção. Portanto, a melhor compreensão das alterações imunes decorrentes da pneumonia induzida experimentalmente por $M$. haemolytica, é fundamental para o entendimento da doença, e para se estabelecer uma conduta mais racional e eficaz em animais acometidos, pois quanto mais especializada a pecuária, maior será a demanda por estratégias que minimizem os efeitos adversos de fatores genéticos, fisiológicos e ambientais relacionados ao sistema de produção. Diante do supracitado, fica claro a importância da melhor compreensão da evolução da infecção e do tratamento, por meio de exame físico, inspeção indireta das vias respiratórias por endoscopia respiratória e avaliação da resposta imune de bezerros para a intervenção mais racional nesta enfermidade. 
ORevisãa OBbliagráfica 


\section{REVISÃO BIBLIOGRÁFICA}

Entre as enfermidades infecciosas que acomentem bovinos jovens, as do sistema respiratório estão entre as maiores causas de perdas econômicas em âmbito mundial (JARAMILLO-ARANGO; TAVERA; SUÁREZ-GÜEMES， 2009). Calcula-se que aproximadamente $25 \%$ dos bezerros apresentam pelo menos uma vez um episódio de doença respiratória durante o primeiro ano de vida (ZECCHINON; FETT; DESMECHT, 2005). As maiores taxas de mortalidade de bezerros são registradas ao longo do primeiro mês de vida (BENESI, 1993), sendo a broncopneumonia considerada como um grande desafio, atingindo $12,7 \%$ de bezerros criados em sistema extensivo, e constituindo 23,9 \% das afecções que acometem bezerros com até um ano de idade (RABELO et al., 1996).

As características específicas do pulmão dos bovinos, estão resumidos como se segue: o pulmão esquerdo consiste em dois lóbulos (lobo cranial, que é dividido em dois segmentos, e lobo caudal), enquanto o pulmão direito consiste de quatro lóbulos (lobo cranial, lobo médio, lobo caudal e lobo acessório). Ao contrário da anatomia do pulmão da maioria dos outros mamíferos, o ramo do brônquio do lobo cranial direito sai diretamente da lateral direita da traqueia (PROHL et al., 2014).

A anatomia do pulmão bovino contribui para a instalação de doenças infecciosas, pois apresenta elevado grau de lobulação e percentagem de tecido intersticial que conduz uma relativa baixa complacência pulmonar específica e maior resistência do tecido pulmonar. Esse elevado grau de lobulação leva à forte independência dos segmentos. Assim, os processos inflamatórios são limitados por septos de tecido conjuntivo, entre segmentos doentes e saudáveis, e muitas vezes encontram-se dentro do mesmo lobo (PROHL et al., 2014). Resumindo, as caracteristicas do sistema respiratório dos bovinos que compreendem as vias aéreas estreitas, caixa torácica muito rígida, volume pulmonar pequeno e a compartimentalização pulmonar, são responsáveis por trocas gasosas menos efetivas, atividade macrofágica alveolar mais lenta e menor velocidade de limpeza pulmonar em comparação à outros mamíferos facilitando a entrada do patógeno, e dificultando a sua saída, aumentando a possibilidade de causar uma doença (GONÇALVES et al., 2000; ACKERMANN; DERSCHEID; ROTH, 2010; GRIFFIN et al., 2010).

Apesar dessa susceptibilidade anatômica, o trato respiratório de um bovino saudável tem vários mecanismos que impedem os microrganismos patogênicos de colonizar os tecidos 
expostos, incluindo produção de muco e os cílios, para interceptar e remover fisicamente microrganismos e partículas estranhas, a resposta imune de mucosa, e a manutenção de uma população simbiótica de bactérias comensais em região anterior do sistema respiratório (ACKERMANN; DERSCHEID; ROTH, 2010).

Porém, quando infectados por patógenos respiratórios primários, como os vírus (BRODERSEN, 2010; JONES; CHOWDHURY, 2010; RIDPATH, 2010), as defesas respiratórias do hospedeiro ficam prejudicadas, e microrganismos comensais do trato respiratório anterior e nasofaringe de ruminantes saudáveis podem se tornar patogênicos oportunistas, sendo os mais comuns Pasteurella multocida, Histophilus somni, M. haemolytica e Mycoplasma bovis (WIKSE, 1985; CASWELL et al., 2010; GRIFFIN et al., 2010). Outros fatores, incluindo o estado nutricional, estresse e qualidade do ar também podem desempenhar papéis que prejudicam os mecanismos de defesa do hospedeiro (ACKERMANN; DERSCHEID; ROTH, 2010; GORDEN; PLUMMER, 2010).

Dentre estes agentes etiológicos destaca-se a $M$. haemolytica, por ser a principal bactéria isolada de bovinos com doença respiratória (RICE et al., 2007; JARAMILLOARANGO; TAVERA; SUÁREZ-GÜEMES, 2009; SINGH; RITCHEY; CONFER, 2011; TESFAYE; SISAY TESSEMA; TEFERA, 2013; TAYLOR et al., 2015) que causa pneumonia lobar fibrinonecrótica e pleuropneumonias em bovinos (RICE et al., 2007), considerada a mais patogênica associada ao CDRB (JARAMILLO-ARANGO; TAVERA; SUÁREZ-GÜEMES, 2009; GRIFFIN, 2010; SINGH; RITCHEY; CONFER, 2011) e por causar grandes danos à pecuária mundial (RICE et al., 2007).

Nesses casos de infecção bacteriana deve-se instaurar a terapia antimicrobiana para controlar ou interromper a replicação do patógeno (AMES; BAKER; WIKSE, 2006; OZKANLAR et al., 2012, ILLAMBAS et al., 2013). A utilização de anti-inflamatórios também pode ser indicada em alguns casos, pois resulta na melhora das manifestações clínicas e na redução da consolidação pulmonar (AMES; BAKER; WIKSE, 2006; OZKANLAR et al., 2012). O uso de anti-inflamatórios não esteroidais por via intravenosa, logo após o aparecimento das manifestações clínicas, tornam as lesões pulmonares consistentemente menos severas do que em animais não tratados, além de estabilizar as manifestações clínicas (WALLEMACQ et al., 2008). 


\subsection{EXAME FÍSICO}

Observar o comportamento dos animais ainda é considerada a principal forma de rastrear em um rebanho quais animais estão apresentando algum tipo de alteração, sendo que a observação de tosse, respiração abdominal anormal e secreção nasal auxilia no diagnóstico da doença respiratória (GODINHO et al., 2007; MCGUIRK, 2008; ANGEN et al., 2009; BRSCIC et al., 2012; LERUSTE et al., 2012; LOVE et al., 2014; OLLIVETT, 2014). Essas alterações acompanhadas do aumento das frequências cardíaca e respiratória e da temperatura retal podem confirmar o diagnóstico (GONÇALVES et al., 2000; FAGLIARI, 2003; HANZLICEK et al., 2010).

Porém, algumas vezes animais aparentemente sadios podem estar acometidos por alguma doença respiratória, não sendo possível estabelecer o diagnóstico correto e precoce, sendo necessário o emprego de métodos semiológicos tradicionais (KOTERBA, 1993). O exame físico, em particular a auscultação pulmonar, nem sempre é elucidativa para a doença respiratória, e o diagnóstico definitivo requer exames complementares mais específicos como radiografia, broncoscopia ou análises citológicas e microbiológicas do trato respiratório (GONÇALVES et al., 2004; BATISTA et al., 2010; BENESI et al., 2012, 2013).

Tais exames podem auxiliar na detecção dos agentes infecciosos, no delineamento do perfil de resposta do sistema respiratório, no grau da lesão, no local acometido, favorecendo a melhor escolha da terapia a ser utilizada e a obtenção de um prognóstico mais preciso (GONÇALVES, 1997; GONÇALVES; FEITOSA, 2008; COOPER; BRODERSEN, 2010; BATISTA, 2011).

Análises microbiológicas, citológicas e imunológicas das secreções do trato respiratório são importantes no auxílio ao diagnóstico e na determinação do estadiamento da doença (GONÇALVES et al., 2004), uma vez que o sucesso do tratamento da doença está intimamente relacionado ao seu diagnóstico precoce e o reconhecimento do agente etiológico (GONÇALVES, 1997; BENESI et al., 2012).

Além das técnicas de coleta do lavado para citologia e exame microbiológico podemos realizar ainda a inspeção indireta das vias aéreas por broncoscopia. Esta técnica é excelente por permitir direcionar e selecionar os locais de lavagem, além de proporcionar a visibilização direta das vias aéreas (THRUNAVUKKARASU et al., 2005). 
Para realizar a inspeção das vias aéreas pulmonares pode-se utilizar a broncoscopia por fibra óptica, a qual é um procedimento extremamente seguro e vem sendo utilizado em humanos desde a década de 1960 (DOOMS et al., 2010; DIONÍSIO, 2012). O broncoscópio flexível é o mais amplamente usado instrumento minimamente invasivo para o diagnóstico e tratamento de doenças broncopulmonares em humanos, sua capacidade de atingir vias aéreas mais distais e parênquima pulmonar, com sedação leve a moderada, principalmente é responsável por sua popularidade (CASAL; OST; EAPEN, 2013). Em humanos, o European Respiratory Society e a American Thoracic Society publicaram guias e recomendações para realização do lavado broncoalveolar (LBA) por broncoscopia (European Society of Pneumology Task Group on BAL e American Thoracic Society), que permite também a inspeção do trato respiratório, sendo uma ferramenta importante no procedimento.

Em bezerros a broncoscopia experimental foi descrita pela primeira vez em 1968 (HILDING, 1968), porém não foi amplamente difundida em ruminantes, ao contrário do que ocorreu com equinos e animais de pequeno porte, principalmente em cães (THRUNAVUKKARASU et al., 2005).

Como técnica auxiliar ao diagnóstico das doenças respiratórias os veterinários podem empregar a análise das secreções respiratórias. O uso de exames complementares como a citologia do trato respiratório é uma importante técnica diagnóstica nestes casos (BENESI et al., 2012).

A recuperação de células do trato respiratório pode ser feita por meio da lavagem traqueobrônquica (LTB) como a traqueocentese, que recupera células de vias anteriores ou através do LBA que pode ser realizado por sondagem nasotraqueal (GONÇALVES et al., 2004) que é realizada às cegas, ou por endoscopia broncoscópica ou broncoscopia, que recupera células mais representativas do espaço alveolar.

Durante o LBA, o broncoscópio é direcionado para vias aéreas posteriores (bronquíolos e alvéolos) para minimizar a contaminação pela amostragem de grandes vias respiratórias (seios paranasais e traqueia). Em estudos com ovinos (PETERSON et al., 1990) e bovinos (BATISTA, 2011; BATISTA et al., 2012; BELLINAZZI et al., 2013) esta técnica foi considerada como eficaz para a coleta do fluido broncoalveolar e tem sido demonstrado que repetidas lavagens broncoalveolares foram bem toleradas por esses animais. 


\subsection{RESPOSTA IMUNOLÓGICA}

O corpo é protegido de agentes infecciosos e dos danos que eles causam, e de outras substâncias nocivas, por uma variedade de células efetoras e moléculas, que juntas constituem o sistema imune. Para proteger o indivíduo de maneira eficaz contra uma doença, o sistema imune deve satisfazer quatro principais características: reconhecimento imunológico, funções imune efetoras, regulação imune e capacidade de produzir memória imunológica (MURPHY, 2014).

A defesa contra invasores é mediada pelas reações iniciais da imunidade inata e as respostas tardias da imunidade adquirida. A imunidade natural ou imunidade inata é a linha de defesa inicial contra os microrganismos por meio de mecanismos celulares e bioquímicos que já existiam antes do estabelecimento de uma infecção e que estão programados para responder rapidamente a infecções (ABBAS; LICHTMAN; PILLAI, 2012; TIZARD, 2014). O sistema imune inato não tem memória, portanto cada infecção é tratada da mesma maneira e intensidade, não importando a frequência com que se detecte o patógeno, porém está sempre pronto para atuar quando encontrar qualquer agente (TIZARD, 2014).

Ao mesmo tempo que ocorre a tentativa de eliminar o invasor, uma resposta adaptativa é estimulada, gerando células efetoras específicas e de memória, capazes de prevenir uma infecção pelo mesmo microrganismo (ABBAS; LICHTMAN; PILLAI, 2012). Nos bovinos a maior parte da maturidade do sistema imune é observada por volta de cinco a oito meses de idade (CORTESE, 2009).

Em relação ao sistema respiratório, as defesas começam primeiramente por barreiras físicas, partículas maiores são filtradas na cavidade nasal e as menores que conseguem atingir os pulmões são submetidas às barreiras da própria mucosa do trato respiratório e ainda à eliminação por reflexo da tosse e espirros. As partículas depositadas na zona coberta por cílios são removidas pelo mecanismo de limpeza mucociliar (GONÇALVES; FEITOSA, 2008); e as partículas menores que conseguem ultrapassar essa barreira são fagocitadas pelos macrófagos alveolares (TIZARD, 2014).

A principal célula residente do trato respiratório posterior é o macrófago alveolar que representa a principal defesa celular do pulmão sendo responsável pela fagocitose de partículas exógenas, apresentação de antígenos para outras células, entre outras mediações inflamatórias, mantendo a homeostase imunológica do pulmão (LOHMANN-MATTHES; 
STEINMÜLLER; FRANKE-ULLMANN，1994; ACKERMANN; DERSCHEID; ROTH, 2010). Outra população leucocitária compreende os neutrófilos que são mais eficientes na fagocitose e morte bacteriana que os macrófagos, porém liberam produtos reativos que podem também causar injúrias teciduais (BURTON et al., 2005).

A fagocitose é uma defesa imunitária inata, que é definida pela ativação de redes de sinalização complexas que são estimuladas por contato com um microrganismo (PERTICARARI; PRESANI; BANFI, 1994; UNDERHILL; OZINSKY, 2002). As células fagocíticas desempenham papel fundamental na defesa contra infecções, particularmente as bacterianas. A fagocitose e a atividade de explosão respiratória são duas das suas funções mais importantes e essenciais para a eliminação de bactérias invasoras (PAAPE et al., 2003; NAUSEEF; CLARK, 2010).

Após fagocitarem, as células liberam grânulos com substâncias microbicidas em um processo complexo e altamente eficiente. Dentre estas substâncias, as espécies reativas de oxigênio (ERO), incluindo superóxidos, peróxido de hidrogênio e ácido hipocloroso, assumem grande importância, sendo o principal e mais estudado mecanismo de defesa destas células (SEGAL, 2005); este processo é benéfico quando direcionado para a eliminação de bactérias internalizadas, mas pode ser prejudicial quando células e tecidos adjacentes são afetados (KLEBANOFF, 1980).

$\mathrm{Na}$ tentativa de controlar o processo infeccioso e os danos causados pelo patógeno e pelas substâncias liberadas durante a fagocitose, o influxo de neutrófilos para o tecido inflamado é crucial. Durante as infecções pulmonares, os neutrófilos saem da circulação por uma série de eventos que envolvem a adesão e transmigração através do endotélio vascular para o espaço intersticial (SOETHOUT; MÜLLER; RUTTEN, 2002). O passo inicial na adesão de leucócitos é mediado por interações entre L, E e P-selectinas. L-selectina é expressa por leucócitos, P-selectina é expressa pelo endotélio inflamado e plaquetas e, a E-selectina é expressa pelo endotélio inflamado. O passo subsequente, o rolamento, é mediado por interações entre as selectinas com ligantes glicosilados, seguido pela adesão endotelial envolvendo proteínas transmembrânicas, as $\beta 1$ e $\beta 2$ integrinas (ZECCHINON; FETT; DESMECHT, 2005). No caso das $\beta 2$ integrinas, existe uma cadeia $\beta$ comum (CD18) e uma cadeia $\alpha$ variável (CD11a, b, c ou d). A fase de adesão de leucócitos é mediada por interações entre a $\beta 2$ integrina CD11a/CD18 (Mac-1) e, a molécula de adesão intercelular (ICAM) 1 e a molécula de adesão celular vascular (VCAM) 1 (ZEMANS; COLGAN; DOWNEY, 2009). 
Para controlar a homeostase local, esses neutrófilos entram em processo de morte celular, conhecido como apoptose. A apoptose é um mecanismo de morte muito bem orquestrado e altamente regulado (THORNBERRY, 1998; VERMES; HAANEN; REUTELINGSPERGER, 2000; SAVILL et al., 2002), que apresenta características morfológicas e que culmina com a fagocitose dos corpúsculos apoptóticos pelos macrófagos locais e sem liberação de fatores inflamatórios e danos ao tecido vizinho (KERR; WYLLIE; CURRIE, 1972). A apoptose, atualmente, não é sinônimo de morte celular programada, pois esta última pode assumir características morfológicas não apoptóticas (KROEMER et al., 2009). Entretanto, em algumas situações de desequilíbrio homeostático, essas células podem morrer por necrose.

A necrose foi inicialmente descrita como um processo aleatório e incontrolável em que o citoplasma das células é liberado estimulando a inflamação nos tecidos, porém atualmente, já se aceita a ideia de que a necrose também seja um processo que sofre uma sequência organizada e, em alguns casos, pode ser considerado programado (GOLSTEIN; KROEMER, 2007; KRYSKO et al., 2008; CHO et al., 2010).

Atualmente se conhece vários tipos de morte celular e para evitar confusões o "Nomenclature Committee on Cell Death" (Comitê de nomenclatura em morte celular) desenvolveu um guia para orientar autores quanto às denominações corretas. De acordo com o comitê, existem 12 modalidades de morte celular caracterizadas pela morfologia das células, onde quatro são reconhecidas como típicas e oito como atípicas. As quatro típicas têm seus mecanismos bem descritos, são representadas por apoptose, autofagia, necrose e cornificação (KROEMER et al., 2009).

As mais estudadas e utilizadas são apoptose e necrose. A apoptose é essencial na resolução de processos inflamatórios (THORNBERRY, 1998; VERMES; HAANEN; REUTELINGSPERGER, 2000; SAVILL et al., 2002). É caracterizada por apresentar fragmentação do DNA, condensação da cromatina, encolhimento da célula e formação de corpos apoptóticos (THORNBERRY, 1998), além da externalização da fosfatidilserina. Assim, desequilíbrios nas taxas de apoptose podem levar ao predomínio das forças de proliferação e migração celulares, podendo levar à instalação de um processo inflamatório crônico.

A necrose é um processo que pode ser causado por dano físico ou biológico, e foi primeiramente diferenciado da apoptose através da análise de ultraestrutura de células sofrendo cada um desses tipos de morte celular (KERR; WYLLIE; CURRIE, 1972). A 
necrose é caracterizada por inchaço mitocondrial e perda imediata da integridade da membrana (DARZYNKIEWICZ et al., 1992), envolvendo extravasamento citoplasmático de moléculas pró-inflamatórias intracelulares e consequentes danos teciduais, enquanto a apoptose mantém a homeostase do tecido de forma segura e não-imunogênica (CHO et al., 2010; TIZARD, 2014).

Além do extenso estudo dos processos de morte nas doenças oncológicas e infecciosas, sabe-se que a interferência destes processos pode levar a diminuição das funções celulares de fagócitos como a explosão respiratória, fagocitose e quimiotaxia, predispondo o indivíduo a outras infecções (VAN OOSTVELDT et al., 2002).

Existe ainda uma forma de morte celular não classificada como apoptose ou necrose. As células que estão nessa categoria apresentam dupla marcação por Anexina $\mathrm{V}$ e por iodeto de propídeo (BLAGITZ et al., 2011; PESSOA et al., 2012), mas não apresentam valor biológico propriamente dito. Alguns autores acreditam que essa dupla marcação possa ser uma apoptose tardia ou necrose secundária, pois afirmam que ao iniciar o processo de apoptose a célula expõe a fosfatidilserina por aproximadamente quatro a seis horas, sendo marcada pela anexina, mas com o tempo a membrana torna-se permeável ao iodeto de propídeo, o que resultaria na dupla marcação (DARZYNKIEWICZ et al., 1992).

Todos esses processos de resposta imune são mediados pelas citocinas. As citocinas inflamatórias contribuem para a patogênese da mannheimiose, por meio do recrutamento de neutrófilos, ativação dos leucócitos, e a indução de uma ampla gama de mediadores inflamatórios solúveis, que durante a doença aumentam a expressão pulmonar de factor de necrose tumoral alfa (TNF- $\alpha$ ), Interleucina-1 beta (IL-1 $\beta$ ) e Interleucina-8 (IL-8) (MORSEY et al., 1999; MALAZDREWICH et al., 2001).

$\mathrm{Na}$ maior parte dos modelos mamíferos, TNF- $\alpha$, IL-1 $\beta$, IL-8 são componentes centrais de uma rede complexa de citocinas, que inicia, amplifica, e sustenta a resposta inflamatória no tecido; isso vale também para respostas inflamatórias agudas dentro do pulmão. TNF- $\alpha$ e IL-1 $\beta$ são mediadores da resposta inicial que estabelecem cascatas de citocinas através da ativação autócrina e parácrina de uma ampla gama de células (MALAZDREWICH et al., 2001).

Eles iniciam a transmigração de neutrófilos e a ativação das moléculas de adesão nos neutrófilos e endotélio microvascular. Embora não diretamente quimiotático para neutrófilos, tanto TNF- $\alpha$ quanto IL-1 $\beta$ induzem a secreção de IL-8, o quimiotático de neutrófilos e mais potente fator de ativação. Dessa forma, os neutrófilos podem promover a lesão do tecido 
através do estímulo de degranulação e a libertação extracelular de metabolitos do ácido araquidônico, ERO e enzimas proteolíticas (MALAZDREWICH et al., 2001; MITCHELL; ALBRIGHT; CASWELL, 2003).

\subsection{FATORES DE VIRULÊNCIA}

Vários fatores de virulência da $M$. haemolytica foram descritos: eles incluem a cápsula, que desempenha um grande papel na adesão e invasão; as proteínas da membrana externa, que são importantes na indução da resposta imunitária protetora; adesinas, implicadas na colonização; a neuraminidase, que reduz a viscosidade de muco respiratório e permite a aposição bacteriana à superfície celular; o lipopolissacarídeo (LPS) e a leucotoxina (LKT) (ZECCHINON; FETT; DESMECHT, 2005). Esses fatores permitem que $M$. haemolytica drible as defesas do hospedeiro para proliferar no pulmão e ocasione a morte de macrófagos alveolares e neutrófilos, o que aumenta ainda mais as lesões pulmonares (IOVANE et al., 1998). O polissacarídeo capsular do organismo afeta negativamente a capacidade fagocítica dos neutrófilos e a sialoglicoprotease afeta a eficácia dos anticorpos opsonizantes. Proteínas de membrana externa, reguladoras de ferro, permitem que $M$. haemolytica se replique no hospedeiro com baixas concentrações de ferro. Lipídeo A do LPS componente da parede celular é um fator de virulência importante relacionado com a ativação de macrófagos; também está associado com a liberação de TNF- $\alpha$, lesão vascular, e sinais inflamatórios observados, como febres altas e choque (RICE et al., 2007; GRIFFIN, 2010; GRIFFIN et al., 2010; SINGH; RITCHEY; CONFER, 2011).

Leucotoxina (LKT) é o mais importante e estudado fator de virulência da $M$. haemolytica, associada a danos nos pulmões, permitindo que a bactéria se instale e destrua as células fagocíticas do hospedeiro pela ligação à molécula CD18 (THUMBIKAT et al., 2005; ZECCHINON; FETT; DESMECHT, 2005; AULIK; HELLENBRAND; CZUPRYNSKI, 2012). Como a quantidade de LKT aumenta durante o processo infeccioso, os efeitos celulares também aumentam, levando a morte celular por apoptose seja preterida pela necrose (RICE et al., 2007; GRIFFIN, 2010; GRIFFIN et al., 2010; SINGH; RITCHEY; CONFER, 2011). Essa interação celular da LKT com os leucócitos bovinos não se encontra presente em 
leucócitos de outras espécies de mamíferos (ZECCHINON; FETT; DESMECHT, 2005; AULIK; HELLENBRAND; CZUPRYNSKI, 2012).

Para demonstrar a importância da LKT no desenvolvimento das lesões pulmonares, Singh et al. (2012) inocularam bezerros com M. haemolytica portando um gene LKT $^{-}$e $M$. haemolytica com $\mathrm{LKT}^{+}$, observando que os animais inoculados com a bactéria com o gene LKT $^{-}$não causaram lesões fibrinonecróticas e severas como os animais inoculados com a bactéria $\mathrm{LKT}^{+}$.

\subsection{PATOGÊNESE}

A exposição do animal a $M$. haemolytica causa rápida infiltração de neutrófilos para o pulmão e aumento acentuado na proporção de neutrófilos/macrófagos no LBA. Essas mudanças se correlacionam com alterações histológicas como infiltrados inflamatórios no alvéolos e presença de exsudato fibrinonecrótico (ZECCHINON; FETT; DESMECHT, 2005). Essa migração de neutrófilos contribui para o desenvolvimento do dano tecidual. Assim, a interação patógeno-hospedeiro é entre LKT e leucócitos polimorfonucleares (PMN) e a resposta inflamatória mediada por neutrófilos em si, parece ser um determinante importante da patogênese da mannheimiose (ZECCHINON; FETT; DESMECHT, 2005).

Alguns trabalhos demostraram que complexos de LPS com uma proteína de fase aguda é rapidamente formado, permitindo uma resposta inflamatória. Esta proteína, denominada proteína de ligação ao lipopolissacarídeo (LBP), liga-se com elevada afinidade em todos os quimiotipos de LPS através do lipídeo A. Complexos de LPS e LBP interagem com monócitos através de ligação específica para a molécula de superfície CD14, ativando essas células (IOVANE et al., 1998; ZECCHINON; FETT; DESMECHT, 2005).

A maioria dos tipos de lipídeo A liga-se a um receptor transmembrana conhecido como receptor do tipo Toll 4 (TLR4), presente em macrófagos e células endoteliais dos animais, através de uma interação que envolve outras proteínas, incluindo LBP e CD14. Em macrófagos, o lipídeo A desencadeia a biossíntese de diversos mediadores da inflamação, tais como TNF- $\alpha$ e IL-1 $\beta$ e ativa a produção de moléculas co-estimuladoras necessárias para a resposta imune adaptativa, eventos que são desejáveis para combater as infecções locais (CHEN et al., 1992; ULEVITCH; TOBIAS, 1995). 
Concentrações baixas e altas de LKT induzem apoptose e necrose, respectivamente, em leucócitos bovinos. A capacidade de baixas concentrações de LKT induzir a apoptose em leucócitos permite que as bactérias escapem da vigilância do sistema imune do hospedeiro, destruindo os protagonistas da resposta inata (macrófagos e neutrófilos), melhorando o processo inflamatório. Em concentrações mais elevadas, os mecanismos apoptóticos são excedidos e ocorre a necrose, gerando lesões pulmonares mais severas (ZECCHINON; FETT; DESMECHT, 2005). 
Oygaturas 


\section{OBJETIVOS}

\section{Objetivo Geral}

Objetivou-se com o presente estudo observar longitudinalmente a dinâmica dos principais aspectos de defesa das vias aéreas posteriores de bezerros inoculados experimentalmente com $M$. haemolytica, durante a infecção e após o tratamento.

\section{Objetivos Específicos}

$>\quad$ Avaliar a evolução da infecção experimental por $M$. haemolytica e o efeito do tratamento com antimicrobiano norfloxacina, associado ou não à flunixina meglumina, por meio de exame físico, acrescido de broncoscopia;

$>\quad$ Investigar o efeito da infecção experimental por M. haemolytica e do tratamento com antimicrobiano norfloxacina, associado ou não à flunixina meglumina, sobre as populações leucocitárias sanguíneas e broncoalveolares, sua capacidade fagocítica, produção intracelular de ERO e viabilidade celular em células $\mathrm{CD}_{14}{ }^{+}$sanguíneas e broncoalveolares, e em leucócitos $\mathrm{CH} 138^{+}$sanguíneos, além da expressão de L-selectina em leucócitos $\mathrm{CH} 138^{+}$do sangue;

Avaliar o efeito da infecção experimental por M. haemolytica e do tratamento com antimicrobiano norfloxacina, associado ou não à flunixina meglumina, sobre a expressão de citocinas (IL-1 $\beta$, IL-8 e TNF- $\alpha$ ) nas células sanguíneas e do LBA;

Avaliar o efeito in vitro da norfloxacina sobre a capacidade fagocítica e produção intracelular de ERO em células $\mathrm{CD}^{+} 4^{+}$sanguíneas e no LBA, e em leucócitos polimorfonucleares sanguíneos. 
Material Se Setodos 


\section{MATERIAL E MÉTODOS}

O projeto desenvolvido foi aprovado pela Comissão de Ética no uso de Animais da Faculdade de Medicina Veterinária e Zootecnia da Universidade de São Paulo, em 26 de outubro de 2011, protocolado sob o n $2436 / 2011$.

\subsection{PREPARO DO INÓCULO PARA A INDUÇÃO DA DOENÇA}

Inicialmente, para o preparo do inóculo e posterior inoculação da $M$. haemolytica foi necessário realizar uma passagem das bactérias em bovinos para garantir a infectividade do inóculo.

\subsubsection{Preparo do inóculo}

Foi adquirida comercialmente a cepa ATCC 33396 de $M$. haemolytica, que foi semeada em ágar cérebro coração (ACC) com $5 \%$ de sangue de ovino e $6 \mu \mathrm{g}$ de vancomicina por $\mathrm{mL}$ de ágar e incubadas em estufa a $37{ }^{\circ} \mathrm{C}$, por 24 horas. As colônias recuperadas foram inoculadas em $3 \mathrm{~mL}$ de caldo de infusão cérebro-coração (ICC) estéril e incubado sob aerobiose, a $37^{\circ} \mathrm{C}$, por 24 horas. Essa suspensão bacteriana foi aliquotada em criotubos com glicerina, estéril na proporção de $20 \%$ do volume, e, posteriormente, congeladas a $-80{ }^{\circ} \mathrm{C}$. Este procedimento foi realizado no Laboratório de Bacteriologia Aplicada do Departamento de Medicina Veterinária Preventiva da Escola de Veterinária da UFMG.

Os criotubos foram transportados para o Laboratório de Imunodiagnóstico do Departamento de Clínica Médica da Faculdade de Medicina Veterinária e Zootecnia da USP, onde para o preparo do inóculo foi utilizado $100 \mu \mathrm{L}$ da bactéria $M$. haemolytica (ATCC 33396) descongelada, que foi cultivada a $37{ }^{\circ} \mathrm{C}$ por 24 horas, em $3 \mathrm{~mL}$ de caldo de ICC. Após este período, $100 \mu \mathrm{L}$ do caldo foi retirado e adicionado à $20 \mathrm{~mL}$ de meio de cultura RPMI $1640^{1}$ estéril por 12 horas a $37^{\circ} \mathrm{C}$.

\footnotetext{
${ }^{1}$ Roswell Park Memorial Institute - RPMI 1640 Sigma ${ }^{\circledR}$ R7638
} 
Ao término das 12 horas, os $20 \mathrm{~mL}$ de cultura bacteriana em meio RPMI 1640 foram transportados para o Laboratório de Produção de Imunobiológicos do Instituto Biológico de São Paulo, onde, aos $20 \mathrm{~mL}$ de cultura bacteriana foram adicionados $500 \mathrm{~mL}$ de meio RPMI 1640 com 2,5\% de soro fetal bovino (SFB), $\mathrm{FeSO}_{4} .7 \mathrm{H}_{2} \mathrm{O}$ e $\mathrm{MgSO}_{4} .7 \mathrm{H}_{2} \mathrm{O}(0,75 \mathrm{mg}$ de cada para $5 \mathrm{~mL}$ de água destilada) estéril (GATEWOOD; FENWICK; CHENGAPPA, 1994; DU PREEZ; VAN RENSBURG; KILIAN, 2008), e para cada litro de RPMI 1640 foi adicionado $4 \mathrm{~mL}$ da solução.

A suspensão bacteriana foi colocada em frascos de Erlemmeyer e em estufa à $37^{\circ} \mathrm{C}$ sob agitação constante de 150 ciclos/minuto e a partir das três horas de incubação mediu-se a absorbância $^{2}$ (comprimento de onda de $600 \mathrm{~nm}$ ) seguida do plaqueamento para a contagem de unidades formadoras de colônia (UFC) (Figura 1). O procedimento foi repetido às seis, oito, nove e dez horas após o início da incubação, para determinação da curva de crescimento.

Após as 10 horas, o cultivo foi retirado da incubação, o material foi dividido em tubos cônicos de $50 \mathrm{~mL}$ e centrifugado a $5900 \mathrm{x} g$ por cinco minutos a $4{ }^{\circ} \mathrm{C}$ (CAVERLY et al., 2001). Para o preparo do inóculo a quantificação bacteriana deu-se inicialmente com base nos valores da densidade óptica (D.O.) obtidos à $10^{\mathrm{a}}$ hora de incubação (fase estacionária), e confirmados por contagem padrão em placa, utilizando diluições seriadas de 1:10, de modo que a concentração total de organismos viáveis da cepa de $M$. haemolytica no inóculo fosse $1 \times 10^{9}$ UFC (CONFER et al., 2009; COUTINHO et al., 2009).

\subsubsection{Inoculação para primeira passagem}

Para a primeira passagem do inóculo em modelo bovino foram utilizados quatro bezerros machos sem raça definida, com seis meses de idade, que apresentavam boa condição de saúde ao exame físico, hematológico e parasitológico, provenientes de propriedades leiteiras localizadas no Estado de São Paulo.

Após tricotomia e antissepsia da pele da região cervical ventral anterior com álcool iodado $5 \%$, um cateter $14 \mathrm{G}$ foi introduzido no espaço entre dois anéis traqueais do terço médio da traqueia. Em seguida, a dose de $5 \mathrm{~mL}$ correspondente a $1 \times 10^{9}$ UFC do inóculo de M. haemolytica foi infundida na luz da traqueia dos bezerros.

${ }^{2}$ Ultrospec 1000 UV/Visible Spectophotometer - Pharmacia Biotec ${ }^{\circledR}$ 
Os bezerros foram examinados de hora em hora até apresentarem o conjunto de manifestações clínicas que caracterizou a pneumonia, como apatia, dispnéia, alteração nos ruídos respiratórios, hipertermia, elevação das frequências cardíaca e respiratória e arritmia cardíaca (FAGLIARI, 2003). Assim que foram evidenciadas, realizou-se o lavado traqueobrônquico injetando-se, através de um cateter ${ }^{3}$ de $20,3 \mathrm{~cm}$ de comprimento e $2,1 \mathrm{~mm}$ de diâmetro, introduzido no espaço entre dois anéis traqueais do terço médio da traqueia, 20 $\mathrm{mL}$ de solução fisiológica 0,9 \% estéril a temperatura ambiente, com aspiração imediata da solução. A partir desse material coletado foi realizada a cultura e o antibiograma.

As colônias que cresceram no ACC com 5 \% de sangue desfibrinado de carneiro (Figura 2) foram identificadas por provas bioquímicas e morfo-tintoriais (Figura 3) e por meio do kit comercial API (Figura 4).

Figura 1 - Colônias de Mannheimia haemolytica em placa de ágar cérebro-coração com $5 \%$ de sangue de carneiro para a realização de contagem de unidades formadoras de colônia - São Paulo - 2013.

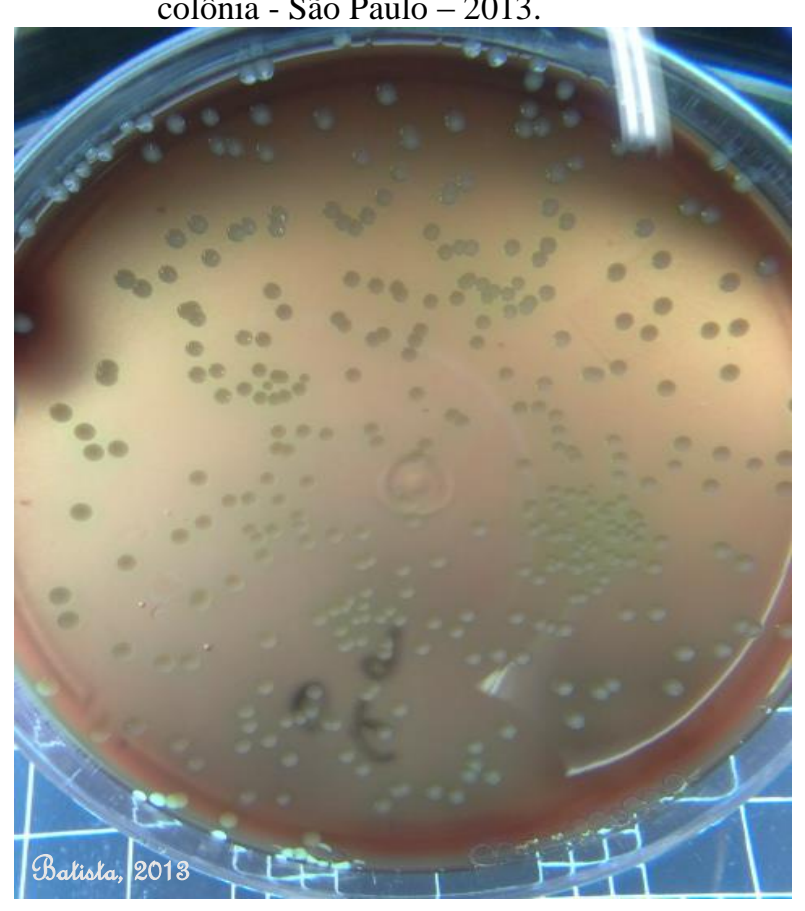

${ }^{3}$ BD Intracath Cateter Intravenoso Central ${ }^{\circledR}$ CAT: 785900 
Figura 2 - Colônias de Mannheimia haemolytica em ágar cérebrocoração com $5 \%$ de sangue desfibrinado de carneiro, crescimento do material recuperado dos animais inoculados como M. haemolytica, após surgimento do conjunto de manifestações clínicas - São Paulo - 2014

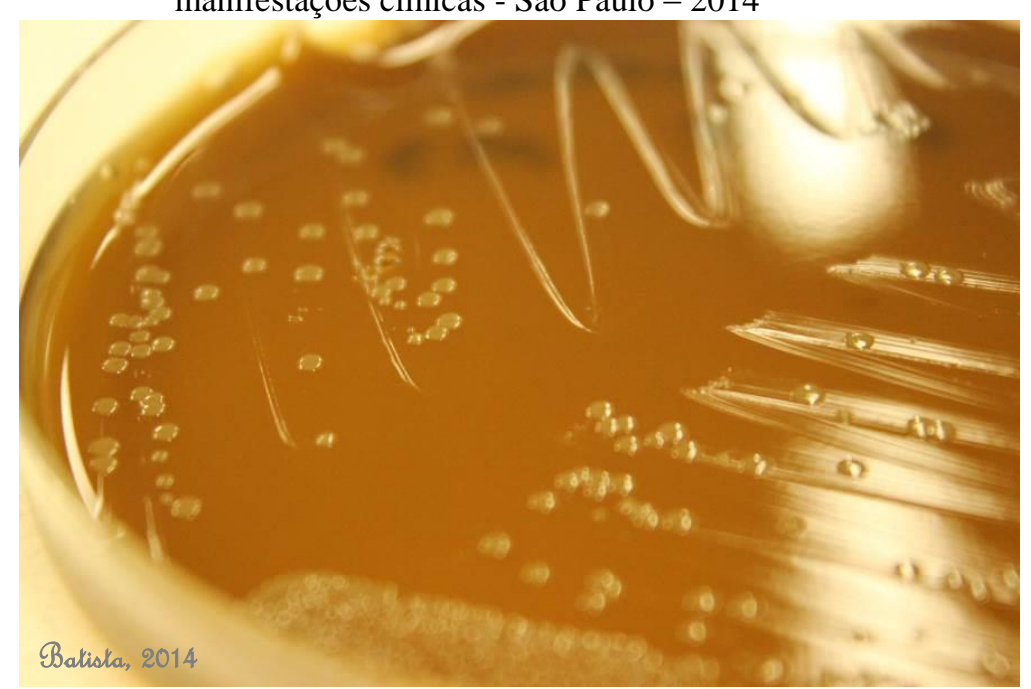

Figura 3 - Provas de catalase (+) e Gram (cocobacilo Gram -) para identificação da bactéria recuperada dos animais inoculados como Mannheimia haemolytica, após surgimento do conjunto de manifestações clínicas - São Paulo - 2014

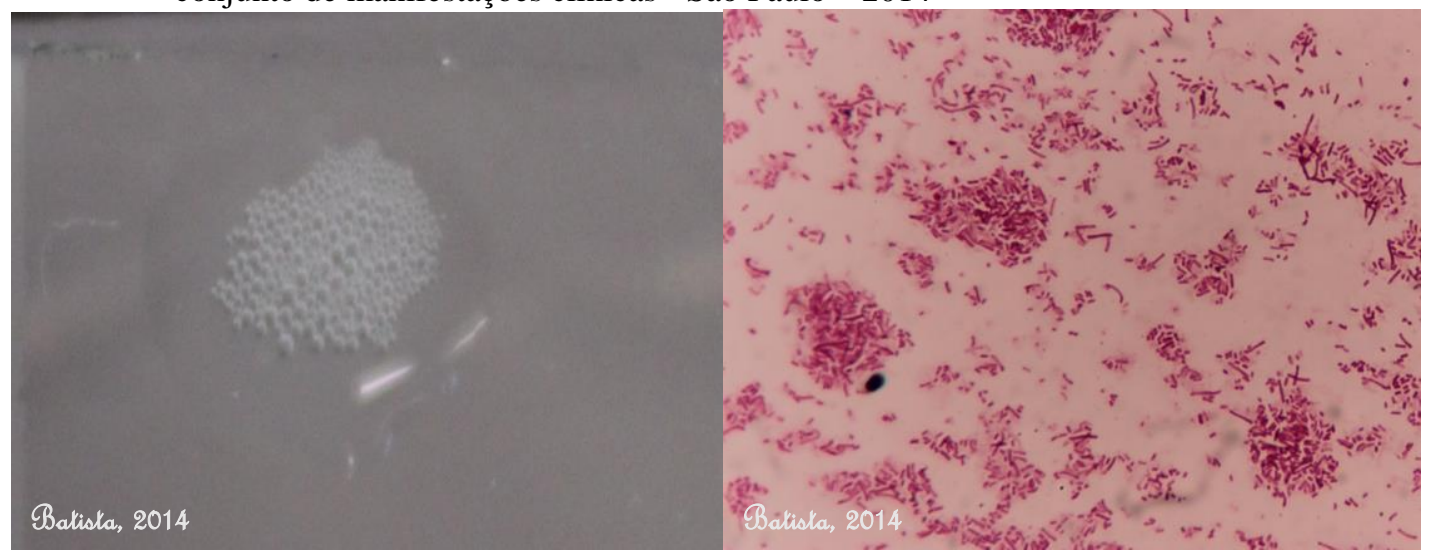

Figura 4 - Teste API identificando a bactéria recuperada dos animais inoculados como Mannheimia haemolytica, após surgimento do conjunto de manifestações clínicas. (Foto superior pré incubação, foto inferior após $24 \mathrm{~h}$ à $37^{\circ} \mathrm{C}$ de incubação com a bactéria recuperada de bezerro) - São Paulo - 2014

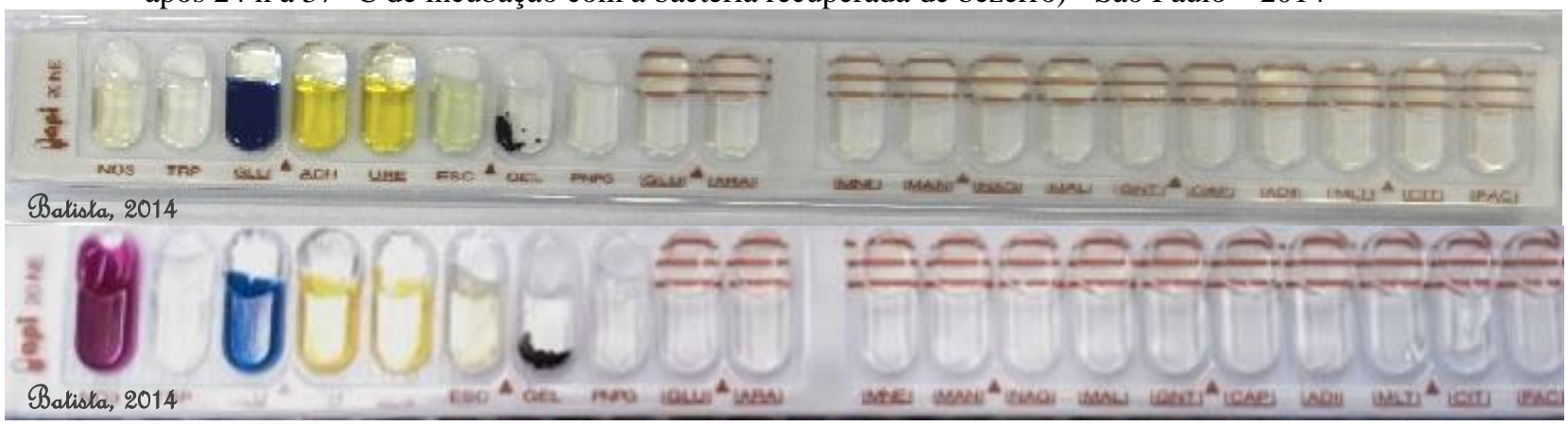


As colônias recuperadas foram submetidas ao teste do antibiograma ${ }^{4}$ para determinar a sensibilidade bacteriana, e auxiliar na escolha do tratamento. A bactéria foi sensível a todos os antimicrobianos utilizados para o teste (enrofloxacina $5 \mu \mathrm{g}$, norfloxacina $10 \mu \mathrm{g}$, penicilina 10 $\mathrm{U}$, sulfametatoxazol + trimetropima $25 \mu \mathrm{g}$, ceftiofur $30 \mu \mathrm{g}$, cefalexina $30 \mu \mathrm{g}$, amoxicilina + ácido clavulânico $30 \mu \mathrm{g}$, ampicilina $10 \mu \mathrm{g}$ ). Diante de tal resultado, foi escolhido para o tratamento o antimicrobiano à base de norfloxacina, pois estava disponível em quantidade suficiente do mesmo lote para o tratamento total e por ser indicado como agente terapêutico de doenças respiratórias.

As amostras recuperadas da primeira passagem nos bezerros foram utilizadas para o preparo do inóculo dos doze bezerros utilizados na pesquisa. Os inóculos foram preparados no dia da indução e aplicados imediatamente após o término do preparo.

\subsection{ANIMAIS UTILIZADOS E DELINEAMENTO EXPERIMENTAL}

Foram utilizados doze bezerros machos da raça Holandesa preta e branca, com seis meses de idade, com boa condição de saúde ao exame físico, hematológico e parasitológico e provenientes de propriedades leiteiras localizadas no Estado de São Paulo.

Os animais receberam dois kg de ração peletizada por dia, um fardo de feno de tyfton divididos em duas alimentações, sal mineral e água ad libitum. Foram pesados, examinados clinicamente e monitorados periodicamente durante o estudo, de acordo com os momentos experimentais (Quadro 1).

Manteve-se os animais em baias medindo 2,80 m de largura, por 3,60 $\mathrm{m}$ de comprimento, com piso emborrachado. A limpeza do local era realizada diariamente e repetida sempre que necessário.

Avaliou-se a função imune local e sistêmica em quatro momentos, conforme descrito no quadro 1. As amostras de lavado broncoalveolar (LBA), foram submetidas à quantificação das populações leucocitárias, avaliação funcional das células fagocíticas, ensaio de viabilidade celular e citologia. Nas amostras de sangue procedeu-se a quantificação das populações leucocitárias, avaliação funcional das células fagocíticas, ensaio de viabilidade celular e hemograma.

\footnotetext{
${ }^{4}$ Sensifar-Vet Cefar ${ }^{\circledR}$ Discos para antibiograma
} 
Quadro 1 - Momentos das coletas, exames realizados e material coletado dos 12 bovinos durante o período da pesquisa

\begin{tabular}{|c|c|c|c|c|c|}
\hline Momento & M1 ( $1^{a}$ coleta $)$ & Inoculação & M2 ( $2^{\mathrm{a}}$ coleta $)$ & M3 $\left(3^{\mathrm{a}}\right.$ coleta $)$ & M4 $\left(4^{\text {a }}\right.$ coleta $)$ \\
\hline Dia & $\begin{array}{l}\text { Dois dias antes } \\
\text { da inoculação }\end{array}$ & $\begin{array}{l}\text { Mesmo dia } \\
\text { do M2 }\end{array}$ & $\begin{array}{c}\text { Após } \\
\text { manifestações } \\
\text { clínicas* }\end{array}$ & $\begin{array}{c}1 \text { dia após } \\
\text { término da } \\
\text { antibioticoterapia }\end{array}$ & $\begin{array}{l}1 \text { semana após o } \\
\text { término da } \\
\text { antibioticoterapia }\end{array}$ \\
\hline \multirow{6}{*}{$\begin{array}{l}\text { Material } \\
\text { coletado }\end{array}$} & Exame Físico & \multirow{6}{*}{$\begin{array}{l}\text { Exame } \\
\text { Físico }\end{array}$} & Exame Físico & Exame Físico & Exame Físico \\
\hline & Broncoscopia & & Broncoscopia & Broncoscopia & Broncoscopia \\
\hline & LTB & & - & LTB & LTB \\
\hline & Suabe & & Suabe & Suabe & Suabe \\
\hline & LBA & & LBA & LBA & LBA \\
\hline & Sangue & & Sangue & Sangue & Sangue \\
\hline
\end{tabular}

*Apatia, dispnéia, alteração nos ruídos respiratórios, hipertermia, elevação das frequências cardíaca e respiratória e arritmia cardíaca de acordo com Fagliari (2003).

Os animais foram distribuídos aleatoriamente, por sorteio, em dois grupos experimentais, com seis animais cada, descritos a seguir: Grupo 1 (G1): animais tratados com norfloxacina e antiinflamatório (flunixina meglumina na dose de 2,2 mg/kg, SID por 3 dias) e Grupo 2 (G2): Animais tratados exclusivamente com norfloxacina (na dose de $5 \mathrm{mg} / \mathrm{kg}$, por 7 dias, SID). O tratamento foi iniciado logo após as coletas do M2, ou seja, após as manifestações clínicas surgirem.

\subsubsection{Exames físico e específico do sistema respiratório}

O exame físico dos animais foi realizado utilizando-se os métodos semiológicos classicamente preconizados por Dirksen, Grunder e Stober (1993), no qual foram avaliadas as funções vitais constituídas por frequências respiratória e cardíaca, temperatura corporal, estado de hidratação, coloração das mucosas aparentes e palpação de linfonodos.

Posteriormente, foi realizado o exame específico do sistema respiratório, com o emprego dos diferentes meios semiológicos como a inspeção, palpação, percussão, auscultação e olfação (GONÇALVES; FEITOSA, 2008). 


\subsubsection{Inspeção indireta por broncoscopia}

A inspeção indireta do sistema respiratório foi realizada de acordo com Thrunavukkarasu et al. (2005) e Batista (2011), por meio de broncoscopia, utilizando um videocolonoscópio flexível ${ }^{5}$, com 11,0 mm de diâmetro e comprimento de trabalho de 1.600 $\mathrm{mm}$, acoplado a uma processadora de imagens com fonte de luz ${ }^{6}$.

\subsection{COLETA DAS AMOSTRAS}

As amostras de lavado broncoalveolar, lavado traqueobrônquico, suabe nasal e sangue venoso foram coletadas de acordo com o descrito a seguir.

\subsubsection{Lavado traqueobrônquico}

Nos momentos M1, M3 e M4 antes da realização da inspeção indireta e da coleta do LBA, foi realizado o LTB com o intuito de colher amostras sem contaminação externa para caracterizar a população bacteriana presente no trato respiratório dos animais nesses momentos. Não foi coletado o LTB no momento M2, pois os animais haviam sido puncionados horas antes para a inoculação da bactéria, evitando maiores desconfortos aos animais.

O LTB foi realizado de acordo com Benesi et al. (2012, 2013), com um cateter ${ }^{7}$ introduzido no espaço entre dois anéis traqueais do terço anterior da traqueia; $20 \mathrm{~mL}$ de solução fisiológica estéril foi infundido e aspirado com pressão para recuperar o material contido principalmente em região traqueal.

Esse material foi cultivado por 24 horas em caldo ICC a $37^{\circ} \mathrm{C}$ em estufa, e em seguida transferido para placas de ACC com $5 \%$ de sangue de carneiro e mantidos em estufa por mais 24 horas a $37^{\circ} \mathrm{C}$. As colônias foram identificadas e caracterizadas.

\footnotetext{
${ }^{5}$ EC-250LP5, Fujinon ${ }^{\circledR}$

${ }^{6}$ System 2200 Processador, Fujinon ${ }^{\circledR}$

${ }^{7}$ BD Intracath Cateter Intravenoso Central ${ }^{\circledR}$ CAT: 785900
} 


\subsubsection{Suabe nasal}

Para complementar os resultados dos lavados traqueobrônquicos foi obtido em todos os momentos suabe nasal dos animais de acordo com Coutinho et al. (2009). Esse material foi cultivado por 24 horas em caldo ICC a $37^{\circ} \mathrm{C}$ e em seguida semeado em placas de ACC com 5 $\%$ de sangue de carneiro por mais 24 horas, a $37{ }^{\circ} \mathrm{C}$. As colônias foram identificadas e caracterizadas.

\subsubsection{Lavado broncoalveolar (LBA)}

Durante a inspeção indireta por endoscopia foi realizado o lavado broncoalveolar (LBA) (BATISTA, 2011).

Após a inspeção do aparelho respiratório foi injetado através do canal de trabalho do endoscópio, $80 \mathrm{~mL}$ de solução fisiológica estéril. Em seguida esse material foi aspirado pelo próprio canal de trabalho, com auxílio de um aspirador ${ }^{8}$, recuperando-se aproximadamente, $60 \mathrm{~mL}$ de LBA.

O material coletado foi acondicionado em dois frascos estéreis cônicos, de $50 \mathrm{~mL}$, para quantificação e identificação de células leucocitárias do LBA, avaliação funcional dos fagócitos, ensaio de viabilidade celular e citologia do LBA. O segundo frasco foi destinado para a quantificação da expressão de citocinas.

\subsubsection{Isolamento da suspensão celular das amostras de LBA}

No laboratório, as amostras de LBA foram centrifugadas ${ }^{9}$ a 1.000 x $g$ por 15 minutos, em centrífuga refrigerada $\left(4{ }^{\circ} \mathrm{C}\right)$. Após a centrifugação, desprezou-se o sobrenadante e, o botão celular foi ressuspendido, em aproximadamente $30 \mathrm{~mL}$ de $\operatorname{PBS}^{10}$. A centrifugação foi repetida desta vez a 400 x $g$ por 10 minutos $\left(4{ }^{\circ} \mathrm{C}\right)$. Após desprezar o sobrenadante, as

\footnotetext{
${ }^{8}$ Aspiramax Suction device compacto MA-520 ${ }^{\circledR}$ - NS Indústria de Aparelhos Médicos Ltda.

${ }^{9}$ Eppendorf ${ }^{\circledR}$ Centrifuge 5810R

${ }^{10}$ Phosphate Buffered Saline - Tampão Fosfato Salino
} 
células foram ressuspendidas em 1 mL de RPMI 1640 enriquecido com SFB 10 \% (KOESS; HAMANN, 2008).

O frasco com LBA destinado à dosagem de citocinas foi centrifugado da mesma forma, apenas diferenciando-se as lavagens que foram realizadas com PBS estéril. O botão celular foi ressuspendido em $1 \mathrm{~mL}$ de RPMI 1640, enriquecido com SFB $10 \%$ e adicionados a tubos estéreis livres de RNAse. Centrifugou-se novamente para a remoção do meio (10.000 x $g$ por 8 minutos à $4{ }^{\circ} \mathrm{C}$ ) e dissolveu-se as células em $500 \mu \mathrm{L}$ de Trizol $^{\mathrm{TM}}$ reagente $^{11}$, mantendo-as congeladas a $-80^{\circ} \mathrm{C}$ até o processamento do RNA, por um período máximo de 2 meses.

4.3.3.2 Viabilidade e concentração celular das amostras de LBA

A suspensão celular foi submetida à contagem e determinação da viabilidade celular, realizada na câmara de Neubauer, avaliada pela exclusão do azul de Trypan. Em seguida, a suspensão celular foi ajustada para $2 \times 10^{6}$ células viáveis $/ \mathrm{mL}$, para a realização das provas imunológicas e citológicas.

\subsubsection{Citologia do LBA}

As células foram recuperadas de acordo com o protocolo descrito nos itens 4.3.3.1 e 4.3.3.2 Após o ajuste da concentração celular, $200 \mu \mathrm{L}$ da suspensão foram centrifugadas, utilizando uma citocentrífuga ${ }^{12}$, a $28 \times \mathrm{g}$, por 6 minutos. As lâminas foram fixadas em Metanol P.A. durante cinco minutos, e coradas com corante de Rosenfeld.

Para a contagem diferencial das células do LBA, utilizou-se um microscópio óptico, e um contador automático Leucotron ${ }^{\circledR}$ T-P. Foram contadas 300 células, em um aumento de 1000x com óleo de imersão. As células foram diferenciadas entre monócitos, macrófagos, macrófagos binucleados, células gigantes, neutrófilos segmentado, linfócitos, basófilos, eosinófilos, de acordo com Gonçalves (1997).

\footnotetext{
${ }^{11}$ Invitrogen Corp., SP, BRA

${ }^{12}$ Cytospin 3 SHANDON ${ }^{\circledR}$
} 


\subsubsection{Coleta de Sangue e análise hematológica}

Para a realização do hemograma foram colhidas amostras de sangue por venopunção da jugular utilizando tubos tipo vacuntainer estéreis contendo EDTA como anticoagulante. O número total de leucócitos e de eritrócitos por $\mathrm{mL}$ foi mensurado através de contador automático de partículas ${ }^{13}$. A contagem diferencial foi feita em esfregaços sanguíneos corados com corante de Rosenfeld; para a diferenciação do padrão leucocitário ao microscópio óptico ${ }^{14}$, com objetiva de imersão, sendo identificados e contados 100 leucócitos, conforme metodologia descrita por Birgel (1982).

\subsection{AVALIAÇÃO IMUNOLÓGICA DO LBA}

Os ensaios para quantificação das populações de mononucleares, avaliação da produção intracelular de ERO e de fagocitose por leucócitos do LBA foram realizados por citometria de fluxo ${ }^{15}$, conforme as técnicas empregadas por Hasui, Hirabayashi e Kobayashi (1989).

Para a realização do ensaio de fagocitose e do modelo de tratamento in vitro, foi necessária a conjugação da M. haemolytica (ATCC 33396) à R-Phycoerythrin ${ }^{16}$.

\subsubsection{Conjugação da Mannheimia haemolytica à R-Phycoerythrin (R-PE)}

Uma amostra da bactéria foi cultivada, a $37^{\circ} \mathrm{C}$, por 24 horas em caldo ICC, e posteriormente semeada em placas de Petri contendo $\mathrm{ACC}^{17} \mathrm{com} 5 \%$ de sangue desfibrinado de carneiro, e então incubadas a $37^{\circ} \mathrm{C}$, por mais 24 horas. Após o crescimento bacteriano, as colônias foram coletadas com suabe estéril e transferidas para tubos cônicos de $15 \mathrm{~mL}$,

\footnotetext{
${ }^{13}$ ABC Vet ${ }^{\circledR}$ Marca ABX ${ }^{\mathrm{TM}}$ HORIBA, Montpellier, França

${ }^{14}$ Nikon $^{\circledR}$ ECLIPSE E200

${ }^{15}$ FACSCalibur $^{\mathrm{TM}}$ - Becton Dickinson Immunocytometry System ${ }^{\mathrm{TM}}$, San Diego, EUA.

${ }^{16}$ Thermo Scientific, Rockford, EUA, n ${ }^{\circ}$ cat. 46185.

17 BD DIFCOTM, Franklin Lakes, EUA, n ${ }^{\circ}$ cat. 241830.
} 
contendo solução salina isotônica estéril, sendo então centrifugadas a $1.100 \mathrm{x} g$ por 10 minutos. Ao término da centrifugação, os tubos foram colocados em banho maria à $60^{\circ} \mathrm{C}$, por 60 minutos, para inativar as bactérias. Após este período o sobrenadante foi desprezado e uma alíquota foi retirada para realização da contagem das UFC. Em seguida, o botão bacteriano foi ressuspendido em solução salina isotônica estéril. O processo de centrifugação e de lavagem foi repetido mais duas vezes e, os frascos foram armazenados à $4{ }^{\circ} \mathrm{C}$, até a leitura da placa de UFC, para confirmação da inativação bacteriana.

Confirmada a inativação da amostra, a sua absorbância foi mensurada em comprimento de onda de $620 \mathrm{~nm}$, para obter a concentração estimada de 2,4x10 $\mathrm{UFC} / \mathrm{mL}$, equivalente à concentração ajustada na escala 08 de Mac Farland ${ }^{18}$.

Adicionou-se aos frascos com as bacterias inativadas, $160 \mu \mathrm{L}$ de $R$-Phycoerythrin, para cada $20 \mathrm{~mL}$ de cultivo. Incubou-se à temperatura ambiente, overnight, sob agitação constante e sob ausência de luminosidade.

Após 24 horas, os tubos foram centrifugados a 10.000 x $g$ por 5 minutos, o botão foi ressuspendido em $20 \mathrm{~mL}$ de solução HBSS estéril e novamente lavado. O procedimento foi repetido duas vezes e por fim, o botão bacteriano foi ressuspendido em $20 \mathrm{~mL}$ de solução HBSS estéril, e as amostras foram divididas em frascos âmbar e estocadas a $-80^{\circ} \mathrm{C}$.

Ensaios para confirmar a conjugação da bactéria a $R$-Phycoerythrin foram realizados com sucesso por citometria de fluxo (Figura 5).

${ }^{18}$ Escala Nefelométrica de Mac Farland, NEFELOBAC, Probac do Brasil. 
Figura 5 - Demonstração da intensidade de fluorescência da bactéria Mannheimia haemolytica não conjugada à $R$-Phycoeritrin (à esquerda em preto) e conjugada à $R$-Phycoeritrin (à direita em laranja) verificada pela citometria de fluxo - São Paulo - 2014

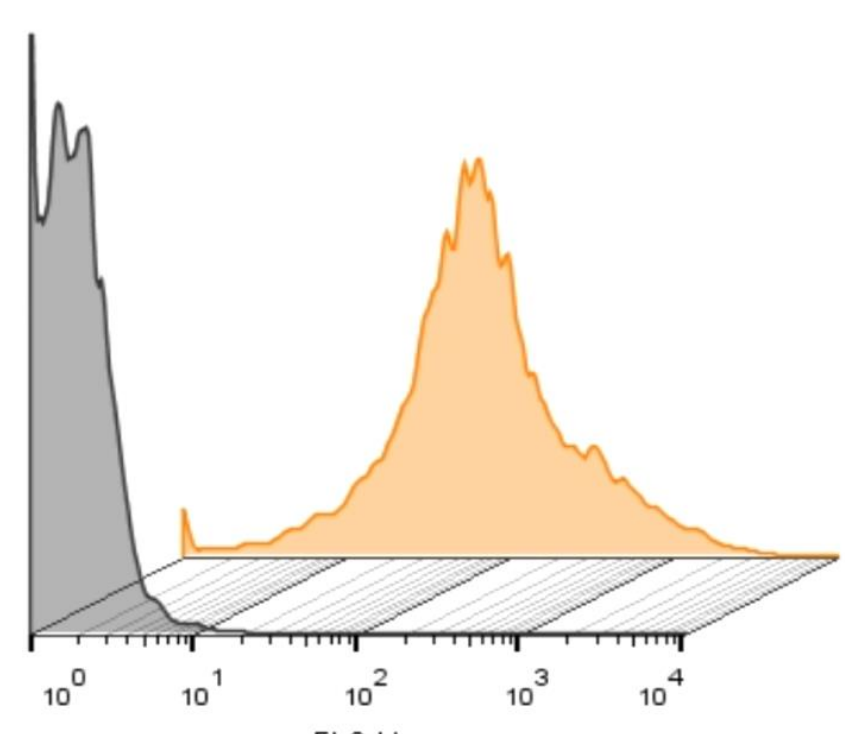

\begin{tabular}{|l|l|r|}
\hline & \multicolumn{1}{|c|}{ Sample Name } & Count \\
\hline$\square$ & sem marcacao.002 & 10000 \\
\hline$\square$ & Marcada centrifugada.00 & 10000 \\
\hline
\end{tabular}

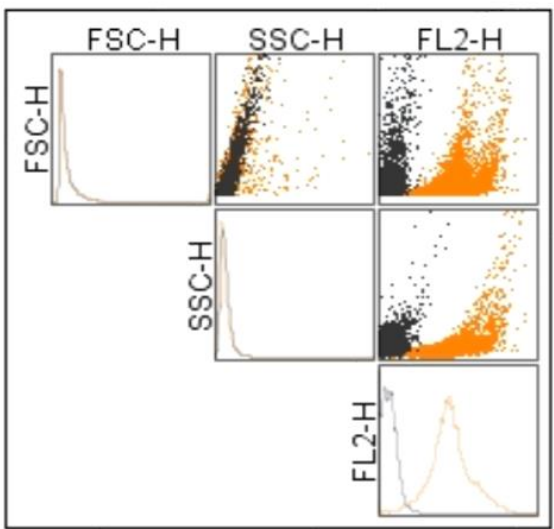

FL2-H

FONTE: Batista, 2014

\subsubsection{Avaliação funcional dos fagócitos do LBA}

Os ensaios foram realizados em tubos de polipropileno próprios para citometria de fluxo. Em cada tubo foi adicionado $100 \mu \mathrm{L}$ de suspensão celular do LBA $\left(2 \times 10^{5}\right.$ células viáveis) de cada animal e incubado ${ }^{19}$ a $37{ }^{\circ} \mathrm{C}$, por 30 minutos, com $200 \mu \mathrm{L}$ de 2',7' diclorodihidrofluoresceína diacetato $(\text { DCFH-DA })^{20}(0,3 \mathrm{mM})$, para avaliar a produção intracelular de ERO.

Para realização das provas de fagocitose, a esses tubos foram adicionados $2 \mu \mathrm{L}$ de $S$. aureus $^{21}$ (multiplicidade de infecção - MOI 24:1 bactérias:célula) ou E. coli ${ }^{22}$ (MOI 24:1 bactérias:célula), conjugados com Alexa 594, ou $125 \mu \mathrm{L}$ de $M$. haemolytica conjugada com R-PE (MNH) (MOI 25:1 bactérias:célula) (Quadro 2). Após o período de incubação, as reações foram interrompidas pela adição de $2.000 \mu \mathrm{L}$ de solução gelada de ácido etilenodiamino tetra-acético (EDTA) (3 mM). Em seguida os tubos foram centrifugados a 250 $\mathrm{x} g$, por oito minutos. Posteriormente procedeu-se a imunofenotipagem.

\footnotetext{
${ }^{19}$ Banho-Maria - Modelo 102, Marca Fanen Ltda ${ }^{\circledR}$ - São Paulo - SP.

${ }^{20}$ Sigma Aldrich, St. Louis, ${ }^{\circ}$ cat. D6883

${ }^{21}$ Life, San Diego, CA, USA, n ${ }^{\circ}$ cat. S23372
} 


\subsubsection{Quantificação e identificação de células mononucleares do LBA}

O ensaio de identificação dos fagócitos do LBA foi realizado juntamente com a avaliação funcional, de acordo com o Quadro 2. Após centrifugar e desprezar o sobrenadante, foi adicionado aos tubos, $1 \mu \mathrm{L}$ do anticorpo monoclonal primário, permanecendo por 30 minutos à temperatura ambiente. Passado o período de incubação foram adicionados $1.000 \mu \mathrm{L}$ de PBS gelado e, nova centrifugação foi realizada. O sobrenadante foi descartado e $1 \mu \mathrm{L}$ do anticorpo monoclonal secundário foi adicionado e, os tubos foram mantidos em temperatura ambiente, no escuro por 30 minutos. Procedeu-se mais uma lavagem e as amostras foram ressuspendidas em $400 \mu \mathrm{L}$ de solução gelada de PBS+BSA e mantidas no escuro, para a leitura no citômetro de fluxo.

Quadro 2 - Anticorpos monoclonais primários e secundários (por tubo) para quantificação da produção intracelular de espécies reativas de oxigênio, fagocitose e imunofenotipagem das amostras de LBA no Citômetro de fluxo (FACSCalibur ${ }^{\mathrm{TM}}$ ) - São Paulo - 2014

\begin{tabular}{|c|c|}
\hline \multicolumn{2}{|r|}{ Calibração } \\
\hline Tubo & Conteúdo \\
\hline A & Só células \\
\hline B & DCFH \\
\hline $\mathrm{C}$ & MNH-PE \\
\hline $\mathrm{D}$ & CD14-IgG123 + IgG1-PECy-5 ${ }^{24}$ \\
\hline $\mathrm{E}$ & E.coli-Alexa 594 \\
\hline \multicolumn{2}{|r|}{ Experimento Lavado } \\
\hline $\mathrm{F}$ & CD14-IgG1+ IgG1-PECy-5 + DCFH \\
\hline G & CD14-IgG1+ IgG1-PECy-5 + DCFH + MNH-PE \\
\hline $\mathrm{H}$ & CD14-IgG1+ IgG1-PECy-5 + DCFH + S. aureus-Alexa 594 \\
\hline I & CD14-IgG1+ IgG1-PECy-5 + DCFH + E.coli-Alexa 594 \\
\hline $\mathrm{J}$ & CD3-IgG1 $1^{25}+$ IgG1-FITC ${ }^{26}+$ CD4-IgG2a ${ }^{27}+$ IgG2a-PE $^{28}+$ CD8-IgM ${ }^{29}+$ IgM-APC $^{30}$ \\
\hline K & CD45-IgG1PECy5 ${ }^{31}+$ CD14-IgG1 ${ }^{16}+\operatorname{IgG1}$-FITC \\
\hline
\end{tabular}

FONTE: Batista, 2014

DCFH - diacetato de 2,7-Diclorodihidrofluoresceína; FITC - Isotiocianato de fluoresceína; PECy5 - Ficoeritrina-Cianina 5; APC - Aloficocianina; PE - Ficoeritrina; MNH - Mannheimia haemolytica

\footnotetext{
${ }^{22}$ Life, San Diego, CA, USA, n cat. E23370

${ }^{23}$ VMRD, Pullman, USA, ${ }^{\circ}$ cat. MM61A

${ }^{24}$ Life, San Diego, CA, USA, $n^{\circ}$ cat. M32018

${ }^{25}$ VMRD, Pullman, USA, $n^{\circ}$ cat. MM1A

${ }^{26}$ Life, San Diego, CA, USA, n ${ }^{\circ}$ cat. A10530

${ }^{27}$ VMRD, Pullman, USA, ${ }^{\circ}$ cat. ILA11A

${ }^{28}$ Life, San Diego, CA, USA, n ${ }^{\circ}$ cat. M32204

${ }^{29}$ VMRD, Pullman, USA, $n^{\circ}$ cat. BAQ11A

${ }^{30}$ Life, San Diego, CA, USA, $n^{\circ}$ cat. M31505

${ }^{31}$ AbD Serotec, Oxfford, UK, ${ }^{\circ}$ cat. MCA2804C
} 


\subsubsection{Ensaio de Viabilidade Celular}

No ensaio para a avaliação da viabilidade celular empregou-se a Anexina V-FITC ${ }^{32}$ e o iodeto de propídio. Estes procedimentos foram conduzidos segundo as técnicas empregadas por Vermes, Haanen e Reutelingsperger (2000).

Foram adicionados $100 \mu \mathrm{L}$ de suspensão celular e $1.000 \mu \mathrm{L}$ de tampão de ligação ${ }^{33}$ em todos os tubos. Posteriormente, as amostras foram submetidas à centrifugação em 250 x $g$ por 8 minutos e ressuspendidas em $100 \mu \mathrm{L}$ de solução de tampão de ligação, com $1 \mu \mathrm{L}$ Anexina V-FITC. Em seguida, as amostras foram incubadas por 20 minutos à temperatura ambiente e protegidas da luminosidade, e o tubo B (Quadro 3) foi incubado pelo mesmo tempo, a $56{ }^{\circ} \mathrm{C}$. Foram adicionados aos tubos $1.000 \mu \mathrm{L}$ de tampão de ligação, para posterior centrifugação em 250 x g, por 8 minutos. Após desprezar o sobrenadante, adicionou-se 100 $\mu \mathrm{L}$ de tampão de ligação juntamente com os respectivos anticorpos, de acordo com o protocolo descrito no quadro 3.

Adicionou-se $1 \mu \mathrm{L}$ do anticorpo primário e incubou-se por 30 minutos, em temperatura ambiente. Em seguida acrescentou-se $1.000 \mu \mathrm{L}$ de tampão de ligação e procedeuse nova centrifugação, em 250 x $g$, por 8 minutos. Realizou-se a ressuspensão em $100 \mu \mathrm{L}$ de tampão de ligação e adicionou-se $1 \mu \mathrm{L}$ do anticorpo secundário, incubando-se por 30 minutos em temperatura ambiente, sob a ausência da luminosidade, para subsequentemente adicionar $1.000 \mu \mathrm{L}$ de tampão de ligação em cada tubo e centrifugar a $250 \mathrm{x} g$, por 8 minutos. Procedeu-se mais uma lavagem e as amostras foram ressuspendidas em $400 \mu \mathrm{L}$ de solução gelada de PBS+BSA e mantidas no escuro, para a leitura no citômetro de fluxo. As amostras foram analisadas em quadrantes, onde o quadrante inferior esquerdo representava as células viáveis, o superior esquerdo as células em apoptose, o inferior direito as células em necrose e o superior direito as células duplo positivas (necrose tardia ou apoptose secundária) (BLAGITZ, 2011).

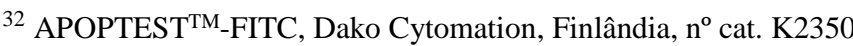

${ }^{33} 10 \mathrm{mM}$ Hepes/150 mM NaCl/ $1 \mathrm{mM} \mathrm{MgCl} 2 / 1,8 \mathrm{mM} \mathrm{CaCl} 2$
} 
Quadro 3 - Anticorpos monoclonais primários e secundários (por tubo) para realização do ensaio de viabilidade celular das amostras de lavado broncoalveolar no Citômetro de fluxo (FACSCalibur ${ }^{\mathrm{TM}}$ ) - São Paulo - 2014

\begin{tabular}{|c|c|}
\hline \multicolumn{2}{|c|}{ Calibração } \\
\hline Tubo & Conteúdo \\
\hline A & Só células \\
\hline B & Anexina \\
\hline C & PI \\
\hline D & CD14-IgG1 $16+I g G 1-$ PE $^{34}$ \\
\hline \multicolumn{2}{|c|}{ Sxperimento Lavado } \\
\hline E & Só células \\
\hline
\end{tabular}

FONTE: Batista, 2014

PI - Iodeto de Propídeo; PE - Ficoeritrina

\subsection{AVALIAÇÃO IMUNOLÓGICA DAS AMOSTRAS DE SANGUE}

Os ensaios para quantificação das populações de leucócitos sanguíneos, avaliação da produção intracelular de ERO e de fagocitose por leucócitos do sangue foram realizados por citometria de fluxo ${ }^{35}$, conforme as técnicas empregadas por Hasui, Hirabayashi e Kobayashi (1989).

\subsubsection{Avaliação funcional dos fagócitos}

Os ensaios foram realizados em tubos de polipropileno próprios para citometria de fluxo. Em cada tubo foi adicionado $100 \mu \mathrm{L}$ de sangue de cada animal e incubado ${ }^{36}$ a $37{ }^{\circ} \mathrm{C}$, por 30 minutos, com $200 \mu \mathrm{L}$ de 2',7' diclorodihidrofluoresceína diacetato (DCFH-DA) ${ }^{37}(0,3$ $\mathrm{mM})$, para avaliar a produção intracelular de ERO.

Para realização das provas de fagocitose, a esses tubos foram adicionados $2 \mu \mathrm{L}$ de $S$. aureus (MOI 24:1 bactérias:célula) ou E. coli (MOI 24:1 bactérias:célula) conjugados com Alexa 594, e $125 \mu \mathrm{L}$ de $M$. haemolytica conjugada (MOI 25:1 bactérias:célula) com R-PE $(\mathrm{MNH})$, de acordo com o protocolo descrito no Quadro 4. Após o período de incubação, as

\footnotetext{
${ }^{34}$ Life, San Diego, CA, USA, n cat. P21129

${ }^{35}$ FACSCalibur $^{\mathrm{TM}}$ - Becton Dickinson Immunocytometry System ${ }^{\mathrm{TM}}$, San Diego, EUA.

${ }^{36}$ Banho-Maria - Modelo 102, Marca Fanen Ltda® - São Paulo - SP.

${ }^{37}$ Sigma Aldrich, St. Louis, nº cat. D6883
} 
reações foram interrompidas pela adição de $2.000 \mu \mathrm{L}$ de solução gelada de ácido etilenodiamino tetra-acético (EDTA) (3 mM); em seguida os tubos foram centrifugados a 250 $\mathrm{x} g$, por oito minutos. Após desprezar o sobrenadante e homogeneizar as amostras, procedeuse a lise hipotônica das hemácias com solução salina $(0,2 \%$ e 1,6 \%) e nova centrifugação. Em seguida foram adicionados os anticorpos para a identificação das populações leucocitárias.

\subsubsection{Quantificação e identificação dos leucócitos sanguíneos}

O ensaio de identificação dos leucócitos do sangue foi realizado juntamente com a avaliação funcional, de acordo com o Quadro 4. Após centrifugar e desprezar o sobrenadante, foi adicionado aos tubos, $1 \mu \mathrm{L}$ do anticorpo monoclonal primário, permanecendo por 30 minutos à temperatura ambiente. Passado o período de incubação, foram adicionados 1.000 $\mu \mathrm{L}$ de PBS gelado e nova centrifugação foi realizada. O sobrenadante foi descartado e $1 \mu \mathrm{L}$ do anticorpo monoclonal secundário foi adicionado e, os tubos foram mantidos em temperatura ambiente, no escuro, por 30 minutos. Procedeu-se mais uma lavagem e as amostras foram ressuspendidas em $400 \mu \mathrm{L}$ de solução gelada de PBS+BSA e, mantidas no escuro, para a leitura no citômetro de fluxo. No tubo M, após esse procedimento, foi realizada a incubação em temperatura ambiente, no escuro, por 30 minutos, com o anticorpo conjugado CD14-PECy5. 
Quadro 4 - Anticorpos monoclonais primários e secundários (por tubo) para realização da quantificação da produção intracelular de espécies reativas de oxigênio, fagocitose e imunofenotipagem das amostras de sangue no citômetro de fluxo (FACSCalibur ${ }^{\mathrm{TM}}$ ) São Paulo - 2014

\begin{tabular}{|c|c|}
\hline \multicolumn{2}{|c|}{ Calibração } \\
\hline Tubo & Conteúdo \\
\hline A & Só células \\
\hline B & DCFH \\
\hline C & MNH-PE \\
\hline D & CD14-IgG1 ${ }^{16}+$ IgG1-PECy-5 ${ }^{17}$ \\
\hline E & CH138-IgM ${ }^{29}+$ IgM-APC \\
\hline F & E.coli-Alexa 594 ${ }^{15}$ \\
\hline & Experimento Sangue \\
\hline G & CD14-IgG1+ IgG1-PECy-5 + CH138-IgM + IgM-APC + DCFH \\
\hline H & CD14-IgG1+ IgG1-PECy-5 + CH138-IgM + IgM-PE ${ }^{38}+$ E.coli-Alexa 594 + CD62L-FITC \\
\hline I & CD14-IgG1+ IgG1-PECy-5 + CH138-IgM + IgM-APC + DCFH + MNH-PE \\
\hline J & CD14-IgG1+ IgG1-PECy-5 + CH138-IgM + IgM-PE + DCFH + S.aureus-Alexa 594 \\
\hline K & CD14-IgG1+ IgG1-PECy-5 + CH138-IgM + IgM-PE + DCFH + E.coli-Alexa 594 \\
\hline L & CD3-IgG1 + IgG1-FITC + CD4-IgG2a + IgG2a-PE + CD8-IgM + IgM-APC \\
\hline M & CD45-IgG1 + IgG1-PECy5 + CD14-IgG1 + IgG1-FITC + CH138-IgM + IgM-APC \\
\hline
\end{tabular}

FONTE: Batista, 2014

DCFH - diacetato de 2,7-Diclorodihidrofluoresceína; FITC - Isotiocianato de fluoresceína; PECy5 - Ficoeritrina-Cianina 5; APC - Aloficocianina; PE - Ficoeritrina; MNH - Mannheimia haemolytica

\subsubsection{Ensaio de viabilidade celular}

Com as amostras de sangue realizou-se o mesmo procedimento descrito no tópico 4.4.4, diferenciando-se apenas pela ausência de lise hipotônica das hemácias. Os anticorpos foram adicionados aos tubos, de acordo com o Quadro 5.

\footnotetext{
${ }^{38}$ Life, San Diego, CA, USA, ${ }^{\circ}$ cat. M31504
}

${ }^{39}$ AbD Serotec, Oxfford, UK, ${ }^{\circ}$ cat. MCA1649F 
Quadro 5 - Anticorpos monoclonais primários e secundários (por tubo) para realização do ensaio de viabilidade celular das amostras de sangue no citômetro de fluxo (FACSCalibur ${ }^{\mathrm{TM}}$ ) - São Paulo - 2014

\begin{tabular}{|c|c|}
\hline \multicolumn{2}{|c|}{ Calibração } \\
\hline Tubo & Conteúdo \\
\hline A & Só células \\
\hline B & Anexina \\
\hline C & PI \\
\hline D & CD14-IgG1 + IgG1-PE \\
\hline E & CH138-IgM + IgM-APC \\
\hline \multicolumn{2}{|c|}{ Experimento Sangue } \\
\hline F & Só células \\
\hline G & Anexina + PI + CD14-IgG1 + IgG1-PE + CH138-IgM + IgM-APC \\
\hline
\end{tabular}

FONTE: Batista, 2014

APC - Aloficocianina; PE - Ficoeritrina; PI - Iodeto de Propídeo

\subsection{DESAFIO FUNCIONAL IN VITRO}

No momento M1, alíquotas das amostras de LBA e de sangue dos mesmos animais do estudo, foram submetidas aos protocolos de fagocitose e de produção de ERO, com o intuito de verificar a interação in vitro do antimicrobiano selecionado, para o tratamento dos animais.

As amostras foram processadas de acordo com o descrito nos itens 4.4.2 e 4.5.1, porém, para cada tubo preparado para as provas, existia um outro respectivo, que recebeu adição do antimicrobiano a ser utilizado no tratamento dos animais, conforme dose utilizada por Hoeben et al. (1997) e Dosogne et al. (1998).

O antimicrobiano norfloxacina foi diluído em RPMI na proporção de 1/100 e, em cada tubo designado para receber o antimicrobiano, foi adicionado $100 \mu \mathrm{L}$ dessa solução, procedendo todo o protocolo, até a sua leitura no citômetro. 


\subsection{ANÁLISE DA CITOMETRIA DE FLUXO}

As leituras das amostras foram realizadas em citômetro de fluxo ${ }^{40}$ conectado a um computador $^{41}$, com o programa CELLQUEST ${ }^{\circledR 42}$. Foram adquiridos 10.000 eventos de cada tubo e os dados obtidos nas leituras da citometria de fluxo foram analisados em software próprio $\left(\right.$ Flow $\left.\mathrm{Jo}^{43}\right)$, após o termino das coletas.

Nas amostras de LBA, para a localização da população de leucócitos alveolares, o gráfico gerado pelo CELLQUEST ${ }^{\circledR}$, foi inicialmente analisado pelo tamanho (FSC) e granulosidade (SSC) (LOHMEYER et al., 1994; RAIDAL; BAILEY; LOVE, 1998; BATISTA et al., 2012) (Figura 6). Após identificar e selecionar a população de macrófagos, foram identificados os macrófagos com expressão do CD14 (PE-Cy5) por meio da intensidade de fluorescência média (IMF), obtida em escala logarítmica e, emitida no comprimento de onda 670/LP nm (FL3) (Figura 7).

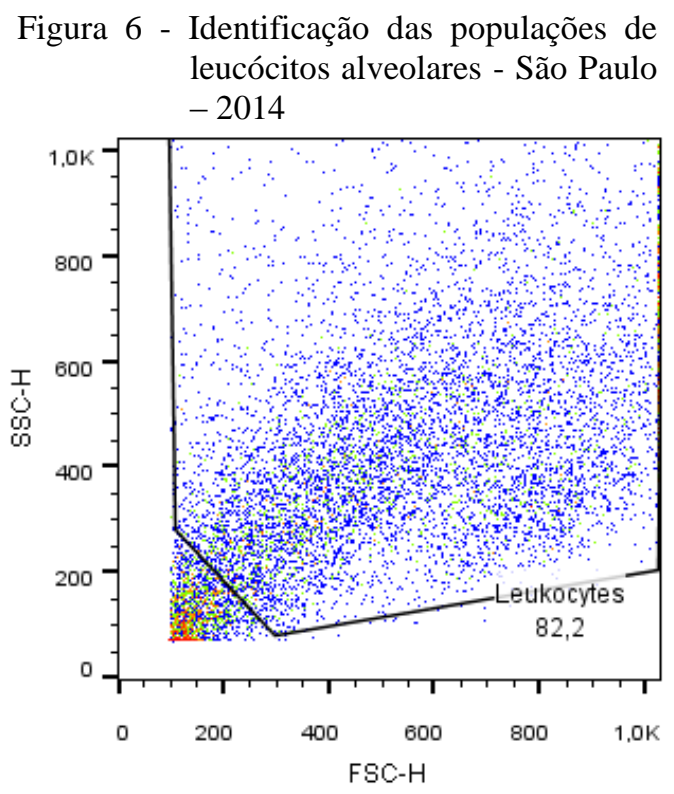

\footnotetext{
${ }^{40}$ FACSCalibur $^{\mathrm{TM}}$.

${ }^{41}$ Macintosh Apple, CA, USA

${ }^{42}$ Becton Dickinson Immunocytometry Systems ${ }^{\mathrm{TM}}$.

${ }^{43}$ Treestar - Versão vX.0.7 para Windows.
} 
Figura 7 - Identificação das populações de macrófagos alveolares expressando
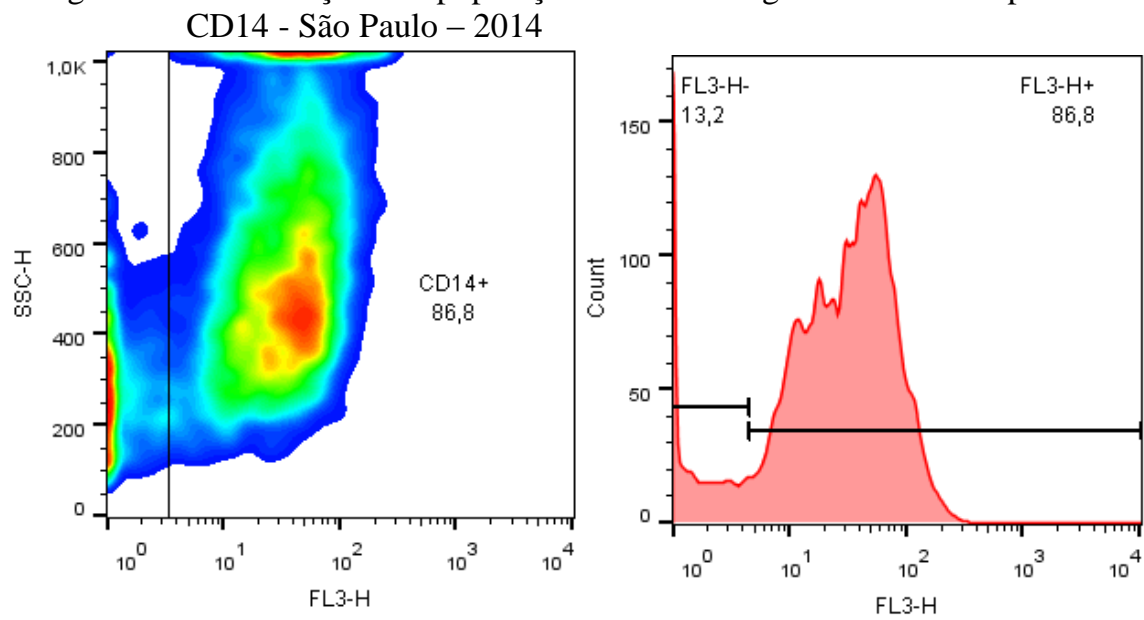

Obtiveram-se os valores de produção de ERO intracelular e de fagocitose dentro da população identificada expressando CD14 nas amostras de LBA.

A avaliação da produção de ERO intracelular foi mensurada através da intensidade de fluorescência obtida após a oxidação do DCFH a DCF, em escala logarítmica e, no comprimento de onda $530 \pm 30 \mathrm{~nm}$ (FL1) (Figura 8).

A fagocitose foi medida através da emissão da fluorescência no comprimento de onda 617 nm (FL4) pelo Alexa 594 e, no comprimento 578 nm, pelo R-PE (FL2) (Figura 9).

Figura 8 - Macrófagos alveolares expressando CD14 que produziram espécies reativas de oxigênio intracelular - São Paulo - 2014
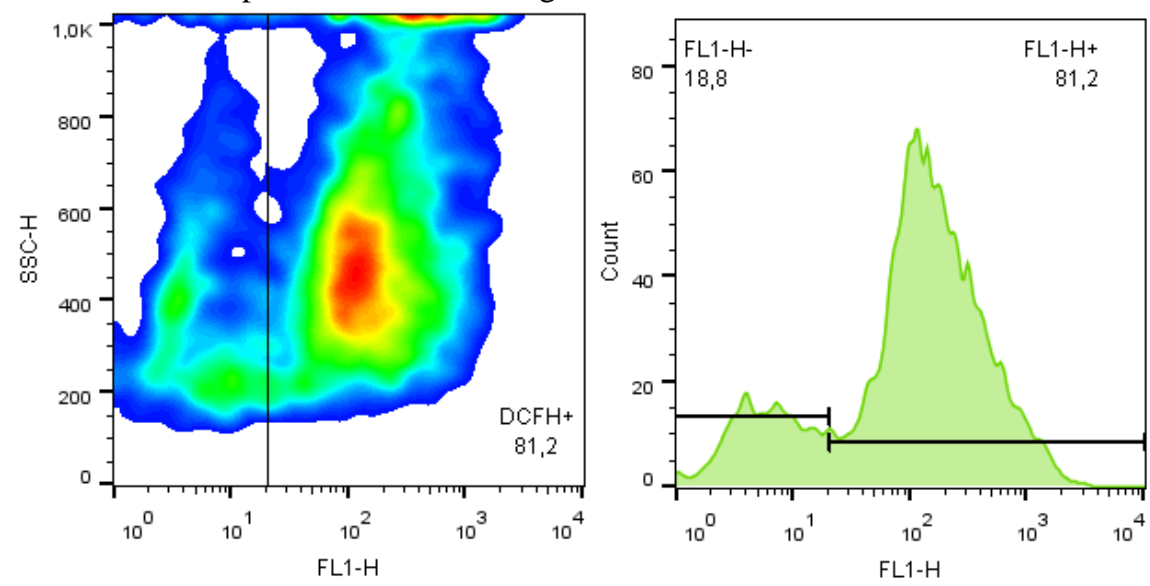
Figura 9 - Macrófagos alveolares expressando CD14 que produziram espécies reativas de oxigênio intracelular (FL1) e fagocitaram bactérias (A- Mannheimia haemolytica (FL2); B- Staphylococcus aureus; C- Escherichia coli (FL4)) - São Paulo - 2014

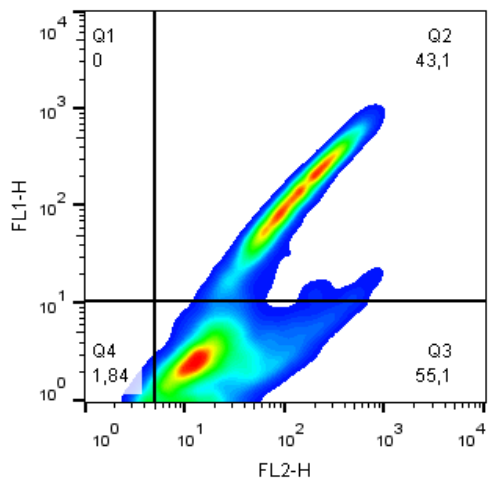

A

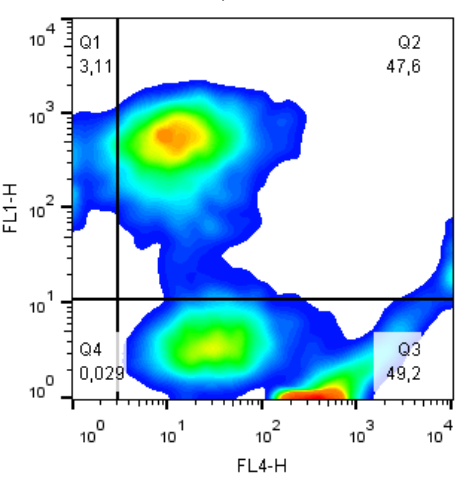

B

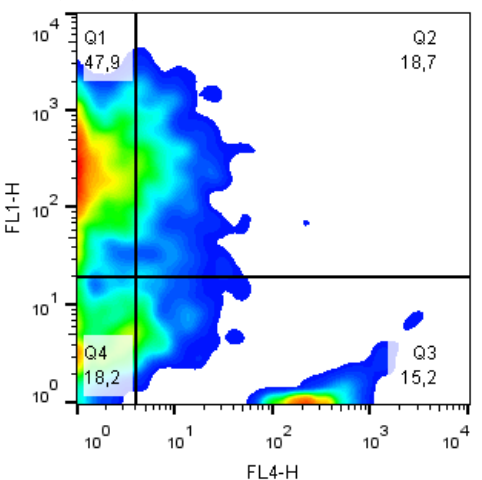

$\mathrm{C}$

Para as amostras de sangue realizou-se o mesmo processo, diferenciando-se apenas a marcação das células granulocíticas pelo $\mathrm{CH} 138$ e a análise das funções celulares nessa população.

Inicialmente identificou-se a população de leucócitos mononucleares e granulócitos (Figura 10). Confirmou-se a seguir a população de granulócitos pela expressão de CH138 (APC para os ensaios com M. haemolytica e R-PE para os ensaios com S. aureus e E. coli) (Figura 11). Verificou-se suas funções pela produção de intracelular de ERO (Figura 12) e pela fagocitose (Figura 13. Identificou-se os leucócitos que expressam o CD14 (PE-Cy5) (Figura 14), aferiu-se suas funções tanto na produção intracelular de ERRO (Figura 15) quanto na fagocitose (Figura 16).

Figura 10 - Identificação das populações de granulócitos e mononucleares do sangue de bezerros - São Paulo - 2014

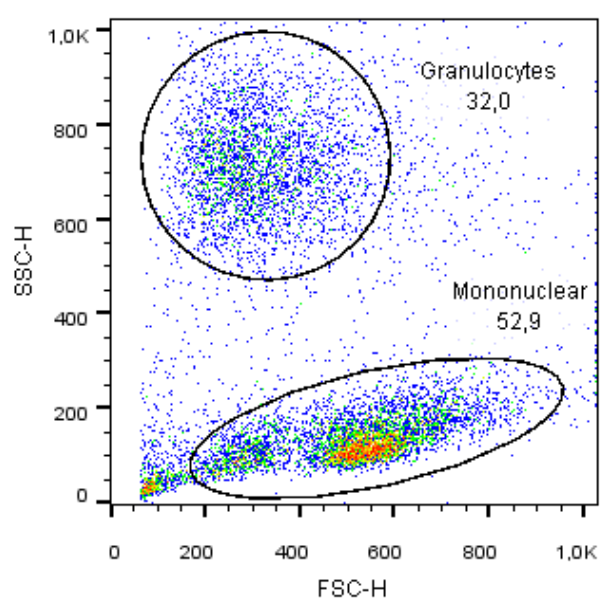


Figura 11 - Identificação das populações de granulócitos sanguíneos expressando CH138 - São Paulo - 2014
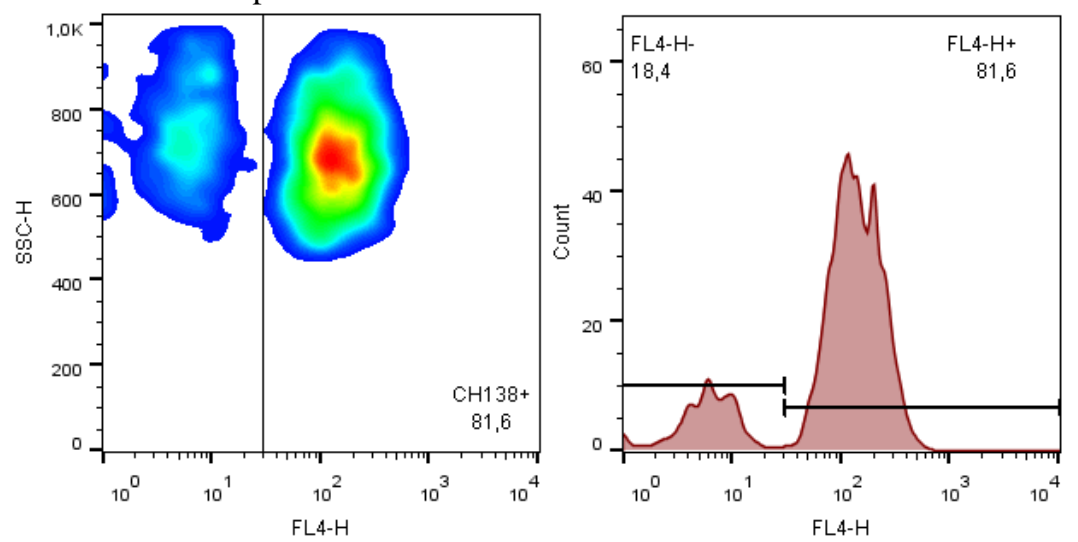

Figura 12 - Granulócitos sanguíneos expressando CH138 que produziram espécies reativas de oxigênio intracelular. São Paulo - 2014
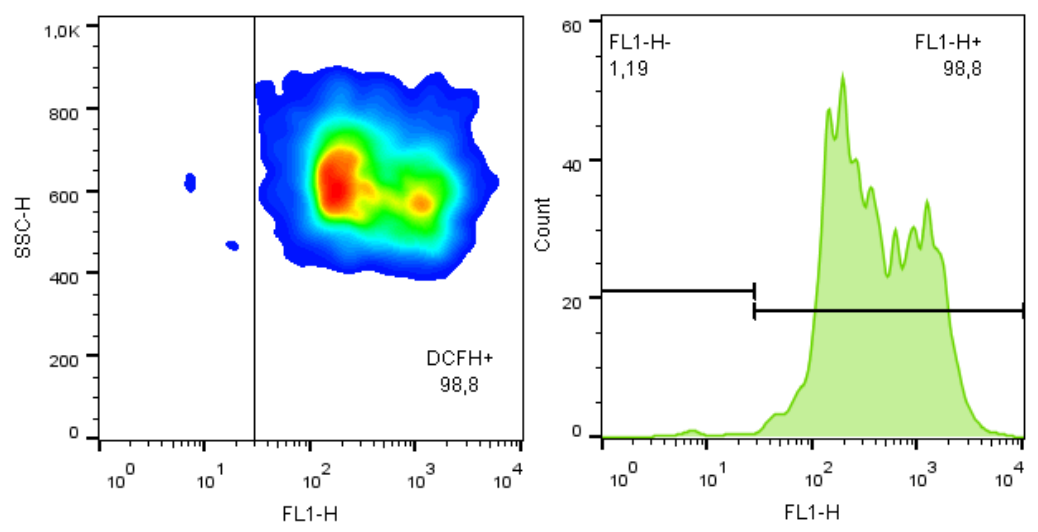

Figura 13 - Granulócitos sanguíneos expressando CH138 que produziram espécies reativas de oxigênio intracelular (FL1) e fagocitaram bactérias (A- Mannheimia haemolytica (FL2); B-Staphylococcus aureus; C- Escherichia coli (FL4)) - São Paulo - 2014

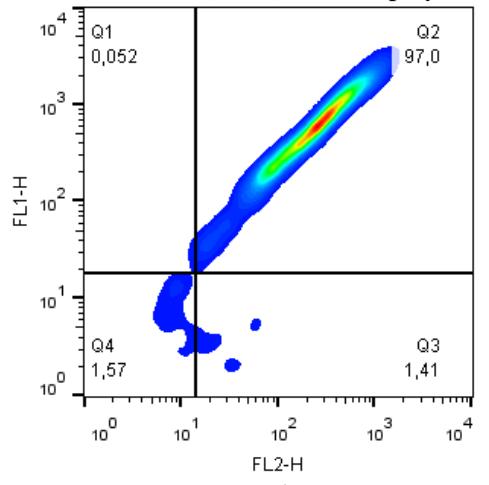

A

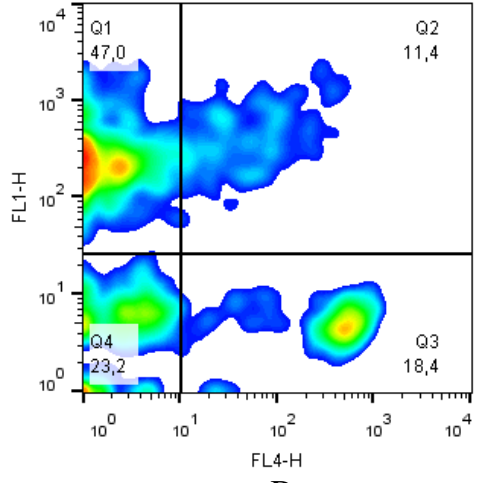

B

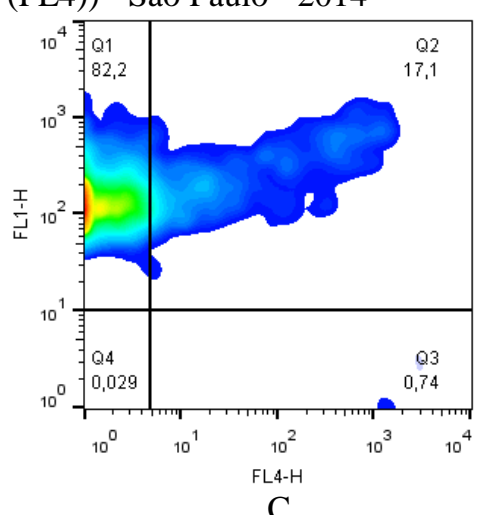

$\mathrm{C}$ 
Figura 14 - Identificação das populações de monócitos sanguíneos expressando CD14 - São Paulo - 2014
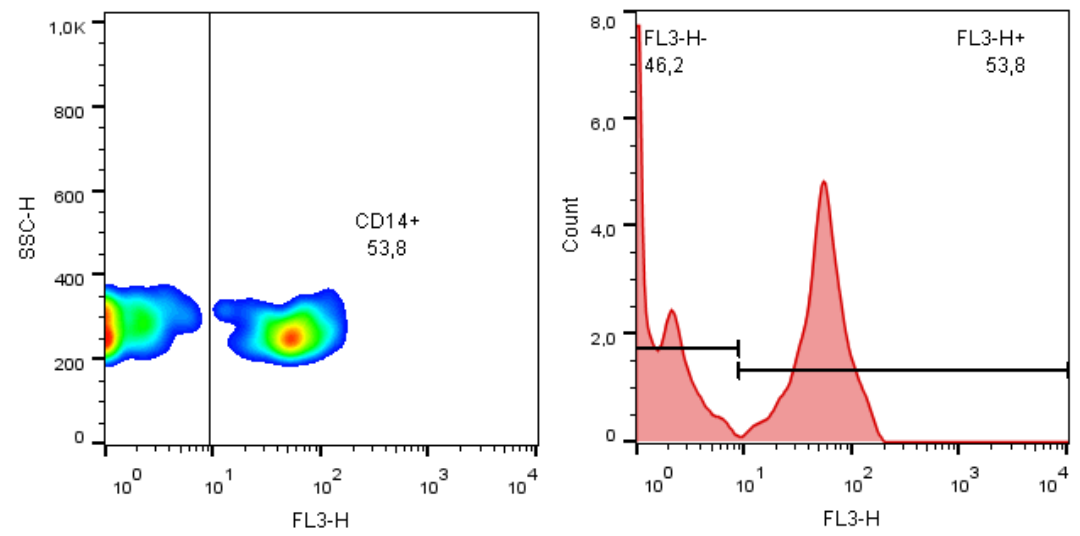

Figura 15 - Monócitos sanguíneos expressando CD14 que produziram espécies reativas de oxigênio intracelular - São Paulo - 2014
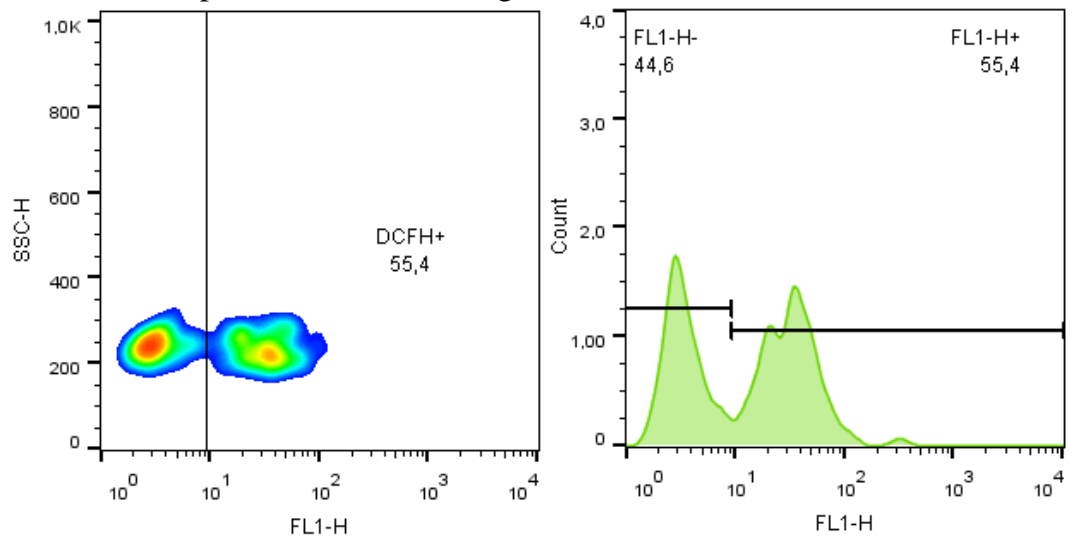

Figura 16 - Monócitos sanguíneos expressando CD14 que produziram espécies reativas de oxigênio intracelular (FL1) e fagocitaram bactérias (A- Mannheimia haemolytica (FL2); B-Staphylococcus aureus; C- Escherichia coli (FL4)) - São Paulo - 2014

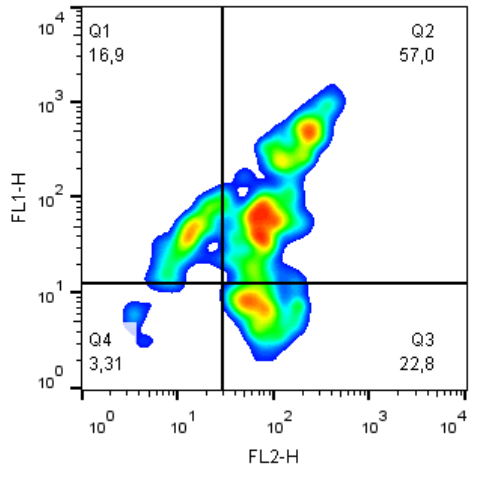

A

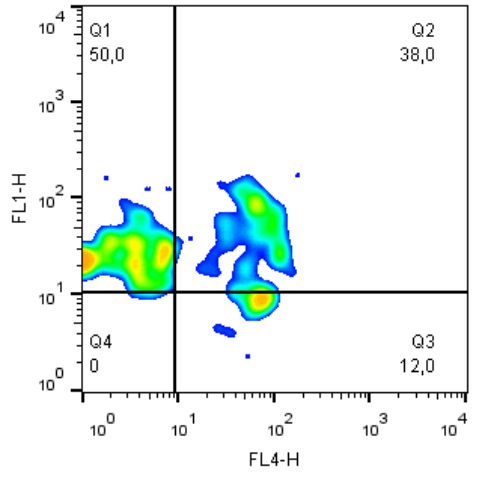

B

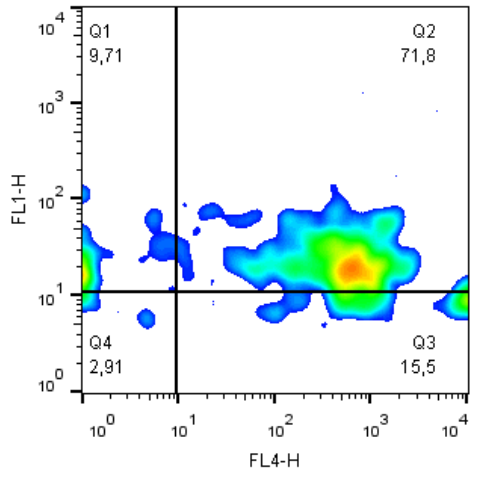

$\mathrm{C}$ 


\subsection{EXPRESSÃO DE CITOCINAS EM CÉLULAS SANGUÍNEAS E} BRONCOALVEOLARES VERIFICADAS POR PCR EM TEMPO REAL

Para as quantificações da expressão de citocinas nas células sanguíneas, amostras de sangue periférico dos doze animais, nos quatro momentos experimentais, foram coletadas em tubos tipo vacuntainer estéreis, contendo heparina como anticoagulante. A mesma análise foi realizada nas amostras de LBA coletadas por broncoscopia, como descrito no item 4.3.3.

\subsubsection{Processamento laboratorial}

Após a coleta do sangue e do lavado broncoalveolar, as amostras foram submetidas a centrifugação $\left(700 \times \mathrm{g}\right.$ por $15 \mathrm{~min}$, a $4{ }^{\circ} \mathrm{C}$ ) para a separação dos leucócitos, tanto do sangue quanto do LBA.

A partir deste momento todos os procedimentos foram realizados em fluxo laminar, utilizando materiais e soluções estéreis e livres de RNAse. O LBA foi centrifugado mais uma vez com PBS estéril, sob a mesma centrifugação.

O botão leucocitário foi acondicionado em tubos cônicos de $15 \mathrm{~mL}$, sofrendo lise osmótica das hemácias ainda presentes na amostra, no caso das amostras de sangue. Posteriormente lavou-se os leucócitos com $1 \mathrm{~mL}$ de meio de cultura RPMI 1640, e após centrifugação ${ }^{44}\left(2.000 \times \mathrm{g}\right.$ por $8 \mathrm{~min}$, a $\left.4^{\circ} \mathrm{C}\right)$, congelou-se o botão leucocitário em $500 \mu \mathrm{L}$ de Trizol $^{\mathrm{TM}}$ Reagente ${ }^{45}$, à temperatura de $-80{ }^{\circ} \mathrm{C}$, até a extração de RNA, por até um período máximo de 2 meses de congelamento.

\footnotetext{
${ }^{44}$ Eppendorf 5417R

${ }^{45}$ Invitrogen Corp., SP, BRA
} 


\subsubsection{Extração de RNA e síntese de DNA complementar}

A extração de RNA total foi realizada utilizando kits específico de extração ${ }^{46}$, conforme instrução do fabricante. Posteriormente, a pureza e a concentração do RNA foram avaliadas por espectrofotometria ${ }^{47}$, estando o grau de pureza entre 1,7 a 2,0, quando utilizada a razão entre as bandas 260 e 280 e concentração média de $40 \mathrm{ng} / \mu \mathrm{L}$. Devido ao baixo grau de pureza, (ideal 2,0) optou-se por se tratar as amostras por meio de digestão de DNA com a enzima DNAse, utilizando Kit comercial $^{48}$ de acordo com as instruções do fabricante. Posteriormente, utilizou-se $7 \mu \mathrm{L}$ do RNA total para sintetizar o DNA complementar, pela técnica de transcriptase reversa, utilizando kit comercial para pequenas quantidades ${ }^{49}$ obtendo-se $20 \mu \mathrm{L}$ de solução total.

\subsubsection{PCR quantitativo em tempo real por transcriptase reversa (RT- qPCR)}

A PCR quantitativa foi realizada de acordo com a técnica previamente descrita por Kabara et al. (2014) utilizando ensaios de expressão gênica da Applied Biosystems, sendo os primers pré desenhados (TNF- $\alpha^{50}$; IL-1 $\beta^{51}$; IL- $8^{52}$ ). As amostras foram analisadas em duplicatas, utilizando $20 \mathrm{ng}$ de DNA por reação $(2,5 \mu \mathrm{L}), 10 \mu \mathrm{L}$ de tampão $0^{53}$ e $0,5 \mu \mathrm{L}$ dos respectivos ensaios de expressão gênica ${ }^{54}$, em equipamento para $\mathrm{qPCR}^{55}$. A amplificação de PCR foi realizada em placas óticas de 96 poços. Para as detecções, o equipamento de qPCR foi programado para 2 ciclos iniciais de 2 minutos, a $50{ }^{\circ} \mathrm{C}$ e 10 minutos, a $95{ }^{\circ} \mathrm{C}$, seguido por 40 ciclos de 15 segundos, a $95{ }^{\circ} \mathrm{C}$ e finalizando, com um ciclo de 1 minuto, a $60{ }^{\circ} \mathrm{C}$.

A eficiência da reação (E) foi calculada a partir de curvas padrão para cada gene, usando a fórmula $\mathrm{E}=\mathrm{e}(-1 /$ slope $)-1)$, sendo estes resultados IL-1 $\beta$ - $83 \%$, IL-8 - 120 \%; TNF-

\footnotetext{
${ }^{46}$ RNA Purelink mini kit, Life Tech., SP, BRA

${ }^{47}$ Nanodrop 1000, Thermo Scientific, Wilmington, DE

${ }^{48}$ DNAse I grau amplificação, Invitrogen Corp., SP, BRA

${ }^{49}$ Sensiscript RT KIT, Qiagen, SP, BRA

${ }^{50}$ Bt 03259156_m1, Applied Biosystem, SP, BRA

${ }^{51}$ Bt 03212474_m1, Applied Biosystem, SP, BRA

52 Bt 03211906_m1, Applied Biosystem, SP, BRA

53 TaqMan Fast Universal PCR Master Mix, Applied Biosystem, SP, BRA

54 TaqMan Gene Expression Assay Mix -20x, Applied Biosystem, SP, BRA

557500 Real Time PCR System, Applied Biosystem, SP, BRA
} 
$\alpha-84 \%$, GAPDH - 88\%, para amostras sanguíneas e IL-1 $\beta$ - $83 \%$, IL-8 - $80 \%$; TNF- $\alpha$ - 83 $\%$, GAPDH - $88 \%$, para amostras do LBA.

A relativa quantificação de TNF- $\alpha$, IL-8 e IL-1 $\beta$ foram calculadas utilizando o software 7500 SDS (v.1.3.1). Os resultados foram calculados baseados na razão da expressão relativa de cada gene, corrigida pela eficiência da reação (PFAFFL; HORGAN; DEMPFLE, 2002), utilizando GAPDH ${ }^{56}$ como gene de referência (HOLMGREN et al., 2014; KABARA et al., 2014) e calibrado, utilizando a média dos valores obtidos do M1 de cada gene.

\subsection{ANÁLISE ESTATÍSTICA}

As análises estatísticas foram realizadas utilizando o software estatístico GraphPad InStat $^{\circledR}$, versão 3.01 para Windows $95^{57}$.

Foi verificada a normalidade da distribuição dos resultados, utilizando-se o teste de Kolmogorov-Smirnov (SAMPAIO, 1998).

Para a avaliação das diferenças entre os grupos aplicou-se o teste t-Student para os dados com distribuição normal, e para dados que não apresentaram distribuição normal, analisou-se os dados pelo teste de Mann-Whitney (SAMPAIO, 1998).

Para a avaliação das diferenças entre os momentos dentro de cada grupo, aplicou-se o teste Repeated Measures ANOVA seguido pelo pós teste de Tukey, para os dados com distribuição normal. Para os dados não paramétricos aplicou-se o Teste de Friedmann seguido pelo pós teste de Dunn's. Para todos os resultados, foram consideradas significativas as análises que apresentaram $\mathrm{P} \leq 0,05$ aos testes estatísticos acima mencionados (SAMPAIO, 1998).

\footnotetext{
${ }^{56}$ Bt 032109113-g1, Applied Biosystem, SP, BRA

${ }^{57}$ GraphPad Software, Inc., San Diego California USA
} 
OResultados 


\section{RESULTADOS}

Os resultados das análises imunológicas do sangue e do sistema respiratório e dos exames clínicos e complementares dos bezerros estão apresentados em tabelas e gráficos a seguir.

\subsection{EXAMES FÍSICO GERAL E ESPECÍFICO DO SISTEMA RESPIRATÓRIO}

A avaliação dos resultados do exame físico dos bezerros permitiu verificar a presença de manifestações clínicas que permitissem identificar enfermidades do sistema respiratório dos animais, evidentes no momento M2 (momento do surgimento das manifestações clínicas) (Quadro 6); o tempo para evidenciar essas alterações variou entre 15 e 18 horas após a inoculação. Até o momento da coleta, os animais eram examinados de hora em hora, e ao longo dos exames pode-se notar a evolução das alterações, até o estabelecimento do quadro clínico.

Quadro 6 - Manifestações clínicas observadas durante o estabelecimento do quadro clínico de mannheimiose após indução experimental de pneumonia por Mannheimia haemolytica - São Paulo - 2014

\begin{tabular}{|c|c|c|}
\hline Manifestação & Animais acometidos \% (n) & Observações \\
\hline Aumento de linfonodos & $66,67 \%(8 / 12)$ & Submandibulares e cervicais superficiais \\
\hline Mucosas avermelhadas & $41,67 \%(5 / 12)$ & Oculares e palpebrais \\
\hline Secreção Nasal Seromucosa & $100 \%(12 / 12)$ & Figura 17 \\
\hline Tosse espontânea & $50 \%(6 / 12)$ & $\begin{array}{c}\text { Porém todos apresentaram tosse quando } \\
\text { estimulados }\end{array}$ \\
\hline Respiração abdominal & $41,67 \%(5 / 12)$ & Em dois tempos (bater de flancos) \\
\hline Muflo Seco & $100 \%(12 / 12)$ & \\
\hline Frêmito & $33,33 \%(4 / 12)$ & A palpação do tórax \\
\hline Areas de submacicez & $83,33 \%(10 / 12)$ & A percussão do tórax \\
\hline Estertores úmidos & $100 \%(12 / 12)$ & $\begin{array}{l}\text { Por meio de auscultação torácica, } \\
\text { variando apenas a localização do ruído }\end{array}$ \\
\hline Odor Pútrido & $8,33 \%(1 / 12)$ & Na olfação \\
\hline $\begin{array}{l}\text { Diminuição da motilidade } \\
\text { Ruminal }\end{array}$ & $100 \%(12 / 12)$ & Em alguns casos chegando à atonia \\
\hline Fezes amolecidas & $100 \%(12 / 12)$ & \\
\hline
\end{tabular}

Todos os animais apresentaram prostração e alteração de atitude durante o quadro clínico. Todas essas manifestações involuíram durante a semana de tratamento, chegando à remissão da sintomatologia no momento M4. 
Figura 17 - Presença de secreção seromucosa durante o quadro broncopneumônico - São Paulo - 2014

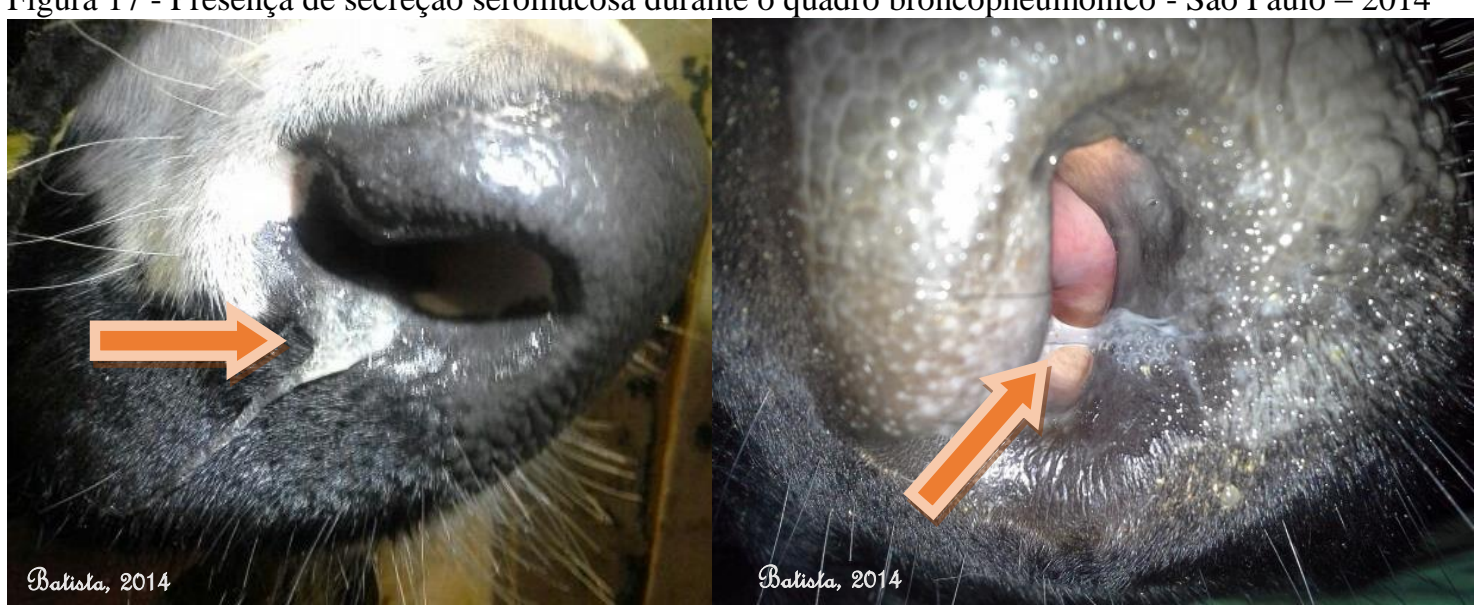

Na Tabela 1 estão dispostos os valores médios e erros padrão das frequência cardíaca, frequência respiratória e temperatura retal dos bezerros em relação aos momentos experimentais.

Tabela 1 - Médias e erros padrão das funções vitais: temperatura retal, frequência de movimentos respiratórios e frequência de batimentos cardíacos de bezerros durante os quatro momentos da infecção experimental por M. haemolytica - São Paulo - 2014

\begin{tabular}{|c|c|c|c|c|c|c|}
\hline \multirow[t]{2}{*}{ Tempo } & \multicolumn{2}{|c|}{ Frequência Cardíaca/min } & \multicolumn{2}{|c|}{$\begin{array}{c}\text { Frequência } \\
\text { Respiratória/min }\end{array}$} & \multicolumn{2}{|c|}{ Temperatura Retal $\left({ }^{\circ} \mathrm{C}\right)$} \\
\hline & G1 & G2 & G1 & G2 & G1 & G2 \\
\hline \multirow{2}{*}{ M1 } & $85,00^{\mathrm{Aa}}$ & $84,00^{\mathrm{Aa}}$ & $39,66^{\mathrm{Aa}^{*}}$ & $32,00^{\mathrm{Aa}}$ & $39,06^{\mathrm{Aa}}$ & $39,06^{\mathrm{ABa}}$ \\
\hline & $( \pm 5,45)$ & $( \pm 6,61)$ & $( \pm 2,55)$ & $( \pm 3,09)$ & $( \pm 0,19)$ & $( \pm 0,13)$ \\
\hline \multirow{2}{*}{ M2 } & $90,83^{\text {Aa }}$ & $84,16^{\mathrm{Aa}}$ & $59,33^{\text {Aa* }^{*}}$ & $50,33^{\mathrm{Ba}}$ & $39,81^{\mathrm{Ba}}$ & $39,65^{\mathrm{Ba}}$ \\
\hline & $( \pm 6,47)$ & $( \pm 6,17)$ & $( \pm 7,67)$ & $( \pm 6,50)$ & $( \pm 0,22)$ & $( \pm 0,27)$ \\
\hline \multirow{2}{*}{ M3 } & $89,33^{\mathrm{Aa}}$ & $94,00^{\mathrm{Aa}}$ & $49,33^{\mathrm{Aa}}$ & $34,66^{\mathrm{Aa}}$ & $39,03^{\mathrm{Aa}}$ & $39,16^{\mathrm{ABa}}$ \\
\hline & $( \pm 3,21)$ & $( \pm 2,25)$ & $( \pm 6,33)$ & $( \pm 2,86)$ & $( \pm 0,06)$ & $( \pm 0,13)$ \\
\hline \multirow{2}{*}{ M4 } & $91,33^{\mathrm{Aa}}$ & $90,66^{\text {Aa }}$ & $42,66^{\mathrm{Aa}}$ & $38,66^{\mathrm{ABa}}$ & $39,06^{\mathrm{Aa}}$ & $38,83^{\mathrm{Aa}}$ \\
\hline & $( \pm 2,99)$ & $( \pm 2,86)$ & $( \pm 1,68)$ & $( \pm 2,66)$ & $( \pm 0,09)$ & $( \pm 0,12)$ \\
\hline $\mathbf{P}$ & 0,82 & 0,22 & 0,06 & 0,01 & 0,008 & 0,04 \\
\hline
\end{tabular}

M1: Antes da inoculação, M2: Momento das manifestações clínicas, M3: Um dia após o fim do tratamento, M4: Uma semana após o fim do tratamento

G1: norfloxacina associada a flunixina meglumina; G2: somente norfloxacina

Letras Maiúsculas diferentes indicam $\mathrm{P} \leq 0,05$ entre os momentos experimentais.

Letras Minúsculas diferentes indicam $\mathrm{P} \leq 0,05$ entre os grupos.

$* \mathrm{P}=0,06$ indica tendência entre os momentos

Em relação as frequências respiratórias dos animais, houve maior frequência no M2 em relação à M1 e M3 no G2, já no G1 não se observou diferença, mas houve tendência. Não foi observada diferença entre os grupos nos diferentes momentos. 
Os valores médios da temperatura retal do G2 foram maiores no M2 em relação M4. No G1 observou-se maior temperatura retal no M2 em relação aos demais tempos. Em relação aos grupos, não foi observada diferença em nenhum dos momentos.

\subsubsection{Inspeção indireta}

Durante a broncoscopia observou-se as características normais do aparelho respiratório dos bezerros sadios (M1), e em M2, identificou-se alterações características do quadro pneumônico (Figura 18).

Animais sadios apresentam mucosas traqueais e bronquiais rosadas, brilhantes, vasos quase inaparentes e ausência de secreção. Durante o quadro pneumônico, os animais apresentaram grande quantidade de secreção fibrinonecrótica, de coloração que variou do amarelo palha até o esverdeado (Figura 19), a mucosa da traqueia e dos brônquios apresentava-se congesta de coloração avermelhada e com os vasos ingurgitados e bem evidentes (Figura 20); a presença do endoscópio em todo o trajeto do sistema respiratório demonstrava desconforto aos animais, pois esses apresentavam episódios de tosse durante o exame, o que não ocorreu durante o exame dos animais sem pneumonia. Alguns animais apresentaram edema das mucosas em todo o trato respiratório.

Figura 18 - $Q R$ code representativo do vídeo da evolução do quadro durante os quatro momentos da infecção experimental por Mannheimia haemolytica (https://youtu.be/xqsy2bTIj

s8).

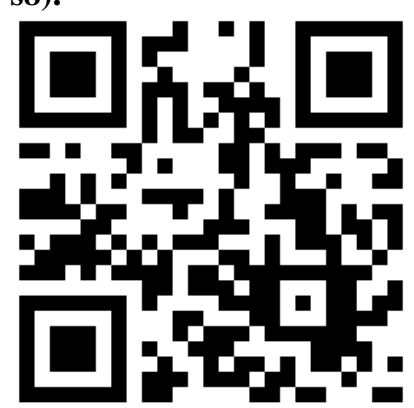

Para visualizar o vídeo você deve utilizar um aplicativo de leitura de $Q R$ code, que pode ser baixado na loja de aplicativos do seu celular procurando por " $Q R$ Scanner" ou acessando o link diretamente do seu computador. 
Figura 19 - Imagens videobroncoscópicas do mesmo animal sadio (M1) (esquerda) e com pneumonia (M2) (direita) induzida pela inoculação de Mannheimia haemolytica, na figura da direita a presença de secreção mucopurulenta amarelo-esverdeada na região da carina - São Paulo, 2014

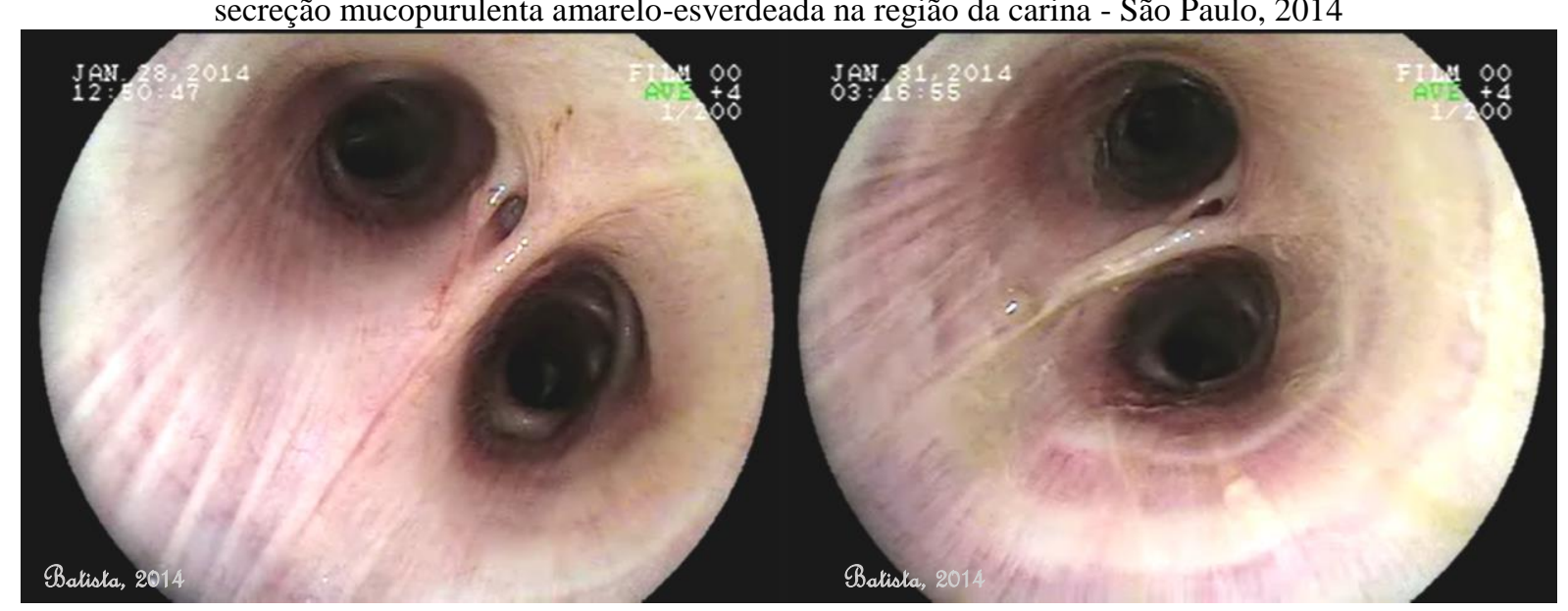

Figura 20 - Imagens videobroncoscópicas obtidas durante o quadro pneumônico por Mannheimia haemolytica: à esquerda presença de secreção mucopurulenta antes da entrada do lobo cranial direito e à direita presença de coloração avermelhada e edema em região de brônquios - São Paulo, 2014

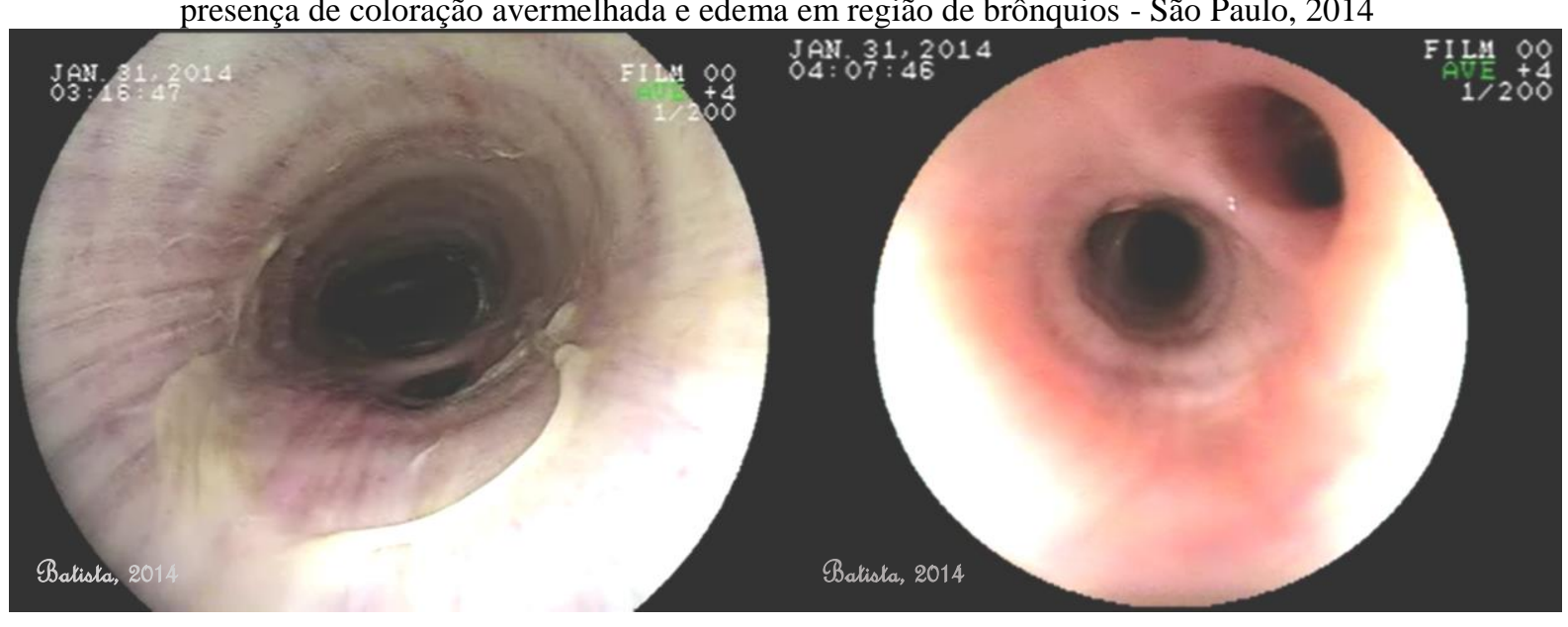

\subsection{AVALIAÇÃO MICROBIOLÓGICA}

No M2 foi isolado $M$. haemolytica no suabe nasal em todos os animais. No lavado traqueobrônquico e no suabe nasal não foi isolado $M$. haemolytica nos M1, M3 e M4, porém outras bactérias foram isoladas nesses momentos (Tabela 2). 
Tabela 2 - Número de amostras com isolamento bacteriano por momento e por agente do lavado traqueobrônquico e do suabe nasal dos bezerros durante os quatro momentos da pesquisa - São Paulo - 2014

\begin{tabular}{cccccccc}
\hline & \multicolumn{3}{c}{ Lavado Traqueobrônquico } \\
\cline { 2 - 8 } Tempo & $\begin{array}{c}\text { Staphylo } \\
\text { coccus }\end{array}$ & $\begin{array}{c}\text { Strepto } \\
\text { coccus }\end{array}$ & $\begin{array}{c}\text { Ausência de } \\
\text { Crescimento }\end{array}$ & $\begin{array}{c}\text { Staphylo } \\
\text { coccus }\end{array}$ & $\begin{array}{c}\text { Strepto } \\
\text { coccus }\end{array}$ & $\begin{array}{c}\text { Mannheimia } \\
\text { haemolytica }\end{array}$ & $\begin{array}{c}\text { Ausência de } \\
\text { Crescimento }\end{array}$ \\
& sp. & sp. & & sp. & sp. & & 2 \\
M1 & 7 & 5 & 2 & 9 & 7 & 0 & 0 \\
M2 & - & - & - & 0 & 0 & 12 & 0 \\
M3 & 8 & 2 & 3 & 9 & 7 & 0 & 0 \\
M4 & 7 & 4 & 2 & 8 & 7 & 0 & 0 \\
\hline
\end{tabular}

\subsection{AVALIAÇÃO DO LAVADO BRONCOALVEOLAR}

Nas tabelas a seguir estão dispostos os resultados referentes à avaliação citológica, à fenotipagem das células mononucleares do lavado broncoalveolar (LBA), à sua avaliação funcional (produção intracelular de ERO, fagocitose bacteriana (M. haemolytica, S. aureus e E. coli)) e à viabilidade celular nos distintos momentos da infecção experimental por $M$. haemolytica.

\subsubsection{Avaliação citológica do LBA}

Os dados da análise citológica broncoalveolar nos distintos momentos da infecção experimental por M. haemolytica estão dispostos na Tabela 3. 
Tabela 3 - Médias e erros padrão dos componentes citológicos do lavado broncoalveolar de bezerros durante os quatro momentos da infecção experimental por Mannheimia haemolytica - São Paulo - 2014

\begin{tabular}{|c|c|c|c|c|c|c|c|c|c|c|}
\hline \multirow[t]{2}{*}{ Tempo } & \multicolumn{2}{|c|}{$\begin{array}{c}\text { Células gigantes } \\
\%\end{array}$} & \multicolumn{2}{|c|}{ Macrófagos \% } & \multicolumn{2}{|c|}{ Neutrófilos \% } & \multicolumn{2}{|c|}{ Linfócitos \% } & \multicolumn{2}{|c|}{ Eosinófilos \% } \\
\hline & G1 & G2 & G1 & G2 & G1 & G2 & G1 & G2 & G1 & G2 \\
\hline M1 & $\begin{array}{c}7,6^{\mathrm{Aa}} \\
( \pm 1,81)\end{array}$ & $\begin{array}{c}7,8^{\mathrm{Aa}} \\
( \pm 2,91)\end{array}$ & $\begin{array}{c}43,4^{\mathrm{Aa}} \\
( \pm 6,60)\end{array}$ & $\begin{array}{l}36,7^{\mathrm{ABa}} \\
( \pm 3,66)\end{array}$ & $\begin{array}{c}9,8^{\mathrm{Aa}} \\
( \pm 3,02)\end{array}$ & $\begin{array}{l}20,3^{\mathrm{ABa}} \\
( \pm 7,66)\end{array}$ & $\begin{array}{c}39,0^{\mathrm{Aa}} \\
( \pm 10,0)\end{array}$ & $\begin{array}{c}34,6^{\mathrm{Aa}} \\
( \pm 6,40)\end{array}$ & $\begin{array}{c}0,0^{\mathrm{Aa}} \\
( \pm 0,00)\end{array}$ & $\begin{array}{c}0,66^{\mathrm{Aa}} \\
( \pm 0,42)\end{array}$ \\
\hline M2 & $\begin{array}{c}15,4^{\text {Aa }} \\
( \pm 4,31)\end{array}$ & $\begin{array}{c}5,6^{\mathrm{Aa}} \\
( \pm 2,94)\end{array}$ & $\begin{array}{c}15,0^{\mathrm{Ba}} \\
( \pm 5,61)\end{array}$ & $\begin{array}{c}18,8^{\mathrm{Ba}} \\
( \pm 3,95)\end{array}$ & $\begin{array}{c}41,8^{\mathrm{Ba}} \\
( \pm 8,93)\end{array}$ & $\begin{array}{c}41,4^{\mathrm{Ba}} \\
( \pm 3,95)\end{array}$ & $\begin{array}{c}27,6^{\mathrm{Aa}} \\
( \pm 7,18)\end{array}$ & $\begin{array}{c}32,8^{\mathrm{Aa}} \\
( \pm 6,57)\end{array}$ & $\begin{array}{c}0,2^{\mathrm{Aa}} \\
( \pm 0,2)\end{array}$ & $\begin{array}{c}0,60^{\mathrm{Aa}} \\
( \pm 0,40)\end{array}$ \\
\hline M3 & $\begin{array}{c}9,0^{\mathrm{Aa}} \\
( \pm 2,25)\end{array}$ & $\begin{array}{c}6,2^{\mathrm{Aa}} \\
( \pm 1,53)\end{array}$ & $\begin{array}{l}43,83^{\mathrm{Aa}} \\
( \pm 6,71)\end{array}$ & $\begin{array}{l}40,6^{\mathrm{ABa}} \\
( \pm 5,92)\end{array}$ & $\begin{array}{c}15,5^{\mathrm{Aa}} \\
( \pm 4,76)\end{array}$ & $\begin{array}{c}13,4^{\mathrm{Aa}} \\
( \pm 7,00)\end{array}$ & $\begin{array}{c}31,5^{\mathrm{Aa}} \\
( \pm 4,54)\end{array}$ & $\begin{array}{c}39,8^{\mathrm{Aa}} \\
( \pm 8,78)\end{array}$ & $\begin{array}{c}0,16^{\mathrm{Aa}} \\
( \pm 0,16)\end{array}$ & $\begin{array}{c}0,0^{\mathrm{Aa}} \\
( \pm 0,00)\end{array}$ \\
\hline M4 & $\begin{array}{c}4,2^{\mathrm{Aa}} \\
( \pm 1,39)\end{array}$ & $\begin{array}{c}6,2^{\mathrm{Aa}} \\
( \pm 2,13)\end{array}$ & $\begin{array}{c}43,4^{\mathrm{Aa}} \\
( \pm 8,02)\end{array}$ & $\begin{array}{c}46,0^{\mathrm{Aa}} \\
( \pm 9,10)\end{array}$ & $\begin{array}{c}12,4^{\mathrm{Aa}} \\
( \pm 3,14)\end{array}$ & $\begin{array}{c}11,2^{\text {Aa }} \\
( \pm 2,47)\end{array}$ & $\begin{array}{c}37,0^{\text {Aa }} \\
( \pm 9,91)\end{array}$ & $\begin{array}{c}38,2^{\text {Aa }} \\
( \pm 10,7)\end{array}$ & $\begin{array}{c}0,4^{\mathrm{Aa}} \\
( \pm 0,24)\end{array}$ & $\begin{array}{c}0,0^{\text {Aa }} \\
( \pm 0,00)\end{array}$ \\
\hline $\mathrm{P}$ & 0,06 & 0,92 & 0,02 & 0,03 & 0,002 & 0,01 & 0,7 & 0,93 & 0,51 & 0,27 \\
\hline
\end{tabular}

M1: Antes da inoculação, M2: Momento das manifestações clínicas, M3: Um dia após o fim do tratamento, M4: Uma semana após o fim do tratamento

G1: norfloxacina associada a flunixina meglumina; G2: somente norfloxacina

Letras Maiúsculas diferentes indicam $\mathrm{P} \leq 0,05$ entre os momentos experimentais.

Letras Minúsculas diferentes indicam $\mathrm{P} \leq 0,05$ entre os grupos.

A análise da porcentagem das populações celulares presentes no lavado broncoalveolar de bezerros foi observado que no M2 a população de macrófagos diminuiu, coincidindo com o aumento da população de neutrófilos.

\subsubsection{Fenotipagem das células mononucleares do LBA}

Nas tabelas 4 e 5 estão dispostos os valores referentes às populações identificadas por citometria de fluxo nas amostras de lavado broncoalveolar dos bezerros durante os quatro momentos experimentais da infecção experimental por $M$. haemolytica. 
Tabela 4 - Medianas e intervalos de confiança das porcentagens de células mononucleares identificadas por citometria de fluxo no lavado broncoalveolar de bezerros durante os quatro momentos da infecção experimental por Mannheimia haemolytica - São Paulo - 2014

\begin{tabular}{ccccc}
\hline Tempo & \multicolumn{2}{c}{ Leucócitos CD45+ } & \multicolumn{2}{c}{ CD45+ + CD14+ } \\
\hline \multirow{2}{*}{ M1 } & G1 & G2 & G1 & G2 \\
& $63,20^{\mathrm{Aa}}$ & $54,55^{\mathrm{Aa}}$ & $89,80^{\mathrm{ABa}}$ & $91,15^{\mathrm{ABa}}$ \\
& $(42,87-83,76)$ & $(37,79-71,27)$ & $(71,84-99,26)$ & $(69,31-99,48)$ \\
M2 & $52,30^{\mathrm{Aa}}$ & $48,60^{\mathrm{Aa}}$ & $33,55^{\mathrm{Aa}}$ & $53,90^{\mathrm{Aa}}$ \\
& $(35,70-68,90)$ & $(37,84-59,79)$ & $(22,17-63,57)$ & $(31,40-64,90)$ \\
\multirow{2}{*}{ M3 } & $67,80^{\mathrm{Aa}}$ & $70,75^{\mathrm{Aa}}$ & $87,60^{\mathrm{ABa}}$ & $77,60^{\mathrm{ABa}}$ \\
& $(62,92-73,94)$ & $(46,97-86,82)$ & $(50,18-101,41)$ & $(54,76-95,54)$ \\
M4 & $67,05^{\mathrm{Aa}}$ & $67,50^{\mathrm{Aa}}$ & $95,65^{\mathrm{Ba}}$ & $98,35^{\mathrm{Ba}}$ \\
& $(52,97-83,66)$ & $(50,08-82,09)$ & $(90,64-99,23)$ & $(89,95-100,98)$ \\
\hline P & 0,51 & 0,31 & 0,0009 & 0,0007 \\
\hline
\end{tabular}

M1: Antes da inoculação, M2: Momento das manifestações clínicas, M3: Um dia após o fim do tratamento, M4: Uma semana após o fim do tratamento

G1: norfloxacina associada a flunixina meglumina; G2: somente norfloxacina

Letras Maiúsculas diferentes indicam $\mathrm{P} \leq 0,05$ entre os momentos experimentais.

Letras Minúsculas diferentes indicam $\mathrm{P} \leq 0,05$ entre os grupos.

Observando as populações de leucócitos $\mathrm{CD} 14^{+}$notou-se menor porcentagem desta população no M2 em relação ao momento M4 em ambos os grupos experimentais.

A quantificação das populações linfocíticas representadas na tabela 5, apresentou aumento da subpopulação $\mathrm{T} C D 8^{+}$e $\mathrm{T} \gamma \delta$ no M2 em relação ao M4 em ambos os grupos, e ainda maior porcentagem de linfócitos $\mathrm{T} \mathrm{CD}^{+}$no M2 que M1 e M3 no G2. 
Tabela 5 - Medianas e intervalos de confiança das porcentagens de células T identificadas por citometria de fluxo no lavado broncoalveolar de bezerros durante os quatro momentos da infecção experimental por Mannheimia haemolytica - São Paulo - 2014

\begin{tabular}{|c|c|c|c|c|c|c|c|c|c|c|}
\hline \multirow[t]{2}{*}{ Tempo } & \multicolumn{2}{|c|}{ Leucócitos CD3+ } & \multicolumn{2}{|c|}{$\begin{array}{c}\mathrm{CD} 3+/ \\
\mathrm{CD} 4+/ \mathrm{CD} 8=\end{array}$} & \multicolumn{2}{|c|}{$\begin{array}{c}\mathrm{CD} 3+/ \\
\mathrm{CD} 4+/ \mathrm{CD} 8+\end{array}$} & \multicolumn{2}{|c|}{$\begin{array}{c}\mathrm{CD} 3+/ \\
\mathrm{CD} 4-/ \mathrm{CD} 8+\end{array}$} & \multicolumn{2}{|c|}{$\begin{array}{c}\mathrm{CD} 3+/ \\
\mathrm{CD} 4-/ \mathrm{CD} 8=\end{array}$} \\
\hline & G1 & G2 & G1 & G2 & G1 & G2 & G1 & G2 & G1 & G2 \\
\hline \multirow{3}{*}{ M1 } & $13,50^{\mathrm{Aa}}$ & $14,60^{\mathrm{Aa}}$ & $1,67^{\mathrm{Aa}}$ & $1,66^{\mathrm{Aa}}$ & $5,40^{\mathrm{ABa}}$ & $5,83^{\mathrm{Aa}}$ & $1,71^{\mathrm{ABa}}$ & $2,13^{\mathrm{Aa}}$ & $2,50^{\mathrm{ABa}}$ & $4,40^{\mathrm{ABa}}$ \\
\hline & $\begin{array}{c}(11,50- \\
15,83)\end{array}$ & $\begin{array}{c}(11,99- \\
16,78)\end{array}$ & $\begin{array}{c}(0,92- \\
2,16)\end{array}$ & $\begin{array}{l}(1,17- \\
2,13)\end{array}$ & $\begin{array}{c}(1,53- \\
8,69)\end{array}$ & $\begin{array}{c}(1,75- \\
8,87)\end{array}$ & $\begin{array}{c}(0,81- \\
3,20)\end{array}$ & $\begin{array}{l}(0,94- \\
3,28)\end{array}$ & $\begin{array}{c}(0,28- \\
9,72)\end{array}$ & $\begin{array}{c}(1,53- \\
9,08)\end{array}$ \\
\hline & $18,80^{\text {Aa }}$ & $19,90^{\mathrm{Aa}}$ & $1,98^{\mathrm{Aa}}$ & $1,58^{\mathrm{Aa}}$ & $3,98^{\mathrm{Aa}}$ & $3,38^{\mathrm{Aa}}$ & $2,75^{\mathrm{Ba}}$ & $2,97^{\mathrm{Ba}}$ & $6,82^{\mathrm{Ba}}$ & $8,10^{\mathrm{Ba}}$ \\
\hline \multirow[t]{2}{*}{ M2 } & $\begin{array}{c}(13,49- \\
23,25)\end{array}$ & $\begin{array}{c}(13,16- \\
24,74)\end{array}$ & $\begin{array}{c}(0,71- \\
3,42)\end{array}$ & $\begin{array}{c}(-0,04- \\
5,16)\end{array}$ & $\begin{array}{c}(0,89- \\
9,28)\end{array}$ & $\begin{array}{l}(0,18- \\
8,22)\end{array}$ & $\begin{array}{c}(0,61- \\
7,20)\end{array}$ & $\begin{array}{c}(2,51- \\
3,84)\end{array}$ & $\begin{array}{l}(2,97- \\
11,63)\end{array}$ & $\begin{array}{l}(3,38- \\
14,65)\end{array}$ \\
\hline & $14,95^{\mathrm{Aa}}$ & $14,85^{\mathrm{Aa}}$ & $2,58^{\mathrm{Aa}}$ & $2,59^{\mathrm{Aa}}$ & $3,79^{\mathrm{Aa}}$ & $3,94^{\mathrm{Aa}}$ & $2,16^{\mathrm{ABa}}$ & $1,61^{\mathrm{Aa}}$ & $6,86^{\mathrm{ABa}}$ & $8,29^{\mathrm{ABa}}$ \\
\hline \multirow[t]{2}{*}{ M3 } & $\begin{array}{l}(6,43- \\
32,93)\end{array}$ & $\begin{array}{c}(10,63- \\
26,40)\end{array}$ & $\begin{array}{c}(-0,67- \\
8,82)\end{array}$ & $\begin{array}{l}(-1,68- \\
10,25)\end{array}$ & $\begin{array}{l}(0,65- \\
9,74)\end{array}$ & $\begin{array}{c}(0,005- \\
8,81)\end{array}$ & $\begin{array}{c}(0,76- \\
4,86)\end{array}$ & $\begin{array}{l}(0,81- \\
2,25)\end{array}$ & $\begin{array}{l}(1,46- \\
13,67)\end{array}$ & $\begin{array}{l}(4,78- \\
11,80)\end{array}$ \\
\hline & $15,30^{\mathrm{Aa}}$ & $13,75^{\text {Аa }}$ & $1,52^{\mathrm{Aa}}$ & $2,27^{\mathrm{Aa}}$ & $6,97^{\mathrm{Ba}}$ & $7,24^{\mathrm{Aa}}$ & $1,60^{\mathrm{Aa}}$ & $1,34^{\mathrm{Aa}}$ & $3,14^{\mathrm{Aa}}$ & $2,60^{\text {Aa }}$ \\
\hline M4 & $\begin{array}{c}(10,69- \\
17,03)\end{array}$ & $\begin{array}{l}(8,80- \\
17,59)\end{array}$ & $\begin{array}{c}(0,85- \\
2,31)\end{array}$ & $\begin{array}{c}(1,31- \\
2,81)\end{array}$ & $\begin{array}{c}(5,16- \\
9,92)\end{array}$ & $\begin{array}{l}(3,83- \\
10,53)\end{array}$ & $\begin{array}{c}(0,91- \\
2,13)\end{array}$ & $\begin{array}{c}(0,73- \\
2,11)\end{array}$ & $\begin{array}{c}(1,62- \\
4,81)\end{array}$ & $\begin{array}{c}(1,24- \\
3,81)\end{array}$ \\
\hline P & 0,47 & 0,66 & 0,21 & 0,77 & 0,57 & 0,49 & 0,005 & 0,0008 & 0,04 & 0,03 \\
\hline
\end{tabular}

M1: Antes da inoculação, M2: Momento das manifestações clínicas, M3: Um dia após o fim do tratamento, M4: Uma semana após o fim do tratamento

G1: norfloxacina associada a flunixina meglumina; G2: somente norfloxacina

Letras Maiúsculas diferentes indicam $\mathrm{P} \leq 0,05$ entre os momentos experimentais.

Letras Minúsculas diferentes indicam $\mathrm{P} \leq 0,05$ entre os grupos.

\subsubsection{Provas funcionais dos fagócitos do LBA}

A seguir estão expressos os valores percentuais dos leucócitos $\mathrm{CD} 14^{+}$do $\mathrm{LBA}$ que produziram ERO e intensidade de fluorescência de ERO basal (Tabela 6), estimulados por $M$. haemolytica (Tabela 7), S. aureus (Tabela 8) e E. coli (Tabela 9) nos distintos momentos do estudo. 
Tabela 6 - Valores medianos e dos intervalos de confiança das células CD14 ${ }^{+}$que produziram espécies reativas de oxigênio basal e intensidade de fluorescência em valores arbitrários no lavado broncoalveolar de bezerros durante os quatro momentos da infecção experimental por Mannheimia haemolytica - São Paulo - 2014

\begin{tabular}{|c|c|c|c|c|}
\hline \multirow[t]{3}{*}{ Tempo } & \multicolumn{4}{|c|}{$\mathrm{CD}^{4} 4^{+}$} \\
\hline & \multicolumn{2}{|c|}{ Produção de ERO (\%) } & \multicolumn{2}{|c|}{ Intensidade de Fluorescência } \\
\hline & G1 & G2 & G1 & G2 \\
\hline \multirow{2}{*}{ M1 } & $40,70^{\mathrm{Aa}}$ & $45,68^{\mathrm{Aa}}$ & $96,93^{\mathrm{Aa}}$ & $93,75^{\mathrm{Aa}}$ \\
\hline & $(28,96-52,44)$ & $(23,32-68,05)$ & $(-1,40-195,27)$ & $(43,02-144,48)$ \\
\hline \multirow{2}{*}{ M2 } & $39,79^{\mathrm{Aa}}$ & $45,00^{\mathrm{Aa}}$ & $54,73^{\mathrm{Aa}}$ & $82,32^{\mathrm{Aa}}$ \\
\hline & $(28,28-51,28)$ & $(34,08-55,92)$ & $(33,61-75,84)$ & $(54,33-110,3)$ \\
\hline \multirow{2}{*}{ M3 } & $38,03^{\mathrm{Aa}}$ & $40,32^{\mathrm{Aa}}$ & $112,60^{\mathrm{Aa}}$ & $187,90^{\mathrm{Aa}}$ \\
\hline & $(30,55-45,52)$ & $(26,68-53,95)$ & $(55,97-169,23)$ & $(53,52-322,28)$ \\
\hline \multirow{2}{*}{ M4 } & $41,28^{\mathrm{Aa}}$ & $46,45^{\mathrm{Aa}}$ & $82,40^{\mathrm{Ab}}$ & $266,07^{\mathrm{Aa}}$ \\
\hline & $(34,52-48,05)$ & $(27,60-65,30)$ & $(-5,70-170,50)$ & $(91,18-440,95)$ \\
\hline P & 0,77 & 0,34 & 0,15 & 0,19 \\
\hline
\end{tabular}

M1: Antes da inoculação, M2: Momento das manifestações clínicas, M3: Um dia após o fim do tratamento, M4: Uma semana após o fim do tratamento

G1: norfloxacina associada a flunixina meglumina; G2: somente norfloxacina

Letras Maiúsculas diferentes indicam $\mathrm{P} \leq 0,05$ entre os momentos experimentais.

Letras Minúsculas diferentes indicam $\mathrm{P} \leq 0,05$ entre os grupos.

Em relação à intensidade de produção de ERO pelas células $\mathrm{CD} 14^{+}$foi observada diferença entre os grupos no momento M4, onde o grupo G1 apresentou menor intensidade de fluorescência do que o grupo $\mathrm{G} 2(\mathrm{P}=0,02)$ (Tabela 6).

Tabela 7 - Valores medianos e dos intervalos de confiança das células CD14 ${ }^{+}$que produziram espécies reativas de oxigênio e intensidade de fluorescência em valores arbitrários no lavado broncoalveolar de bezerros estimulados por Mannheimia haemolytica durante os quatro momentos da infecção experimental por Mannheimia haemolytica - São Paulo - 2014

\begin{tabular}{|c|c|c|c|c|}
\hline \multirow{3}{*}{ Tempo } & \multicolumn{4}{|c|}{ Estimulado por M. haemolytica } \\
\hline & \multicolumn{2}{|c|}{ Produção de ERO (\%) } & \multicolumn{2}{|c|}{ Intensidade de Fluorescência } \\
\hline & G1 & G2 & G1 & G2 \\
\hline \multirow{2}{*}{ M1 } & $42,44^{\text {Aa }}$ & $55,96^{\mathrm{Aa}}$ & $27,27^{\mathrm{Aa}}$ & $30,87^{\mathrm{Ba}}$ \\
\hline & $(19,56-65,31)$ & $(30,51-81,4)$ & $(12,66-41,87)$ & $(17,14-44,59)$ \\
\hline \multirow{2}{*}{ M2 } & $61,04^{\mathrm{Aa}}$ & $71,06^{\mathrm{Aa}}$ & $49,22^{\mathrm{Aa}}$ & $64,67^{\mathrm{ABa}}$ \\
\hline & $(51,82-70,25)$ & $(59,16-82,97)$ & $(28,53-69,90)$ & $(35,86-93,47)$ \\
\hline \multirow{2}{*}{ M3 } & $45,68^{\mathrm{Aa}}$ & $48,51^{\mathrm{Aa}}$ & $130,30^{\mathrm{Aa}}$ & $201,73^{\mathrm{Aa}}$ \\
\hline & $(29,25-62,10)$ & $(33,28-63,73)$ & $(86,47-174,13)$ & $(40,78-362,68)$ \\
\hline \multirow{2}{*}{ M4 } & $45,11^{\mathrm{Aa}}$ & $50,88^{\mathrm{Aa}}$ & $18,23^{\mathrm{Aa}}$ & $20,78^{\mathrm{Ba}}$ \\
\hline & $(24,83-65,39)$ & $(30,83-70,92)$ & $(12,98-23,48)$ & $(14,29-27,28)$ \\
\hline P & 0,15 & 0,12 & 0,15 & 0,0001 \\
\hline
\end{tabular}

M1: Antes da inoculação, M2: Momento das manifestações clínicas, M3: Um dia após o fim do tratamento, M4: Uma semana após o fim do tratamento

G1: norfloxacina associada a flunixina meglumina; G2: somente norfloxacina Letras Maiúsculas diferentes indicam $\mathrm{P} \leq 0,05$ entre os momentos experimentais. Letras Minúsculas diferentes indicam $\mathrm{P} \leq 0,05$ entre os grupos. 
Tabela 8 - Valores medianos e dos intervalos de confiança das células CD14 ${ }^{+}$que produziram espécies reativas de oxigênio e intensidade de fluorescência em valores arbitrários no lavado broncoalveolar de bezerros estimulados por Staphylococcus aureus durante os quatro momentos da infecção experimental por Mannheimia haemolytica - São Paulo - 2014

\begin{tabular}{|c|c|c|c|c|}
\hline \multirow{3}{*}{ Tempo } & \multicolumn{4}{|c|}{ Estimulado por S. aureus } \\
\hline & \multicolumn{2}{|c|}{ Produção de ERO (\%) } & \multicolumn{2}{|c|}{ Intensidade de Fluorescência } \\
\hline & G1 & G2 & G1 & G2 \\
\hline M1 & $\begin{array}{c}32,02^{\mathrm{Aa}} \\
(20,10-43,93)\end{array}$ & $\begin{array}{c}37,73^{\mathrm{Aa}} \\
(16,28-59,17)\end{array}$ & $\begin{array}{c}399,5^{\text {Аa }} \\
(272,25-526,75)\end{array}$ & $\begin{array}{c}323,5^{\mathrm{Aa}} \\
(110,69-536,31)\end{array}$ \\
\hline M2 & $\begin{array}{c}45,26^{\mathrm{Aa}} \\
(11,10-79,42)\end{array}$ & $\begin{array}{c}65,89^{\mathrm{Aa}} \\
(42,2-89,58)\end{array}$ & $\begin{array}{c}110,1^{\mathrm{ABa}} \\
(53,17-167,09)\end{array}$ & $\begin{array}{c}161,28^{\mathrm{ABa}} \\
(28,3-294,16)\end{array}$ \\
\hline M3 & $\begin{array}{c}31,30^{\mathrm{Aa}} \\
(13,40-49,20)\end{array}$ & $\begin{array}{c}37,54^{\mathrm{Aa}} \\
(26,3-48,78)\end{array}$ & $\begin{array}{c}70,60^{\mathrm{Ba}} \\
(54,17-87,02)\end{array}$ & $\begin{array}{c}54,92^{\mathrm{Ba}} \\
(41,39-68,44)\end{array}$ \\
\hline M4 & $\begin{array}{c}23,22^{\mathrm{Aa}} \\
(5,97-40,46)\end{array}$ & $\begin{array}{c}34,69^{\mathrm{Aa}} \\
(10,52-58,87)\end{array}$ & $\begin{array}{c}67,55^{\mathrm{Ba}} \\
(53,95-81,14)\end{array}$ & $\begin{array}{c}60,32^{\mathrm{Ba}} \\
(23,87-96,76)\end{array}$ \\
\hline P & 0,77 & 0,1 & 0,0007 & 0,0001 \\
\hline
\end{tabular}

M1: Antes da inoculação, M2: Momento das manifestações clínicas, M3: Um dia após o fim do tratamento, M4: Uma semana após o fim do tratamento

G1: norfloxacina associada a flunixina meglumina; G2: somente norfloxacina

Letras Maiúsculas diferentes indicam $\mathrm{P} \leq 0,05$ entre os momentos experimentais.

Letras Minúsculas diferentes indicam $\mathrm{P} \leq 0,05$ entre os grupos.

Tabela 9 - Valores medianos e dos intervalos de das células CD14 ${ }^{+}$que produziram espécies reativas de oxigênio e intensidade de fluorescência em valores arbitrários no lavado broncoalveolar de bezerros estimulados por Escherichia coli durante os quatro momentos da infecção experimental por Mannheimia haemolytica - São Paulo - 2014

\begin{tabular}{|c|c|c|c|c|}
\hline \multirow{3}{*}{ Tempo } & \multicolumn{4}{|c|}{ Estimulado por E.coli } \\
\hline & \multicolumn{2}{|c|}{ Produção de ERO (\%) } & \multicolumn{2}{|c|}{ Intensidade de Fluorescência } \\
\hline & G1 & G2 & G1 & G2 \\
\hline M1 & $\begin{array}{c}31,65^{\mathrm{Aa}} \\
(23,21-40.07)\end{array}$ & $\begin{array}{c}37,43^{\mathrm{Aa}} \\
(18,81-56,05)\end{array}$ & $\begin{array}{c}71,77^{\mathrm{Aa}} \\
(19,97-123,56)\end{array}$ & $\begin{array}{c}118,9^{\mathrm{ABa}} \\
(43,62-194,34)\end{array}$ \\
\hline M2 & $\begin{array}{c}41,93^{\mathrm{Aa}} \\
(22,13-61,72)\end{array}$ & $\begin{array}{c}57,43^{\mathrm{Aa}} \\
(40,12-74,75)\end{array}$ & $\begin{array}{c}94,57^{\mathrm{Aa}} \\
(58,48-130,65)\end{array}$ & $\begin{array}{c}159,03^{\text {Aa }} \\
(44,91-273,16)\end{array}$ \\
\hline M3 & $\begin{array}{c}29,57^{\mathrm{Aa}} \\
(12,75-46,39)\end{array}$ & $\begin{array}{c}36,65^{\mathrm{Aa}} \\
(24,5-48,8)\end{array}$ & $\begin{array}{c}60,13^{\mathrm{Ba}} \\
(46,28-73,98)\end{array}$ & $\begin{array}{c}61,33^{\mathrm{Ba}} \\
(48,62-74,04)\end{array}$ \\
\hline M4 & $\begin{array}{c}29,22^{\mathrm{Aa}} \\
(11,28-47,16)\end{array}$ & $\begin{array}{c}41,17^{\mathrm{Aa}} \\
(13,04-69,3)\end{array}$ & $\begin{array}{c}74,73^{\mathrm{Aa}} \\
(53,48-95,98)\end{array}$ & $\begin{array}{c}48,95^{\mathrm{Ba}} \\
(19,59-78,31)\end{array}$ \\
\hline $\mathrm{P}$ & 0,77 & 0,19 & 0,01 & 0,02 \\
\hline
\end{tabular}

M1: Antes da inoculação, M2: Momento das manifestações clínicas, M3: Um dia após o fim do tratamento, M4: Uma semana após o fim do tratamento

G1: norfloxacina associada a flunixina meglumina; G2: somente norfloxacina

Letras Maiúsculas diferentes indicam $\mathrm{P} \leq 0,05$ entre os momentos experimentais.

Letras Minúsculas diferentes indicam $\mathrm{P} \leq 0,05$ entre os grupos.

Quando a produção intracelular de ERO foi estimulada pela presença de bactérias, sua IMF apresentou diferença significativa no G2 quando estimulado por $M$. haemolytica, sendo o M3 maior que M1 e M4. Quando estimulado por S. aureus foi possível observar diferença nas IMF tanto no G1 quanto no G2, o M3 e M4 foram menores que M1 em ambos 
os grupos. Nas amostras sob o estímulo da E. coli foi observada diferença na IMF nos dois grupos ao longo do tempo, em G2 sendo M3 e M4 menores que M2, e em G1 sendo M3 menor em relação aos demais momentos.

Quando a produção de ERO intracelular pelas células $\mathrm{CD} 14^{+}$foi comparada dentro de ambos os grupos ( $\mathrm{P}=0,003$ para $\mathrm{G} 1$ e $\mathrm{P}=0,008$ para $\mathrm{G} 2)$, as células estimuladas por $M$. haemolytica apresentaram maior porcentagem de produção de ERO em relação à produção estimulada por S. aureus e por E. coli (Gráfico 1 e Gráfico 2).

Gráfico 1 - Box Plot da porcentagem de células CD14+ que produziram espécies reativas de oxigênio intracelular dos animais do Grupo 1 entre células do lavado broncoalveolar não estimuladas e estimuladas por bactérias - São Paulo - 2014

\section{Grupo 1}

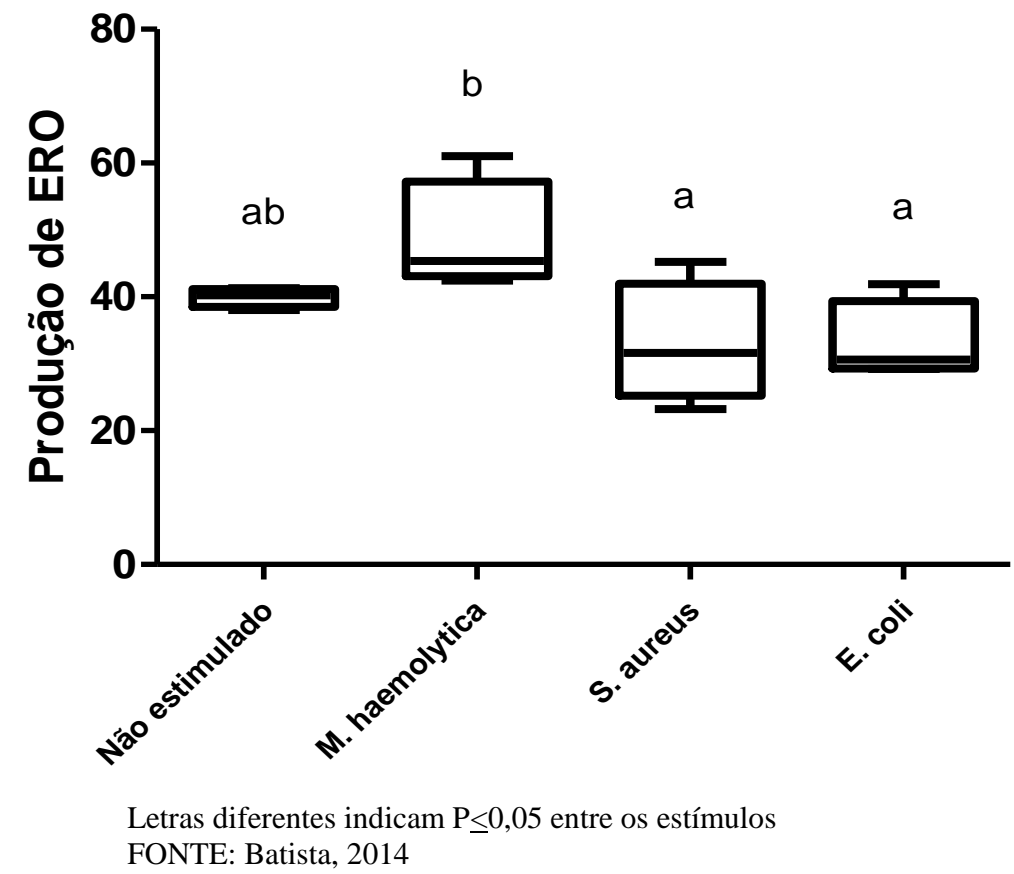


Gráfico 2 - Box Plot da porcentagem de células $\mathrm{CD} 14^{+}$que produziram espécies reativas de oxigênio intracelular dos animais do Grupo 2 entre células do lavado broncoalveolar não estimuladas e estimuladas por bactérias - São Paulo - 2014

\section{Grupo 2}

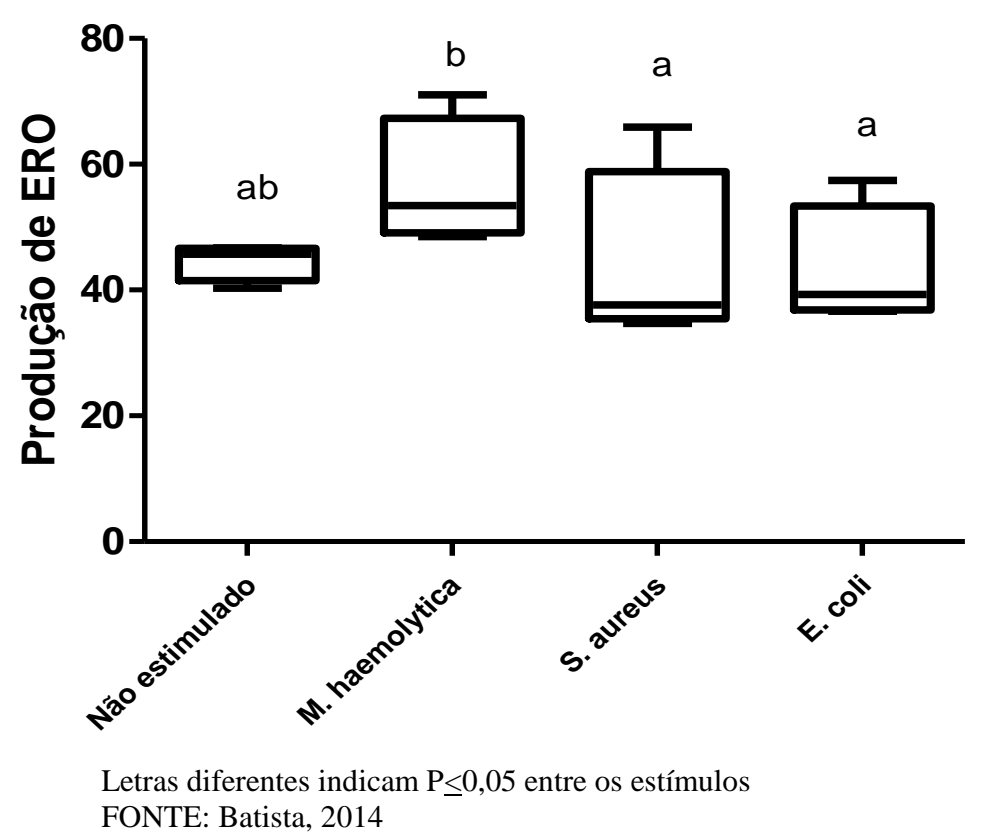

Nas tabelas 10 a 12 estão representadas as medianas e os intervalos de confiança das células $\mathrm{CD}_{14}{ }^{+}$que fagocitaram a $M$. haemolytica, a $S$. aureus e a E. coli, respectivamente.

Tabela 10 - Valores percentuais das medianas e dos intervalos de confiança da fagocitose de Mannheimia haemolytica e intensidade de fluorescência em valores arbitrários no lavado broncoalveolar de bezerros durante os quatro momentos da infecção experimental por Mannheimia haemolytica. São Paulo - 2014

\begin{tabular}{|c|c|c|c|c|}
\hline \multirow{3}{*}{ Tempo } & \multicolumn{4}{|c|}{ M. haemolytica } \\
\hline & \multicolumn{2}{|c|}{ Fagocitose $(\%)$} & \multicolumn{2}{|c|}{ Intensidade de Fluorescência } \\
\hline & G1 & G2 & G1 & G2 \\
\hline M1 & $\begin{array}{c}51,76^{\mathrm{ABa}} \\
(33,37-70,15)\end{array}$ & $\begin{array}{c}66,98^{\mathrm{ABa}} \\
(61,24-72,71)\end{array}$ & $\begin{array}{c}27,27^{\mathrm{Ba}} \\
(12,66-41,87)\end{array}$ & $\begin{array}{c}30,87^{\mathrm{Ba}} \\
(17,14-44,59)\end{array}$ \\
\hline M2 & $\begin{array}{c}33,12^{\mathrm{Ba}} \\
(15,39-50,85)\end{array}$ & $\begin{array}{c}43,48^{\mathrm{Ba}} \\
(22,14-64,81)\end{array}$ & $\begin{array}{c}49,22^{\mathrm{ABa}} \\
(28,53-69,90)\end{array}$ & $\begin{array}{c}64,67^{\mathrm{ABa}} \\
(35,86-93,47)\end{array}$ \\
\hline M3 & $\begin{array}{c}80,83^{\text {Aa }} \\
(62,50-99,15)\end{array}$ & $\begin{array}{c}84,15^{\mathrm{Aa}} \\
(54,51-100,72)\end{array}$ & $\begin{array}{c}130,30^{\text {Aa }} \\
(86,47-174,13)\end{array}$ & $\begin{array}{c}201,73^{\mathrm{Aa}} \\
(40,78-362,68)\end{array}$ \\
\hline M4 & $\begin{array}{c}84,57^{\mathrm{Aa}} \\
(74,40-94,73)\end{array}$ & $\begin{array}{c}83,90^{\mathrm{Aa}} \\
(77,01-90,78)\end{array}$ & $\begin{array}{c}18,23^{\mathrm{Ba}} \\
(12,98-23,48)\end{array}$ & $\begin{array}{c}20,78^{\mathrm{Ba}} \\
(14,29-27,28)\end{array}$ \\
\hline $\mathrm{P}$ & 0,002 & 0,013 & 0,0006 & 0,0001 \\
\hline
\end{tabular}

M1: Antes da inoculação, M2: Momento das manifestações clínicas, M3: Um dia após o fim do tratamento, M4: Uma semana após o fim do tratamento

G1: norfloxacina associada a flunixina meglumina; G2: somente norfloxacina

Letras Maiúsculas diferentes indicam $\mathrm{P} \leq 0,05$ entre os momentos experimentais.

Letras Minúsculas diferentes indicam $\mathrm{P} \leq 0,05$ entre os grupos. 
Tabela 11 - Valores percentuais das medianas e dos intervalos de confiança da fagocitose de Staphylococcus aureus e intensidade de fluorescência em valores arbitrários no LBA de bezerros durante os quatro momentos da infecção experimental por Mannheimia haemolytica - São Paulo - 2014

\begin{tabular}{ccccc}
\hline \multirow{2}{*}{ Tempo } & \multicolumn{4}{c}{ S. aureus } \\
\cline { 2 - 5 } & \multicolumn{2}{c}{ Fagocitose (\%) } & \multicolumn{3}{c}{ Intensidade de Fluorescência } \\
\cline { 2 - 5 } M1 & $47,80^{\mathrm{Ba}}$ & $46,21^{\mathrm{ABa}}$ & $\mathbf{G 1}$ & G2 \\
& $(13,95-81,63)$ & $(8,56-83,85)$ & $(3,05-13,95)$ & $(3,03-13,75)$ \\
\multirow{2}{*}{ M2 } & $56,24^{\mathrm{ABa}}$ & $42,73^{\mathrm{Ba}}$ & $11,67^{\mathrm{Aa}}$ & $7,94^{\mathrm{Aa}}$ \\
& $(33,21-79,27)$ & $(27,00-58,47)$ & $(5,45-17,89)$ & $(5,95-9,93)$ \\
\multirow{2}{*}{ M3 } & $56,39^{\mathrm{ABa}}$ & $54,03^{\mathrm{ABa}}$ & $16,55^{\mathrm{Aa}}$ & $14,35^{\mathrm{ABa}}$ \\
& $(35,87-76,91)$ & $(37,11-70,94)$ & $(9,08-24,03)$ & $(9,47-19,23)$ \\
M4 & $90,72^{\mathrm{Aa}}$ & $89,12^{\mathrm{Aa}}$ & $21,22^{\mathrm{Aa}}$ & $20,15^{\mathrm{Aa}}$ \\
& $(84,50-96,93)$ & $(79,34-98,89)$ & $(9,62-32,82)$ & $(10,70-29,60)$ \\
\hline & 0,03 & 0,04 & 0,09 & 0,015 \\
\hline
\end{tabular}

M1: Antes da inoculação, M2: Momento das manifestações clínicas, M3: Um dia após o fim do tratamento, M4: Uma semana após o fim do tratamento

G1: norfloxacina associada a flunixina meglumina; G2: somente norfloxacina

Letras Maiúsculas diferentes indicam $\mathrm{P} \leq 0,05$ entre os momentos experimentais.

Letras Minúsculas diferentes indicam $\mathrm{P} \leq 0,05$ entre os grupos.

Tabela 12 - Valores percentuais das medianas e dos intervalos de confiança da fagocitose de Escherichia coli e intensidade de fluorescência em valores arbitrários no LBA de bezerros durante os quatro momentos da infecção experimental por Mannheimia haemolytica - São Paulo - 2014

\begin{tabular}{|c|c|c|c|c|}
\hline \multirow{3}{*}{ Tempo } & \multicolumn{4}{|c|}{ E.coli } \\
\hline & \multicolumn{2}{|c|}{ Fagocitose (\%) } & \multicolumn{2}{|c|}{ Intensidade de Fluorescência } \\
\hline & G1 & G2 & G1 & G2 \\
\hline M1 & $\begin{array}{c}39,77^{\mathrm{Aa}} \\
(18,36-61,18)\end{array}$ & $\begin{array}{c}49,67^{\mathrm{Aa}} \\
(30,20-69,15)\end{array}$ & $\begin{array}{c}6,81^{\mathrm{Aa}} \\
(3,06-10,56)\end{array}$ & $\begin{array}{c}7,05^{\mathrm{Aa}} \\
(4,24-9,86)\end{array}$ \\
\hline M2 & $\begin{array}{c}53,62^{\mathrm{ABa}} \\
(33,11-74,13)\end{array}$ & $\begin{array}{c}47,90^{\mathrm{Aa}} \\
(33,08-62,72)\end{array}$ & $\begin{array}{c}12,16^{\mathrm{ABa}} \\
(6,69-17,63)\end{array}$ & $\begin{array}{c}9,79^{\text {Aa }} \\
(6,51-13,06)\end{array}$ \\
\hline M3 & $\begin{array}{c}58,69^{\mathrm{ABa}} \\
(35,84-81,53)\end{array}$ & $\begin{array}{c}50,97^{\mathrm{Aa}} \\
(34,76-67,18)\end{array}$ & $\begin{array}{c}26,93^{\mathrm{Ba}} \\
(8,74-45,10)\end{array}$ & $\begin{array}{c}14,03^{\mathrm{Aa}} \\
(8,13-19,92)\end{array}$ \\
\hline M4 & $\begin{array}{c}88,13^{\mathrm{Ba}} \\
(80,05-96,20)\end{array}$ & $\begin{array}{c}84,26^{\mathrm{Aa}} \\
(73,10-95,42)\end{array}$ & $\begin{array}{c}26,75^{\mathrm{Ba}} \\
(13,54-39,95)\end{array}$ & $\begin{array}{c}16,28^{\mathrm{Aa}} \\
(8,70-23,84)\end{array}$ \\
\hline $\mathbf{P}$ & 0,005 & 0,07 & 0,007 & 0,12 \\
\hline
\end{tabular}

M1: Antes da inoculação, M2: Momento das manifestações clínicas, M3: Um dia após o fim do tratamento, M4: Uma semana após o fim do tratamento

G1: norfloxacina associada a flunixina meglumina; G2: somente norfloxacina

Letras Maiúsculas diferentes indicam $\mathrm{P} \leq 0,05$ entre os momentos experimentais.

Letras Minúsculas diferentes indicam $\mathrm{P} \leq 0,05$ entre os grupos.

A avaliação da prova de fagocitose com $M$. haemolytica apontou diferença entre os momentos nos dois grupos. A porcentagem de fagocitose de $M$. haemolytica por células $\mathrm{CD}_{14}{ }^{+}$no $\mathrm{M} 2$ foi menor em relação às porcentagens em M3 e M4 (Figura 21). A IMF da fagocitose deste agente nos dois grupos foi maior no M3 que M1 e M4.

No ensaio realizado para as provas de fagocitose com $S$. aureus, foi observada maior porcentagem de fagocitose de células $\mathrm{CD}_{1}{ }^{+}$no $\mathrm{M} 4$ em relação à $\mathrm{M} 1$ e M2 nos G1 e G2 
respectivamente. Quando observados os valores referentes à IMF de fagocitose de S. aureus por células CD14+ observou-se maior IMF no M4 que M1 e M2, apenas no G2.

Quanto à porcentagem de células $\mathrm{CD}_{1} 4^{+}$que fagocitaram E. coli, observou-se maior fagocitose no M4 que M1, apenas em G1 e maior IMF de fagocitose de E. coli por células $\mathrm{CD}_{14}^{+}$em M3 e M4 que M1, também no G1.

As porcentagens de fagocitose foram comparadas entre os diferentes patógenos utilizados, porém não apresentaram diferença em nenhum dos dois grupos $(\mathrm{P}=0,93$ e $\mathrm{P}=0,25$, $\mathrm{G} 1$ e G2 respectivamente). Assim como as suas IMF, que não apresentaram diferença ( $\mathrm{P}=0,15$ e $\mathrm{P}=0,15, \mathrm{G} 1$ e $\mathrm{G} 2$ respectivamente).

Figura 21 - Representação gráfica da evolução da fagocitose de Mannheimia haemolytica do mesmo animal durante os quatro momentos da infecção experimental por Mannheimia haemolytica - São Paulo - 2014

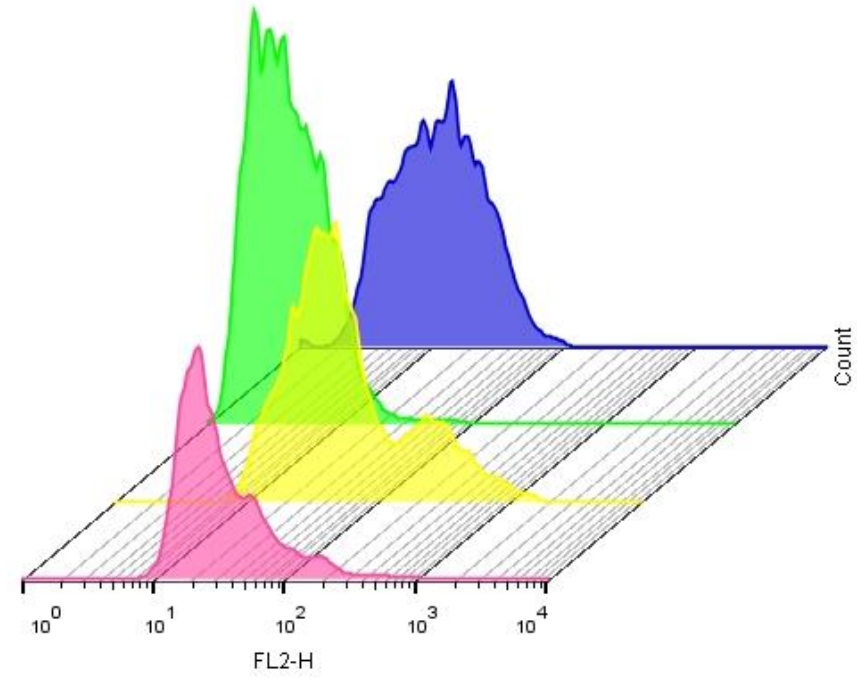

\begin{tabular}{|l|l|l|r|}
\hline & Sample Hame & Subset Hame & Count \\
\hline & G AIP.110 & CD14+ & 1514 \\
\hline & G AIP.025 & CD $14+$ & 2868 \\
\hline & G AIP. 124 & CD $14+$ & 3448 \\
\hline$\square$ & G AIP.038 & CD14+ & 2731 \\
\hline
\end{tabular}

FONTE: Batista, 2014

O gráfico azul representa M1: Antes da inoculação, o gráfico verde M2: Momento das manifestações clínicas, o gráfico amarelo M3: Um dia após o fim do tratamento e o gráfico rosa M4: Uma semana após o fim do tratamento.

\subsubsection{Viabilidade das células mononucleares do LBA}

Na tabela 13 estão representados os valores das médias e dos erros padrão das células CD14 ${ }^{+}$do LBA em apoptose (Anexina $\mathrm{V}^{+} / \mathrm{PI}^{-}$), necrose (Anexina $\mathrm{V}^{-} / \mathrm{PI}^{+}$), apoptose e/ou necrose (Anexina $\mathrm{V}^{+} / \mathrm{PI}^{+}$) e a viabilidade (Anexina $\mathrm{V}^{-} / \mathrm{PI}^{-}$) das mesmas, ao longo do estudo. 
Tabela 13 - Valores médios e dos erros padrão das células $\mathrm{CD}_{14}{ }^{+}$em apoptose, necrose, apoptose e/ou necrose e viabilidade das mesmas no lavado broncoalveolar de bezerros durante os quatro momentos da infecção experimental por Mannheimia haemolytica - São Paulo - 2014

\begin{tabular}{|c|c|c|c|c|c|c|c|c|}
\hline Tempo & \multicolumn{2}{|c|}{ Anexina $\mathrm{V}^{+} / \mathrm{PI}^{-}(\%)$} & \multicolumn{2}{|c|}{ Anexina $\mathrm{V}^{-} / \mathrm{PI}^{+}(\%)$} & \multicolumn{2}{|c|}{ Anexina $\mathrm{V}^{+} / \mathrm{PI}^{+}(\%)$} & \multicolumn{2}{|c|}{ Anexina $\mathrm{V}^{-} / \mathrm{PI}(\%)$} \\
\hline & G1 & G2 & G1 & G2 & G1 & G2 & G1 & G2 \\
\hline M1 & $\begin{array}{c}3,64^{\mathrm{ABa}} \\
( \pm 1,696)\end{array}$ & $\begin{array}{c}4,74^{\mathrm{ABa}} \\
( \pm 1,831)\end{array}$ & $\begin{array}{c}27,15^{\mathrm{Ba}} \\
( \pm 6,869)\end{array}$ & $\begin{array}{l}18,71^{\mathrm{BCa}} \\
( \pm 3,933)\end{array}$ & $\begin{array}{c}1,37^{\mathrm{Ba}} \\
( \pm 0,207)\end{array}$ & $\begin{array}{c}1,62^{\text {Аa }} \\
( \pm 0,431)\end{array}$ & $\begin{array}{l}67,85^{\mathrm{ABa}} \\
( \pm 5,445)\end{array}$ & $\begin{array}{l}74,98^{\mathrm{ABa}} \\
( \pm 4,492)\end{array}$ \\
\hline M2 & $\begin{array}{c}2,13^{\mathrm{Ba}} \\
( \pm 0,647)\end{array}$ & $\begin{array}{c}1,12^{\mathrm{Ba}} \\
( \pm 0,963)\end{array}$ & $\begin{array}{c}70,35^{\text {Aa }} \\
( \pm 6,306)\end{array}$ & $\begin{array}{r}78,55^{\text {Aa }} \\
( \pm 4,969)\end{array}$ & $\begin{array}{c}10,14^{\mathrm{Aa}} \\
( \pm 2,440)\end{array}$ & $\begin{array}{c}6,29^{\mathrm{Aa}} \\
( \pm 2,104)\end{array}$ & $\begin{array}{r}17,38^{\mathrm{Ca}} \\
( \pm 3,458)\end{array}$ & $\begin{array}{r}14,02^{\mathrm{Ca}} \\
( \pm 3,426)\end{array}$ \\
\hline M3 & $\begin{array}{c}3,29^{\mathrm{ABa}} \\
( \pm 0,913)\end{array}$ & $\begin{array}{c}5,93^{\mathrm{Aa}} \\
( \pm 2,594)\end{array}$ & $\begin{array}{c}28,55^{\mathrm{Ba}} \\
( \pm 6,176)\end{array}$ & $\begin{array}{c}27,00^{\mathrm{Ba}} \\
( \pm 5,291)\end{array}$ & $\begin{array}{c}5,83^{\mathrm{ABa}} \\
( \pm 4,077)\end{array}$ & $\begin{array}{c}5,11^{\mathrm{Aa}} \\
( \pm 2,080)\end{array}$ & $\begin{array}{c}62,33^{\mathrm{Ba}} \\
( \pm 7,454)\end{array}$ & $\begin{array}{c}61,97^{\mathrm{Ba}} \\
( \pm 4,753)\end{array}$ \\
\hline M4 & $\begin{array}{c}6,37^{\mathrm{Ab}} \\
( \pm 0,562)\end{array}$ & $\begin{array}{c}8,23^{\mathrm{Aa}} \\
( \pm 0,839)\end{array}$ & $\begin{array}{c}8,27^{\mathrm{Ba}} \\
( \pm 1,482)\end{array}$ & $\begin{array}{r}10,05^{\mathrm{Ca}} \\
( \pm 1,389)\end{array}$ & $\begin{array}{c}1,51^{\mathrm{Ba}} \\
( \pm 0,298)\end{array}$ & $\begin{array}{c}2,45^{\text {Аa }} \\
( \pm 0,589)\end{array}$ & $\begin{array}{l}83,82^{\text {Aa }} \\
( \pm 1,402)\end{array}$ & $\begin{array}{r}79,28^{\text {Aa }} \\
( \pm 1,653)\end{array}$ \\
\hline $\mathrm{P}$ & 0,011 & 0,004 & $<0,0001$ & $<0,0001$ & 0,044 & 0,205 & $<0,0001$ & $<0,0001$ \\
\hline
\end{tabular}

M1: Antes da inoculação, M2: Momento das manifestações clínicas, M3: Um dia após o fim do tratamento, M4: Uma semana após o fim do tratamento

G1: norfloxacina associada a flunixina meglumina; G2: somente norfloxacina

Letras Maiúsculas diferentes indicam $\mathrm{P} \leq 0,05$ entre os momentos experimentais.

Letras Minúsculas diferentes indicam $\mathrm{P} \leq 0,05$ entre os grupos.

Anexina $\mathrm{V}^{+} / \mathrm{PI}^{*}$ : Células em apoptose; Anexina $\mathrm{V}^{-} / \mathrm{PI}^{+}$: Células em necrose; Anexina $\mathrm{V}^{+} / \mathrm{PI}^{+}$: Células em apoptose e/ou necrose; Anexina V־/PI": Células viáveis

Quando analisados os dados de viabilidade celular pôde-se observar que no M2 houve redução da porcentagem de células $\mathrm{CD} 14^{+}$em apoptose em relação à M4 em ambos os grupos e à M3 no G2. A porcentagem de células $\mathrm{CD}_{1} 4^{+}$em necrose foi maior em M2 que em todos os demais momentos no G1 e que M3 e M4 no G2. A porcentagem de células CD14 em apoptose tardia ou necrose secundária foi maior no M2 que M4 e M1, apenas no G1. As porcentagens de células $\mathrm{CD}_{14}^{+}$viáveis foram maiores no M4 que M2 e M3 e, maior no M3 que M2, em ambos os grupos.

\subsection{AVALIAÇÃO DO SANGUE}

Nas tabelas a seguir estão dispostos os resultados referentes ao hemograma, à fenotipagem das células sanguíneas, à sua avaliação funcional relativas a viabilidade, produção intracelular de ERO, fagocitose bacteriana (M. haemolytica, S. aureus e E. coli), nos distintos momentos da pesquisa. 


\subsubsection{Leucograma}

Utilizou-se os valores dos leucogramas para avaliar a evolução do quadro clínico. $\mathrm{Na}$ Tabela 14 seguem os valores médios e erros padrão do leucograma durante os quatro momentos da infecção experimental por M. haemolytica.

Tabela 14 - Valores médios absolutos e erros padrão do leucograma de amostras de sangue de bezerros durante os quatro momentos da infecção experimental por Mannheimia haemolytica - São Paulo - 2014

\begin{tabular}{|c|c|c|c|c|c|c|c|c|c|c|}
\hline \multirow[t]{2}{*}{ Tempo } & \multicolumn{2}{|c|}{$\begin{array}{l}\text { Leucócitos x } 10^{3} \\
\qquad / \mathrm{uL}\end{array}$} & \multicolumn{2}{|c|}{$\begin{array}{c}\text { Neutrófilos x } 10^{3} \\
/ \mu L\end{array}$} & \multicolumn{2}{|c|}{$\begin{array}{l}\text { Linfócitos x } 10^{3} \\
\qquad / \mu \mathrm{L}\end{array}$} & \multicolumn{2}{|c|}{$\begin{array}{l}\text { Monócitos x } 10^{3} \\
/ \mu L\end{array}$} & \multicolumn{2}{|c|}{$\begin{array}{c}\text { Eosinófillos x } 10^{3} \\
\qquad / \mathrm{LL}\end{array}$} \\
\hline & G1 & G2 & G1 & G2 & G1 & G2 & G1 & G2 & G1 & G2 \\
\hline N & $\begin{array}{l}7,40^{\mathrm{Ba}} \\
( \pm 1,0)\end{array}$ & $\begin{array}{c}7,70^{\mathrm{ABa}} \\
( \pm 1,0)\end{array}$ & $\begin{array}{c}1,88^{\mathrm{Ba}} \\
( \pm 0,54)\end{array}$ & $\begin{array}{l}1,79^{\mathrm{Aa}} \\
( \pm 0,39)\end{array}$ & $\begin{array}{l}5,14^{\mathrm{Aa}} \\
( \pm 0,74)\end{array}$ & $\begin{array}{l}5,40^{\mathrm{Aa}} \\
( \pm 0,46)\end{array}$ & $( \pm 0,00)$ & & $\begin{array}{c}0,37^{\mathrm{Aa}} \\
( \pm 0,18)\end{array}$ & $\begin{array}{c}0,40^{\mathrm{Aa}} \\
( \pm 0,22)\end{array}$ \\
\hline & $\begin{array}{l}10,36 \\
( \pm 1,18\end{array}$ & $\begin{array}{l}9,10^{\mathrm{Aa}} \\
( \pm 0,66)\end{array}$ & $\begin{array}{l}4,78^{\text {Aa }} \\
( \pm 0,86)\end{array}$ & $\begin{array}{l}3,30^{\mathrm{Aa}} \\
( \pm 0,89)\end{array}$ & $\begin{array}{l}5,52^{\mathrm{Aa}} \\
( \pm 0,62)\end{array}$ & $\begin{array}{l}5,53^{\mathrm{Aa}} \\
( \pm 0,62)\end{array}$ & & & $\begin{array}{c}0,09^{\mathrm{Aa}} \\
( \pm 0,04)\end{array}$ & $\begin{array}{l}0,17^{\text {Aa }} \\
( \pm 0,04)\end{array}$ \\
\hline N & $\begin{array}{l}9,13^{\mathrm{ABa}} \\
( \pm 0,69)\end{array}$ & $\begin{array}{l}8,66^{\mathrm{ABa}} \\
( \pm 0,97)\end{array}$ & $\begin{array}{c}3,17^{\mathrm{ABa}} \\
( \pm 0,4)\end{array}$ & $\begin{array}{l}3,25^{\mathrm{Aa}} \\
( \pm 0,75)\end{array}$ & $\begin{array}{c}5,89^{\mathrm{Aa}} \\
( \pm 0,80)\end{array}$ & $\begin{array}{l}5,31^{\mathrm{Aa}} \\
( \pm 0,46)\end{array}$ & $\begin{array}{l}0,00^{\mathrm{Aa}} \\
( \pm 0,00)\end{array}$ & $\begin{array}{c}0,00^{\mathrm{Aa}} \\
( \pm 0,00)\end{array}$ & $\begin{array}{l}0,06^{\mathrm{Aa}} \\
( \pm 0,05)\end{array}$ & $\begin{array}{c}0,11^{\mathrm{Aa}} \\
( \pm 0,06)\end{array}$ \\
\hline M4 & $\begin{array}{l}7,60^{\mathrm{Ba}} \\
( \pm 0,6)\end{array}$ & $\begin{array}{l}7,43^{\mathrm{Ba}} \\
( \pm 0,7)\end{array}$ & $\begin{array}{c}1,67^{\mathrm{Ba}} \\
( \pm 0,33)\end{array}$ & $\begin{array}{l}1,91^{\mathrm{Aa}} \\
( \pm 0,25)\end{array}$ & $\begin{array}{l}5,63^{\mathrm{Aa}} \\
( \pm 0,60)\end{array}$ & $\begin{array}{c}5,43^{\mathrm{Aa}} \\
( \pm 0,54)\end{array}$ & $\begin{array}{l}0,00^{\mathrm{Aa}} \\
( \pm 0,00)\end{array}$ & $\begin{array}{l}0,00^{\mathrm{Aa}} \\
( \pm 0,00)\end{array}$ & $\begin{array}{l}0,24^{\mathrm{Aa}} \\
( \pm 0,14)\end{array}$ & $\begin{array}{l}0,09^{\mathrm{Aa}} \\
( \pm 0,02)\end{array}$ \\
\hline $\mathrm{P}$ & 0,009 & 0,04 & 0,008 & 0,13 & 0,6 & 0,85 & 0,42 & 0,44 & 0,21 & 0,31 \\
\hline
\end{tabular}

M1: Antes da inoculação, M2: Momento das manifestações clínicas, M3: Um dia após o fim do tratamento, M4: Uma semana após o fim do tratamento

G1: norfloxacina associada a flunixina meglumina; G2: somente norfloxacina

Letras Maiúsculas diferentes indicam $\mathrm{P} \leq 0,05$ entre os momentos experimentais.

Letras Minúsculas diferentes indicam $\mathrm{P} \leq 0,05$ entre os grupos.

$\mathrm{Na}$ série branca encontrou-se aumento dos valores de leucócitos totais em M2 em relação ao M4, para os dois grupos e em relação ao M1 do G1. Esse aumento de leucócitos totais em M2 foi devido ao aumento de neutrófilos no G1.

\subsubsection{Fenotipagem das células do sangue}

Nas tabelas 15 a 18 estão dispostos os valores referentes à quantificação das populações leucocitárias nas amostras de sangue dos bezerros, durante os quatro momentos da infecção experimental por M. haemolytica. 
Tabela 15 - Medianas e intervalos de confiança das porcentagens de leucócitos mononucleares identificadas por citometria de fluxo no sangue de bezerros durante os quatro momentos da infecção experimental por Mannheimia haemolytica - São Paulo - 2014

\begin{tabular}{|c|c|c|c|c|c|c|c|c|}
\hline \multirow[t]{2}{*}{ Tempo } & \multicolumn{2}{|c|}{ Total de Mononucleares } & \multicolumn{2}{|c|}{ Total de Monócitos } & \multicolumn{2}{|c|}{ Monócitos CD45+ } & \multicolumn{2}{|c|}{$\mathrm{CD} 45+/ \mathrm{CD} 14+$} \\
\hline & G1 & G2 & G1 & G2 & G1 & G2 & G1 & G2 \\
\hline M1 & $\begin{array}{c}59,15^{\text {Aa }} \\
(49,40-64,54)\end{array}$ & $\begin{array}{c}55,05^{\mathrm{Aa}} \\
(53,12-59,88)\end{array}$ & $\begin{array}{c}1,78^{\mathrm{Aa}} \\
(0,87-4,01)\end{array}$ & $\begin{array}{c}2,09^{\mathrm{Aa}} \\
(1,40-2,63)\end{array}$ & $\begin{array}{c}62,05^{\mathrm{Aa}} \\
(41,69-87,84)\end{array}$ & $\begin{array}{c}67,55^{\mathrm{Aa}} \\
(44,49-81,47)\end{array}$ & $\begin{array}{c}79,00^{\mathrm{Aa}} \\
(67,53-91,90)\end{array}$ & $\begin{array}{c}83,85^{\text {Aa }} \\
(69,14-93,82)\end{array}$ \\
\hline M2 & $\begin{array}{c}55,60^{\text {Аа }} \\
(40,70-65,70)\end{array}$ & $\begin{array}{c}44,70^{\mathrm{Aa}} \\
(32,37-60,66)\end{array}$ & $\begin{array}{c}2,38^{\text {Аa }} \\
(1,65-3,97)\end{array}$ & $\begin{array}{c}1,52^{\mathrm{Aa}} \\
(0,90-2,75)\end{array}$ & $\begin{array}{c}78,45^{\text {Аа }} \\
(54,27-94,49)\end{array}$ & $\begin{array}{c}75,55^{\text {Аа }} \\
(50,70-91,39)\end{array}$ & $\begin{array}{c}68,65^{\mathrm{Aa}} \\
(53,47-93,99)\end{array}$ & $\begin{array}{c}63,20^{\mathrm{Aa}} \\
(47,06-88,87)\end{array}$ \\
\hline M3 & $\begin{array}{c}48,30^{\mathrm{Aa}} \\
(40,36-60,14)\end{array}$ & $\begin{array}{c}51,25^{\mathrm{Aa}} \\
(39,80-66,86)\end{array}$ & $\begin{array}{c}2,51^{\mathrm{Aa}} \\
(1,75-3,64)\end{array}$ & $\begin{array}{c}3,20^{\mathrm{Aa}} \\
(2,00-4,37)\end{array}$ & $\begin{array}{c}60,00^{\mathrm{Aa}} \\
(45,14-80,19)\end{array}$ & $\begin{array}{c}61,25^{\mathrm{Aa}} \\
(42,84-78,39)\end{array}$ & $\begin{array}{c}72,40^{\mathrm{Aa}} \\
(42,57-90,79)\end{array}$ & $\begin{array}{c}68,35^{\text {Aa }} \\
(47,44-80,49)\end{array}$ \\
\hline M4 & $\begin{array}{c}55,20^{\mathrm{Aa}} \\
(43,59-66,04)\end{array}$ & $\begin{array}{c}52,50^{\text {Аа }} \\
(45,34-61,85)\end{array}$ & $\begin{array}{c}1,66^{\mathrm{Aa}} \\
(1,22-1,89)\end{array}$ & $\begin{array}{c}1,91^{\text {Аa }} \\
(1,17-2,66)\end{array}$ & $\begin{array}{c}62,15^{\mathrm{Aa}} \\
(55,20-77,10)\end{array}$ & $\begin{array}{c}72,65^{\text {Аа }} \\
(57,25-90,65)\end{array}$ & $\begin{array}{c}69,45^{\text {Аа }} \\
(56,41-83,82)\end{array}$ & $\begin{array}{c}60,05^{\mathrm{Aa}} \\
(46,45-77,15)\end{array}$ \\
\hline $\mathrm{P}$ & 0,66 & 0,28 & 0,10 & 0,06 & 0,51 & 0,51 & 0,60 & 0,57 \\
\hline
\end{tabular}

M1: Antes da inoculação, M2: Momento das manifestações clínicas, M3: Um dia após o fim do tratamento, M4: Uma semana após o fim do tratamento

G1: norfloxacina associada a flunixina meglumina; G2: somente norfloxacina

Letras Maiúsculas diferentes indicam $\mathrm{P} \leq 0,05$ entre os momentos experimentais.

Letras Minúsculas diferentes indicam $\mathrm{P} \leq 0,05$ entre os grupos.

Tabela 16 - Médias e erros padrão das porcentagens populacionais de granulócitos identificadas por citometria de fluxo no sangue de bezerros durante os quatro momentos da infecção experimental por Mannheimia haemolytica - São Paulo - 2014

\begin{tabular}{ccccccc}
\hline \multirow{2}{*}{ Tempo } & \multicolumn{2}{c}{$\begin{array}{c}\text { População total de } \\
\text { Granulócitos }\end{array}$} & $\begin{array}{c}\text { População de Granulócitos } \\
\text { CD45+ }\end{array}$ & \multicolumn{2}{c}{$\begin{array}{c}\text { População de CD45+ que } \\
\text { são CH138+ }\end{array}$} \\
& G1 & G2 & G1 & G2 & G1 & G2 \\
M1 & $22,10^{\mathrm{Aa}}$ & $23,20^{\mathrm{Aa}}$ & $86,85^{\mathrm{Aa}}$ & $73,95^{\mathrm{Aa}}$ & $82,90^{\mathrm{Aa}}$ & $93,90^{\mathrm{Aa}}$ \\
& $(18,74-24,96)$ & $(19,58-29,35)$ & $(60,38-100,19)$ & $(60,37-93,33)$ & $(55,98-101,49)$ & $(71,83-102,90)$ \\
M2 & $25,40^{\mathrm{Aa}}$ & $27,50^{\mathrm{Aa}}$ & $88,35^{\mathrm{Aa}}$ & $91,50^{\mathrm{Aa}}$ & $93,75^{\mathrm{Aa}}$ & $96,45^{\mathrm{Aa}}$ \\
& $(12,51-39,46)$ & $(20,99-32,41)$ & $(53,85-101,15)$ & $(53,31-103,83)$ & $(77,90-101,13)$ & $(86,98-101,45)$ \\
M3 & $24,60^{\mathrm{Aa}}$ & $27,00^{\mathrm{Aa}}$ & $83,45^{\mathrm{Aa}}$ & $73,55^{\mathrm{Aa}}$ & $94,85^{\mathrm{Aa}}$ & $95,10^{\mathrm{Aa}}$ \\
& $(14,36-44,34)$ & $(16,41-36,66)$ & $(46,24-100,76)$ & $(34,67-95,39)$ & $(74,78-101,72)$ & $(84,42-99,51)$ \\
M4 & $16,85^{\mathrm{Aa}}$ & $19,25^{\mathrm{Aa}}$ & $85,25^{\mathrm{Aa}}$ & $90,65^{\mathrm{Aa}}$ & $97,30^{\mathrm{Aa}}$ & $95,70^{\mathrm{Aa}}$ \\
& $(14,06-22,04)$ & $(14,40-25,13)$ & $(80,27-91,69)$ & $(88,44-93,39)$ & $(84,34-101,75)$ & $(89,31-100,26)$ \\
\hline
\end{tabular}

M1: Antes da inoculação, M2: Momento das manifestações clínicas, M3: Um dia após o fim do tratamento, M4: Uma semana após o fim do tratamento

G1: norfloxacina associada a flunixina meglumina; G2: somente norfloxacina

Letras Maiúsculas diferentes indicam $\mathrm{P} \leq 0,05$ entre os momentos experimentais.

Letras Minúsculas diferentes indicam $\mathrm{P} \leq 0,05$ entre os grupos. 
Tabela 17 - Medianas e intervalos de confiança das porcentagens das subpopulações de linfócitos T identificadas por citometria de fluxo no sangue de bezerros durante os quatro momentos da infecção experimental por Mannheimia haemolytica - São Paulo - 2014

\begin{tabular}{|c|c|c|c|c|c|c|c|c|c|c|}
\hline \multirow[t]{2}{*}{ Tempo } & \multicolumn{2}{|c|}{ Leucócitos CD3+ } & \multicolumn{2}{|c|}{$\begin{array}{c}\mathrm{CD} 3+ \\
\mathrm{CD} 4+/ \mathrm{CD} 8=\end{array}$} & \multicolumn{2}{|c|}{$\begin{array}{c}\mathrm{CD} 3+ \\
\mathrm{CD} 4+/ \mathrm{CD} 8+\end{array}$} & \multicolumn{2}{|c|}{$\begin{array}{c}\mathrm{CD} 3+ \\
\mathrm{CD} 4-/ \mathrm{CD} 8+\end{array}$} & \multicolumn{2}{|c|}{$\begin{array}{c}\mathrm{CD} 3+ \\
\mathrm{CD} 4-/ \mathrm{CD} 8=\end{array}$} \\
\hline & G1 & G2 & G1 & G2 & G1 & G2 & G1 & G2 & G1 & G2 \\
\hline \multirow{3}{*}{ M1 } & $49,00^{\mathrm{Aa}}$ & $50,50^{\mathrm{Aa}}$ & $12,23^{\mathrm{Aa}}$ & $8,85^{\mathrm{Aa}}$ & $1,71^{\mathrm{Aa}}$ & $1,04^{\mathrm{Aa}}$ & $9,79^{\mathrm{Aa}}$ & $9,04^{\mathrm{ABa}}$ & $15,42^{\mathrm{ABa}}$ & $26,77^{\text {Аa }}$ \\
\hline & $\begin{array}{c}(38,52- \\
55,05)\end{array}$ & $\begin{array}{c}(45,56- \\
56,60)\end{array}$ & $\begin{array}{l}(2,52- \\
17,84)\end{array}$ & $\begin{array}{l}(2,47- \\
13,34)\end{array}$ & $\begin{array}{c}(0,45- \\
3,28)\end{array}$ & $\begin{array}{c}(0,006- \\
3,00)\end{array}$ & $\begin{array}{l}(3,30- \\
31,00)\end{array}$ & $\begin{array}{l}(1,91- \\
27,77)\end{array}$ & $\begin{array}{l}(11,77- \\
22,92)\end{array}$ & $\begin{array}{c}(17,49- \\
36,16)\end{array}$ \\
\hline & $30,45^{\mathrm{Ba}}$ & $38,95^{\mathrm{Ba}}$ & $6,93^{\mathrm{Aa}}$ & $8,81^{\mathrm{Aa}}$ & $0,70^{\mathrm{Aa}}$ & $0,71^{\mathrm{Aa}}$ & $6,17^{\mathrm{Aa}}$ & $5,67^{\mathrm{Ba}}$ & $12,76^{\mathrm{Bb}}$ & $22,43^{\mathrm{Aa}}$ \\
\hline \multirow[t]{2}{*}{ M2 } & $\begin{array}{c}(14,25- \\
44,62)\end{array}$ & $\begin{array}{c}(25,33- \\
49,63)\end{array}$ & $\begin{array}{l}(1,37- \\
15,54)\end{array}$ & $\begin{array}{l}(3,49- \\
11,30)\end{array}$ & $\begin{array}{c}(-0,13- \\
2,90)\end{array}$ & $\begin{array}{c}(0,23- \\
2,04)\end{array}$ & $\begin{array}{l}(2,41- \\
12,75)\end{array}$ & $\begin{array}{c}(3,85- \\
9,01)\end{array}$ & $\begin{array}{l}(5,46- \\
18,53)\end{array}$ & $\begin{array}{c}(13,89- \\
31,12)\end{array}$ \\
\hline & $39,70^{\mathrm{ABb}}$ & $47,45^{\mathrm{ABa}}$ & $0,95^{\text {Aa }}$ & $4,30^{\mathrm{Aa}}$ & $0,35^{\mathrm{Aa}}$ & $0,23^{\mathrm{Aa}}$ & $10,34^{\mathrm{Aa}}$ & $8,73^{\mathrm{Aa}}$ & $22,64^{\mathrm{Aa}}$ & $34,64^{\mathrm{Aa}}$ \\
\hline \multirow[t]{2}{*}{ M3 } & $\begin{array}{c}(27,54- \\
46,89)\end{array}$ & $\begin{array}{c}(39,70- \\
58,90)\end{array}$ & $\begin{array}{c}(-2,01- \\
9,82)\end{array}$ & $\begin{array}{c}(0,20- \\
8,82)\end{array}$ & $\begin{array}{c}(-0,47- \\
2,55)\end{array}$ & $\begin{array}{c}(-0,03- \\
0,54)\end{array}$ & $\begin{array}{l}(7,74- \\
14,99)\end{array}$ & $\begin{array}{l}(6,01- \\
12,55)\end{array}$ & $\begin{array}{c}(10,02- \\
31,78)\end{array}$ & $\begin{array}{c}(24,45- \\
46,03)\end{array}$ \\
\hline & $45,55^{\mathrm{Aa}}$ & $49,15^{\mathrm{ABa}}$ & $10,74^{\mathrm{Aa}}$ & $7,59^{\mathrm{Aa}}$ & $1,55^{\mathrm{Aa}}$ & $0,36^{\mathrm{Aa}}$ & $11,33^{\mathrm{Aa}}$ & $8,57^{\mathrm{ABa}}$ & $16,67^{\mathrm{ABa}}$ & $29,40^{\text {Aa }}$ \\
\hline M4 & $\begin{array}{c}(33,35- \\
56,89)\end{array}$ & $\begin{array}{c}(40,78- \\
57,48)\end{array}$ & $\begin{array}{l}(-1,63- \\
26,05)\end{array}$ & $\begin{array}{l}(0,73- \\
12,06)\end{array}$ & $\begin{array}{c}(-0,41- \\
4,24)\end{array}$ & $\begin{array}{l}(-1,49- \\
4,32)\end{array}$ & $\begin{array}{l}(8,85- \\
15,49)\end{array}$ & $\begin{array}{l}(6,43- \\
11,88)\end{array}$ & $\begin{array}{l}(7,13- \\
30,52)\end{array}$ & $\begin{array}{c}(20,49- \\
43,80)\end{array}$ \\
\hline$P$ & 0,0023 & 0,008 & 0,23 & 0,99 & 0,45 & 0,49 & 0,07 & 0,04 & 0,04 & 0,08 \\
\hline
\end{tabular}

M1: Antes da inoculação, M2: Momento das manifestações clínicas, M3: Um dia após o fim do tratamento, M4: Uma semana após o fim do tratamento

G1: norfloxacina associada a flunixina meglumina; G2: somente norfloxacina

Letras Maiúsculas diferentes indicam $\mathrm{P} \leq 0,05$ entre os momentos experimentais.

Letras Minúsculas diferentes indicam $\mathrm{P} \leq 0,05$ entre os grupos.

Quando as populações leucocitárias presentes no sangue dos bezerros utilizados na pesquisa foram analisadas, inferiu-se que a infecção e o tratamento não influenciaram as populações de monócitos (Tabela 15) e de granulócitos (Tabela 16), porém observou-se redução das populações de linfócitos $\mathrm{T} \mathrm{CD}^{+}$no $\mathrm{M} 2$ em relação a M1 e M4 no G1 e M1 no G2. Houve maior porcentagem de linfócitos $\mathrm{T} \mathrm{CD} 3^{+}$no $\mathrm{M} 3$ no $\mathrm{G} 2$. Quanto à população de linfócitos $\mathrm{T}$ gama-delta $\left(\mathrm{CD}^{-} / \mathrm{CD}^{-}\right)$e $\mathrm{T} \mathrm{CD}^{+}$houve aumento no $\mathrm{M} 2$ em relação ao $\mathrm{M} 3$ no G1 e G2, respectivamente. Além disso, observou-se maior porcentagem de linfócitos gamadelta no M2 no G2 (Tabela 17).

Considerando o fato das citocinas contribuírem com a migração de neutrófilos para o pulmão, foi realizada também a quantificação da expressão de CD62L pelos granulócitos sanguíneos durante os distintos momentos da infecção experimental por M. haemolytica, que estão apresentadas na Tabela 18 a seguir. 
Tabela 18 - Médias e erros padrão das porcentagens de granulócitos $\mathrm{CH} 138^{+}$que expressaram CD62L identificadas por citometria de fluxo no sangue de bezerros durante os quatro momentos da infecção experimental por Mannheimia haemolytica - São Paulo - 2014

\begin{tabular}{ccc}
\hline Tempo & Porcentagem de leucócitos CH138+ que expressam CD62L \\
\hline & G1 & G2 \\
M1 & $96,45^{\mathrm{Aa}^{*}}$ & $95,55^{\mathrm{Aa}}$ \\
& $(89,84-99,86)$ & $(87,73-99,47)$ \\
M2 & $55,55^{\mathrm{Aa}}$ & $72,90^{\mathrm{Ba}}$ \\
& $(29,63-91,99)$ & $(38,70-87,10)$ \\
M3 & $70,25^{\mathrm{Aa}}$ & $73,75^{\mathrm{ABa}}$ \\
& $(53,78-93,85)$ & $(57,26-95,70)$ \\
M4 & $77,25^{\mathrm{Aa}}$ & $84,65^{\mathrm{ABa}}$ \\
P & $(64,03-93,90)$ & $(79,08-91,52)$ \\
\hline
\end{tabular}

M1: Antes da inoculação, M2: Momento das manifestações clínicas, M3: Um dia após o fim do tratamento, M4: Uma semana após o fim do tratamento

G1: norfloxacina associada a flunixina meglumina; G2: somente norfloxacina

Letras Maiúsculas diferentes indicam $\mathrm{P} \leq 0,05$ entre os momentos experimentais.

Letras Minúsculas diferentes indicam $\mathrm{P} \leq 0,05$ entre os grupos.

$* \mathrm{P}=0,08$ indica tendência entre os momentos

A porcentagem de neutrófilos que expressaram CD62L foi menor no M2 quando comparada ao M1 no G2, e no G1 foi observado tendência ao mesmo comportamento.

\subsubsection{Provas funcionais dos fagócitos do sangue}

Nas tabelas 19 a 22 estão representados os valores medianos e do intervalo de confiança da porcentagem de células $\mathrm{CD}_{1} 4^{+}$do sangue, que produziram ERO intracelular, e de sua IMF basal e estimulado por M. haemolytica, S. aureus e E. Coli, respectivamente. 
Tabela 19 - Valores medianos e dos intervalos de confiança da produção de espécies reativas de oxigênio basal e intensidade de fluorescência em valores arbitrários por células $\mathrm{CD}_{14}{ }^{+}$no sangue de bezerros durante os quatro momentos da infecção experimental por Mannheimia haemolytica - São Paulo - 2014

\begin{tabular}{|c|c|c|c|c|}
\hline \multirow{3}{*}{ Tempo } & \multicolumn{4}{|c|}{ Sem estimulo } \\
\hline & \multicolumn{2}{|c|}{ Produção de ERO (\%) } & \multicolumn{2}{|c|}{ Intensidade de Fluorescência } \\
\hline & G1 & G2 & G1 & G2 \\
\hline M1 & $\begin{array}{c}72,25^{\mathrm{ABa}} \\
(60,06-85,97)\end{array}$ & $\begin{array}{c}64,20^{\mathrm{Ba}} \\
(52,99-85,47)\end{array}$ & $\begin{array}{c}22,00^{\mathrm{ABa}} \\
(8,38-33,67)\end{array}$ & $\begin{array}{c}17,70^{\mathrm{Ba}} \\
(7,46-30,03)\end{array}$ \\
\hline M2 & $\begin{array}{c}94,55^{\mathrm{Aa}} \\
(81,58-100,45)\end{array}$ & $\begin{array}{c}92,60^{\mathrm{Aa}} \\
(82,77-98,36)\end{array}$ & $\begin{array}{c}114,05^{\mathrm{Aa}} \\
(-14,01-397,26)\end{array}$ & $\begin{array}{c}137,50^{\mathrm{Aa}} \\
(81,33-216-87)\end{array}$ \\
\hline M3 & $\begin{array}{c}88,55^{\mathrm{ABa}} \\
(69,05-94,27)\end{array}$ & $\begin{array}{c}84,00^{\mathrm{ABa}} \\
(68,95-99,13)\end{array}$ & $\begin{array}{c}14,10^{\mathrm{Ba}} \\
(11,48-18,15)\end{array}$ & $\begin{array}{c}32,95^{\mathrm{ABa}} \\
(19,05-45,48)\end{array}$ \\
\hline M4 & $\begin{array}{c}68,85^{\mathrm{Ba}} \\
(49,64-80,88)\end{array}$ & $\begin{array}{c}70,15^{\mathrm{Ba}} \\
(62,19-74,74)\end{array}$ & $\begin{array}{c}10,37^{\mathrm{Ba}} \\
(2,28-20,60)\end{array}$ & $\begin{array}{c}12,85^{\mathrm{Ba}} \\
(4,25-19,83)\end{array}$ \\
\hline$P$ & 0,0028 & 0,0015 & 0,0015 & 0,0001 \\
\hline
\end{tabular}

M1: Antes da inoculação, M2: Momento das manifestações clínicas, M3: Um dia após o fim do tratamento, M4: Uma semana após o fim do tratamento

G1: norfloxacina associada a flunixina meglumina; G2: somente norfloxacina Letras Maiúsculas diferentes indicam $\mathrm{P} \leq 0,05$ entre os momentos experimentais. Letras Minúsculas diferentes indicam $\mathrm{P} \leq 0,05$ entre os grupos

Tabela 20 - Valores medianos e dos intervalos de confiança da produção de espécies reativas de oxigênio e intensidade de fluorescência em valores arbitrários por células $\mathrm{CD}_{14}{ }^{+}$no sangue de bezerros estimulados por Mannheimia haemolytica durante os quatro momentos da infecção experimental por Mannheimia haemolytica - São Paulo - 2014

\begin{tabular}{|c|c|c|c|c|}
\hline \multirow{3}{*}{ Tempo } & \multicolumn{4}{|c|}{ Estimulado por M. haemolytica } \\
\hline & \multicolumn{2}{|c|}{ Produção de ERO (\%) } & \multicolumn{2}{|c|}{ Intensidade de Fluorescência } \\
\hline & G1 & G2 & G1 & G2 \\
\hline M1 & $\begin{array}{c}65,00^{\mathrm{Aa}} \\
(25,25-97,71)\end{array}$ & $\begin{array}{c}76,35^{\mathrm{Aa}} \\
(29,56-103,87)\end{array}$ & $\begin{array}{c}18,70^{\mathrm{Aa}} \\
(7,22-32,17)\end{array}$ & $\begin{array}{c}17,20^{\mathrm{Aa}} \\
(1,01-48,71)\end{array}$ \\
\hline M2 & $\begin{array}{c}95,82^{\mathrm{Aa}} \\
(84,52-101,34)\end{array}$ & $\begin{array}{c}93,08^{\mathrm{Aa}} \\
(83,42-100,63)\end{array}$ & $\begin{array}{c}46,35^{\mathrm{Aa}} \\
(21,58-74,78)\end{array}$ & $\begin{array}{c}61,30^{\mathrm{Aa}} \\
(14,57-119,5)\end{array}$ \\
\hline M3 & $\begin{array}{c}80,97^{\mathrm{Aa}} \\
(45,65-97,50)\end{array}$ & $\begin{array}{c}57,54^{\text {Aa }} \\
(31,73-84-24)\end{array}$ & $\begin{array}{c}28,40^{\mathrm{Aa}} \\
(12,65-55,14)\end{array}$ & $\begin{array}{c}20,30^{\mathrm{Aa}} \\
(7,60-36,16)\end{array}$ \\
\hline M4 & $\begin{array}{c}63,30^{\mathrm{Aa}} \\
(53,07-79,90)\end{array}$ & $\begin{array}{c}55,35^{\mathrm{Aa}} \\
(32,56-75,43)\end{array}$ & $\begin{array}{c}21,40^{\mathrm{Aa}} \\
(11,21-32,10)\end{array}$ & $\begin{array}{c}22,70^{\mathrm{Aa}} \\
(10,76-38,82)\end{array}$ \\
\hline P & 0,23 & 0,09 & 0,37 & 0,51 \\
\hline
\end{tabular}

M1: Antes da inoculação, M2: Momento das manifestações clínicas, M3: Um dia após o fim do tratamento, M4: Uma semana após o fim do tratamento

G1: norfloxacina associada a flunixina meglumina; G2: somente norfloxacina

Letras Maiúsculas diferentes indicam $\mathrm{P} \leq 0,05$ entre os momentos experimentais.

Letras Minúsculas diferentes indicam $\mathrm{P} \leq 0,05$ entre os grupos 
Tabela 21 - Valores medianos e dos intervalos de confiança da produção de espécies reativas de oxigênio e intensidade de fluorescência em valores arbitrários por células $\mathrm{CD}_{14}{ }^{+}$no sangue de bezerros estimulados por Staphylococcus aureus durante os quatro momentos da infecção experimental por Mannheimia haemolytica - São Paulo - 2014

\begin{tabular}{|c|c|c|c|c|}
\hline \multirow{3}{*}{ Tempo } & \multicolumn{4}{|c|}{ Estimulado por S. aureus } \\
\hline & \multicolumn{2}{|c|}{ Produção de ERO (\%) } & \multicolumn{2}{|c|}{ Intensidade de Fluorescência } \\
\hline & G1 & G2 & G1 & G2 \\
\hline M1 & $\begin{array}{c}89,15^{\mathrm{ABa}} \\
(80,40-99,11)\end{array}$ & $\begin{array}{c}95,05 \text { Aa } \\
(66,56-104,17)\end{array}$ & $\begin{array}{c}14,25^{\mathrm{Ba}} \\
(8,39-28,54)\end{array}$ & $\begin{array}{c}12,00^{\mathrm{Ba}} \\
(1,69-3,01)\end{array}$ \\
\hline M2 & $\begin{array}{c}97,95^{\mathrm{Aa}} \\
(86,09-103,00)\end{array}$ & $\begin{array}{c}94,20^{\mathrm{Aa}} \\
(83,63-101,34)\end{array}$ & $\begin{array}{c}73,25^{\mathrm{Aa}} \\
(13,67-162,66)\end{array}$ & $\begin{array}{c}72,25^{\mathrm{Aa}} \\
(21,66-153,24)\end{array}$ \\
\hline M3 & $\begin{array}{c}83,60^{\mathrm{ABa}} \\
(64,50-97,57)\end{array}$ & $\begin{array}{c}71,35^{\mathrm{ABa}} \\
(57,32-89,07)\end{array}$ & $\begin{array}{c}26,45^{\mathrm{ABa}} \\
(8,45-67,01)\end{array}$ & $\begin{array}{c}28,95^{\mathrm{ABa}} \\
(14,09-49,97)\end{array}$ \\
\hline M4 & $\begin{array}{c}32,42^{\mathrm{Ba}} \\
(17,80-59,08)\end{array}$ & $\begin{array}{c}43,21^{\mathrm{Ba}} \\
(21,96-77,24)\end{array}$ & $\begin{array}{c}14,35^{\mathrm{Ba}} \\
(3,95-30,10)\end{array}$ & $\begin{array}{c}18,60^{\mathrm{Ba}} \\
(6,77-34,60)\end{array}$ \\
\hline P & 0,01 & 0,002 & 0,01 & 0,05 \\
\hline
\end{tabular}

M1: Antes da inoculação, M2: Momento das manifestações clínicas, M3: Um dia após o fim do tratamento, M4: Uma semana após o fim do tratamento

G1: norfloxacina associada a flunixina meglumina; G2: somente norfloxacina

Letras Maiúsculas diferentes indicam $\mathrm{P} \leq 0,05$ entre os momentos experimentais.

Letras Minúsculas diferentes indicam $\mathrm{P} \leq 0,05$ entre os grupos

Tabela 22 - Valores percentuais das medianas e dos intervalos de confiança da produção de espécies reativas de oxigênio e intensidade de fluorescência em valores arbitrários por células $\mathrm{CD}_{1} 4^{+}$no sangue de bezerros estimulados por Escherichia coli durante os quatro momentos da infecção experimental por Mannheimia haemolytica - São Paulo - 2014

\begin{tabular}{|c|c|c|c|c|}
\hline \multirow{3}{*}{ Tempo } & \multicolumn{4}{|c|}{ Estimulado por E. coli } \\
\hline & \multicolumn{2}{|c|}{ Produção de ERO (\%) } & \multicolumn{2}{|c|}{ Intensidade de Fluorescência } \\
\hline & G1 & G2 & G1 & G2 \\
\hline M1 & $\begin{array}{c}71,30^{\mathrm{ABa}} \\
(60,51-94,02)\end{array}$ & $\begin{array}{c}86,45^{\mathrm{Aa}} \\
(75,76-97,78)\end{array}$ & $\begin{array}{c}15,15^{\text {Aa }} \\
(5,09-48,27)\end{array}$ & $\begin{array}{c}16,90^{\mathrm{Aa}} \\
(4,68-50,77)\end{array}$ \\
\hline M2 & $\begin{array}{c}97,50^{\mathrm{Aa}} \\
(92,54-99,62)\end{array}$ & $\begin{array}{c}95,59^{\mathrm{Aa}} \\
(87,18-99,11)\end{array}$ & $\begin{array}{c}29,70^{\mathrm{Aa}} \\
(11,30-55,96)\end{array}$ & $\begin{array}{c}22,15^{\mathrm{Aa}} \\
(5,60-57,26)\end{array}$ \\
\hline M3 & $\begin{array}{c}78,14^{\mathrm{ABa}} \\
(68,53-91,01)\end{array}$ & $\begin{array}{c}67,06^{\mathrm{ABa}} \\
(49,71-87,18)\end{array}$ & $\begin{array}{c}40,00^{\mathrm{Aa}} \\
(14,03-75,43)\end{array}$ & $\begin{array}{c}24,05^{\mathrm{Aa}} \\
(16,51-38,02)\end{array}$ \\
\hline M4 & $\begin{array}{c}26,33^{\mathrm{Ba}} \\
(10,87-43,92)\end{array}$ & $\begin{array}{c}35,49^{\mathrm{Ba}} \\
(20,06-45,26)\end{array}$ & $\begin{array}{c}14,75^{\mathrm{Aa}} \\
(6,77-25,28)\end{array}$ & $\begin{array}{c}16,50^{\mathrm{Aa}} \\
(8,32-24,31)\end{array}$ \\
\hline P & 0,0006 & $<0,0001$ & 0,66 & 0,77 \\
\hline
\end{tabular}

M1: Antes da inoculação, M2: Momento das manifestações clínicas, M3: Um dia após o fim do tratamento, M4: Uma semana após o fim do tratamento

G1: norfloxacina associada a flunixina meglumina; G2: somente norfloxacina

Letras Maiúsculas diferentes indicam $\mathrm{P} \leq 0,05$ entre os momentos experimentais.

Letras Minúsculas diferentes indicam $\mathrm{P} \leq 0,05$ entre os grupos

A porcentagem de células $\mathrm{CD}_{1} 4^{+}$que produziram ERO sem estimulo foi maior no M2 que M4 em ambos os grupos, e também maior que M1, no G2. Similarmente a IMF da 
produção de ERO pelas $\mathrm{CD}_{14}{ }^{+}$foi maior em M2 que M4 em ambos os grupos, e maior que M3 e M1 no G1 e G2, respectivamente. Não foi observado diferença significativa na produção intracelular de ERO nas células $\mathrm{CD}_{1} 4^{+}$por $M$. haemolytica. A porcentagem de células $\mathrm{CD}_{14}{ }^{+}$que produziram ERO estimuladas por $S$. aureus ou E. coli foi maior no M4 que M2 em ambos os grupos, e maior que M1, no G2. A IMF de produção de ERO pelas células $\mathrm{CD}_{14}{ }^{+}$estimuladas por $S$. aureus foi maior no M2 que M1 e M4, em ambos os grupos.

Nas tabelas 23 a 26 estão representados os valores medianos e dos intervalos de confiança da porcentagem de células $\mathrm{CH} 138^{+}$do sangue que produziram ERO intracelular e de sua IMF basal e estimulado por M. haemolytica, S. aureus e E. coli, respectivamente.

Tabela 23 - Valores medianos e dos intervalos de confiança da produção de espécies reativas de oxigênio basal e intensidade de fluorescência em valores arbitrários por células $\mathrm{CH}_{138^{+}}$no sangue de bezerros durante os quatro momentos da infecção experimental por Mannheimia haemolytica - São Paulo - 2014

\begin{tabular}{|c|c|c|c|c|}
\hline \multirow{3}{*}{ Tempo } & \multicolumn{4}{|c|}{ Sem estímulo } \\
\hline & \multicolumn{2}{|c|}{ Produção de ERO (\%) } & \multicolumn{2}{|c|}{ Intensidade de Fluorescência } \\
\hline & G1 & G2 & G1 & G2 \\
\hline \multirow{2}{*}{ M1 } & $98,95^{\mathrm{Aa}}$ & $99,45^{\text {Aa }}$ & $226,00^{\mathrm{ABa}}$ & $275,50^{\mathrm{Ba}}$ \\
\hline & $(97,54-100,03)$ & $(70,28-111,39)$ & $(134,91-519,76)$ & $(59,64-786,69)$ \\
\hline \multirow{2}{*}{ M2 } & $96,75^{\mathrm{Aa}}$ & $98,10^{\mathrm{Aa}}$ & $981,00^{\mathrm{Aa}}$ & $1492,00^{\mathrm{Aa}}$ \\
\hline & $(94,26-99,28)$ & $(94,33-100,47)$ & $(402,65-2350,00)$ & $(910,43-1935,60)$ \\
\hline \multirow{2}{*}{ M3 } & $98,85^{\mathrm{Aa}}$ & $99,00^{\mathrm{Aa}}$ & $186,50^{\mathrm{Bb}}$ & $360,50^{\mathrm{ABa}}$ \\
\hline & $(90,84-101,29)$ & $(96,57-100,16)$ & $(133,66-247,34)$ & $(172,20-719,47)$ \\
\hline \multirow{2}{*}{ M4 } & $98,60^{\mathrm{Aa}}$ & $96,95^{\mathrm{Aa}}$ & $209,50^{\mathrm{Ba}}$ & $208,00^{\mathrm{Ba}}$ \\
\hline & $(78,85-107,18)$ & $(89,04-100,99)$ & $(44,14-354,39)$ & $(52,35-339,82)$ \\
\hline $\mathbf{P}$ & 0,49 & 0,39 & 0,0033 & 0,0003 \\
\hline
\end{tabular}

M1: Antes da inoculação, M2: Momento das manifestações clínicas, M3: Um dia após o fim do tratamento, M4: Uma semana após o fim do tratamento

G1: norfloxacina associada a flunixina meglumina; G2: somente norfloxacina

Letras Maiúsculas diferentes indicam $\mathrm{P} \leq 0,05$ entre os momentos experimentais.

Letras Minúsculas diferentes indicam $\mathrm{P} \leq 0,05$ entre os grupos 
Tabela 24 - Valores medianos e dos intervalos de confiança da produção de espécies reativas de oxigênio e intensidade de fluorescência em valores arbitrários por células granulocíticas no sangue de bezerros estimulados por Mannheimia haemolytica durante os quatro momentos da infecção experimental por Mannheimia haemolytica São Paulo - 2014

\begin{tabular}{ccccc}
\hline \multirow{2}{*}{ Tempo } & \multicolumn{4}{c}{ Estimulado por M. haemolytica } \\
\cline { 2 - 5 } & \multicolumn{2}{c}{ Produção de ERO $(\%)$} & Intensidade de Fluorescência \\
\multirow{2}{*}{ M1 } & G1 & G2 & G1 & G2 \\
& $88,45^{\mathrm{Aa}}$ & $93,95^{\mathrm{Aa}}$ & $289,00^{\mathrm{ABa}}$ & $320,70^{\mathrm{Aa}}$ \\
\multirow{2}{*}{ M2 } & $(82,77-97,29)$ & $(88,30-98,17)$ & $(67,26-594,77)$ & $(171,84-565,19)$ \\
& $94,37^{\mathrm{Aa}}$ & $96,03^{\mathrm{Aa}}$ & $1048,00^{\mathrm{Aa}}$ & $1018,00^{\mathrm{Aa}}$ \\
\multirow{2}{*}{ M3 } & $(90,54-99,38)$ & $(82,62-101,81)$ & $(564,88-1427,8)$ & $(420,16-1370,50)$ \\
& $92,90^{\mathrm{Aa}}$ & $90,80^{\mathrm{Aa}}$ & $540,00^{\mathrm{ABa}}$ & $621,00^{\mathrm{Aa}}$ \\
M4 & $(88,04-97,37)$ & $(78,98-98,79)$ & $(348,62-671,05)$ & $(419,94-999,06)$ \\
& $93,20^{\mathrm{Aa}}$ & $93,60^{\mathrm{Aa}}$ & $254,70^{\mathrm{Ba}}$ & $273,45^{\mathrm{Aa}}$ \\
P & $(84,33-97,77)$ & $(90,52-97,08)$ & $(167,11-414,06)$ & $(47,91-763,79)$ \\
\hline
\end{tabular}

M1: Antes da inoculação, M2: Momento das manifestações clínicas, M3: Um dia após o fim do tratamento, M4: Uma semana após o fim do tratamento

G1: norfloxacina associada a flunixina meglumina; G2: somente norfloxacina

Letras Maiúsculas diferentes indicam $\mathrm{P} \leq 0,05$ entre os momentos experimentais.

Letras Minúsculas diferentes indicam $\mathrm{P} \leq 0,05$ entre os grupos

Tabela 25 - Valores medianos e dos intervalos de confiança da produção de espécies reativas de oxigênio e intensidade de fluorescência em valores arbitrários por células granulocíticas no sangue de bezerros estimulados por Staphylococcus aureus durante os quatro momentos da infecção experimental por Mannheimia haemolytica - São Paulo - 2014

\begin{tabular}{ccccc}
\hline \multirow{2}{*}{ Tempo } & \multicolumn{4}{c}{ Estimulado por S. aureus } \\
\cline { 2 - 5 } & \multicolumn{2}{c}{ Produção de ERO $(\%)$} & Intensidade de Fluorescência \\
\multirow{2}{*}{ M1 } & G1 & G2 & G1 & G2 \\
& $84,22^{\mathrm{Aa}}$ & $97,08^{\mathrm{Aa}}$ & $316,50^{\mathrm{Ba}}$ & $359,00^{\mathrm{Ba}}$ \\
\multirow{2}{*}{ M2 } & $(57,39-102,29)$ & $(70,67-106,28)$ & $(246,23-432,44)$ & $(271,27-431,73)$ \\
& $84,15^{\mathrm{Aa}}$ & $88,70^{\mathrm{Aa}}$ & $1520,5^{\mathrm{Aa}}$ & $1145,0^{\mathrm{Aa}}$ \\
\multirow{2}{*}{ M3 } & $(74,51-98,16)$ & $(65,65-100,18)$ & $(1056,8-2009,2)$ & $(806,98-1985,0)$ \\
& $87,50^{\mathrm{Aa}}$ & $90,70^{\mathrm{Aa}}$ & $382,50^{\mathrm{Ba}}$ & $387,50^{\mathrm{Ba}}$ \\
\multirow{2}{*}{ M4 } & $(73,06-98,44)$ & $(78,51-100,16)$ & $(175,58-695,09)$ & $(308,75-591,25)$ \\
& $86,10^{\mathrm{Aa}}$ & $89,45^{\mathrm{Aa}}$ & $708,00^{\mathrm{ABa}}$ & $643,50^{\mathrm{ABa}}$ \\
& $(70,62-94,58)$ & $(82,64-95,65)$ & $(433,57-969,77)$ & $(195,05-927,29)$ \\
\hline
\end{tabular}

M1: Antes da inoculação, M2: Momento das manifestações clínicas, M3: Um dia após o fim do tratamento, M4: Uma semana após o fim do tratamento

G1: norfloxacina associada a flunixina meglumina; $\mathrm{G} 2$ : somente norfloxacina

Letras Maiúsculas diferentes indicam $\mathrm{P} \leq 0,05$ entre os momentos experimentais.

Letras Minúsculas diferentes indicam $\mathrm{P} \leq 0,05$ entre os grupos 
Tabela 26 - Valores medianos e dos intervalos de confiança da produção de espécies reativas de oxigênio e intensidade de fluorescência em valores arbitrários por células granulocíticas no sangue de bezerros estimulados por Escherichia coli durante os quatro momentos da infecção experimental por Mannheimia haemolytica - São Paulo - 2014

\begin{tabular}{ccccc}
\hline \multirow{2}{*}{ Tempo } & \multicolumn{4}{c}{ Estimulado por E.coli } \\
\cline { 2 - 5 } Grupos & Produção de ERO $(\%)$ & Intensidade de Fluorescência \\
M1 & G1 & G2 & G1 & G2 \\
& $94,70^{\mathrm{Aa}}$ & $95,15^{\mathrm{Aa}}$ & $256,00^{\mathrm{Aa}}$ & $255,00^{\mathrm{Aa}}$ \\
\multirow{2}{*}{ M1 } & $(88,29-99,36)$ & $(92,20-98,09)$ & $(119,40-456,27)$ & $(119,60-595,74)$ \\
& $87,24^{\mathrm{Aa}}$ & $86,68^{\mathrm{Aa}}$ & $674,50^{\mathrm{Aa}}$ & $540,50^{\mathrm{Aa}}$ \\
\multirow{2}{*}{ M3 } & $(83,10-98,07)$ & $(72,86-99,36)$ & $(217,75-1211,3)$ & $(209,72-905-28)$ \\
& $92,05^{\mathrm{Aa}}$ & $88,10^{\mathrm{Aa}}$ & $314,50^{\mathrm{Aa}}$ & $372,00^{\mathrm{Aa}}$ \\
M4 & $(85,26-97,09)$ & $(67,63-100,17)$ & $(104,38-730,95)$ & $(244,87-450,80)$ \\
& $87,25^{\mathrm{Aa}}$ & $94,95^{\mathrm{Aa}}$ & $356,00^{\mathrm{Aa}}$ & $521,00^{\mathrm{Aa}}$ \\
P & $(77,00-95,59)$ & $(90.03-98,30)$ & $(212,77-634,90)$ & $(317,59-670,74)$ \\
\hline
\end{tabular}

M1: Antes da inoculação, M2: Momento das manifestações clínicas, M3: Um dia após o fim do tratamento, M4: Uma semana após o fim do tratamento

G1: norfloxacina associada a flunixina meglumina; G2: somente norfloxacina

Letras Maiúsculas diferentes indicam $\mathrm{P} \leq 0,05$ entre os momentos experimentais.

Letras Minúsculas diferentes indicam $\mathrm{P} \leq 0,05$ entre os grupos

Não foram observadas diferenças significativas na porcentagem de granulócitos que produziram ERO, com e sem estímulo. No entanto, a IMF da produção de ERO basal por granulócitos foi maior no M2 que M4, em ambos os grupos e maior que M1, no G2. Do mesmo modo a IMF da produção de ERO M. haemolytica foi maior em M2 que M4, no G1. Quando estimuladas por $S$. aureus a IMF da produção de ERO por granulócitos foi maior em M2 que M1 e M3, em ambos os grupos. Não houve diferença na produção de ERO pelos granulócitos estimulados por E. coli.

Quando comparadas a porcentagem de produção de ERO pelos granulócitos do sangue, entre os estímulos utilizados foi observada diferença no G1, onde a produção de ERO foi maior no grupo não estimulado em relação aos três estímulos e entre o estímulo por $M$. haemolytica e $S$. aureus, onde a primeira produziu mais ERO que a segunda $(\mathrm{P}=0,0006)$ (Gráfico 3). 
Gráfico 3 - Box Plot das médias e dos erros padrão da porcentagem de granulócitos do sangue que produziram espécies reativas de oxigênio nos animais do Grupo 1 não estimulados e estimulados por bactérias - São Paulo - 2014

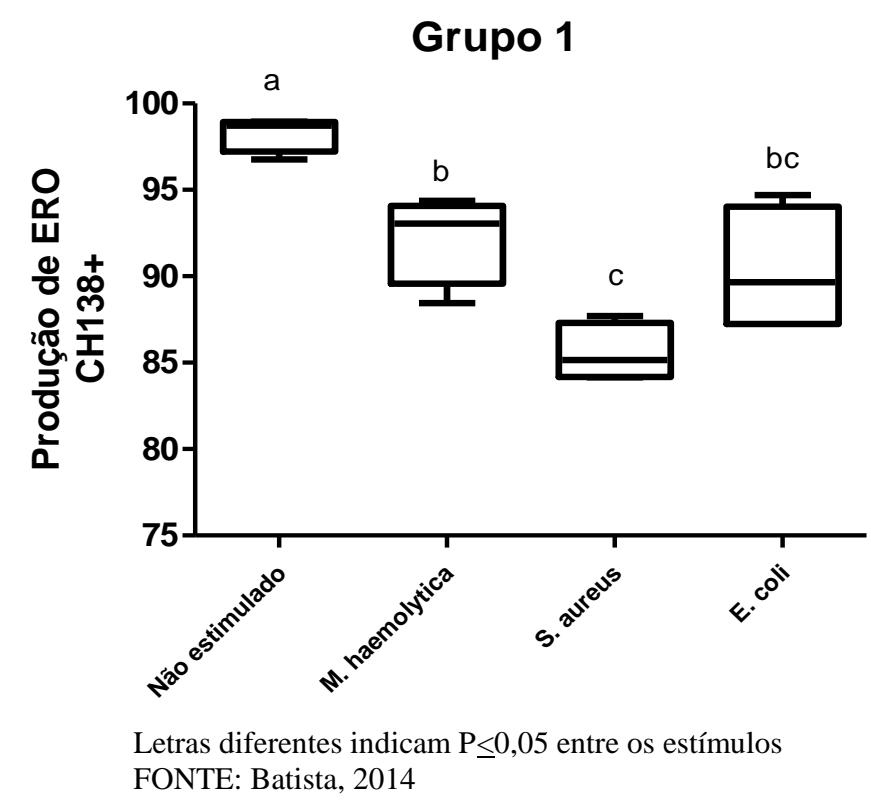

Diferença também observada no G2 (Gráfico 4), entretanto somente entre as células não estimuladas e as estimuladas por $S$. aureus e $E$. coli, onde as células não estimuladas produziram mais ERO em relação aos estímulos por essas duas bactérias $(\mathrm{P}=0,02)$.

Gráfico 4 - Box Plot das médias e dos erros padrão da porcentagem de granulócitos do sangue que produziram espécies reativas de oxigênio nos animais do Grupo 2 não estimulados e estimulados por bactérias - São Paulo - 2014

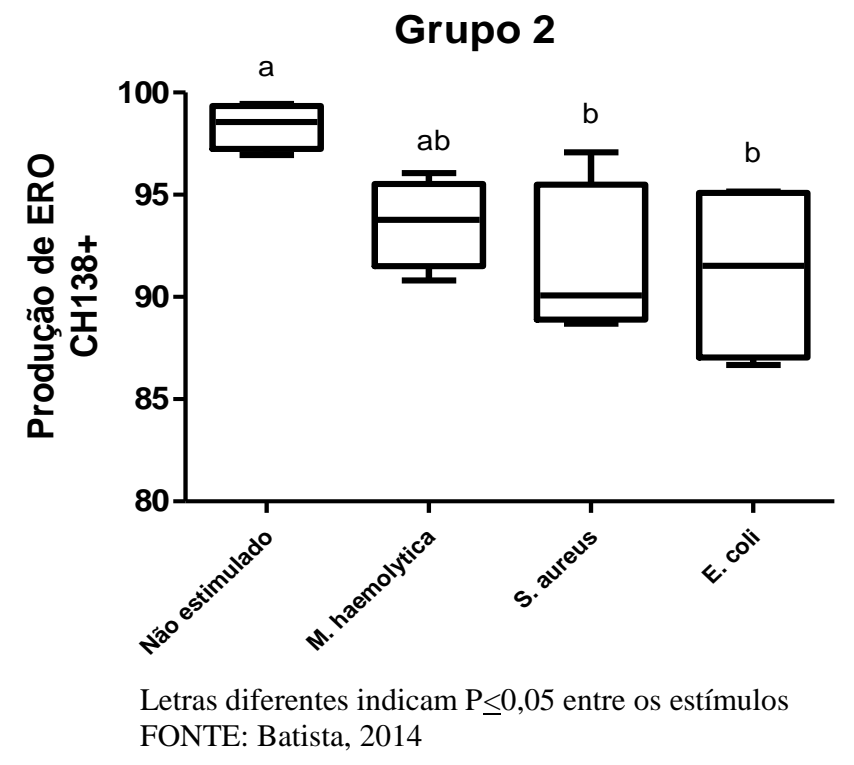


Nas tabelas 27 a 29 estão representados os valores medianos e intervalo de confiança das células $\mathrm{CD}_{14}^{+}$, que fagocitaram $M$. haemolytica, S. aureus e E. coli, respectivamente.

Tabela 27 - Valores medianos e dos intervalos de confiança das células CD14+ que fagocitaram Mannheimia haemolytica e intensidade de fluorescência em valores arbitrários no sangue de bezerros durante os quatro momentos da infecção experimental por Mannheimia haemolytica - São Paulo - 2014

\begin{tabular}{ccccc}
\hline \multirow{2}{*}{ Tempo } & \multicolumn{4}{c}{ M. haemolytica } \\
\cline { 2 - 5 } & G1 & G2 & Intensidade de Fluorescência \\
M1 & $40,95^{\mathrm{Ba}}$ & $45,65^{\mathrm{Ba}}$ & $\mathbf{G 1}$ & G2 \\
& $(31,27-46,99)$ & $(29,45-76,13)$ & $(3,72-43,84)$ & $(5,74-45,80)$ \\
M2 & $46,19^{\mathrm{ABa}}$ & $61,00^{\mathrm{ABa}}$ & $57,00^{\mathrm{Aa}}$ & $52,60^{\mathrm{Aa}}$ \\
& $(27,38-87,81)$ & $(34,12-93,44)$ & $(31,87-91,66)$ & $(18,44-112,56)$ \\
M3 & $96,95^{\mathrm{Aa}}$ & $93,65^{\mathrm{Aa}}$ & $54,25^{\mathrm{ABa}}$ & $51,05^{\mathrm{ABa}}$ \\
& $(73,88-106,29)$ & $(87,59-98,71)$ & $(34,88-67,65)$ & $(29,29-86,74)$ \\
M4 & $78,88^{\mathrm{ABa}}$ & $58,13^{\mathrm{ABa}}$ & $19,45^{\mathrm{Ba}}$ & $19,40^{\mathrm{Ba}}$ \\
& $(56,27-95,62)$ & $(44,15-78,66)$ & $(17,13-24,01)$ & $(10,99-42,08)$ \\
\hline P & 0,001 & 0,03 & 0,002 & 0,009 \\
\hline
\end{tabular}

M1: Antes da inoculação, M2: Momento das manifestações clínicas, M3: Um dia após o fim do tratamento, M4: Uma semana após o fim do tratamento

G1: norfloxacina associada a flunixina meglumina; G2: somente norfloxacina

Letras Maiúsculas diferentes indicam $\mathrm{P} \leq 0,05$ entre os momentos experimentais.

Letras Minúsculas diferentes indicam $\mathrm{P} \leq 0,05$ entre os grupos

Tabela 28 - Valores medianos e dos intervalos de confiança das células CD14 ${ }^{+}$que fagocitaram Staphylococcus aureus e intensidade de fluorescência em valores arbitrários no sangue de bezerros durante os quatro momentos da infecção experimental por Mannheimia haemolytica - São Paulo - 2014

\begin{tabular}{|c|c|c|c|c|}
\hline \multirow{3}{*}{ Tempo } & \multicolumn{4}{|c|}{ S. aureus } \\
\hline & \multicolumn{2}{|c|}{ Fagocitose (\%) } & \multicolumn{2}{|c|}{ Intensidade de Fluorescência } \\
\hline & G1 & G2 & G1 & G2 \\
\hline$M 1$ & $55,05^{\mathrm{ABa}}$ & $60,15^{\mathrm{ABa}}$ & $103,25^{\mathrm{Aa}}$ & $47,60^{\mathrm{Aa}}$ \\
\hline IVII & $(24,36-71,77)$ & $(31,69-85,43)$ & $(35,97-166,22)$ & $(-2,44-200,94)$ \\
\hline M2 & $\begin{array}{c}19,69^{\mathrm{Ba}} \\
(7,31-30,13)\end{array}$ & $\begin{array}{c}10,75^{\mathrm{Ba}} \\
(7,31-14,22)\end{array}$ & $\begin{array}{c}15,85^{\mathrm{Ba}} \\
(6,50-28,09)\end{array}$ & $\begin{array}{c}12,65^{\mathrm{Ba}} \\
(3,91-18,34)\end{array}$ \\
\hline M3 & $\begin{array}{c}72,95^{\text {Аа }} \\
(55,73-86,69)\end{array}$ & $\begin{array}{c}82,63^{\mathrm{Aa}} \\
(70,56-91,02)\end{array}$ & $\begin{array}{c}42,95^{\mathrm{ABa}} \\
(17,55-78,41)\end{array}$ & $\begin{array}{c}47,55^{\mathrm{ABa}} \\
(5,16-102,80)\end{array}$ \\
\hline M4 & $\begin{array}{c}78,25^{\mathrm{Aa}} \\
(57,81-92,14)\end{array}$ & $\begin{array}{c}78,55^{\text {Аa }} \\
(57,72-92,14)\end{array}$ & $\begin{array}{c}46,15^{\mathrm{ABa}} \\
(14,66-84,60)\end{array}$ & $\begin{array}{c}48,05^{\mathrm{ABa}} \\
(24,03-66,60)\end{array}$ \\
\hline $\mathbf{P}$ & 0,007 & 0,003 & 0,02 & 0,018 \\
\hline
\end{tabular}

M1: Antes da inoculação, M2: Momento das manifestações clínicas, M3: Um dia após o fim do tratamento, M4: Uma semana após o fim do tratamento

G1: norfloxacina associada a flunixina meglumina; G2: somente norfloxacina

Letras Maiúsculas diferentes indicam $\mathrm{P} \leq 0,05$ entre os momentos experimentais.

Letras Minúsculas diferentes indicam $\mathrm{P} \leq 0,05$ entre os grupos 
Tabela 29 - Valores medianos e dos intervalos de confiança das células CD14 ${ }^{+}$que fagocitaram Escherichia coli e intensidade de fluorescência em valores arbitrários no sangue de bezerros durante os quatro momentos da infecção experimental por Mannheimia haemolytica - São Paulo - 2014

\begin{tabular}{|c|c|c|c|c|}
\hline \multirow{3}{*}{$\begin{array}{l}\text { Tempo } \\
\text { Grupos }\end{array}$} & \multicolumn{4}{|c|}{ E.coli } \\
\hline & \multicolumn{2}{|c|}{ Fagocitose $(\%)$} & \multicolumn{2}{|c|}{ Intensidade de Fluorescência } \\
\hline & G1 & G2 & G1 & G2 \\
\hline M1 & $\begin{array}{c}70,70^{\mathrm{Aa}} \\
(57,08-85,01)\end{array}$ & $\begin{array}{c}73,45^{\text {Aa }} \\
(53,59-89,88)\end{array}$ & $\begin{array}{c}22,60^{\mathrm{ABa}} \\
(6,46-66,04)\end{array}$ & $\begin{array}{c}22,65^{\mathrm{ABa}} \\
(5,97-59,89)\end{array}$ \\
\hline M2 & $\begin{array}{c}2,18^{\mathrm{Ba}} \\
(-0,13-8,24)\end{array}$ & $\begin{array}{c}3,88^{\mathrm{Ba}} \\
(1,78-6,47)\end{array}$ & $\begin{array}{c}2,31^{\mathrm{Ba}} \\
(1,78-3,71)\end{array}$ & $\begin{array}{c}2,41^{\mathrm{Ba}} \\
(2,11-2,94)\end{array}$ \\
\hline M3 & $\begin{array}{c}83,59^{\mathrm{Aa}} \\
(74,56-92,80)\end{array}$ & $\begin{array}{c}83,70^{\text {Аа }} \\
(79,95-89,78)\end{array}$ & $\begin{array}{c}19,15^{\mathrm{ABa}} \\
(12,25-31,11)\end{array}$ & $\begin{array}{c}20,15^{\mathrm{ABa}} \\
(8,77-29,39)\end{array}$ \\
\hline M4 & $\begin{array}{c}78,74^{\mathrm{Aa}} \\
(74,87-81,63)\end{array}$ & $\begin{array}{c}83,00^{\mathrm{Aa}} \\
(73,02-89,48)\end{array}$ & $\begin{array}{c}118,50^{\mathrm{Aa}} \\
(90,42-183,22)\end{array}$ & $\begin{array}{c}122,00^{\mathrm{Aa}} \\
(98,92-151,41)\end{array}$ \\
\hline$P$ & 0,0006 & 0,01 & $<0,0001$ & $<0,0001$ \\
\hline
\end{tabular}

M1: Antes da inoculação, M2: Momento das manifestações clínicas, M3: Um dia após o fim do tratamento, M4: Uma semana após o fim do tratamento

G1: norfloxacina associada a flunixina meglumina; G2: somente norfloxacina

Letras Maiúsculas diferentes indicam $\mathrm{P} \leq 0,05$ entre os momentos experimentais.

Letras Minúsculas diferentes indicam $\mathrm{P} \leq 0,05$ entre os grupos

Observando os resultados da porcentagem de células $\mathrm{CD}_{1} 4^{+}$que fagocitaram $M$. haemolytica fica evidenciado que M3 foi maior que o M1. Em relação IMF foi evidenciado para ambos os grupos que M2 foi maior que M1 e M4. Considerando S. aureus, a porcentagem de células $\mathrm{CD} 14^{+}$que fagocitaram esta bactéria foi menor no M2 que M3 e M4; similarmente, a IMF da fagocitose desta bactéria, pelas células $\mathrm{CD}_{14}{ }^{+}$, foi menor no M2 que M1. Do mesmo modo, a porcentagem de células $\mathrm{CD}_{14}{ }^{+}$, que fagocitaram E. coli, foi menor no M2 que em todos os demais momentos, e sua IMF foi também menor em M2 que M4. O comportamento entre os grupos não foi alterado.

Nas tabelas 30 a 32 estão representados os valores medianos e intervalo de confiança dos granulócitos que fagocitaram a M. haemolytica, a $S$. aureus e a E. coli, respectivamente. 
Tabela 30 - Valores medianos e dos intervalos de confiança células $\mathrm{CH} 138^{+}$que fagocitaram Mannheimia haemolytica e intensidade de fluorescência em valores arbitrários no sangue de bezerros durante os quatro momentos da infecção experimental por Mannheimia haemolytica São Paulo - 2014

\begin{tabular}{ccccc}
\hline \multirow{2}{*}{ Tempo } & \multicolumn{4}{c}{ M. haemolytica } \\
\cline { 2 - 5 } Grupos & G1 & G2 & Intensidade de Fluorescência \\
M1 & $92,08^{\mathrm{Aa}}$ & $94,48^{\mathrm{Aa}}$ & $60,00^{\mathrm{ABa}}$ & G2 \\
& $(34,39-110,96)$ & $(33,60-112,45)$ & $(11,20-153,83)$ & $(37,85-155,62)$ \\
\multirow{2}{*}{ M2 } & $88,61^{\mathrm{Aa}}$ & $86,40^{\mathrm{Aa}}$ & $28,65^{\mathrm{Ba}}$ & $23,90^{\mathrm{Ba}}$ \\
& $(63,67-104,36)$ & $(59,56-99,17)$ & $(12,29-40,69)$ & $(10,70-32,89)$ \\
M3 & $98,35^{\mathrm{Aa}}$ & $98,00^{\mathrm{Aa}}$ & $573,00^{\mathrm{Aa}}$ & $524,00^{\mathrm{Aa}}$ \\
& $(95,97-99,99)$ & $(95,19-99,98)$ & $(363,20-812,13)$ & $(234,35-10006,3)$ \\
M4 & $99,53^{\mathrm{Aa}}$ & $99,59^{\mathrm{Aa}}$ & $391,50^{\mathrm{Aa}}$ & $536,50^{\mathrm{Aa}}$ \\
& $(95,73-100,73)$ & $(97,75-100,28)$ & $(138,14-1007,2)$ & $(168,93-1167,4)$ \\
\hline P & 0,21 & 0,13 & $<0,0001$ & $<0,0001$ \\
\hline
\end{tabular}

M1: Antes da inoculação, M2: Momento das manifestações clínicas, M3: Um dia após o fim do tratamento, M4: Uma semana após o fim do tratamento

G1: norfloxacina associada a flunixina meglumina; G2: somente norfloxacina

Letras Maiúsculas diferentes indicam $\mathrm{P} \leq 0,05$ entre os momentos experimentais.

Letras Minúsculas diferentes indicam $\mathrm{P} \leq 0,05$ entre os grupos

Tabela 31 - Valores medianos e dos intervalos de confiança de células $\mathrm{CH} 138^{+}$que fagocitaram Staphylococcus aureus e intensidade de fluorescência em valores arbitrários no sangue de bezerros durante os quatro momentos da infecção experimental por Mannheimia haemolytica - São Paulo 2014

\begin{tabular}{ccccc}
\hline \multirow{2}{*}{ Tempo } & \multicolumn{4}{c}{ S. aureus } \\
\cline { 2 - 5 } Grupos & G1 & G2 & Intensidade de Fluorescência \\
\cline { 2 - 5 } M1 & $61,00^{\mathrm{Aa}}$ & $44,49^{\mathrm{Aa}}$ & $63,35^{\mathrm{ABa}}$ & G2 \\
& $(27,74-75,59)$ & $(16,50-80,50)$ & $(32,74-87,83)$ & $\left(13,38-45^{\mathrm{Aa}}\right.$ \\
M2 & $57,09^{\mathrm{Aa}}$ & $52,55^{\mathrm{Aa}}$ & $42,40^{\mathrm{Ba}}$ & $52,05^{\mathrm{Aa}}$ \\
& $(36,31-81,59)$ & $(37,01-61,21)$ & $(15,57-75,53)$ & $(16,15-82,65)$ \\
M3 & $43,00^{\mathrm{Aa}}$ & $60,74^{\mathrm{Aa}}$ & $45,95^{\mathrm{Ba}}$ & $80,40^{\mathrm{Aa}}$ \\
& $(24,38-79,35)$ & $(41,14-81,50)$ & $(18,09-73,40)$ & $(24,40-110,00)$ \\
M4 & $38,44^{\mathrm{Aa}}$ & $39,07^{\mathrm{Aa}}$ & $107,40^{\mathrm{Aa}}$ & $70,50^{\mathrm{Aa}}$ \\
& $(23,40-51,22)$ & $(26,74-46,84)$ & $(47,80-158,47)$ & $(-4,38-260,26)$ \\
\hline & 0,31 & 0,06 & 0,0028 & 0,15 \\
\hline
\end{tabular}

M1: Antes da inoculação, M2: Momento das manifestações clínicas, M3: Um dia após o fim do tratamento, M4: Uma semana após o fim do tratamento

G1: norfloxacina associada a flunixina meglumina; G2: somente norfloxacina

Letras Maiúsculas diferentes indicam $\mathrm{P} \leq 0,05$ entre os momentos experimentais.

Letras Minúsculas diferentes indicam $\mathrm{P} \leq 0,05$ entre os grupos 
Tabela 32 - Valores medianos e dos intervalos de confiança de células $\mathrm{CH} 138^{+}$que fagocitaram Escherichia coli e intensidade de fluorescência em valores arbitrários no sangue de bezerros durante os quatro momentos da infecção experimental por Mannheimia haemolytica - São Paulo - 2014

\begin{tabular}{ccccc}
\hline \multirow{2}{*}{ Tempo } & \multicolumn{4}{c}{ E.coli } \\
\cline { 2 - 5 } Grupos & $\mathbf{G 1}$ & $\mathbf{G 2}$ & Gntensidade de Fluorescência \\
\cline { 2 - 5 } M1 & $14,54^{\mathrm{Ba}}$ & $9,11^{\mathrm{Ba}}$ & $36,15^{\mathrm{ABa}}$ & G2 \\
& $(8,76-18,30)$ & $(4,30-20,40)$ & $(12,87-46,19)$ & $(5,51-34,01)$ \\
\multirow{2}{*}{ M2 } & $41,10^{\mathrm{Aa}}$ & $43,75^{\mathrm{Aa}}$ & $30,50^{\mathrm{ABa}}$ & $25,55^{\mathrm{ABa}}$ \\
& $(23,43-61,70)$ & $(29,84-58,65)$ & $(16,63-39,67)$ & $(11,71-44,65)$ \\
\multirow{2}{*}{ M3 } & $41,83^{\mathrm{Aa}}$ & $43,10^{\mathrm{Aa}}$ & $11,30^{\mathrm{Ba}}$ & $18,30^{\mathrm{ABa}}$ \\
& $(22,97-78,25)$ & $(19,25-78,65)$ & $(4,37-22,76)$ & $(11,77-23,76)$ \\
M4 & $30,10^{\mathrm{ABa}}$ & $27,02^{\mathrm{ABa}}$ & $75,05^{\mathrm{Aa}}$ & $62,35^{\mathrm{Aa}}$ \\
& $(12,57-47,53)$ & $(11,55-45,83)$ & $(17,73-176,90)$ & $(48,12-96,27)$ \\
\hline P & 0,007 & 0,0002 & 0,0006 & 0,02 \\
\hline
\end{tabular}

M1: Antes da inoculação, M2: Momento das manifestações clínicas, M3: Um dia após o fim do tratamento, M4: Uma semana após o fim do tratamento

G1: norfloxacina associada a flunixina meglumina; G2: somente norfloxacina

Letras Maiúsculas diferentes indicam $\mathrm{P} \leq 0,05$ entre os momentos experimentais.

Letras Minúsculas diferentes indicam $\mathrm{P} \leq 0,05$ entre os grupos

Observando os resultados da IMF da fagocitose de $M$. haemolytica por granulócitos fica evidenciado que M2 foi menor que o M3 e M4, em ambos os grupos. Considerando $S$. aureus, a IMF da fagocitose desta bactéria pelos granulócitos foi maior no M4 que M2 e M3, no G1. Do mesmo modo, a porcentagem de granulócitos que fagocitaram E. coli foi menor no M1 que M2 e M3, e sua IMF foi maior no M4 que M1 e M3 nos G1 e G2, respectivamente. O comportamento entre os grupos não foi alterado.

Quando comparadas as porcentagens de fagocitose entre as diferentes bactérias utilizadas para a prova podemos observar que no grupo G1 ocorreu maior fagocitose de $M$. haemolytica em relação à fagocitose de $S$. aureus e E. coli $(\mathrm{P}=0,0007)$ (Gráfico 5). O mesmo comportamento foi observado no grupo G2 (P=0,0003) (Gráfico 6). 
Gráfico 5 - Box Plot das médias e dos erros padrão da porcentagem de granulócitos do sangue que fagocitaram as distintas bactérias dos animais do Grupo 1 - São Paulo - 2014

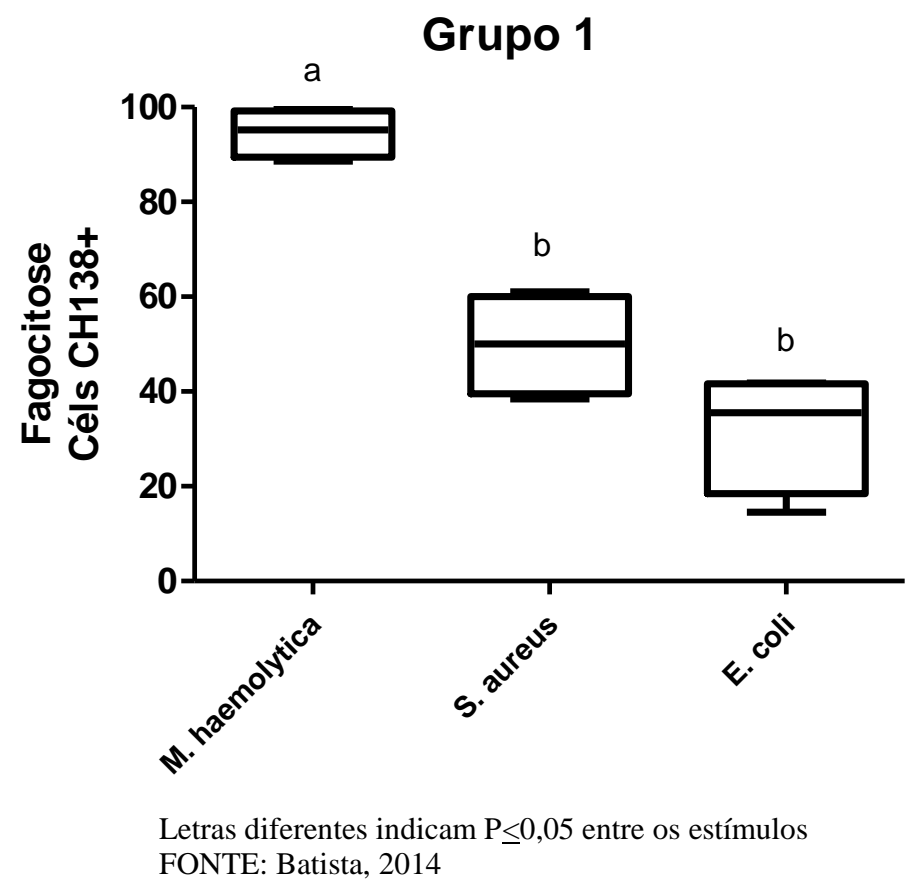

Gráfico 6 - Box Plot das médias e dos erros padrão da porcentagem de granulócitos do sangue que fagocitaram as distintas bactérias dos animais do Grupo 2 - São Paulo - 2014

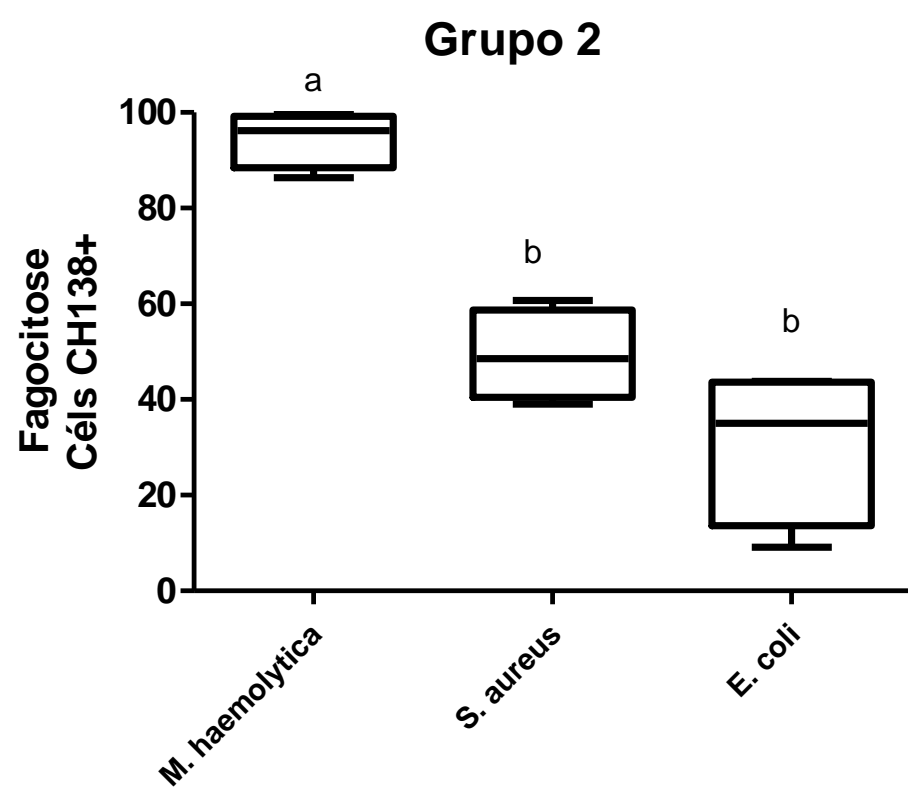

Letras diferentes indicam $\mathrm{P} \leq 0,05$ entre os estímulos FONTE: Batista, 2014 


\subsubsection{Viabilidade dos fagócitos do sangue}

Na tabela 33 estão representados os valores das médias e dos erros padrão das células $\mathrm{CD}_{14}{ }^{+}$do sangue periférico em apoptose, necrose, apoptose e/ou necrose e viáveis.

Tabela 33 - Valores percentuais das médias e dos erros padrão das células CD14 em apoptose, necrose, apoptose e/ou necrose e viáveis no sangue de bezerros durante os quatro momentos da infecção experimental por Mannheimia haemolytica - São Paulo - 2014

\begin{tabular}{|c|c|c|c|c|c|c|c|c|}
\hline Tempo & \multicolumn{2}{|c|}{ Anexina $\mathrm{V}^{+} / \mathrm{PI}^{-}(\%)$} & \multicolumn{2}{|c|}{ Anexina $\mathrm{V}-/ \mathrm{PI}^{+}(\%)$} & \multicolumn{2}{|c|}{ Anexina $\mathrm{V}^{+} / \mathrm{PI}^{+}(\%)$} & \multicolumn{2}{|c|}{ Anexina V//PI (\%) } \\
\hline & G1 & G2 & G1 & G2 & G1 & G2 & G1 & G2 \\
\hline M1 & $\begin{array}{c}1,52^{\mathrm{Aa}} \\
( \pm 0,373)\end{array}$ & $\begin{array}{c}2,14^{\mathrm{Aa}} \\
( \pm 1,382)\end{array}$ & $\begin{array}{c}6,84^{\mathrm{Ba}} \\
( \pm 2,692)\end{array}$ & $\begin{array}{c}8,58^{\mathrm{Ba}} \\
( \pm 2,983)\end{array}$ & $\begin{array}{c}4,88^{\mathrm{Aa}} \\
( \pm 1,961)\end{array}$ & $\begin{array}{c}2,16^{\mathrm{Ba}} \\
( \pm 1,233)\end{array}$ & $\begin{array}{c}86,75^{\text {Аa }} \\
( \pm 3,227)\end{array}$ & $\begin{array}{c}87,00^{\mathrm{Aa}} \\
( \pm 4,041)\end{array}$ \\
\hline M2 & $\begin{array}{c}2,31^{\mathrm{Aa}} \\
( \pm 0,961)\end{array}$ & $\begin{array}{c}3,91^{\mathrm{Aa}} \\
( \pm 1,166)\end{array}$ & $\begin{array}{c}34,28^{\mathrm{Aa}} \\
( \pm 3,845)\end{array}$ & $\begin{array}{c}33,52^{\mathrm{Aa}} \\
( \pm 4,520)\end{array}$ & $\begin{array}{c}7,68^{\mathrm{Aa}} \\
( \pm 1,616)\end{array}$ & $\begin{array}{c}8,89^{\mathrm{Aa}} \\
( \pm 2,426)\end{array}$ & $\begin{array}{c}55,72^{\mathrm{Ba}} \\
( \pm 3,608)\end{array}$ & $\begin{array}{c}53,68^{\mathrm{Ba}} \\
( \pm 2,080)\end{array}$ \\
\hline M3 & $\begin{array}{c}1,45^{\mathrm{Aa}} \\
( \pm 0,418)\end{array}$ & $\begin{array}{c}1,88^{\mathrm{Aa}} \\
( \pm 0,681)\end{array}$ & $\begin{array}{c}6,95^{\mathrm{Ba}} \\
( \pm 2,441)\end{array}$ & $\begin{array}{c}4,27^{\mathrm{Ba}} \\
( \pm 0,840)\end{array}$ & $\begin{array}{c}2,40^{\mathrm{Aa}} \\
( \pm 0,569)\end{array}$ & $\begin{array}{c}1,04^{\mathrm{Ba}} \\
( \pm 0,337)\end{array}$ & $\begin{array}{r}89,18^{\text {Aa }} \\
( \pm 2,453)\end{array}$ & $\begin{array}{r}92,82^{\mathrm{Aa}} \\
( \pm 1,095)\end{array}$ \\
\hline M4 & $\begin{array}{c}4,14^{\mathrm{Ba}} \\
( \pm 1,338)\end{array}$ & $\begin{array}{c}3,13^{\mathrm{Aa}} \\
( \pm 0,668)\end{array}$ & $\begin{array}{c}11,51^{\mathrm{Ba}} \\
( \pm 5,436)\end{array}$ & $\begin{array}{c}10,07^{\mathrm{Ba}} \\
( \pm 2,841)\end{array}$ & $\begin{array}{c}6,86^{\mathrm{Aa}} \\
( \pm 2,424)\end{array}$ & $\begin{array}{c}2,54^{\mathrm{Ba}} \\
( \pm 0,681)\end{array}$ & $\begin{array}{l}84,28^{\mathrm{Aa}} \\
( \pm 3,225)\end{array}$ & $\begin{array}{c}84,28^{\mathrm{Aa}} \\
( \pm 3,225)\end{array}$ \\
\hline$P$ & 0,04 & 0,47 & 0,0002 & $<0,0001$ & 0,24 & 0,01 & $<0,0001$ & $<0,0001$ \\
\hline
\end{tabular}

M1: Antes da inoculação, M2: Momento das manifestações clínicas, M3: Um dia após o fim do tratamento, M4: Uma semana após o fim do tratamento

G1: norfloxacina associada a flunixina meglumina; G2: somente norfloxacina

Letras Maiúsculas diferentes indicam $\mathrm{P} \leq 0,05$ entre os momentos experimentais.

Letras Minúsculas diferentes indicam $\mathrm{P} \leq 0,05$ entre os grupos

Anexina $\mathrm{V}^{+} / \mathrm{PI}$ : Células em apoptose; Anexina $\mathrm{V}^{-} / \mathrm{PI}^{+}$: Células em necrose; Anexina $\mathrm{V}^{+} / \mathrm{PI}^{+}$: Células em apoptose e/ou necrose; Anexina $\mathrm{V}^{-} / \mathrm{PI}^{-}$: Células viáveis

Os resultados das células mononucleares $\mathrm{CD} 14^{+}$do sangue demonstraram que no G1 houve aumento da porcentagem de células em apoptose no M4, em relação aos demais momentos, o que não foi observado no G2. Considerando os resultados obtidos de células $\mathrm{CD}_{1} 4^{+}$em necrose, fica evidente o aumento do fenômeno no momento $\mathrm{M} 2$, em relação aos demais momentos, para ambos os grupos. Houve aumento da porcentagem de células CD14 ${ }^{+}$ do sangue em apoptose tardia ou necrose secundária no M2 do G2 comparando aos demais momentos. Inversamente, a porcentagem de células $\mathrm{CD}_{14}{ }^{+}$viáveis diminuiu no $\mathrm{M} 2$, em relação aos demais momentos, para ambos os grupos.

$\mathrm{Na}$ tabela 34 estão dispostos os valores médios e dos erros padrão das células $\mathrm{CH} 138^{+}$no sangue periférico em apoptose, necrose, apoptose e/ou necrose e viáveis. 
Tabela 34 - Valores percentuais das médias e dos erros padrão das células $\mathrm{CH} 138^{+}$em apoptose, necrose, apoptose e/ou necrose e viáveis no sangue de bezerros durante os quatro momentos da infecção experimental por Mannheimia haemolytica - São Paulo - 2014

\begin{tabular}{|c|c|c|c|c|c|c|c|c|}
\hline Tempo & \multicolumn{2}{|c|}{ Anexina $\mathrm{V}^{+} / \mathrm{PI}^{-}(\%)$} & \multicolumn{2}{|c|}{ Anexina $\mathrm{V}^{-} / \mathrm{PI}^{+}(\%)$} & \multicolumn{2}{|c|}{ Anexina $\mathrm{V}^{+} / \mathrm{PI}^{+}(\%)$} & \multicolumn{2}{|c|}{ Anexina $\mathrm{V}^{-} / \mathrm{PI}^{-}(\%)$} \\
\hline & G1 & G2 & G1 & G2 & G1 & G2 & G1 & G2 \\
\hline M1 & $\begin{array}{c}1,16^{\mathrm{Aa}} \\
(0,393)\end{array}$ & $\begin{array}{c}1,16^{\mathrm{Aa}} \\
(0.709)\end{array}$ & $\begin{array}{c}5,51^{\mathrm{Ba}} \\
(1,278)\end{array}$ & $\begin{array}{l}4,57^{\mathrm{Ba}} \\
(1,110)\end{array}$ & $\begin{array}{l}2,24^{\mathrm{ABa}} \\
(1,266)\end{array}$ & $\begin{array}{c}0,55^{\mathrm{Aa}} \\
(0,136)\end{array}$ & $\begin{array}{l}91,10^{\mathrm{Aa}} \\
(2,721)\end{array}$ & $\begin{array}{l}93,68^{\mathrm{Aa}} \\
(1,219)\end{array}$ \\
\hline M2 & $\begin{array}{c}2,56^{\mathrm{Aa}} \\
(0,907)\end{array}$ & $\begin{array}{c}4,53^{\mathrm{Aa}} \\
(3,129)\end{array}$ & $\begin{array}{c}40,9^{\mathrm{Aa}} \\
(5,498)\end{array}$ & $\begin{array}{c}37,42^{\text {Aa }} \\
(10,467)\end{array}$ & $\begin{array}{c}4,75^{\text {Aa }} \\
(1,562)\end{array}$ & $\begin{array}{c}1,81^{\mathrm{Aa}} \\
(0,695)\end{array}$ & $\begin{array}{l}51,80^{\mathrm{Ba}} \\
(4,193)\end{array}$ & $\begin{array}{l}56,27^{\mathrm{Ba}} \\
(7,554)\end{array}$ \\
\hline M3 & $\begin{array}{c}1,52^{\mathrm{Aa}} \\
(0,417)\end{array}$ & $\begin{array}{c}0,52^{\mathrm{Ab}} \\
(0,171)\end{array}$ & $\begin{array}{c}7,28^{\mathrm{Ba}} \\
(2,976)\end{array}$ & $\begin{array}{r}6,69^{\mathrm{Ba}} \\
(1,327)\end{array}$ & $\begin{array}{c}1,01^{\mathrm{ABa}} \\
(0,258)\end{array}$ & $\begin{array}{c}1,08^{\mathrm{Aa}} \\
(0,417)\end{array}$ & $\begin{array}{l}90,20^{\mathrm{Aa}} \\
(3,389)\end{array}$ & $\begin{array}{l}91,73^{\mathrm{Aa}} \\
(1,379)\end{array}$ \\
\hline M4 & $\begin{array}{c}0,78^{\mathrm{Aa}} \\
(0,405)\end{array}$ & $\begin{array}{c}0,99^{\mathrm{Aa}} \\
(0,184)\end{array}$ & $\begin{array}{c}4,39^{\mathrm{Ba}} \\
(0,566)\end{array}$ & $\begin{array}{c}4,68^{\mathrm{Ba}} \\
(0,908)\end{array}$ & $\begin{array}{c}0,62^{\mathrm{Ba}} \\
(0,164)\end{array}$ & $\begin{array}{c}0,83^{\mathrm{Aa}} \\
(0,212)\end{array}$ & $\begin{array}{l}94,20^{\mathrm{Aa}} \\
(1,020)\end{array}$ & $\begin{array}{l}93,48^{\mathrm{Aa}} \\
(0,967)\end{array}$ \\
\hline P & 0,18 & 0,30 & $<0,0001$ & 0,0009 & 0,04 & 0,14 & $<0,0001$ & $<0.0001$ \\
\hline
\end{tabular}

M1: Antes da inoculação, M2: Momento das manifestações clínicas, M3: Um dia após o fim do tratamento, M4: Uma semana após o fim do tratamento

G1: norfloxacina associada a flunixina meglumina; $\mathrm{G} 2$ : somente norfloxacina

Letras Maiúsculas diferentes indicam $\mathrm{P} \leq 0,05$ entre os momentos experimentais.

Letras Minúsculas diferentes indicam $\mathrm{P} \leq 0,05$ entre os grupos

Anexina $\mathrm{V}^{+} / \mathrm{PI}^{-}$: Células em apoptose; Anexina $\mathrm{V}^{-} / \mathrm{PI}^{+}$: Células em necrose; Anexina $\mathrm{V}^{+} / \mathrm{PI}^{+}$: Células em apoptose e/ou necrose; Anexina V-/PI: Células viáveis

Os resultados dos granulócitos em apoptose do sangue periférico demonstraram que no $\mathrm{M} 3$ o $\mathrm{G} 1$ foi maior que $\mathrm{G} 2(\mathrm{P}=0,03)$. Considerando os resultados obtidos dos granulócitos em necrose, fica evidente o aumento do fenômeno no momento $\mathrm{M} 2$, em relação aos demais momentos, para ambos os grupos. Houve aumento da porcentagem de granulócitos sanguíneos em apoptose tardia ou necrose secundária no M2 do G1, em relação a M4. Inversamente, a porcentagem de granulócitos viáveis diminuiu no M2 em relação a M1 e M4 no $\mathrm{G} 1$ e aos demais momentos, no G2.

\subsubsection{Expressão gênica de citocinas}

A expressão do mRNA para as citocinas IL-1 $\beta$, IL-8 e TNF- $\alpha$ de leucócitos sanguíneos e de células broncoalveolares estão contidos respectivamente nas tabelas 35 e 36 . Os valores foram calculados baseados na proporção entre o ratio de cada gene alvo e o gene referência (GAPDH), expressos corrigindo a fórmula pela eficiência. 
Tabela 35 - Expressão das citocinas (medianas e intervalos de confiança) nas células do sangue periférico (razão entre mRNA citocinas- interleucina-1 $\beta$, interleucina- 8 e fator de necrose tumoral $\alpha$ em relação ao mRNA do gene referência - GAPDH) dos bezerros durante os quatro momentos da infecção experimental por Mannheimia haemolytica - São Paulo - 2014

\begin{tabular}{|c|c|c|c|c|c|c|}
\hline \multirow[t]{2}{*}{ Tempo } & \multicolumn{2}{|c|}{ IL-1 $\beta$} & \multicolumn{2}{|c|}{ IL-8 } & \multicolumn{2}{|c|}{ TNF- $\alpha$} \\
\hline & G1 & G2 & G1 & G2 & G1 & G2 \\
\hline M1 & $\begin{array}{c}0,590^{\mathrm{A}} \\
(-1,312-2,493)\end{array}$ & - & - & - & $\begin{array}{c}0,046^{\mathrm{A}} \\
(-0,299-0,392)\end{array}$ & - \\
\hline M2 & $\begin{array}{c}3,012^{\mathrm{Aa}} \\
(-0,494-6,994)\end{array}$ & $\begin{array}{c}2,364^{\mathrm{Aa}} \\
(0,850-3,791)\end{array}$ & - & - & 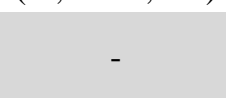 & $\begin{array}{c}0,285^{\mathrm{A}} \\
(-0,759-1,657)\end{array}$ \\
\hline M3 & $\begin{array}{c}1,942^{\mathrm{Aa}} \\
(-0,267-5,196)\end{array}$ & $\begin{array}{c}2,333^{\mathrm{Aa}} \\
(1,251-3,259)\end{array}$ & - & - & $\begin{array}{c}0,232^{\mathrm{Aa}} \\
(-0305-0,770)\end{array}$ & $\begin{array}{c}0,964^{\mathrm{Aa}} \\
(-9,539-11,467)\end{array}$ \\
\hline M4 & $\begin{array}{c}1,070^{\mathrm{Aa}} \\
(0,100-2,675)\end{array}$ & $\begin{array}{c}0,2633^{\text {Aa }} \\
(-2,445-2,972)\end{array}$ & - & - & $\begin{array}{c}0,243^{\text {Aa }} \\
(0,243-0,243)\end{array}$ & $\begin{array}{c}0,100^{\mathrm{Aa}} \\
(-1,128-1,330)\end{array}$ \\
\hline P & 0,18 & 0,09 & - & - & 0,33 & 0,25 \\
\hline
\end{tabular}

M1: Antes da inoculação, M2: Momento das manifestações clínicas, M3: Um dia após o fim do tratamento, M4: Uma semana após o fim do tratamento

G1: norfloxacina associada a flunixina meglumina; G2: somente norfloxacina

Letras Maiúsculas diferentes indicam $\mathrm{P} \leq 0,05$ entre os momentos experimentais.

Letras Minúsculas diferentes indicam $\mathrm{P} \leq 0,05$ entre os grupos

A análise das citocinas IL-1 $\beta$, presentes no sangue, não apresentou leitura satisfatória no M1 do G2 (16,67 \%), não sendo possível realizar a análise estatística deste momento. Entre os demais momentos, não houve diferença na expressão de IL-1 $\beta$ nos dois grupos experimentais. Não houve diferença entre os grupos em nenhum dos momentos.

O mesmo ocorreu com a expressão de TNF- $\alpha$ no M1 do G2 (16,67 \%) e no M2 do G1 (33,33\%), que não apresentou leitura satisfatória; entre os demais momentos não houve diferença estatística entre os grupos.

A expressão de mRNA para IL-8 no sangue não pode ser analisada, pois uma pequena quantidade de amostras apenas apresentou leitura (18,75\%), não sendo possível realizar a análise estatística. Isso pode ter ocorrido pela baixa expressão do mRNA da citocina nas células do sangue. 
Tabela 36 - Expressão das citocinas (Medianas e intervalos de confiança) das células do lavado broncoalveolar (razão entre mRNA citocinas- interleucina-1 $\beta$, interleucina- 8 e fator de necrose tumoral- $\alpha$ em relação ao mRNA do gene referência- GAPDH) dos bezerros durante os quatro momentos da infecção experimental por Mannheimia haemolytica - São Paulo - 2014

\begin{tabular}{ccccccc}
\hline Tempo & \multicolumn{2}{c}{ IL-1 $\beta$} & \multicolumn{2}{c}{ IL-8 } & \multicolumn{2}{c}{ TNF- $\alpha$} \\
\hline \multirow{2}{*}{ M1 } & G1 & G2 & G1 & G2 & G1 & G2 \\
& $1,100^{\mathrm{Aa}}$ & $1,037^{\mathrm{Aa}}$ & $0,438^{\mathrm{Aa}}$ & $0,149^{\mathrm{Aa}}$ & $0,056^{\mathrm{Aa}}$ & $0,019^{\mathrm{Aa}}$ \\
\multirow{2}{*}{ M2 } & $(0,498-1,908)$ & $(0,387-2,444)$ & $(-0,538-1,393)$ & $(0,149-0,149)$ & $(-0,015-0,140)$ & $(-0,211-0,250)$ \\
& $1,195^{\mathrm{Aa}}$ & $4,141^{\mathrm{Aa}}$ & $1,570^{\mathrm{Aa}}$ & $1,748^{\mathrm{Aa}}$ & $0,097^{\mathrm{Aa}}$ & $0,257^{\mathrm{Aa}}$ \\
\multirow{2}{*}{ M3 } & $(-0,668-4,834)$ & $(0,241-6,477)$ & $(0,186-2,954)$ & $(-0,463-3,960)$ & $(-0,474-0,893)$ & $(-0,648-1,390)$ \\
& $2,147^{\mathrm{Aa}}$ & $2,203^{\mathrm{Aa}}$ & $0,270^{\mathrm{Aa}}$ & $0,692^{\mathrm{Aa}}$ & $0,191^{\mathrm{Aa}}$ & $0,496^{\mathrm{Aa}}$ \\
\multirow{2}{*}{ M4 } & $(0,195-7,026)$ & $(0,696-6,437)$ & $(-1,494-2,034)$ & $(0,692-0,692)$ & $(-3,332-5,660)$ & $(-0,746-2,340)$ \\
& $2,494^{\mathrm{Aa}}$ & $0,278^{\mathrm{Aa}}$ & $0,011^{\mathrm{Ab}}$ & $1,237^{\mathrm{Aa}}$ & $0,645^{\mathrm{Aa}}$ & $0,194^{\mathrm{Aa}}$ \\
P & $(0,827-3,564)$ & $(-0,878-4,377)$ & $(-0,002-0,030)$ & $(-3,382-6,986)$ & $(0,031-1,510)$ & $(-0,448-1,611)$ \\
\hline
\end{tabular}

M1: Antes da inoculação, M2: Momento das manifestações clínicas, M3: Um dia após o fim do tratamento, M4: Uma semana após o fim do tratamento

G1: norfloxacina associada a flunixina meglumina; G2: somente norfloxacina

Letras Maiúsculas diferentes indicam $\mathrm{P} \leq 0,05$ entre os momentos experimentais.

Letras Minúsculas diferentes indicam $\mathrm{P} \leq 0,05$ entre os grupos

Ao contrário do que ocorreu no sangue dos animais do estudo, a expressão das citocinas foi satisfatória no lavado broncoalveolar. Porém, a análise das citocinas presentes no LBA de bezerros não apresentou diferença entre os momentos, para as três citocinas analisadas.

Observando a produção de IL-8, notou-se numericamente a menor expressão no G1 no M4 em relação ao G2, o que sugere que o tratamento pode ter alguma influência na expressão dessa interleucina nas células do LBA. Para as demais citocinas não houve diferença entre os grupos.

\subsection{DESAFIO FUNCIONAL IN VITRO}

Nas tabelas e gráficos a seguir estão dispostos os resultados da avaliação do efeito in vitro do antimicrobiano norfloxacina sobre a função dos fagócitos do LBA e do sangue de bezerros sadios. 


\subsubsection{Avaliação nas células do LBA}

Na tabela 37 estão representados os valores da produção e intensidade de fluorescência de ERO basal e estimulados por M. haemolytica, S. aureus e E. coli das células $\mathrm{CD}_{14}^{+}$do LBA.

Tabela 37 - Efeito in vitro da norfloxacina sobre a porcentagem de células CD14 ${ }^{+}$que produziram espécies reativas de oxigênio e intensidade de fluorescência (IMF) em valores arbitrários basal e estimulados por Mannheimia haemolytica, Staphylococcus aureus e Escherichia coli no lavado broncoalveolar de bezerros sadios - São Paulo - 2014

\begin{tabular}{|c|c|c|c|c|c|c|c|c|}
\hline \multirow[t]{2}{*}{ Grupos } & \multicolumn{2}{|c|}{ Não estimulado } & \multicolumn{2}{|c|}{$\begin{array}{c}\text { Estimulado por } M \text {. } \\
\text { haemolytica }\end{array}$} & \multicolumn{2}{|c|}{$\begin{array}{c}\text { Estimulado por } S \text {. } \\
\text { aureus }\end{array}$} & \multicolumn{2}{|c|}{$\begin{array}{l}\text { Estimulado por } \\
\text { E.coli }\end{array}$} \\
\hline & $(\%)$ & IMF & $(\%)$ & IMF & $(\%)$ & IMF & $(\%)$ & IMF \\
\hline $\begin{array}{c}\text { Com } \\
\text { antimicrob } \\
\text { iano }\end{array}$ & $\begin{array}{r}49,52^{\mathrm{A}} \\
( \pm 6,54)\end{array}$ & $\begin{array}{r}71,73^{\mathrm{A}} \\
( \pm 22,73)\end{array}$ & $\begin{array}{r}64,86^{\mathrm{A}} \\
( \pm 9,49)\end{array}$ & $\begin{array}{r}87,30^{\mathrm{A}} \\
( \pm 38,57)\end{array}$ & $\begin{array}{r}24,48^{\mathrm{B}} \\
( \pm 3,27)\end{array}$ & $\begin{array}{l}57,57^{\mathrm{A}} \\
( \pm 1,36)\end{array}$ & $\begin{array}{l}25,14^{\mathrm{A}} \\
( \pm 3,53)\end{array}$ & $\begin{array}{r}88,09^{\mathrm{A}} \\
( \pm 16,6)\end{array}$ \\
\hline $\begin{array}{c}\text { Sem } \\
\text { antimicrob } \\
\text { iano }\end{array}$ & $\begin{array}{r}40,07^{\mathrm{A}} \\
( \pm 5,2)\end{array}$ & $\begin{array}{c}72,81^{\mathrm{A}} \\
( \pm 17,95)\end{array}$ & $\begin{array}{l}75,52^{\mathrm{A}} \\
( \pm 3,95)\end{array}$ & $\begin{array}{c}67,30^{\mathrm{A}} \\
( \pm 36,81)\end{array}$ & $\begin{array}{c}60,64^{\mathrm{A}} \\
( \pm 10,87)\end{array}$ & $\begin{array}{c}75,28^{\mathrm{A}} \\
( \pm 10,39)\end{array}$ & $\begin{array}{l}37,82^{\mathrm{A}} \\
( \pm 9,58)\end{array}$ & $\begin{array}{l}24,63^{\mathrm{B}} \\
( \pm 6,42)\end{array}$ \\
\hline $\mathbf{P}$ & 0,26 & 0,97 & 0,28 & 0,87 & 0,008 & 0,13 & 0,26 & 0,001 \\
\hline
\end{tabular}

Com antimicrobiano $=$ amostras que receberam norfloxacina in vitro

Sem antimicrobiano $=$ amostras que não receberam norfloxacina in vitro

Letras Maiúsculas diferentes indicam $\mathrm{P} \leq 0,05$ entre os grupos experimentais.

Quando a produção de ERO por células CD14+ do LBA foi estimulada pela presença de bactérias, observou-se diferença quando estimulado por $S$. aureus, sendo que as amostras tratadas com antimicrobiano in vitro apresentaram menor porcentagem de células produzindo $\mathrm{ERO}$, em relação às amostras que não receberam antimicrobiano. Isto não ocorreu com as amostras estimuladas por $E$. coli, que não apresentaram diferença na porcentagem, mas a IMF da produção de ERO no grupo que recebeu o antimicrobiano in vitro foi maior do que a intensidade do grupo sem antimicrobiano.

Na tabela 38 estão representados os valores das médias e dos erros padrão das células $\mathrm{CD}_{14}^{+}$que fagocitaram M. haemolytica, S. aureus e E. coli e que foram desafiadas in vitro com antimicrobiano norfloxacina. 
Tabela 38 - Efeito in vitro da norfloxacina sobre a porcentagem de células $\mathrm{CD}_{14}{ }^{+}$que fagocitaram Mannheimia haemolytica, Staphylococcus aureus e Escherichia coli no LBA de bezerros sadios - São Paulo - 2014

\begin{tabular}{|c|c|c|c|c|c|c|}
\hline \multirow[b]{2}{*}{ Grupos } & \multicolumn{2}{|c|}{ M. haemolytica } & \multicolumn{2}{|c|}{ S. aureus } & \multicolumn{2}{|c|}{ E.coli } \\
\hline & $\begin{array}{c}\text { Fagocitose } \\
(\%)\end{array}$ & $\begin{array}{c}\text { Intensidade } \\
\text { de } \\
\text { Fluorescência }\end{array}$ & $\begin{array}{c}\text { Fagocitose } \\
(\%)\end{array}$ & $\begin{array}{c}\text { Intensidade } \\
\text { de } \\
\text { Fluorescência }\end{array}$ & $\begin{array}{c}\text { Fagocitose } \\
(\%)\end{array}$ & $\begin{array}{c}\text { Intensidade } \\
\text { de } \\
\text { Fluorescência }\end{array}$ \\
\hline Com & $59,57^{\mathrm{A}}$ & $19,49^{\mathrm{A}}$ & $63,90^{\mathrm{A}}$ & $23,92^{\mathrm{A}}$ & $49,87^{\mathrm{A}}$ & $146,43^{\mathrm{A}}$ \\
\hline antimicrobiano & $( \pm 7,44)$ & $( \pm 3,74)$ & $( \pm 0,56)$ & $( \pm 6,32)$ & $( \pm 3,73)$ & $( \pm 22,38)$ \\
\hline $\begin{array}{c}\text { Sem } \\
\text { antimicrobiano }\end{array}$ & $\begin{array}{l}35,39^{\mathrm{B}} \\
( \pm 5,96)\end{array}$ & $\begin{array}{c}6,53^{\mathrm{B}} \\
( \pm 1,57)\end{array}$ & $\begin{array}{c}48,63^{\mathrm{A}} \\
( \pm 11,49)\end{array}$ & $\begin{array}{l}20,21^{\mathrm{A}} \\
( \pm 5,12)\end{array}$ & $\begin{array}{c}52,46^{\mathrm{A}} \\
( \pm 10,54)\end{array}$ & $\begin{array}{l}64,60^{\mathrm{B}} \\
( \pm 23,6)\end{array}$ \\
\hline $\mathrm{P}$ & 0,01 & 0,003 & 0,34 & 0,65 & 0,88 & 0,02 \\
\hline
\end{tabular}

Com antimicrobiano $=$ amostras que receberam norfloxacina in vitro

Sem antimicrobiano $=$ amostras que não receberam norfloxacina in vitro

Letras Maiúsculas diferentes indicam $\mathrm{P} \leq 0,05$ entre os grupos experimentais.

No ensaio realizado para as provas de fagocitose com $M$. haemolytica, foi observada maior porcentagem de células $\mathrm{CD} 14^{+}$do LBA que fagocitaram e IMF da fagocitose desta bactéria no grupo tratado com antimicrobiano, quando comparado com o grupo controle. Além disso observou-se maior IMF da fagocitose de E. coli do grupo que recebeu o antimicrobiano in vitro.

\subsubsection{Avaliação nas células do sangue}

Na tabela 39 estão representados os valores da produção e IMF de ERO basal e estimulados por M. haemolytica, S. aureus e E. coli, das células $\mathrm{CD}_{14}^{+}$do sangue. 
Tabela 39 - Efeito in vitro da Norfloxacina sobre a porcentagem de células CD14 ${ }^{+}$que produziram espécies reativas de oxigênio e intensidade de fluorescência (IMF) em valores arbitrários basal e estimulados por Mannheimia haemolytica, Staphylococcus aureus e Escherichia coli no sangue de bezerros sadios - São Paulo - 2014

\begin{tabular}{|c|c|c|c|c|c|c|c|c|}
\hline \multirow[t]{2}{*}{ Grupos } & \multicolumn{2}{|c|}{ Não estimulado } & \multicolumn{2}{|c|}{$\begin{array}{c}\text { Estimulado por } M \text {. } \\
\text { haemolytica }\end{array}$} & \multicolumn{2}{|c|}{$\begin{array}{c}\text { Estimulado por } S \text {. } \\
\text { aureus }\end{array}$} & \multicolumn{2}{|c|}{$\begin{array}{l}\text { Estimulado por } \\
\text { E.coli }\end{array}$} \\
\hline & $(\%)$ & IMF & $(\%)$ & IMF & $(\%)$ & IMF & $(\%)$ & IMF \\
\hline $\begin{array}{c}\text { Com } \\
\text { antimicrob } \\
\text { iano }\end{array}$ & $\begin{array}{r}86,14^{\mathrm{A}} \\
( \pm 4,11)\end{array}$ & $\begin{array}{l}167,76^{\mathrm{A}} \\
( \pm 17,61)\end{array}$ & $\begin{array}{r}75,43^{\mathrm{A}} \\
( \pm 6,46)\end{array}$ & $\begin{array}{r}142,54^{\mathrm{A}} \\
( \pm 38,97)\end{array}$ & $\begin{array}{l}86,75^{\mathrm{A}} \\
( \pm 4,16)\end{array}$ & $\begin{array}{l}242,55^{\mathrm{A}} \\
( \pm 60,91)\end{array}$ & $\begin{array}{r}64,55^{\mathrm{A}} \\
( \pm 6,65)\end{array}$ & $\begin{array}{l}18,48^{\mathrm{A}} \\
( \pm 4,4)\end{array}$ \\
\hline $\begin{array}{c}\text { Sem } \\
\text { antimicrob } \\
\text { iano }\end{array}$ & $\begin{array}{l}78,97^{\mathrm{A}} \\
( \pm 6,38)\end{array}$ & $\begin{array}{l}180,49^{\mathrm{A}} \\
( \pm 22,32)\end{array}$ & $\begin{array}{l}63,96^{\mathrm{A}} \\
( \pm 8,2)\end{array}$ & $\begin{array}{l}149,18^{\mathrm{A}} \\
( \pm 42,15)\end{array}$ & $\begin{array}{l}76,89^{\mathrm{A}} \\
( \pm 7,25)\end{array}$ & $\begin{array}{l}54,69^{\mathrm{B}} \\
( \pm 0,51)\end{array}$ & $\begin{array}{r}47,94^{\mathrm{A}} \\
( \pm 8,5)\end{array}$ & $\begin{array}{l}18,93^{\mathrm{A}} \\
( \pm 4,34)\end{array}$ \\
\hline P & 0,35 & 0,65 & 0,29 & 0,9 & 0,25 & 0,006 & 0,13 & 0,94 \\
\hline
\end{tabular}

Com antimicrobiano $=$ amostras que receberam norfloxacina in vitro

Sem antimicrobiano $=$ amostras que não receberam norfloxacina in vitro

Letras Maiúsculas diferentes indicam $\mathrm{P} \leq 0,05$ entre os grupos experimentais.

Quando a produção de ERO por células $\mathrm{CD} 14^{+}$foi estimulada pela presença de bactérias, somente a IMF da produção intracelular de ERO estimulada por S. aureus foi maior no grupo que recebeu antimicrobiano in vitro.

Na tabela 40 estão representados os valores das médias e dos erros padrão das células $\mathrm{CD}_{14}{ }^{+}$que fagocitaram $M$. haemolytica, S. aureus e E. coli desafiadas in vitro com antimicrobiano norfloxacina.

Tabela 40 - Efeito in vitro da norfloxacina sobre a porcentagem de células CD14 ${ }^{+}$que fagocitaram Mannheimia haemolytica, Staphylococcus aureus e Escherichia coli no sangue de bezerros sadios - São Paulo 2014

\begin{tabular}{|c|c|c|c|c|c|c|}
\hline \multirow[b]{2}{*}{ Grupos } & \multicolumn{2}{|c|}{ M. haemolytica } & \multicolumn{2}{|c|}{ S. aureus } & \multicolumn{2}{|c|}{ E.coli } \\
\hline & $\begin{array}{c}\text { Fagocitose } \\
(\%)\end{array}$ & $\begin{array}{c}\text { Intensidade } \\
\text { de } \\
\text { Fluorescência }\end{array}$ & $\begin{array}{c}\text { Fagocitose } \\
(\%)\end{array}$ & $\begin{array}{c}\text { Intensidade } \\
\text { de } \\
\text { Fluorescência }\end{array}$ & $\begin{array}{c}\text { Fagocitose } \\
(\%)\end{array}$ & $\begin{array}{l}\text { Intensidade } \\
\text { de } \\
\text { Fluorescência }\end{array}$ \\
\hline Com & $46,16^{\mathrm{A}}$ & $38,29^{\mathrm{A}}$ & $77,63^{\mathrm{A}}$ & $136,30^{\mathrm{A}}$ & $77,28^{\mathrm{A}}$ & $369,27^{\mathrm{A}}$ \\
\hline antimicrobiano & $( \pm 5,85)$ & $( \pm 4,79)$ & $( \pm 8,68)$ & $( \pm 25,71)$ & $( \pm 9,08)$ & $( \pm 48,22)$ \\
\hline Sem & $\begin{array}{l}48,02^{\mathrm{A}} \\
(+5,74)\end{array}$ & $\begin{array}{l}31,45^{\mathrm{A}} \\
(+3,95)\end{array}$ & $\begin{array}{c}69,95^{\mathrm{A}} \\
(+1077)\end{array}$ & $\begin{array}{l}119,74^{\mathrm{A}} \\
(+15,92)\end{array}$ & $\begin{array}{c}65,35^{\mathrm{A}} \\
(+10,56)\end{array}$ & $\begin{array}{l}215,29^{\mathrm{B}} \\
(+40,76)\end{array}$ \\
\hline $\mathrm{P}$ & 0,82 & 0,28 & 0,58 & 0,59 & 0,4 & 0,02 \\
\hline
\end{tabular}

Com antimicrobiano $=$ amostras que receberam norfloxacina in vitro

Sem antimicrobiano $=$ amostras que não receberam norfloxacina in vitro

Letras Maiúsculas diferentes indicam $\mathrm{P} \leq 0,05$ entre os grupos experimentais.

No ensaio realizado para as provas de fagocitose com as diferentes bactérias por células $\mathrm{CD}_{14}{ }^{+}$do sangue, notou-se apenas maior IMF de fagocitose E. coli por essas células no grupo que recebeu o antimicrobiano in vitro. 
$\mathrm{Na}$ tabela 41 estão representados os valores da produção e IMF de ERO basal e estimulados por M. haemolytica, S. aureus e E. coli, dos granulócitos do sangue. A adição do antimicrobiano reduziu a porcentagem de granulócitos que produziram ERO basal.

Tabela 41 - Efeito in vitro da norfloxacina sobre a porcentagem de células $\mathrm{CH}_{138^{+}}$que produziram espécies reativas de oxigênio e intensidade de fluorescência (IMF) em valores arbitrários basal e estimulados por Mannheimia haemolytica, Staphylococcus aureus e Escherichia coli no sangue de bezerros sadios - São Paulo - 2014

\begin{tabular}{|c|c|c|c|c|c|c|c|c|}
\hline \multirow[t]{2}{*}{ Grupos } & \multicolumn{2}{|c|}{ Não estimulado } & \multicolumn{2}{|c|}{$\begin{array}{c}\text { Estimulado por } M \text {. } \\
\text { haemolytica }\end{array}$} & \multicolumn{2}{|c|}{$\begin{array}{c}\text { Estimulado por } S \text {. } \\
\text { aureus }\end{array}$} & \multicolumn{2}{|c|}{$\begin{array}{l}\text { Estimulado por } \\
\text { E.coli }\end{array}$} \\
\hline & $(\%)$ & IMF & $(\%)$ & IMF & $(\%)$ & IMF & $(\%)$ & IMF \\
\hline $\begin{array}{c}\text { Com } \\
\text { antimicrob } \\
\text { iano }\end{array}$ & $\begin{array}{r}86,43^{\mathrm{B}} \\
( \pm 5,34)\end{array}$ & $\begin{array}{c}406,97^{\mathrm{A}} \\
( \pm 67,63)\end{array}$ & $\begin{array}{l}96,13^{\mathrm{A}} \\
( \pm 1,11)\end{array}$ & $\begin{array}{r}706,50^{\mathrm{A}} \\
( \pm 147,35)\end{array}$ & $\begin{array}{r}86,74^{\mathrm{A}} \\
( \pm 6,33)\end{array}$ & $\begin{array}{r}1305,0^{\mathrm{A}} \\
( \pm 784,56)\end{array}$ & $\begin{array}{l}85,16^{\mathrm{A}} \\
( \pm 5,7)\end{array}$ & $\begin{array}{r}367,97^{\mathrm{A}} \\
( \pm 109,43)\end{array}$ \\
\hline $\begin{array}{c}\text { Sem } \\
\text { antimicrob } \\
\text { iano }\end{array}$ & $\begin{array}{l}99,13^{\mathrm{A}} \\
( \pm 0,3)\end{array}$ & $\begin{array}{l}374,00^{\mathrm{A}} \\
( \pm 78,39)\end{array}$ & $\begin{array}{l}93,87^{\mathrm{A}} \\
( \pm 2,15)\end{array}$ & $\begin{array}{c}587,21^{\mathrm{A}} \\
( \pm 119,73)\end{array}$ & $\begin{array}{l}86,56^{\mathrm{A}} \\
( \pm 5,99)\end{array}$ & $\begin{array}{l}442,08^{\mathrm{A}} \\
( \pm 39,06)\end{array}$ & $\begin{array}{l}89,43^{\mathrm{A}} \\
( \pm 3,51)\end{array}$ & $\begin{array}{l}273,17^{\mathrm{A}} \\
( \pm 44,3)\end{array}$ \\
\hline $\mathbf{P}$ & 0,02 & 0,75 & 0,35 & 0,54 & 0,98 & 0,28 & 0,53 & 0,43 \\
\hline
\end{tabular}

Com antimicrobiano $=$ amostras que receberam norfloxacina in vitro

Sem antimicrobiano $=$ amostras que não receberam norfloxacina in vitro

Letras Maiúsculas diferentes indicam $\mathrm{P} \leq 0,05$ entre os grupos experimentais.

Na tabela 42 estão representados os valores das médias e dos erros padrão das células $\mathrm{CH} 138^{+}$que fagocitaram M. haemolytica, S. aureus e E. coli e que foram desafiadas in vitro com antimicrobiano.

Tabela 42 - Efeito in vitro da norfloxacina sobre a porcentagem de células $\mathrm{CH} 138^{+}$que fagocitaram Mannheimia haemolytica, Staphylococcus aureus e Escherichia coli no sangue de bezerros sadios - São Paulo 2014

\begin{tabular}{|c|c|c|c|c|c|c|}
\hline \multirow[b]{2}{*}{ Grupos } & \multicolumn{2}{|c|}{ M. haemolytica } & \multicolumn{2}{|c|}{ S. aureus } & \multicolumn{2}{|c|}{ E.coli } \\
\hline & $\begin{array}{c}\text { Fagocitose } \\
(\%)\end{array}$ & $\begin{array}{l}\text { Intensidade } \\
\text { de } \\
\text { Fluorescência }\end{array}$ & $\begin{array}{l}\text { Fagocitose } \\
(\%)\end{array}$ & $\begin{array}{c}\text { Intensidade } \\
\text { de } \\
\text { Fluorescência }\end{array}$ & $\begin{array}{c}\text { Fagocitose } \\
(\%)\end{array}$ & $\begin{array}{c}\text { Intensidade } \\
\text { de } \\
\text { Fluorescência }\end{array}$ \\
\hline Com & $77,45^{\mathrm{A}}$ & $30,22^{\mathrm{B}}$ & $49,30^{\mathrm{A}}$ & $208,70^{\mathrm{A}}$ & $32,69^{\mathrm{A}}$ & $315,13^{\mathrm{B}}$ \\
\hline antimicrobiano & $( \pm 8,33)$ & $( \pm 7,65)$ & $( \pm 3,06)$ & $( \pm 84,2)$ & $( \pm 7,24)$ & $( \pm 51,25)$ \\
\hline $\begin{array}{c}\text { Sem } \\
\text { antimicrobiano }\end{array}$ & $\begin{array}{l}76,93^{\mathrm{A}} \\
( \pm 8,53)\end{array}$ & $\begin{array}{c}87,02^{\mathrm{A}} \\
( \pm 18,74)\end{array}$ & $\begin{array}{l}39,70^{\mathrm{A}} \\
( \pm 5,73)\end{array}$ & $\begin{array}{l}146,95^{\mathrm{A}} \\
( \pm 18,17)\end{array}$ & $\begin{array}{l}27,66^{\mathrm{A}} \\
( \pm 5,86)\end{array}$ & $\begin{array}{l}597,33^{\mathrm{A}} \\
( \pm 48,44)\end{array}$ \\
\hline P & 0,96 & 0,008 & 0,15 & 0,44 & 0,59 & 0,0006 \\
\hline
\end{tabular}

Com antimicrobiano $=$ amostras que receberam norfloxacina in vitro

Sem antimicrobiano $=$ amostras que não receberam norfloxacina in vitro

Letras Maiúsculas diferentes indicam $\mathrm{P} \leq 0,05$ entre os grupos experimentais.

O antimicrobiano também reduziu a IMF da fagocitose de $M$. haemolytica e $E$. coli por granulócitos. 
ODiscussáa 


\section{DISCUSSÃO}

No presente estudo foi possível observar que houve alterações das variáveis analisadas de acordo com o estadiamento da doença e da terapia utilizada. Tais alterações foram evidenciadas principalmente no momento em que os animais apresentaram manifestações compatíveis com a doença, retornando à sua condição fisiológica após o tratamento. Ademais, apesar de algumas alterações na resposta sistêmica, durante o quadro infeccioso as alterações locais foram mais perceptíveis.

\subsection{EXAME FÍSICO}

Quais são os critérios que definiriam o que é um bezerro sadio e quando esse animal seria considerado acometido por broncopneumonia? Observando a literatura compulsada constatou-se que para a maioria dos autores (GONÇALVES et al., 2000; GODINHO et al., 2007; ANGEN et al., 2009; BRSCIC et al., 2012; LERUSTE et al., 2012; AMRINE et al., 2013; LOVE et al., 2014; OLLIVETT, 2014; PARDON et al., 2015; TAYLOR et al., 2015) bastava observar os aspectos clínicos da doença, tais como alteração no padrão respiratório, tosse espontânea e secreção nasal, em geral confirmadas pelo aumento de temperatura retal, também observados no presente estudo. Manifestações essas que foram amenizadas uma semana após o tratamento e desapareceram em duas semanas em ambos os grupos, assim como observado por Thiry et al. (2014) utilizando uma combinação de florfenicol e flunixina meglumina e por Ozkanlar et al. (2012), que observou recuperação clínica após 15 dias do tratamento com tulatromicina.

Temperatura retal e frequências cardíaca e respiratória também foram utilizadas para predizer a doença respiratória, pois esses parâmetros clínicos se alteram na doença (FAGLIARI, 2003). Contudo, no presente estudo, a frequência cardíaca não diferiu entre os tempos assim como entre os grupos, como observado por Rezende (2010). Hanzlicek et al. (2010) observaram aumento da frequência cardíaca, mas só consideraram como uma manifestação importante da doença quando em concomitância com o aumento da frequência respiratória, e que essa alteração se deve à tentativa do animal obter oxigênio hiperventilando, uma vez que a bactéria causa lesão tecidual e consolidação dos alvéolos (AULIK; 
HELLENBRAND; CZUPRYNSKI, 2012; OZKANLAR et al., 2012; SINGH et al., 2012; AYALEW et al., 2013) o que pode também estar relacionado à tentativa de controlar a temperatura corpórea (GONÇALVES; FEITOSA, 2008)

De acordo com Hanzlicek et al. (2010) o aumento de temperatura pode estar associado ao quadro pneumônico, porém este é influenciado pela temperatura ambiente, divergindo do encontrado por diversos autores (GONÇALVES et al., 2000; FAGLIARI, 2003; GODINHO et al., 2007; LOVE et al., 2014) que observaram aumento da temperatura retal diretamente relacionado com a manifestação clínica da doença, assim como no presente estudo.

Após o tratamento foi observada a normalização da temperatura retal e da frequência respiratória desses animais, assim como observado por Bednarek et al. (2013) e Thiry et al. (2014) que utilizaram a associação farmacológica florfenicol - flunixina meglumina.

\subsubsection{Inspeção Indireta}

Utilizou-se o animal no momento anterior a inoculação como controle de si mesmo e padrão de normalidade para a descrição da doença. Deste modo pode-se estabelecer o que era normal para a espécie, ou seja, foram considerados sadios os animais com mucosas rosadas, úmidas e brilhantes, sem a presença de edema de mucosa e congestão de vasos e mucosas e que não apresentavam secreção mucopurulenta (THRUNAVUKKARASU et al., 2005; BATISTA, 2011).

O exame realizado no momento das manifestações clínicas apresentou grande quantidade de secreção fibrinonecrótica de coloração que variava de amarelo palha a verde, mucosas avermelhadas, vasos bem evidentes, edema de mucosa e nítido incômodo, quando o aparelho estava sendo introduzido. Uma semana após o tratamento, essas alterações amenizaram e duas semanas após, os animais voltaram à sua condição inicial. Poucos trabalhos descrevem essas alterações durante o quadro pneumônico. Potgieter et al. (1984) realizaram a eutanásia dos animais três dias após a inoculação, realizando a observação dos sinais macroscópicos da doença durante a necropsia, assim como a maioria dos trabalhos compulsados, que avaliou as lesões e alterações pós-morte (BROGDEN; ACKERMANN; DEBEY, 1995; BRITTON; ZABEK, 2012; HERMEYER et al., 2012). Thrunavukkarasu et al. 
(2005) observaram alterações broncoscópicas durante quadros pneumônicos, porém não em quadros de mannheimiose, e não acompanharam a evolução da doença e do tratamento.

\subsection{CULTURA BACTERIOLÓGICA}

Para assegurar um tratamento eficaz da doença, veterinários e pesquisadores precisam confirmar a presença do agente e determinar a sensibilidade a antimicrobianos, durante surtos de CDRB nas explorações e em estudos clínicos (GODINHO et al., 2007; COOPER; BRODERSEN, 2010).

Para essa finalidade, diferentes métodos de colheita são utilizados, tais como suabe nasal (COUTINHO et al., 2009; TAYLOR et al., 2015) ou nasofaríngeo (GODINHO et al., 2007; COUTINHO et al., 2009), lavado traqueobrônquico (ANGEN et al., 2009; BENESI et al., 2012; BENESI et al., 2013) ou lavado broncoalveolar (BENESI et al., 2012). No presente estudo optou-se pela utilização do lavado traqueobrônquico e pelo suabe nasal para a pesquisa de microrganismos no trato respiratório.

No presente trabalho, o intuito dessas coletas era demonstrar que antes das inoculações os animais não apresentavam infecção, por $M$. haemolytica, apresentando apenas as bactérias comensais, e após o tratamento mostrar que o mesmo foi eficiente resultando na cura clínica e bacteriológica da doença.

Apesar da literatura citar P. multocida, M. haemolytica, H. somni, Trueperella pyogenes (anteriormente Arcanobacterium pyogenes) como os agentes mais comumente isolados do trato respiratório posterior de bezerros sadios e com broncopneumonia (GODINHO et al., 2007; ANGEN et al., 2009; GRIFFIN, 2010; GRIFFIN et al., 2010; HOTCHKISS et al., 2010) estes agentes não foram encontrados na presente pesquisa nos animais sadios (momentos M1, M3 e M4), assim como observado por Benesi et al. (2013) e Coutinho et al. (2009) que encontraram Staphylococcus sp., Streptococcus sp., Bacillus sp. na maioria das amostras. Na presente pesquisa houve ainda algumas amostras que não apresentaram crescimento bacteriano, diferindo dos demais autores.

Semelhante ao descrito por Coutinho et al. (2009) nos animais inoculados, foi encontrada a presença da $M$. haemolytica em $100 \%$ das amostras de suabe nasal no momento M2. Pode-se dizer que as frequências de isolamento da M. haemolytica nos suabes nasal colhidos antes e após a indução da broncopneumonia delinearam padrões típicos de 
colonização das vias aéreas anteriores por esta bactéria, quando os bezerros estavam sadios e quando desenvolveram a doença (COUTINHO et al., 2009).

A norfloxacina foi eficaz no tratamento da mannheimiose, como foi possível observar pela regressão do quadro pneumônico após o tratamento e ausência de re-isolamento de $M$. haemolytica na cultura bacteriológica, no M3 e M4 do suabe nasal e do lavado traqueobrônquico. Neste contexto sabe-se que as fluorquinolonas representam uma das classes de agentes antimicrobianos bastante utilizadas em medicina humana e veterinária (PEREIRA; SIQUEIRA; CAMPOS TAKAKI, 2004; SALEH et al., 2013) e, o sucesso dessa classe de antimicrobianos, deve-se ao seu amplo espectro de atividade, toxidade mínima sobre eucariotos, fácil penetração na maioria das células bacterianas e boas propriedades farmacocinéticas (BROWN, 1996; BLONDEAU, 1999). Elas são empregadas particularmente contra infecções do trato urinário e doenças respiratórias agudas (SALEH et al., 2013).

\subsection{AVALIAÇÃO CITOLÓGICA DO LBA}

O principal tipo de célula mediadora das defesas pulmonares são os fagócitos mononucleares, principalmente macrófagos, que não representam o único tipo celular encontrado no espaço alveolar. Linfócitos, neutrófilos e células epteliais também são encontrados no LBA e contribuem para essa defesa (KHADOM; DEDIEU; VISO, 1985; JUNGI et al., 1997). Macrófagos alveolares representam as células mais frequentes no LBA de indivíduos saudáveis (LOHMEYER et al., 1994; GONÇALVES et al., 2004; GARN, 2006), corroborados pelos dados do presente estudo. Diferenciam-se pela permanência no pulmão e por aspectos funcionais e desempenham um papel importante na depuração pulmonar e resistência do hospedeiro às infecções bacterianas e virais (MYRVIK; LEAKE; FARISS, 1961; HEARST; WARR; JAKAB, 1980).

A presença de células gigantes encontradas no presente estudo, pode ser explicada pela capacidade que os macrófagos tem em se juntar para englobar e destruir agentes estranhos, formando sincícios que limitam o agente agressor (GONÇALVES et al., 2004). Essa propriedade das células fagocitárias está relacionada à diferenciação dos macrófagos quando, numa mesma célula, podem ser observados vários núcleos. A presença de dois, três ou mais núcleos caracteriza, respectivamente, os macrófagos bi, tri nucleados e as células gigantes (SWEENEY; HUMBER; ROBY, 1992). 
Durante a infecção pode-se observar aumento da quantidade de neutrófilos e uma diminuição na população de macrófagos, similarmente ao descrito por Fagliari (2003); Youssef, Clark e Caswell (2004); Hanzlicek et al. (2010) e Sathiamoorthy et al. (2012).

Logo após a entrada do patógeno invasor, os leucócitos residentes, juntamente com as células epiteliais, iniciam a resposta inflamatória necessária para eliminar a bactéria invasora. Estas células liberam quimioatrativos e citocinas para o rápido recrutamento de neutrófilos para o local da inflamação (PAAPE et al., 2003), corroborando com o aumento da porcentagem de neutrófilos encontrada no LBA no presente estudo, indicando o orquestramento da resposta imune e o sucesso da infecção experimental como observado também por Mcclenahan et al. (1999).

\subsection{AVALIAÇÃO DO LAVADO BRONCOALVEOLAR}

A alta incidência da doença motivaram muitos estudos sobre a patogenia da afecção, encontrando infiltração neutrofílica maciça no pulmão (FAGLIARI, 2003; YOUSSEF; CLARK; CASWELL, 2004; HANZLICEK et al., 2010; SATHIAMOORTHY et al., 2012). No entanto não se encontrou informações sobre o quanto este microrganismo pode comprometer a função de fagócitos sanguíneos e pulmonares, ponto chave para melhor entendimento da patogenia desta infecção e para buscar terapias mais promissoras.

\subsubsection{Fenotipagem das células mononucleares do LBA}

Existe uma grande quantidade de debris celulares e não celulares que por alterar o tamanho e a granulosidade das células dificultaram a sua identificação por citometria de fluxo, desta maneira optou-se por utilizar a seleção da população de mononucleares de acordo com Lohmeyer et al. (1994); Raidal, Bailey e Love (1998a); Soethout et al. (2004) e Batista et al. (2012), na forma de gates.

A estratégia utilizada foi definir dentro do gate quem realmente era leucócito, excluindo os debris celulares e não celulares, por meio da marcação com a molécula de 
superfície de pan-leucócitos CD45 (MCINNES et al., 1999; BARRY et al., 2002). Dentro da população do gate, entre 50 e $70 \%$ era de CD45, ou seja, leucócitos, ao longo do tempo, semelhante ao encontrado por Barry et al. (2002) em humanos, onde $61 \%$ da população do LBA era de CD45. Esses autores afirmam que a população CD45- era composta por debris não celulares, células epitélio-bronquiais e células de descamação.

Dentro da população de leucócitos observou-se predomínio da população de células $\mathrm{CD}_{14}^{+}$, majoritariamente representadas pela população de macrófagos (OLIVEIRA; MCCLELLAN; HANSEN, 2010; BATISTA et al., 2012; SLÁDEK; RYŠÁNEK, 2014), como observado também na citologia, corroborado pela redução dessa população no M2.

Embora o aumento das células $\mathrm{T} \mathrm{CD}^{+}$e $\mathrm{T} \gamma \delta$ pareça enigmático no contexto da inflamação pulmonar, sabe-se que as células da linhagem Th17 tem importante papel na defesa contra patógenos extracelulares na resposta de mucosa (AUJLA; DUBIN; KOLLS, 2007). As células T CD8 ${ }^{+}$e T $\gamma \delta$ são importantes produtoras de IL-17 durante os estágios iniciais da resposta contra patógenos extracelulares (PECK; MELLINS, 2010), que são capazes de regular a resposta neutrofílica, incluindo a indução do recrutamento de neutrófilos (MATHY et al., 2002; AUJLA; DUBIN; KOLLS, 2007; PELLETIER et al., 2010). Além disso, as alterações das funções pulmonares estão intimamente relacionadas às células $\mathrm{T}$ $\mathrm{CD}^{+}$, particularmente nas doenças pulmonares intersticiais com apresentação aguda (ENELOW et al., 1998), como comumente encontrado nas pneumonias causadas pela $M$. haemolytica.

\subsubsection{Provas funcionais dos fagócitos do LBA}

Embora não tenha sido evidenciada diferença estatística nas porcentagens de ERO pelas células $\mathrm{CD}_{14}{ }^{+}$no LBA, tanto na produção basal quanto nas estimuladas pelas distintas bactérias em ambos os grupos, o comportamento da IMF das mesmas não acompanhou o da porcentagem de células $\mathrm{CD}_{1} 4^{+}$que produziram ERO, uma vez que as amostras estimuladas por $E$. coli e $S$. aureus diminuíram sua intensidade no momento pós tratamento em ambos os grupos. Nas amostras estimuladas com $M$. haemolytica foi observado aumento no momento seguinte ao tratamento somente no grupo não tratado com anti-inflamatório, o que nos leva à hipótese que o anti-inflamatório diminuiu a resposta inflamatória referida por Grell et al. 
(2005a, 2005b) e Antonis et al. (2010), diminuindo a possibilidade de danos teciduais no parênquima pulmonar no grupo tratado que não apresentou diferença na intensidade.

Mesmo não alterando a porcentagem de produção intracelular de ERO, esse aumento da IMF demonstra a capacidade da célula que está desempenhando esse papel tem em eliminar o patógeno, pois quando ocorre alteração na capacidade dessas células gerarem ERO elas diminuem a sua capacidade de combater o agente invasor (RINALDI et al., 2008).

Quando a produção de ERO por células $\mathrm{CD} 14^{+}$do LBA foi analisada e comparada entre os estímulos bacterianos, verificou-se que a produção foi mais intensa nas células que foram estimuladas com $M$. haemolytica demonstrando resposta mais específica ao patógeno causador da infecção nos animais.

Os resultados da fagocitose dos três patógenos mostraram aumento da porcentagem deste fenômeno, após o tratamento, principalmente duas semanas após (M4). Acredita-se que a maior porcentagem de fagocitose após o tratamento, esteja ligada à eficiência do antimicrobiano em auxiliar a funcionalidade das células locais em controlar os agentes infecciosos, incrementando a função de fagocitose, como já foi observado por outros autores quando estudavam a interação de antimicrobianos com as células do leite em infecções mamárias (DOSOGNE et al., 1998; BATISTA et al., 2009).

Outra hipótese é que logo após a expressiva migração de neutrófilos para o sítio inflamatório e do acúmulo de debris celulares resultantes do processo de reparo do quadro infeccioso, os macrófagos são recrutados na tentativa de limitar o dano tecidual (KOBAYASHI; VOYICH; DELEO, 2003; PAAPE et al., 2003). Este recrutamento resulta em aumento da viabilidade dessa população celular local, levando consequentemente ao aumento da capacidade fagocítica das células CD14+ do LBA (SLÁDEK; RYŠÁNEK, 2000, 2001, 2010).

\subsubsection{Viabilidade de mononucleares do LBA}

No presente estudo foi realizada a prova de viabilidade nas células $\mathrm{CD}_{1} 4^{+}$do LBA, onde foi observado que no momento da infecção, as porcentagens de apoptose dessas células diminuem em relação aos momentos em que o animal estava sadio ou tratado. Neste mesmo momento (M2) foi observado maior porcentagem de necrose dessas células. Isso pode ser explicado pela presença do patógeno em grandes quantidades no local, produzindo dano 
tecidual e rompendo a barreira das defesas locais e intensificando a inflamação (VAN OOSTVELDT et al., 2002). Esses autores avaliaram o efeito da apoptose na fagocitose, explosão respiratória e expressão de moléculas de adesão em bovinos, e referiram que a fagocitose pode ser modulada pelo estímulo da apoptose, mas na presença de outro estímulo predominante, pode incorrer em necrose e agudização do processo inflamatório.

Diante de um processo infeccioso intenso e/ou agudo, devido à grande quantidade de neutrófilos, os macrófagos não conseguem eliminar os neutrófilos que estão entrando em apoptose, que acabam liberando o conteúdo citoplasmático no tecido, o que é tóxico para as outras células e provocam a morte destas por necrose (VAN OOSTVELDT et al., 2002). Este fato corrobora com os resultados de fagocitose observados no tópico anterior.

Outra hipótese para esse aumento na necrose seria a de que a leucotoxina da $M$. haemolytica possui a capacidade de induzir apoptose em leucócitos bovinos, porém na presença de citocinas inflamatórias, como a IL-1 $\beta$ e TNF- $\alpha$, essas células sofrem necrose (LEITE et al., 2002; RICE et al., 2007). Uma outra forma de responder isso seria pelo simples fato de infecções ou isquemias induzirem necrose (GOLSTEIN; KROEMER, 2007), pois envolvem fatores de reconhecimento de morte celular como o TNF- $\alpha$.

Ao combater os patógenos causadores da infecção, as células produzem ERO que auxiliam na eliminação do microrganismo, mas ao mesmo tempo podem causar dano tecidual (TIZARD, 2014). Assim, não só a apoptose, mas também a fagocitose dos corpúsculos apoptóticos são importantes na resolução da inflamação e, a desregulação desses processos, pode contribuir na persistência da inflamação, tornando-a crônica (FOX et al., 2010).

\subsection{AVALIAÇÃO DO SANGUE}

Além de conhecer melhor a resposta imune local, é importante dimensionar o efeito da infecção na resposta imune sistêmica, para contribuir com a melhor intervenção terapêutica a ser adotada. 


\subsubsection{Leucograma}

A contagem total de leucócitos, assim como a dos neutrófilos aumentou durante o processo infeccioso, indicando de uma forma simples, a influência da mannheimiose na defesa imunológica sistêmica como relatado por Bednarek, Kondracki e Niemczuk (2001) e indiretamente, no expressivo recrutamento dos neutrófilos para o local da infecção. Assim como a diminuição após o tratamento reflete a sua eficácia, pois como observado por Maślanka et al. (2010) a flunixina meglumina induz morte de células neutrofílicas do sangue, como observado no grupo G1 que apresentou diminuição na porcentagem de neutrófilos após o tratamento.

\subsubsection{Fenotipagem das células do sangue}

A imunofenotipagem dos leucócitos sanguíneos demonstrou redução na porcentagem de linfócitos $\mathrm{T} \mathrm{CD} 8^{+}$e $\mathrm{T} \gamma \delta$ no momento da apresentação do quadro clínico, o que pode ter ocorrido devido ao recrutamento destas subpopulações celulares para o sítio inflamatório, considerando os achados no LBA, discutidos anteriormente.

A L-selectina está relacionada ao processo inicial de adesão dos neutrófilos circulantes ao endotélio vascular. A expressão e rápida ativação de Mac-1 (CD11b/CD18) é essencial para a subsequente migração do neutrófilo para o sítio inflamatório. Após a ativação do Mac-1, a L-selectina é liberada para a superfície celular por proteólise (CAVERLY et al., 2001; DIEZ-FRAILE et al., 2003; DELLA LIBERA et al., 2015). Considerando os achados da expressão de L-selectina pelos neutrófilos sanguíneos, observou-se significante decréscimo da expressão desta no momento da manifestação do quadro clínico de mannheimiose, o que sugere uma tentativa do organismo de manter a homeostase. Neste contexto, Ferri et al. (2009) demonstraram que em vários estudos clínicos há aumento da L-selectina na forma solúvel, indicando papel crucial no controle do processo inflamatório, evitando danos ao tecido pulmonar e a morte em pacientes com quadro séptico, minimizando o dano microvascular ocasionado pela infiltração leucocitária, devido ao decréscimo das citocinas que ocasionam o aumento da permeabilidade vascular. Deste modo a redução da expressão de L-selectina pelos neutrófilos foi correlacionada com a intensidade da resposta inflamatória, 
sendo, portanto, a liberação da L-selectina dos neutrófilos proporcional à intensidade do processo inflamatório.

\subsubsection{Provas funcionais dos fagócitos do sangue}

A produção intracelular de ERO basal por células $\mathrm{CD}_{14}{ }^{+}$e $\mathrm{CH} 138^{+}$e estimulados por M. haemolytica em neutrófilos $\mathrm{CH}_{138^{+}}$foi maior no momento da manifestação clínica da mannheimiose, o que pode ser decorrente da produção de citocinas inflamatórias, como o TNF- $\alpha$, IL1- $\beta$ ou INF- $\gamma$ durante o processo infeccioso (LEITE et al., 2002; KIM et al., 2010; SINGH; RITCHEY; CONFER, 2011). Estas citocinas, por outro lado, induzem a expressão de Mac-1 que está associado ao aumento da capacidade de ligação da leucotoxina aos leucócitos bovinos e consequentemente à morte celular (LEITE et al., 2002; GOLSTEIN; KROEMER, 2007; KIM et al., 2010). Estes fatos corroboram com o aumento da morte celular observada durante o processo infeccioso por mannheimiose tanto no LBA quanto no sangue no presente estudo. Valores esses que foram reestabelecidos após cura clínica e bacteriológica resultantes do tratamento. Aumento da produção de superóxido e nitrito pelos neutrófilos de bovinos após exposição a diferentes concentrações de LPS e leucotoxina da $M$. haemolytica também já foi descrita (WESSELY-SZPONDER et al., 2005). Além disto, sabe-se que a molécula de adesão da $M$. haemolytica (MhA) induz significativo aumento da produção de ERO; essa molécula tem capacidade de se ligar aos neutrófilos, e em menor quantidade aos monócitos (DE LA MORA et al., 2006).

A porcentagem de fagocitose de $M$. haemolytica pelas células $\mathrm{CD}_{14}{ }^{+}$sanguíneas foi maior após tratamento. Isto provavelmente deve-se ao fato da presença de anticorpos específicos contra $M$. haemolytica presentes no sangue total, sete e 14 dias após a indução do processo infeccioso, aumentando a opsonização bacteriana e consequentemente a fagocitose. No entanto, a porcentagem e a IMF de fagocitose de $S$. aureus e E. coli pelas células CD14+ sanguíneas foi menor durante as manifestações clínicas do processo infeccioso. Similarmente Confer e Simons (1986) descreveram que a fagocitose de $S$. aureus foi menor em alta e baixa concentração de lipopolissacáride de $M$. haemolytica.

No entanto, a IMF de fagocitose de $M$. haemolytica por células $\mathrm{CD}_{14}{ }^{+}$sanguíneas foi maior no $\mathrm{M} 2$, o que provavelmente se deve às citocinas produzidas durante o processo infecioso, como por exemplo o INF- $\gamma$. Neste contexto Zhao, Collins e Czuprynski (1997) 
relataram aumento da capacidade fagocítica após pré-tratamento de monócitos com INF- $\gamma$ recombinante.

A IMF de fagocitose de $M$. haemolytica por neutrófilos foi menor durante a manifestação clínica da mannheimiose, o que pode ser devido às proteínas de membrana externa da M. haemolytica, como previamente descrito por Iovane et al. (1998).

\subsubsection{Viabilidade dos fagócitos do sangue}

As células monocíticas do sangue apresentaram o mesmo comportamento para as quatro populações distintas (apoptose, necrose, apoptose e/ou necrose e células viáveis), assim como observado nas células $\mathrm{CD}_{1}{ }^{+}$do LBA. Mas, a população destacada foi a de células em necrose durante o processo infeccioso. Segundo Leite et al. (2002) a leucotoxina da $M$. haemolytica é capaz de induzir apoptose nas células bovinas, porém na presença de citocinas pró-inflamatórias, as células sofrem necrose. O mesmo padrão foi observado para as células polimorfonucleares $\mathrm{CH}_{138^{+}}$, mostrando que as células estavam responsivas ao patógeno invasor, pois infecções podem induzir necrose (GOLSTEIN; KROEMER, 2007).

Apesar de ser em menor número, houve aumento da apoptose no momento M4, após o tratamento nas células monocíticas do grupo que recebeu o anti-inflamatório. Provavelmente isto ocorreu devido ao fato da flunixina meglumina ser um indutor de apoptose em células CD14+ ${ }^{+}$do sangue (MAŚLANKA et al., 2010), para auxiliar as células a diminuir o processo inflamatório em casos de infecção (CHIN et al., 2000; LEE et al., 2004).

A apoptose das células polimorfonucleares, além de prevenir o aumento do processo inflamatório, funcionam como estímulo anti-inflamatório para as outras células (VERMES; HAANEN; REUTELINGSPERGER, 2000; FOX et al., 2010). Esse efeito pôde ser observado no Grupo G1 no momento M3, isto é, as células polimorfonucleares dos animais que receberam anti-inflamatório apresentaram maior porcentagem de apoptose, em relação às células dos animais que não receberam a flunixina meglumina. 


\subsubsection{Expressão gênica de citocinas}

A $M$. haemolytica causa pneumonias graves e durante sua multiplicação, há liberação de neuraminidases, proteases e leucotoxinas, que interferem diretamente na ativação de fagócitos, deflagrando uma resposta inflamatória de maior ou menor intensidade (SINGH; RITCHEY; CONFER, 2011; SINGH et al., 2012). A doença é modulada por citocinas inflamatórias, como o fator de necrose tumoral alfa (TNF- $\alpha$ ), interleucina-1 beta (IL-1 $\beta$ ), e interleucina-8 (IL-8). Estas citocinas inflamatórias contribuem para a patogênese da pneumonia por M. haemolytica recrutando neutrófilos, ativando leucócitos, e induzindo diversos mediadores inflamatórios solúveis (MORSEY et al., 1999; MALAZDREWICH et al., 2001, 2004; OZKANLAR et al., 2012; SINGH et al., 2012). Por esse motivo estas citocinas foram dosadas neste estudo.

Embora existam variados ensaios para detecção de citocinas em humanos e ratos, o mesmo não ocorre para bovinos (MENA et al., 2002; HOLMGREN et al., 2014). Frente as limitadas técnicas, preconizou-se utilizar a técnica mais sensível optando-se pela PCR em tempo real (DENG; LI; TANG, 2003), frequentemente utilizada em pesquisas com citocinas de bovinos (MENA et al., 2002; INGALE et al., 2008; ANTONIS et al., 2010; ALMERÍA et al., 2012; LEACH et al., 2012; GONZÁLEZ-CANO et al., 2014; HOLMGREN et al., 2014). Mesmo sendo uma técnica mais sensível, houve dificuldade em detectar a expressão de algumas citocinas nas células sanguíneas, em especial IL-8. Como ela é muito provavelmente expressa em baixas concentrações, a expressão de seu mRNA não foi detectada pela técnica nas amostras de sangue. Isso indica também, a discreta influência da infecção no momento avaliado na resposta sistêmica.

A IL-8 é uma molécula membro de uma família de citocinas pró-inflamatórias. Embora as atividades melhor caracterizadas de IL-8 sejam a quimiotaxia e ativação de neutrófilos, outros membros desta família têm vasta gama de ações específicas, incluindo a quimiotaxia e ativação de monócitos, quimiotaxia seletiva de células T de memória, inibição de células hematopoiéticas de proliferação celular, e indução de infiltração de neutrófilos in vivo (HOLMES et al., 1991). Porém, sua detecção em animais saudáveis e com infecção aguda nem sempre é realizada, pois essa é mais facilmente detectável em doenças crônicas.

A não detecção de IL-8 nas amostras sanguíneas pode ser explicada pela sua participação na quimiotaxia e na ativação de neutrófilos; essa citocina geralmente está 
presente nos locais de inflamação e infecção (KUNKEL et al., 1991; MITCHELL; ALBRIGHT; CASWELL, 2003; YOON et al., 2010).

Entretanto, a IL-8 pôde ser detectada nas amostras de LBA, e apesar de não ter apresentado diferença entre os momentos, pelo menos numericamente, a sua expressão gênica aumentou no momento da infecção; isso indica provavelmente que o macrófago alveolar parece desempenhar um papel central na geração de fatores pró-inflamatórios, tais como a interleucina-1 (IL-1) e o fator de necrose tumoral (TNF), que são potentes estímulos para as células epiteliais e fibroblastos pulmonares produzirem IL-8. Essa interação é semelhante a uma cascata e pode levar à rápida produção de quantidades significativas de IL-8 no pulmão e recrutar seletivamente neutrófilos para o interstício e/ou do espaço alveolar (KUNKEL et al., 1991; MALAZDREWICH et al., 2004). Segundo Malazdrewich et al. (2001), a IL-8 é a citocina predominante no pulmão durante a mannheimiose.

O TNF- $\alpha$ e a IL-1 $\beta$ são secretados mais precocemente por monócitos e macrófagos, em resposta à agentes patogênicos microbianos e à traumas teciduais (CZUPRYNSKI; NOEL; ADLAM, 1991; KUNKEL et al., 1991; MALAZDREWICH et al., 2004), iniciando a cascata.

A aderência entre os neutrófilos circulantes e endotélio vascular é um passo crítico na migração de neutrófilos, através das paredes dos vasos sanguíneos para o tecido inflamado, e, a IL-1 $\beta$, está relacionada com a expressão de moléculas de adesão vascular (YOON et al., 2010). Tais afirmações corroboram com os resultados encontrados para a expressão gênica da IL-1 $\beta$ no LBA, que apesar de não ser estatisticamente significante, pelo menos numericamente foi maior durante a infecção, o que condiz, pelo menos em parte, com a contagem de neutrófilos na citologia do LBA, sugerindo a migração neutrofílica para o pulmão, durante o processo infeccioso e inflamatório causado pela $M$. haemolytica.

Entre os grupos, somente foi observada uma possível interferência do uso do antiinflamatório no momento M4, para a citocina IL-8 no LBA. Malazdrewich et al. (2004) avaliaram a interferência do uso de um anti-inflamatório esteroidal, a dexametasona, na produção de IL-1 $\beta$, IL-8 e TNF- $\alpha$, durante pneumonias por $M$. haemolytica, e constataram que o uso do medicamento diminui sua produção. No presente estudo não foi possível observar a inibição significativa das citocinas avaliadas, talvez pelo uso do anti-inflamatório não esteroidal, diferentemente do utilizado na pesquisa citada, apesar da discreta interferência na IL-8, provavelmente por ser a maior mediadora da inflamação local (KUNKEL et al., 1991). 
Esses resultados contribuem no planejamento da conduta a ser adotada nas terapias e medidas preventivas das broncopneumonias, minimizando a mortalidade desses animais e prejuízos, no desempenho causado pela doença.

\subsection{DESAFIO FUNCIONAL IN VITRO}

Com o intuito de verificar a eficácia in vitro do antimicrobiano utilizado durante o tratamento dos bezerros, as provas funcionais das células mononucleares CD14 ${ }^{+}$do LBA e das células polimorfonucleares $\mathrm{CH} 138^{+}$e mononucleares $\mathrm{CD} 14^{+}$do sangue foram realizadas, com a adição in vitro do medicamento, antes dos animais serem desafiados com a bactéria. $\mathrm{O}$ intuito deste desafio era demonstrar que para avaliação da eficácia do antimicrobiano, como auxiliador das células no combate à infecção por $M$. haemolytica, não seria necessário inocular animais para tal finalidade, além de verificar o efeito que o medicamento poderia causar nessas células.

\subsubsection{Avaliação nas células do LBA e do sangue}

A terapia antimicrobiana é amplamente utilizada no tratamento de doenças respiratórias em bovinos e, conhecer a doença, facilita na escolha do antimicrobiano a ser utilizado e na duração do tratamento (LORENZ et al., 2011; THIRY et al., 2014).

Quando o animal sofre infecção ele precisa da combinação de defesas próprias e do auxílio de agentes que proporcionem a eliminação do invasor. A eliminação adequada das bactérias exige tanto a eficácia de uma droga antimicrobiana contra o microrganismo, quanto de um sistema de defesa em bom funcionamento (HOEBEN et al., 1997). Portanto, saber se o antimicrobiano escolhido interfere na função celular das células de defesa é importante para o sucesso da terapia (DOSOGNE et al., 1998).

A fagocitose e a produção de ERO são duas das funções mais importantes e essenciais para a eliminação dos microrganismos invasores. A ingestão e morte de bactérias é um processo complexo, que requer um esforço coordenado de várias atividades celulares (KAMPEN et al., 2004). 
Muitos trabalhos analisaram a interferência do tratamento na função celular, mas todos o fizeram aplicando o medicamento nos animais, e não utilizando o ensaio in vitro (CHIN et al., 2000; LEE et al., 2004; FISCHER et al., 2011, 2013).

Sabe-se do efeito antimicrobiano do medicamento sobre as bactérias (GIPS; SOBACK, 1996; VIJAN; CONCI, 2008; MANDIL et al., 2010), mas saber qual sua interferência nas células também é importante para o sucesso terapêutico, e verificar esse efeito in vitro, reduz a utilização de animais, na pesquisa de infecções bacterianas.

Com os resultados obtidos nas análises das funções celulares das células fagocíticas do LBA constatou-se que o comportamento foi muito semelhante ao obtido nas análises das funções do LBA ex vivo. Assim como nas amostras ex vivo, a produção de ERO basal e a estimulada por $M$. haemolytica não apresentou diferença, demonstrando que o tratamento não influencia nessa função.

O antimicrobiano norfloxacina influenciou a atividade fagocítica e a produção intracelular de ERO pelos fagócitos do LBA e sanguíneos, principalmente em relação às bactérias Gram-negativas (E. coli e $M$. haemolytica), o que condiz com o fato das fluorquinolonas, como a norfloxacina, serem especialmente ativas contra bactérias Gramnegativas e em menor proporção contra as Gram-positivas (VIJAN; CONCI, 2008).

Vale salientar que esses resultados foram obtidos utilizando-se doses terapêuticas, e como observado por Hoeben et al. (1997) e Dosogne et al. (1998), quando essas doses são aumentadas, as funções celulares podem ser prejudicadas, como na produção de ERO. O desafio in vitro foi realizado com células de animais saudáveis, e a terapia durante a infecção apresenta outras interferências biológicas que podem influenciar nesses resultados, já que os antimicrobianos podem influenciar no fator de virulência e nas propriedades da parede celular das bactérias, favorecendo sua morte e fagocitose (DOSOGNE et al., 1998), gerando pequenas diferenças nos resultados dos desafios in vitro e ex vivo. 
Condusães 


\section{CONCLUSÕES}

Nas condições deste experimento, com terapia instituída logo após a observação das manifestações clínicas conclui-se que:

Os achados clínicos incluídos os de broncoscopia demonstraram o sucesso da infecção experimental por $M$. haemolytica e a caracterização do processo mórbido, o restabelecimento da condição basal também pode ser verificado após o tratamento com norfloxacina, independentemente do emprego da flunixina meglumina;

A infecção experimental por $M$. haemolytica mostrou alterações nas subpopulações de linfócitos $\mathrm{T} \mathrm{CD}^{+}$e $\gamma \delta$ sanguíneos e do LBA, na produção intracelular de espécies reativas de oxigênio (ERO), na fagocitose e na viabilidade das células CD14 ${ }^{+}$ sanguíneas e do LBA e de granulócitos do sangue e, na expressão de L-selectina pelos leucócitos polimorfonucleares do sangue. Além disso, não se observou benefícios com a utilização adicional do anti-inflamatório nos parâmetros da resposta imune avaliados. Apesar de algumas alterações na resposta imune sistêmica, as alterações locais foram mais perceptíveis.

Nenhuma alteração evidente foi observada na expressão de citocinas IL-1 $\beta$, IL-8 e TNF- $\alpha$ nas células sanguíneas e do LBA;

A norfloxacina também demonstrou in vitro capacidade de alterar as funções dos fagócitos $\mathrm{CD} 14^{+}$sanguíneos e do LBA e, dos granulócitos no sangue. 
Referéncias 


\section{REFERÊNCIAS}

ABBAS, A. K.; LICHTMAN, A. H.; PILLAI, S. Imunologia celular e molecular. 7. ed. Rio de Janeiro: Elsevier, 2012.

ACKERMANN, M. R.; DERSCHEID, R.; ROTH, J. A. Innate immunology of bovine respiratory disease. The Veterinary Clinics of North America. Food Animal Practice, v. 26, n. 2, p. 215-28, jul. 2010.

ALMERÍA, S.; SERRANO, B.; YÀNIZ, J. L.; DARWICH, L.; LÓPEZ-GATIUS, F. Cytokine gene expression profiles in peripheral blood mononuclear cells from Neospora caninum naturally infected dams throughout gestation. Veterinary Parasitology, v. 183, n. 34, p. 237-43, 10 fev. 2012.

AMES, T. R.; BAKER, J. C.; WIKSE, S. E. As Broncopneumonias (Complexo de Doenças Respiratórias de Bovinos, Ovinos e Caprinos). In: SMITH, B. P. (Ed.). Medicina Interna de Grandes Animais. 3a . ed. São Paulo: Manole, 2006. p. 511-570.

AMRINE, D. E.; WHITE, B. J.; LARSON, R.; ANDERSON, D. E.; MOSIER, D. A.; CERNICCHIARO, N. Precision and Accuracy of Clinical Illness Scores, Compared with Pulmonary Consolidation Scores, in Holstein Calves with Experimentally Induced Mycoplasma Bovis Pneumonia. American Journal of Veterinary Research, v. 74, n. 2, p. 310-315, 30 fev. 2013.

ANGEN, Ø.; THOMSEN, J.; LARSEN, L. E.; LARSEN, J.; KOKOTOVIC, B.; HEEGAARD, P. M. H.; ENEMARK, J. M. D. Respiratory disease in calves: Microbiological investigations on trans-tracheally aspirated bronchoalveolar fluid and acute phase protein response. Veterinary Microbiology, v. 137, n. 1, p. 165-171, 2009.

ANTONIS, A. F. G.; DE JONG, M. C.; VAN DER POEL, W. H. M.; VAN DER MOST, R. G.; STOCKHOFE-ZURWIEDEN, N.; KIMMAN, T.; SCHRIJVER, R. S. Age-dependent differences in the pathogenesis of bovine respiratory syncytial virus infections related to the development of natural immunocompetence. The Journal of General Virology, v. 91, n. Pt 10, p. 2497-506, out. 2010.

AUJLA, S. J.; DUBIN, P. J.; KOLLS, J. K. Th17 cells and Mucosal Host Defense. Seminars in Immunology, v. 19, n. 6, p. 337-382, 2007.

AULIK, N. A.; HELLENBRAND, K. M.; CZUPRYNSKI, C. J. Mannheimia haemolytica and its leukotoxin cause macrophage extracellular trap formation by bovine macrophages. Infection and Immunity, v. 80, n. 5, p. 1923-33, maio 2012.

AYALEW, S.; CONFER, A. W.; SHRESTHA, B.; WILSON, A. E.; MONTELONGO, M. Proteomic analysis and immunogenicity of Mannheimia haemolytica vesicles. Clinical and Vaccine Immunology : CVI, v. 20, n. 2, p. 191-6, fev. 2013.

BARRY, S. M.; CONDEZ, A.; JOHNSON, M. A.; JANOSSY, G. Determination of bronchoalveolar lavage leukocyte populations by flow cytometry in patients investigated for respiratory disease. Cytometry, v. 50, n. 6, p. 291-7, 15 dez. 2002. 
BATISTA, C. F. Dinâmica da resposta imune inata do sistema respiratório de bezerros. 2011. Dissertação (Mestrado) - Faculdade de Medicina Veterinária e Zootecnia, Universidade de São Paulo, 2011.

BATISTA, C. F.; BLAGITZ, M. G.; AZEDO, M. R.; DELLA LIBERA, A. M. M. P. Doença Respiratória Dos Bezerros. Nosso Clínico, v. 3, n. 13, p. 4-10, 2010.

BATISTA, C. F.; BLAGITZ, M. G.; AZEDO, M. R.; STRICAGNOLO, C. R.; DELLA LIBERA, A. M. M. P. Efeito de medicamentos indicados para o tratamento de mastite bovina no período seco sobre os índices de fagocitose. Ciência Animal Brasileira, v. 10, n. 2, p. 574-580, 2009.

BATISTA, C. F.; BLAGITZ, M. G.; SANTOS, B. P.; BERTAGNON, H. G.; PARRA, A. C.; VIANNA, R. S.; DE LUCCA, G. G.; LIMA, D. M.; SANTOS, D. S.; DELLA LIBERA, A. M. M. P. Maturation of mononuclear phagocytes in the lungs of young calves--in vitro study. Journal of Dairy Science, v. 95, n. 10, p. 5909-15, out. 2012.

BEDNAREK, D.; KONDRACKI, M.; NIEMCZUK, K. Phenotypic analysis of peripheral blood leukocytes in respiratory diseased calves. Bulletin of the Veterinary Institute in Pulawy, v. 45, n. 2, p. 235-241, 2001.

BEDNAREK, D.; LUTNICKI, K.; DUDEK, K.; MARCZUK, J.; KUREK, L.; MORDAK, R.; STEWART, P. A. The effect of the combined use of a long-acting antibiotic with NSAID on the clinical status and cellular immune response in calves affected with bovine respiratory disease. Cattle Practice, v. 21, n. PART1, p. 91-97, 2013.

BELLINAZZI, J. B.; BERTAGNON, H. G.; BATISTA, C. F.; SANTOS, B. P.; LIMA, D. M.; LIMA, M. G. B.; BENESI, F. J.; DELLA LIBERA, A. M. M. P. Efeitos do estresse da orquiectomia na citologia broncoalveolar de bezerros da raça Holandesa. Pesquisa

Veterinária Brasileira, v. 33, n. supl 1, p. 93-98, 2013.

BENESI, F. J. Síndrome asfixia neonatal dos bezerros. Arquivos da Escola de Medicina Veterinária da Universidade Federal da Bahia, v. 16, p. 38-48, 1993.

BENESI, F. J. Diarréia infecciosa neonatal dos bezerros. In: SIMPÓSIO PFIZER SOBRE DOENÇAS INFECCIOSAS E VACINAS PARA BOVINOS, São Paulo. Anais... São Paulo: 1996.

BENESI, F. J.; BERTAGNON, H. G.; WACHHOLZ, L.; LEAL, M. L. R.; FERNANDES, W. R.; BENITES, N. R.; MELVILLE, P. A. Microbiota bacteriana e citologia da região traqueobrônquica de bezerros no período neonatal. Pesquisa Veterinária Brasileira, v. 33, n. 6, p. 700-704, jun. 2013.

BENESI, F. J.; WACHHOLZ, L.; BERTAGNON, H. G.; LEAL, M. L. R.; MORI, E.; FERNANDES, W. R. Citologia dos lavados traqueobrônquico (LTB) e broncoalveolar (LBA) de bezerros holandeses sadios durante o primeiro mês de vida. Pesquisa Veterinária Brasileira, v. 32, n. 3, p. 267-270, mar. 2012.

BIRGEL, E. H. Hematologia Clínica Veterinária. In: BIRGEL, E. H.; BENESI, F. J. (Ed.). Patologia Clínica Veterinária. 1. ed. São Paulo: Sociedade Paulista de Medicina Veterinária, 1982. p. 2-49. 
BLAGITZ, M. G. Avaliação funcional dos fagócitos sanguíneos e lácteos de vacas naturalmente infectadas pelo vírus da leucose dos bovinos. 2011. Tese (Doutorado) Faculdade de Medicina Veterinária e Zootecnia, Universidade de São Paulo, 2011.

BLAGITZ, M. G.; SOUZA, F. N.; GOMES, V.; DELLA LIBERA, A. M. M. P. Apoptosis and necrosis of polymorphonuclear leukocytes in goat milk with high and low somatic cell counts. Small Ruminant Research, v. 100, n. 1, p. 67-71, set. 2011.

BLONDEAU, J. M. Expanded activity and utility of the new fluoroquinolones: a review. Clinical Therapeutics, v. 21, n. 1, p. 3-40; discussion 1-2, jan. 1999.

BRITTON, A. P.; ZABEK, E. N. Bronchopneumonia in two dairy calves associated with Mannheimia species cluster V infection. Journal of Veterinary Diagnostic Investigation, v. 24, n. 6, p. 1043-6, nov. 2012.

BRODERSEN, B. W. Bovine respiratory syncytial virus. The Veterinary Clinics of North America. Food Animal Practice, v. 26, n. 2, p. 323-33, jul. 2010.

BROGDEN, K. A.; ACKERMANN, M. R.; DEBEY, B. M. Pasteurella haemolytica lipopolysaccharide-associated protein induces pulmonary inflammation after bronchoscopic deposition in calves and sheep. Infection and Immunity, v. 63, n. 9, p. 3595-3599, 1995.

BROWN, S. A. Fluoroquinolones in animal health. Journal of Veterinary Pharmacology and Therapeutics, v. 19, n. 1, p. 1-14, fev. 1996.

BRSCIC, M.; LERUSTE, H.; HEUTINCK, L. F. M.; BOKKERS, E. A. M.; WOLTHUISFILLERUP, M.; STOCKHOFE, N.; GOTTARDO, F.; LENSINK, B. J.; COZZI, G.; VAN REENEN, C. G. Prevalence of respiratory disorders in veal calves and potential risk factors. Journal of Dairy Science, v. 95, n. 5, p. 2753-2764, maio 2012.

BURTON, J. L.; MADSEN, S. A.; CHANG, L.-C.; WEBER, P. S. D.; BUCKHAM, K. R.; VAN DORP, R.; HICKEY, M.-C.; EARLEY, B. Gene expression signatures in neutrophils exposed to glucocorticoids: a new paradigm to help explain "neutrophil dysfunction" in parturient dairy cows. Veterinary Immunology and Immunopathology, v. 105, n. 3-4, p. 197-219, 15 maio 2005.

CASAL, R. F.; OST, D. E.; EAPEN, G. A. Flexible bronchoscopy. Clinics in Chest Medicine, v. 34, n. 3, p. 341-52, set. 2013.

CASWELL, J. L. Failure of Respiratory Defenses in the Pathogenesis of Bacterial Pneumonia of Cattle. Veterinary Pathology, v. 51, n. 2, p. 393-409, 10 set. 2014.

CASWELL, J. L.; BATEMAN, K. G.; CAI, H. Y.; CASTILLO-ALCALA, F. Mycoplasma bovis in respiratory disease of feedlot cattle. The Veterinary Clinics of North America.

Food Animal Practice, v. 26, n. 2, p. 365-79, jul. 2010.

CAVERLY, J. M.; ANDREASEN, C. B.; DIXON, R. A.; BROGDEN, K. A. Comparison of bronchoalveolar lavage fluid obtained from Mannheimia haemolytica- inoculated calves with and without prior treatment with the selectin inhibitor TBC1269. American Journal of Veterinary Research, v. 62, n. 5, p. 665-672, 2001.

CHEN, T. Y.; LEI, M. G.; SUZUKI, T.; MORRISON, D. C. Lipopolysaccharide receptors and signal transduction pathways in mononuclear phagocytes. Current Topics in Microbiology and Immunology, v. 181, p. 169-188, 1992. 
CHIN, A. C.; LEE, W. D.; MURRIN, K. A.; MORCK, D. W.; MERRILL, J. K.; DICK, P.; BURET, A. G. Tilmicosin Induces Apoptosis in Bovine Peripheral Neutrophils in the Presence or in the Absence of Pasteurella haemolytica and Promotes Neutrophil Phagocytosis by Macrophages. Antimicrobial Agents and Chemotherapy, v. 44, n. 9, p. 2465-2470, 1 set. 2000 .

CHO, Y. S.; PARK, S. Y.; SHIN, H. S.; CHAN, F. K.-M. Physiological consequences of programmed necrosis, an alternative form of cell demise. Molecules and Cells, v. 29, n. 4, p. 327-32, abr. 2010.

CONFER, A. W.; AYALEW, S.; STEP, D. L.; TROJAN, B.; MONTELONGO, M. Intranasal vaccination of young Holstein calves with Mannheimia haemolytica chimeric protein PlpELKT (SAC89) and cholera toxin. Veterinary Immunology and Immunopathology, v. 132, n. 2-4, p. 232-6, 15 dez. 2009.

CONFER, A. W.; SIMONS, K. R. Effects of Pasteurella haemolytica lipopolysaccharide on selected functions of bovine leukocytes. American Journal of Veterinary Research, v. 47, n. 1, p. 154-157, 1986.

COOPER, V. L.; BRODERSEN, B. W. Respiratory disease diagnostics of cattle. The Veterinary Clinics of North America. Food Animal Practice, v. 26, n. 2, p. 409-16, jul. 2010.

CORTESE, V. Neonatal Immunology. Veterinary Clinics of North America: Food Animal Practice, v. 25, n. 1, p. 221-227, 2009.

COUTINHO, A. D. S.; PAES, J.; FILHO, D. O.; PESSOA, D.; SILVA, G.; OLIVEIRA, A. P. De; MARCONDES, J. S.; CHIACCHIO, S. B.; PAES, A. C.; SIQUEIRA, A. K.; MARTINS, R.; CALDERON, R.; CHIACCHIO, S. B.; PAES, A. C.; AMORIM, R. M.;

EXPERIMENTAL, G. R. C. Mannheimiose pulmonar experimental em bezerros : swab nasal e nasofaringeano como auxílio diagnóstico. Pesquisa Veterinária Brasileira, v. 29, n. 1, p. 83-88, 2009.

CRADDICK, M.; PATEL, R.; LOWER, A.; HIGHLANDER, S.; ACKERMANN, M.; MCCLENAHAN, D. Adenosine-5'-triphosphate release by Mannheimia haemolytica, lipopolysaccharide, and interleukin-1 stimulated bovine pulmonary epithelial cells.

Veterinary Immunology and Immunopathology, v. 149, n. 1-2, p. 58-65, 15 set. 2012.

CZUPRYNSKI, C. J.; NOEL, E. J.; ADLAM, C. Pasteurella haemolytica A1 purified capsular polysaccharide does not stimulate interleukin-1 and tumor necrosis factor release by bovine monocytes and alveolar macrophages. Veterinary Immunology and

Immunopathology, v. 28, n. 2, p. 157-163, abr. 1991.

DARZYNKIEWICZ, Z.; BRUNO, S.; DEL BINO, G.; GORCZYCA, W.; HOTZ, M. A.; LASSOTA, P.; TRAGANOS, F. Features of apoptotic cells measured by flow cytometry. Cytometry, v. 13, n. 8, p. 795-808, 1992.

DE LA MORA, A.; TRIGO, F.; JARAMILLO, L.; GARFIAS, Y.; SOLÓRZANO, C.; AGUNDIS, C.; PEREYRA, A.; LASCURAIN, R.; ZENTENO, E.; SUÁREZ-GÜEMES, F. The N-acetyl-d-glucosamine specific adhesin from Mannheimia haemolytica activates bovine neutrophils oxidative burst. Veterinary Immunology and Immunopathology, v. 113, n. 1-2, p. 148-156, 2006. 
DELLA LIBERA, A. M. M. P.; DE SOUZA, F. N.; BATISTA, C. F.; SANTOS, B. P.; DE AZEVEDO, L. F. F.; SANCHEZ, E. M. R.; DINIZ, S. A.; SILVA, M. X.; HADDAD, J. P.; BLAGITZ, M. G. Effects of bovine leukemia virus infection on milk neutrophil function and the milk lymphocyte profile. Veterinary Research, 2015.

DENG, X.; LI, H.; TANG, Y. W. Cytokine expression in respiratory syncytial virus-infected mice as measured by quantitative reverse-transcriptase PCR. Journal of Virological Methods, v. 107, n. 2, p. 141-6, fev. 2003.

DIEZ-FRAILE, A.; MEYER, E.; PAAPE, M. J.; BURVENICH, C. Analysis of selective mobilization of L-selectin and Mac-1 reservoirs in bovine neutrophils and eosinophils.

Veterinary Research, v. 34, n. 1, p. 57-70, 2003.

DIONÍSIO, J. Diagnostic flexible bronchoscopy and accessory techniques. Revista Portuguesa de Pneumologia, v. 18, n. 2, p. 99-106, jan. 2012.

DIRKSEN, G.; GRUNDER, H. D.; STOBER, M. Rosenberger: exame clínico dos bovinos. 3. ed. Rio de Janeiro: Guanabara Koogan, 1993.

DOOMS, C.; SEIJO, L.; GASPARINI, S.; TRISOLINI, R.; NINANE, V.; TOURNOY, K. G. Diagnostic bronchoscopy: state of the art. European Respiratory Review, v. 19, n. 117, p. 229-36, set. 2010.

DOSOGNE, H.; HOEBEN, D.; BURVENICH, C.; LOHUIS, J. A. Effect of cephapirin and mecillinam on the phagocytic and respiratory burst activity of neutrophil leukocytes isolated from bovine blood. Journal of Veterinary Pharmacology and Therapeutics, v. 21, n. 6, p. 421-7, dez. 1998.

DU PREEZ, J. C.; VAN RENSBURG, E.; KILIAN, S. G. Kinetics of growth and leukotoxin production by Mannheimia haemolytica in continuous culture. Journal of Industrial Microbiology \& Biotechnology, v. 35, n. 6, p. 611-8, jun. 2008.

ENELOW, R. I.; MOHAMMED, a Z.; STOLER, M. H.; LIU, a N.; YOUNG, J. S.; LOU, Y. H.; BRACIALE, T. J. Structural and functional consequences of alveolar cell recognition by CD8(+) T lymphocytes in experimental lung disease. The Journal of Clinical Investigation, v. 102, n. 9, p. 1653-1661, 1998.

FAGLIARI, J. J. Estudo clínico e laboratorial da pneumonia de bezerros induzida pela inoculação intrabronquial de Mannheimia haemolytica. Arquivo Brasileiro de Medicina Veterinária e Zootecnia, v. 55, n. 1, p. 8-14, fev. 2003.

FERRI, L. E.; CHIA, S.; BENAY, C.; GIANNIAS, B.; CHRISTOU, N. V. L-selectin shedding in sepsis limits leukocyte mediated microvascular injury at remote sites. Surgery, v. 145 , n. 4, p. 384-391, 2009.

FISCHER, C. D.; BEATTY, J. K.; DUQUETTE, S. C.; MORCK, D. W.; LUCAS, M. J.; BURET, A. G. Direct and indirect anti-inflammatory effects of tulathromycin in bovine macrophages: inhibition of CXCL-8 secretion, induction of apoptosis, and promotion of efferocytosis. Antimicrobial Agents and Chemotherapy, v. 57, n. 3, p. 1385-93, 1 mar. 2013.

FISCHER, C. D.; BEATTY, J. K.; ZVAIGZNE, C. G.; MORCK, D. W.; LUCAS, M. J.; BURET, A. G. Anti-Inflammatory benefits of antibiotic-induced neutrophil apoptosis: 
tulathromycin induces caspase-3-dependent neutrophil programmed cell death and inhibits NF-kappaB signaling and CXCL8 transcription. Antimicrobial Agents and Chemotherapy, v. 55 , n. 1 , p. $338-48,1$ jan. 2011.

FOX, S.; LEITCH, A. E.; DUFFIN, R.; HASLETT, C.; ROSSI, A. G. Neutrophil apoptosis: Relevance to the innate immune response and inflammatory disease. Journal of Innate Immunity, v. 2, n. 3, p. 216-227, 2010.

GARN, H. Specific aspects of flow cytometric analysis of cells from the lung. Experimental and Toxicologic Pathology, v. 57 Suppl 2, p. 21-4, jun. 2006.

GATEWOOD, D. M.; FENWICK, B. W.; CHENGAPPA, M. M. Growth-condition dependent expression of Pasteurella haemolytica A1 outer membrane proteins, capsule, and leukotoxin. Veterinary Microbiology, v. 41, n. 3, p. 221-33, 1 ago. 1994.

GIPS, M.; SOBACK, S. Norfloxacin nicotinate pharmacokinetics in unwearied and weaned calves. Journal of Veterinary Pharmacology and Therapeutics, v. 19, n. 2, p. 130-134, abr. 1996.

GODINHO, K. S.; SARASOLA, P.; RENOULT, E.; TILT, N.; KEANE, S.; WINDSOR, G. D.; ROWAN, T. G.; SUNDERLAND, S. J. Use of deep nasopharyngeal swabs as a predictive diagnostic method for natural respiratory infections in calves. The Veterinary Record, v. 160, n. 1, p. 22-25, 2007.

GOLSTEIN, P.; KROEMER, G. Cell death by necrosis: towards a molecular definition. Trends in Biochemical Sciences, v. 32, n. 1, p. 37-43, 2007.

GONÇALVES, R. C. Estudo clínico e citológico em bezerros clinicamente sadios e portadores de broncopneumonia moderada e grave: o lavado traqueobrônquico como complemento diagnóstico. 1997. Tese (Doutorado em Patologia) - Faculdade de Medicina Veterinária e Zootecnia, Universidade Estadual Paulista Júlio Mesquita Filho, Botucatu, 1997.

GONÇALVES, R. C.; FEITOSA, F. L. F. Semiologia do sistema respiratório de grandes animais. In: FEITOSA, F. L. F. . (Ed.). Semiologia Veterinária: a arte do diagnóstico. $2^{\mathrm{a}}$. ed. São Paulo: Roca, 2008. p. 275-306.

GONÇALVES, R. C.; LISBÔA, J. A. N.; SOUSA, M. V. de; ALMEIDA, C. T. de; KUCHEMBUCK, M. R. G.; CHIACCHIO, S. B. Aspectos clínicos e epidemiológicos da broncopneumonia dos bezerros em Botucatu, SP. Revista Brasileira de Ciência Veterinária, v. 7, n. 3, p. $144-147,2000$.

GONÇALVES, R. C.; LISBOA, J. A. N.; SOUZA, M. V.; ALMEIDA, C. T.; KUCHEMBUCK, M. R. G. Doenças de bezerro. Pneumonia. Aspectos clínicos e epidemiológicos na região de Botucatu. In: Anais do Congresso Internacional de Medicina Veterinária em Língua Portuguesa, Salvador. Anais... Salvador: 1993.

GONÇALVES, R. C.; MATTOS, M. C. F. I.; KUCHEMBUCK, M. R. G.; LOPES, R. S.; BORGES, A. S. Lavagem traqueobrônquica por sondagem nasotraqueal em bezerros. Arquivo Brasileiro de Medicina Veterinária e Zootecnia, v. 56, n. 3, p. 307-311, jun. 2004. 
GONZÁLEZ-CANO, P.; ARSIC, N.; POPOWYCH, Y. I.; GRIEBEL, P. J. Two functionally distinct myeloid dendritic cell subpopulations are present in bovine blood. Developmental and Comparative Immunology, v. 44, n. 2, p. 378-88, jun. 2014.

GORDEN, P. J.; PLUMMER, P. Control, management, and prevention of bovine respiratory disease in dairy calves and cows. The Veterinary Clinics of North America. Food Animal Practice, v. 26, n. 2, p. 243-59, jul. 2010.

GRELL, S. N.; RIBER, U.; TJØRNEHØJ, K.; LARSEN, L. E.; HEEGAARD, P. M. H. Agedependent differences in cytokine and antibody responses after experimental RSV infection in a bovine model. Vaccine, v. 23, n. 26, p. 3412-23, 16 maio 2005a.

GRELL, S. N.; TJØRNEHØJ, K.; LARSEN, L. E.; HEEGAARD, P. M. H. Marked induction of IL-6, haptoglobin and IFNgamma following experimental BRSV infection in young calves. Veterinary Immunology and Immunopathology, v. 103, n. 3-4, p. 235-45, 10 fev. 2005b.

GRIFFIN, D. Bovine pasteurellosis and other bacterial infections of the respiratory tract. The Veterinary Clinics of North America. Food Animal Practice, v. 26, n. 1, p. 57-71, table of contents, mar. 2010.

GRIFFIN, D.; CHENGAPPA, M. M.; KUSZAK, J.; MCVEY, D. S. Bacterial pathogens of the bovine respiratory disease complex. The Veterinary Clinics of North America. Food Animal Practice, v. 26, n. 2, p. 381-94, jul. 2010.

HANZLICEK, G. A.; WHITE, B. J.; MOSIER, D.; RENTER, D. G.; ANDERSON, D. E. Serial evaluation of physiologic, pathological, and behavioral changes related to disease progression of experimentally induced Mannheimia haemolytica pneumonia in postweaned calves. American Journal of Veterinary Research, v. 71, n. 3, p. 359-369, mar. 2010.

HASUI, M.; HIRABAYASHI, Y.; KOBAYASHI, Y. Simultaneous measurement by flow cytometry of phagocytosis and hydrogen peroxide production of neutrophils in whole blood. Journal of Immunological Methods, v. 117, n. 1, p. 53-8, 8 fev. 1989.

HEARST, J. E.; WARR, G. A.; JAKAB, G. J. Characterization of murine lung and peritoneal macrophages. RES Journal of the Reticuloendothelial Society, v. 27, n. 5, p. 443-454, 1980.

HERMEYER, K.; BUCHENAU, I.; THOMASMEYER, A.; BAUM, B.; SPERGSER, J.; ROSENGARTEN, R.; HEWICKER-TRAUTWEIN, M. Chronic pneumonia in calves after experimental infection with Mycoplasma bovis strain 1067: characterization of lung pathology, persistence of variable surface protein antigens and local immune response. Acta Veterinaria Scandinavica, v. 54, n. 1, p. 9, jan. 2012.

HILDING, A. C. Experimental bronchoscopy: resultant trauma to tracheobronchial epithelium in calves from routine inspection. Transactions - American Academy of Ophthalmology and Otolaryngology., v. 72, n. 4, p. 604-13, jan. 1968.

HOEBEN, D.; DOSOGNE, H.; HEYNEMAN, R.; BURVENICH, C. Effect of antibiotics on the phagocytotic and respiratory burst activity of bovine granulocytes. European Journal of Pharmacology, v. 332, n. 3, p. 289-297, ago. 1997. 
HOLMES, W. E.; LEE, J.; KUANG, W. J.; RICE, G. C.; WOOD, W. I. Structure and functional expression of a human interleukin-8 receptor. Science (New York, N.Y.), v. 253, n. 5025 , p. $1278-80,13$ set. 1991.

HOLMGREN, S.; HAGBERG GUSTAVSSON, M.; LUNDÉN, A.; WATTRANG, E. Cytokine mRNA expression in bronchoalveolar lavage cells during Dictyocaulus viviparus infection in calves. Parasite Immunology, v. 36, n. 2, p. 78-86, fev. 2014.

HOTCHKISS, E. J.; DAGLEISH, M. P.; WILLOUGHBY, K.; MCKENDRICK, I. J.; FINLAYSON, J.; ZADOKS, R. N.; NEWSOME, E.; BRULISAUER, F.; GUNN, G. J.; HODGSON, J. C. Prevalence of Pasteurella Multocida and Other Respiratory Pathogens in the Nasal Tract of Scottish Calves. The Veterinary Record, v. 167, n. 15, p. 555-560, 9 out. 2010 .

IBGE. INSTITUTO BRASILEIRO DE GEOGRAFIA E ESTATÍSTICA. Indicadores do IBGE: estatística da produção pecuária. 2015.Brasilia, 2015. .

ILLAMBAS, J.; POTTER, T.; SIDHU, P.; RYCROFT, a N.; CHENG, Z.; LEES, P. Pharmacodynamics of florfenicol for calf pneumonia pathogens. The Veterinary Record, $v$. 172 , n. 13, p. 340-345, 30 mar. 2013.

INGALE, S. L.; SINGH, P.; RAINA, O. K.; MEHRA, U. R.; VERMA, A. K.; GUPTA, S. C.; MULIK, S. V. Interferon-gamma and interleukin-4 expression during Fasciola gigantica primary infection in crossbred bovine calves as determined by real -time PCR. Veterinary Parasitology, v. 152, n. 1-2, p. 158-61, 25 mar. 2008.

IOVANE, G.; GALDIERO, M.; VITIELLO, M.; DE MARTINO, L. Effect of Pasteurella haemolytica outer membrane proteins on bovine neutrophils. FEMS Immunology and Medical Microbiology, v. 20, n. 1, p. 29-36, 1998.

IRSIK, M. Bovine Respiratory Disease Associated with Mannheimia Haemolytica or Pasteurella Multocida. Veterinary Medicine-Large Animal Clinical Sciences Department, v. 163 , p. 2-4, 2010.

JARAMILLO-ARANGO, C. J.; TAVERA, F. J. T.; SUÁREZ-GÜEMES, F. Mannheimiosis bovina: etiología, prevención y control Bovine mannheimiosis: etiology, prevention and control. Veterinaria México, v. 40, n. 3, p. 293-314, 2009.

JONES, C.; CHOWDHURY, S. Bovine herpesvirus type 1 (BHV-1) is an important cofactor in the bovine respiratory disease complex. The Veterinary Clinics of North America. Food Animal Practice, v. 26, n. 2, p. 303-21, jul. 2010.

JUNGI, T. W.; SAGER, H.; ADLER, H.; BRCIC, M.; PFISTER, H. Serum factors, cell membrane $\mathrm{CD} 14$, and $\beta 2$ integrins are not required for activation of bovine macrophages by lipopolysaccharide. Infection and Immunity, v. 65, n. 9, p. 3577-3584, 1997.

KABARA, E.; SORDILLO, L. M.; HOLCOMBE, S.; CONTRERAS, G. A. Adiponectin links adipose tissue function and monocyte inflammatory responses during bovine metabolic stress. Comparative Immunology, Microbiology and Infectious Diseases, v. 37, n. 1, p. 49-58, jan. 2014.

KAMPEN, A. H.; TOLLERSRUD, T.; LARSEN, S.; ROTH, J. A.; FRANK, D. E.; LUND, A. Repeatability of flow cytometric and classical measurement of phagocytosis and 
respiratory burst in bovine polymorphonuclear leukocytes. Veterinary Immunology and Immunopathology, v. 97, n. 1-2, p. 105-114, jan. 2004.

KATSUDA, K.; KAMIYAMA, M.; KOHMOTO, M.; KAWASHIMA, K.; TSUNEMITSU, H.; EGUCHI, M. Serotyping of Mannheimia haemolytica isolates from bovine pneumonia: 1987-2006. Veterinary Journal, v. 178, n. 1, p. 146-8, out. 2008.

KERR, J. F. R.; WYLLIE, A. H.; CURRIE, A. R. Apoptosis: A basic biological phenomenon with wide-ranging implications in human disease. British Journal of Cancer, v. 26, p. 239257, 1972.

KHADOM, N. J.; DEDIEU, J. F.; VISO, M. Bovine alveolar macrophage: a review. Annales de Recherches Veterinaires, v. 16, n. 3, p. 175-183, 1985.

KIM, J. J.; LEE, S. B.; PARK, J. K.; YOO, Y. D. TNF-alpha-induced ROS production triggering apoptosis is directly linked to Romol and $\mathrm{Bcl}-\mathrm{X}(\mathrm{L})$. Cell Death and

Differentiation, v. 17, n. 9, p. 1420-1434, 2010.

KLEBANOFF, S. J. Oxygen metabolism and the toxic properties of phagocytes. Annals of Internal Medicine, v. 93, n. 3, p. 480-9, set. 1980.

KOBAYASHI, S. D.; VOYICH, J. M.; DELEO, F. R. Regulation of the neutrophil-mediated inflammatory response to infection. Microbes and Infection, v. 5, n. 14, p. 1337-1344, 2003.

KOESS, C.; HAMANN, J. Detection of mastitis in the bovine mammary gland by flow cytometry at early stages. The Journal of dairy research, v. 75, n. 2, p. 225-232, 2008.

KOTERBA, A. M. Identificação do neonato de alto risco. Distúrbios e tratamento do neonato. In: SMITH B.P (Ed.). Tratado de Medicina Interna de Grandes Animais. 1. ed. São Paulo: Manole, 1993. p. 299-301.

KROEMER, G.; GALLUZZI, L.; VANDENABEELE, P.; ABRAMS, J.; ALNEMRI, E. S.; BAEHRECKE, E. H.; BLAGOSKLONNY, M. V; EL-DEIRY, W. S.; GOLSTEIN, P.; GREEN, D. R.; HENGARTNER, M.; KNIGHT, R. A.; KUMAR, S.; LIPTON, S. A.; MALORNI, W.; NUÑEZ, G.; PETER, M. E.; TSCHOPP, J.; YUAN, J.; PIACENTINI, M.; ZHIVOTOVSKY, B.; MELINO, G. Classification of cell death: recommendations of the Nomenclature Committee on Cell Death 2009. Cell Death and Differentiation, v. 16, n. 1, p. 3-11, 10 jan. 2009.

KRYSKO, D. V; VANDEN BERGHE, T.; D’HERDE, K.; VANDENABEELE, P. Apoptosis and necrosis: detection, discrimination and phagocytosis. Methods, v. 44, n. 3, p. 205-21, mar. 2008.

KUNKEL, S. L.; STANDIFORD, T.; KASAHARA, K.; STRIETER, R. M. Interleukin-8 (IL8): The Major Neutrophil Chemotactic Factor in the Lung. Experimental Lung Research, v. 17, p. 17-23, 2 jul. 1991.

LEACH, R. J.; O’NEILL, R. G.; FITZPATRICK, J. L.; WILLIAMS, J. L.; GLASS, E. J. Quantitative trait loci associated with the immune response to a bovine respiratory syncytial virus vaccine. PloS One, v. 7, n. 3, p. e33526, jan. 2012.

LEE, W. D.; FLYNN, A. N.; LEBLANC, J. M.; MERRILL, J. K.; DICK, P.; MORCK, D. W.; BURET, A. G. Tilmicosin-Induced Bovine Neutrophil Apoptosis Is Cell-Specific and 
Downregulates Spontaneous LTB4 Synthesis without Increasing Fas Expression. Veterinary Research, v. 35, n. 2, p. 213-24, 1 jan. 2004.

LEITE, F.; O’BRIEN, S.; SYLTE, M. J.; PAGE, T.; ATAPATTU, D.; CZUPRYNSKI, C. J. Inflammatory Cytokines Enhance the Interaction of Mannheimia haemolytica Leukotoxin with Bovine Peripheral Blood Neutrophils In Vitro. Infection and Immunity, v. 70, n. 8, p. 4336-4343, 1 ago. 2002.

LERUSTE, H.; BRSCIC, M.; HEUTINCK, L. F. M.; VISSER, E. K.; WOLTHUISFILLERUP, M.; BOKKERS, E. A. M.; STOCKHOFE-ZURWIEDEN, N.; COZZI, G.; GOTTARDO, F.; LENSINK, B. J.; VAN REENEN, C. G. The relationship between clinical signs of respiratory system disorders and lung lesions at slaughter in veal calves. Preventive Veterinary Medicine, v. 105, n. 1-2, p. 93-100, 1 jun. 2012.

LOHMANN-MATTHES, M. L.; STEINMÜLLER, C.; FRANKE-ULLMANN, G. Pulmonary macrophages. European Respiratory Journal, v. 7, n. 9, p. 1678-1689, 1 set. 1994.

LOHMEYER, J.; FRIEDRICH, J.; ROSSEAU, S.; PRALLE, H.; SEEGER, W. Multiparameter flow cytometric analysis of inflammatory cells contained in bronchoalveolar lavage fluid. Journal of Immunological Methods, v. 172, n. 1, p. 59-70, jun. 1994.

LORENZ, I.; EARLEY, B.; GILMORE, J.; HOGAN, I.; KENNEDY, E.; MORE, S. J. Calf Health from Birth to Weaning. III. Housing and Management of Calf Pneumonia. Irish Veterinary Journal, v. 64, n. 1, p. 14, 21 jan. 2011.

LOVE, W. J.; LEHENBAUER, T. W.; KASS, P. H.; VAN EENENNAAM, A. L.; ALY, S. S. Development of a novel clinical scoring system for on-farm diagnosis of bovine respiratory disease in pre-weaned dairy calves. PeerJ, v. 2, p. e238, jan. 2014.

MALAZDREWICH, C.; AMES, T. R.; ABRAHAMSEN, M. S.; MAHESWARAN, S. K. Pulmonary expression of tumor necrosis factor alpha, interleukin-1 beta, and interleukin- 8 in the acute phase of bovine pneumonic pasteurellosis. Veterinary Pathology, v. 38, n. 3, p. 297-310, 1 maio 2001.

MALAZDREWICH, C.; THUMBIKAT, P.; ABRAHAMSEN, M. .; MAHESWARAN, S. . Pharmacological inhibition of Mannheimia haemolytica lipopolysaccharide and leukotoxininduced cytokine expression in bovine alveolar macrophages. Microbial Pathogenesis, v. 36, n. 3, p. 159-169, mar. 2004.

MANDIL, R.; PANGHAL, R. S.; KUMAR, V.; RANA, R. D. Pharmacokinetics of norfloxacin in buffalo calves. Indian Veterinary Journal, v. 87, n. 3, p. 240-243, 2010.

MAŚLANKA, T.; JAROSZEWSKI, J. J.; MARKIEWICZ, W.; JAKUBOWSKI, P. Evaluation of the influence of meloxicam and flunixin meglumine on the apoptosis of peripheral blood CD4+ and CD8+ T cells in calves. Polish Journal of Veterinary Sciences, v. 13, n. 1 , p. $3-12,2010$.

MATHY, N. L.; MATHY, J.-P. D.; LEE, R. P.; WALKER, J.; LOFTHOUSE, S.; MEEUSEN, E. N. T. Pathological and immunological changes after challenge infection with Pasteurella multocida in naive and immunized calves. Veterinary Immunology and Immunopathology, v. 85, n. 3-4, p. 179-188, mar. 2002. 
MCCLENAHAN, D. J.; FAGLIARI, J. J.; EVANSON, O. A.; WEISS, D. J. Evaluation of structural and functional alterations of circulating neutrophils in calves with experimentally induced pneumonic pasteurellosis. American Journal of Veterinary Research, v. 60, n. 10, p. 1307-1311, 1999.

MCGUIRK, S. M. Disease Management of Dairy Calves and Heifers. Veterinary Clinics of North America - Food Animal Practice, v. 24, n. 1, p. 139-153, 2008.

MCINNES, E.; SOPP, P.; HOWARD, C. J.; TAYLOR, G. Phenotypic analysis of local cellular responses in calves infected with bovine respiratory syncytial virus. Immunology, v. 96, n. 3, p. 396-403, 1999.

MENA, A.; IOANNOU, X. P.; VAN KESSEL, A.; VAN DRUNEN LITTLE-VAN DEN HURK, S.; POPOWYCH, Y.; BABIUK, L. A.; GODSON, D. L. Th1/Th2 biasing effects of vaccination in cattle as determined by real-time PCR. Journal of Immunological Methods, v. 263, n. 1-2, p. 11-21, 1 maio 2002.

MITCHELL, G. B.; ALBRIGHT, B. N.; CASWELL, J. L. Effect of Interleukin-8 and Granulocyte Colony-Stimulating Factor on Priming and Activation of Bovine Neutrophils. Infection and Immunity, v. 71, n. 4, p. 1643-1649, 1 abr. 2003.

MORSEY, M. A.; VAN-KESSEL, A. G.; MORI, Y.; POPOWYCH, Y.; GODSON, D.; CAMPOS, M.; BABIUK, L. A. Cytokine profiles following interaction between bovine alveolar macrophages and Pasteurella haemolytica. Microbial Pathogenesis, v. 26, n. 6, p. 325-31, jun. 1999.

MURPHY, K. Conceitos Básicos em Imunologia. In: MURPHY, K. (Ed.). Imunobiologia de Janeway. $8^{\mathrm{a}}$. ed. Porto Alegre: Artmed, 2014. p. 1-36.

MYRVIK, Q. N.; LEAKE, E. S.; FARISS, B. Lysozyme content of alveolar and peritoneal macrophages from the rabbit. Journal of Immunology, v. 86, p. 133-136, 1961.

NAUSEEF, W. M.; CLARK, R. . Granulocytic phagocytes. In: MANDELL, G. L.; BENNETT, J. E.; DOLIN, R. (Ed.). Mandell, Douglas, and Bennett's Principles and Practice of Infectious Diseases. 7. ed. Philadelphia: Churchill Livingstone, 2010.

OLIVEIRA, L. J.; MCCLELLAN, S.; HANSEN, P. J. Differentiation of the endometrial macrophage during pregnancy in the cow. PLoS ONE, v. 5, n. 10, 2010.

OLLIVETT, T. Understanding the diagnosis and risk factors for respiratory disease in dairy calves. 2014. Thesis (PhD) University of Guelph, 2014.

OZKANLAR, Y.; AKTAS, M. S.; KAYNAR, O.; OZKANLAR, S.; KIRECCI, E.; YILDIZ, L. Bovine respiratory disease in naturally infected calves: clinical signs, blood gases and cytokine response. Revue de Médicine Véterinaire, v. 163, n. 3, p. 123-130, 2012.

PAAPE, M. J.; BANNERMAN, D. D.; ZHAO, X.; LEE, J. W. The bovine neutrophil: Structure and function in blood and milk. Veterinary Research, v. 34, n. 5, p. 597-627, 2003.

PARDON, B.; ALLIËT, J.; BOONE, R.; ROELANDT, S.; VALGAEREN, B.; DEPREZ, P. Prediction of respiratory disease and diarrhea in veal calves based on immunoglobulin levels and the serostatus for respiratory pathogens measured at arrival. Preventive Veterinary Medicine, v. 120, n. 2, p. 169-176, 2015. 
PECK, A.; MELLINS, E. D. Precarious balance: Th17 cells in host defense. Infection and Immunity, v. 78, n. 1, p. 32-38, 2010.

PELLETIER, M.; MAGGI, L.; MICHELETTI, A.; LAZZERI, E.; TAMASSIA, N.; COSMI, L.; LUNARDI, C.; ANNUNZIATO, F.; ROMAGNANI, S.; MARCO, A.; DC, W.; COSTANTINI, C.; CASSATELLA, M. a. Evidence for a cross-talk between human neutrophils and Th17 cells. Blood, v. 115, n. 2, p. 335-343, 2010.

PEREIRA, M. S. V; SIQUEIRA, J. P.; CAMPOS TAKAKI, G. M. Eliminação de resistência a drogas por fluorquinolonas em Staphylococcus aureus de origem bovina. Pesquisa Veterinaria Brasileira, v. 24, n. 1, p. 11-14, 2004.

PERTICARARI, S.; PRESANI, G.; BANFI, E. A new flow cytometric assay for the evaluation of phagocytosis and the oxidative burst in whole blood. Journal of Immunological Methods, v. 170, n. 1, p. 117-24, 29 mar. 1994.

PESSOA, R. B.; BLAGITZ, M. G.; BATISTA, C. F.; SANTOS, B. P.; PARRA, A. C.; SOUZA, F. N. Avaliação da apoptose de leucócitos polimorfonucleares CH138+ em leite bovino de alta e baixa contagem de células somáticas - dados preliminares. Arquivos Brasileiros de Medicina Veterinária e Zootecnia, v. 64, n. 3, p. 533-539, 2012.

PETERSON, B. T.; IDELL, S.; MACARTHUR, C.; GRAY, L. D.; COHEN, A. B. A modified bronchoalveolar lavage procedure that allows measurement of lung epithelial lining fluid volume. The American Review of Respiratory Disease, v. 141, n. 2, p. 314-20, fev. 1990.

PFAFFL, M. W.; HORGAN, G. W.; DEMPFLE, L. Relative expression software tool (REST) for group-wise comparison and statistical analysis of relative expression results in real-time PCR. Nucleic Acids Research, v. 30, n. 9, p. e36, 1 maio 2002.

POTGIETER, L. N.; MCCRACKEN, M. D.; HOPKINS, F. M.; WALKER, R. D.; GUY, J. S. Use of fiberoptic bronchoscopy in experimental production of bovine respiratory tract disease. American Journal of Veterinary Research, v. 45, n. 5, p. 1015-9, maio 1984.

PROHL, A.; OSTERMANN, C.; LOHR, M.; REINHOLD, P. The Bovine Lung in Biomedical Research: Visually Guided Bronchoscopy, Intrabronchial Inoculation and In Vivo Sampling Techniques. Journal of Visualized Experiments, n. 89, p. 1-11, 2014.

RABELO, S. S. A.; LIMA JÚNIOR, A. D.; CASTRO, R. S.; TABOSA, J. H. C. Sazonalidade da broncopneumonia em bezerros da microrregi?o de Garanhuns, Pernambuco (1983-1991).

Arquivos Brasileiros de Medicina Veterinária e Zootecnia, v. 48, n. 1, p. 19-26, 1996.

RAIDAL, S. I.; BAILEY, G. D.; LOVE, D. N. The flow cytometric evaluation of phagocytosis by equine peripheral blood neutrophils and pulmonary alveolar macrophages. The Veterinary Journal, v. 156, n. 2, p. 107-116, set. 1998.

REZENDE, M. L. G. Avaliação de parâmetros clínicos, hematológicos e viabilidade econômica do uso do florfenicol na metafilaxia das afecções respiratórias inespecíficas de bovinos confinados no estado de goiás. 2010. Tese (Doutorado)- Escola de Veterinária, Universidade Federal de Goiás, 2010. 
RICE, J. A.; CARRASCO-MEDINA, L.; HODGINS, D. C.; SHEWEN, P. E. Mannheimia haemolytica and bovine respiratory disease. Animal Health Research Reviews, v. 8, n. 2, p. 117-28, dez. 2007.

RIDPATH, J. The contribution of infections with bovine viral diarrhea viruses to bovine respiratory disease. The Veterinary Clinics of North America. Food Animal Practice, v. 26, n. 2, p. 335-48, jul. 2010.

RINALDI, M.; MORONI, P.; PAAPE, M. J.; BANNERMAN, D. D. Differential alterations in the ability of bovine neutrophils to generate extracellular and intracellular reactive oxygen species during the periparturient period. Veterinary Journal, v. 178, n. 2, p. 208-213, 2008.

SALEH, G. A.; ASKAL, H. F.; REFAAT, I. H.; ABDEL-AAL, F. A. M. Review on recent separation methods for determination of some fluoroquinolones. Journal of Liquid Chromatography and Related Technologies, v. 36, n. 10, p. 1401-1420, 2013.

SAMPAIO, I. B. M. Estatística aplicada à experimentação animal. 1. ed. Belo Horizonte: Fundação de Ensino e Pesquisa em Medicina Veterinária e Zootecnia, 1998.

SATHIAMOORTHY, S.; SHEWEN, P. E.; HODGINS, D. C.; LO, R. Y. C. In vivo gene expression in Mannheimia haemolytica A1 during a time-course trial in the bovine host. Veterinary Microbiology, v. 158, n. 1-2, p. 163-71, 6 jul. 2012.

SAVILL, J.; DRANSFIELD, I.; GREGORY, C.; HASLETT, C. A blast from the past: clearance of apoptotic cells regulates immune responses. Nature Reviews. Immunology, v. 2, n. 12, p. 965-75, dez. 2002.

SEGAL, A. W. How neutrophils kill microbes. Annual Review of Immunology, v. 23, n. 2, p. 197-223, 2005.

SINGH, K.; CONFER, A. W.; STEP, D. L.; RIZZI, T.; WYCKOFF, J. H.; WENG, H.-Y.; RITCHEY, J. W. Cytokine expression by pulmonary leukocytes from calves challenged with wild-type and leukotoxin-deficient Mannheimia haemolytica. Veterinary Journal, v. 192, n. 1, p. 112-9, abr. 2012.

SINGH, K.; RITCHEY, J. W.; CONFER, A. W. Mannheimia haemolytica: bacterial-host interactions in bovine pneumonia. Veterinary Pathology, v. 48, n. 2, p. 338-48, mar. 2011.

SLÁDEK, Z.; RYŠÁNEK, D. Apoptosis of polymorphonuclear leukocytes of the juvenile bovine mammary gland during induced influx. Veterinary Research, v. 31, n. 6, p. 553-563, 2000.

SLÁDEK, Z.; RYŠÁNEK, D. Neutrophil apoptosis during the resolution of bovine mammary gland injury. Research in Veterinary Science, v. 70, n. 1, p. 41-46, 2001.

SLÁDEK, Z.; RYŠÁNEK, D. Apoptosis of resident and inflammatory macrophages before and during the inflammatory response of the virgin bovine mammary gland. Acta Veterinaria Scandinavica, v. 52, p. 12, 2010.

SLÁDEK, Z.; RYŠÁNEK, D. CD14 expression, apoptosis and necrosis in resident and inflammatory macrophages from virgin bovine mammary gland. Veterinarni Medicina, v. 59, n. 10, p. 467-478, 2014. 
SOETHOUT, E. C.; MÜLLER, K. E.; RUTTEN, V. P. M. G. Neutrophil migration in the lung, general and bovine-specific aspects. Veterinary Immunology and Immunopathology, v. 87, n. $3-4$, p. $277-85$, 10 set. 2002.

SOETHOUT, E. C.; MÜLLER, K. E.; VAN DEN BELT, A. J. M.; RUTTEN, V. P. M. G. Identification and Phenotyping of Leukocytes in Bovine Bronchoalveolar Lavage Fluid. Clinical and Diagnostic Laboratory Immunology, v. 11, n. 4, p. 795-8, 1 jul. 2004.

SWEENEY, C. R.; HUMBER, K. A.; ROBY, K. A. Cytologic findings of tracheobronchial aspirates from 66 thoroughbred racehorses. American Journal of Veterinary Research, v. 53, n. 7, p. 1172-1175, 1992.

TAYLOR, J. D.; HOLLAND, B. P.; STEP, D. L.; PAYTON, M. E.; CONFER, A. W. Nasal isolation of Mannheimia haemolytica and Pasteurella multocida as predictors of respiratory disease in shipped calves. Research in Veterinary Science, v. 99, p. 41-5, abr. 2015.

TESFAYE, B.; SISAY TESSEMA, T.; TEFERA, G. Diversity of bacterial species in the nasal cavity of sheep in the highlands of Ethiopia and first report of Histophilus somni in the country. Tropical Animal Health and Production, v. 45, n. 5, p. 1243-1249, 2013.

THIRY, J.; GONZÁLEZ-MARTÍN, J. V; ELVIRA, L.; PAGOT, E.; VOISIN, F.; LEQUEUX, G.; WEINGARTEN, A.; DE HAAS, V. Treatment of Naturally Occurring Bovine Respiratory Disease in Juvenile Calves with a Single Administration of a Florfenicol plus Flunixin Meglumine Formulation. The Veterinary Record, v. 174, n. 17, p. 430, 26 abr. 2014.

THORNBERRY, N. A. Caspases: key mediators of apoptosis. Chemistry \& Biology, v. 5, n. 5, p. R97-R103, maio 1998.

THRUNAVUKKARASU, P.; SENTHILKUMAR, G.; DHANAPALAN, P.; VASU, K. Bronchoscopic findings in bovine respiratory disorders. Indian Veterinary Journal, v. 82, p. 1206-1207, 2005.

THUMBIKAT, P.; DILEEPAN, T.; KANNAN, M. S.; MAHESWARAN, S. K. Mechanisms underlying Mannheimia haemolytica leukotoxin-induced oncosis and apoptosis of bovine alveolar macrophages. Microbial Pathogenesis, v. 38, n. 4, p. 161-72, abr. 2005.

TIZARD, I. R. Imunologia veterinária. 9. ed. Rio de Janeiro: Elsevier, 2014.

ULEVITCH, R. J.; TOBIAS, P. S. RECEPTOR-DEPENDENT MECHANISMS OF CELL STIMULATION BY BACTERIAL ENDOTOXIN. Annual Review of Immunology, v. 13, p. 437-457, 1995.

UNDERHILL, D. M.; OZINSKY, A. Phagocytosis of microbes: complexity in action. Annual Review of Immunology, v. 20, p. 825-52, jan. 2002.

VAN OOSTVELDT, K.; PAAPE, M. ,; DOSOGNE, H.; BURVENICH, C. Effect of apoptosis on phagocytosis, respiratory burst and CD18 adhesion receptor expression of bovine neutrophils. Domestic Animal Endocrinology, v. 22, n. 1, p. 37-50, mar. 2002.

VERMES, I.; HAANEN, C.; REUTELINGSPERGER, C. Flow cytometry of apoptotic cell death. Journal of Immunological Methods, v. 243, n. 1-2, p. 167-90, 21 set. 2000. 
VIJAN, L. E.; CONCI, M. Absorption Study of Norfloxacin - DNA Interaction. Macromolecular Symposia, v. 265, n. 1, p. 260-267, 2008.

WALLEMACQ, H.; RAMERY, E.; BUREAU, F.; LEKEUX, P. How transcriptomic studies may help to improve the control of bovine diseases: an example with calf pneumonia and endotoxemia. Hungarian Veterinary Journal, v. 130, n. Supll. 1, p. 75-77, 2008.

WESSELY-SZPONDER, J.; URBAN-CHMIEL, R.; WERNICKI, A.; BOBOWIEC, R. Effect of leukotoxin of Mannheimia haemolytica and LPS of E. coli on secretory response of bovine neutrophils in vitro. Polish Journal of Veterinary Sciences, v. 8, n. 2, p. 99-105, 2005.

WIKSE, S. E. Feedlot cattle pneumonia. The Veterinary Clinics of North America. Food Animal Practice, v. 1, n. 2, p. 289-310, 1985.

YOON, B. N.; CHOI, N. G.; LEE, H. S.; CHO, K. S.; ROH, H. J. Induction of interleukin-8 from nasal epithelial cells during bacterial infection: the role of IL-8 for neutrophil recruitment in chronic rhinosinusitis. Mediators of Inflammation, v. 2010, p. ID 813610 , jan. 2010.

YOUSSEF, S. a; CLARK, M. E.; CASWELL, J. L. Effect of bovine granulocyte colonystimulating factor on the development of pneumonia caused by Mannheimia haemolytica. Veterinary Pathology, v. 41, n. 6, p. 649-57, nov. 2004.

ZECCHINON, L.; FETT, T.; DESMECHT, D. How Mannheimia haemolytica defeats host defence through a kiss of death mechanism. Veterinary Research, v. 36, n. 2, p. 133-156, mar. 2005.

ZEMANS, R. L.; COLGAN, S. P.; DOWNEY, G. P. Transepithelial Migration of Neutrophils: Mechanisms and Implications for Acute Lung Injury. American Journal of Respiratory Cell and Molecular Biology, v. 40, n. 5, p. 519-35, 20 maio 2009.

ZHAO, B.; COLLINS, M. T.; CZUPRYNSKI, C. J. Effects of gamma interferon and nitric oxide on the interaction of Mycobacterium avium subsp. paratuberculosis with bovine monocytes. Infection and Immunity, v. 65, n. 5, p. 1761-1766, 1997. 